\title{
The Panther Springs Creek Site: Cultural Change and Continuity within the Upper Salado Creek Watershed, South-Central Texas
}

Stephen L. Black

Department of Anthropology, Texas State University

Joachim McGraw

Follow this and additional works at: https://scholarworks.sfasu.edu/ita

Part of the American Material Culture Commons, Archaeological Anthropology Commons, Environmental Studies Commons, Other American Studies Commons, Other Arts and Humanities Commons, Other History of Art, Architecture, and Archaeology Commons, and the United States History Commons

Tell us how this article helped you.

This Article is brought to you for free and open access by the Center for Regional Heritage Research at SFA ScholarWorks. It has been accepted for inclusion in Index of Texas Archaeology: Open Access Gray Literature from the Lone Star State by an authorized editor of SFA ScholarWorks. For more information, please contact cdsscholarworks@sfasu.edu. 
The Panther Springs Creek Site: Cultural Change and Continuity within the Upper Salado Creek Watershed, South-Central Texas

\section{Creative Commons License}

(c) (i) (8)

This work is licensed under a Creative Commons Attribution-NonCommercial 4.0 International License 


\section{THE PANTHER SPRINGS CREEK SITE: CULTURAL CHANGE AND CONTINUITY WITHIN THE UPPER SALADO CREEK WATERSHED, SOUTH-CENTRAL TEXAS}

Stephen L. Black and A. Joachim McGraw

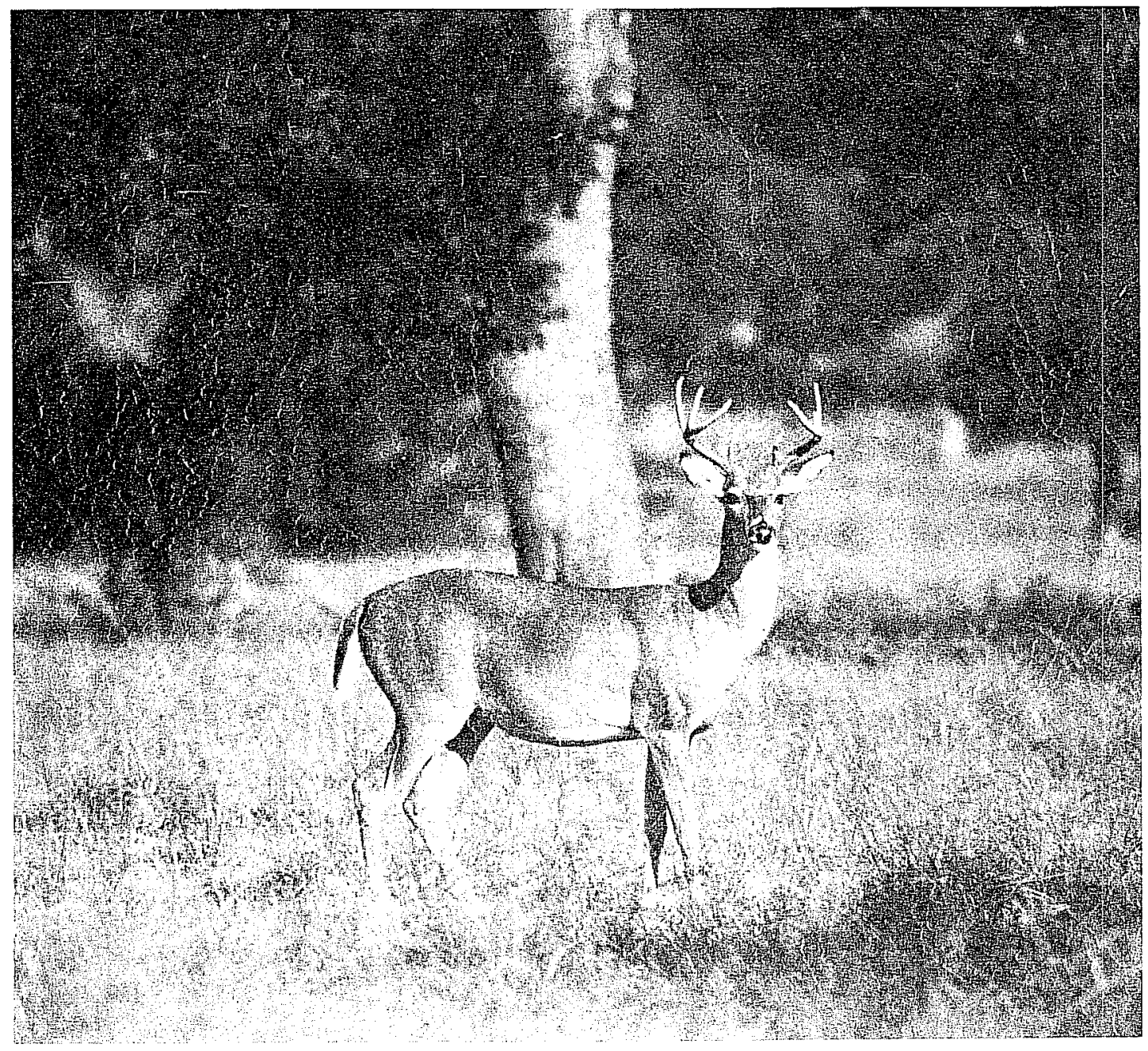

With contributions by Lynn Highley,

Richard C. Hulbert, Jr., Courtenay J. Jones,

Donna D. Lannie, Betty Markey, and Ralph L. Robinson

Center for Archaeological Research

The University of Texas at San Antonio

Archaeological Survey Report, No. 100 
THE PANTHER SPRINGS CREEK SITE:

CULTURAL CHANGE AND CONTINUITY

WITHIN THE UPPER SALADO CREEK

WATERSHED, SOUTH-CENTRAL TEXAS

Stephen L. Black and A. Joachim McGraw

With contributions by Lynn Highley,

Richard C. Hulbert, Jr., Courtenay J. Jones,

Donna D. Lannie, Betty Markey, and Ralph L. Robinson

Cover photograph courtesy of Texas Parks \& Wildiife

Dept., Photography Section. Austin Texas 78744

Center for Archaeological Research The University of Texas at San Antonio

Archaeological Survey Report, No. 100

1985 
Submitted in ful $1 \mathrm{fil} 1 \mathrm{ment}$ of the terms of Contract C3561(78) between the United States Department of the Interior, National Park Service, Rocky Mountain Regional Office, Denvers and the Center for Archaeological Research. The University of Texas at San Antonio.

A 1 ist of pub 1 ications offered by the Center for Archaeological Research can be obtained by sending $\$ 1.00$ to the Center for Archaeological Research. The University of Texas at San Antonio, San Antonio, Texas 78285. 
LIST OF FIGURES ........................... i ...

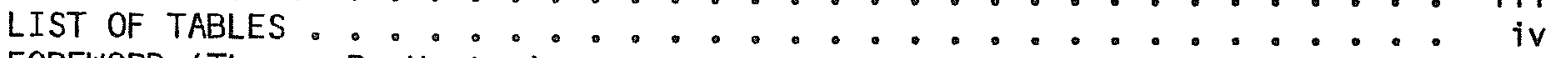

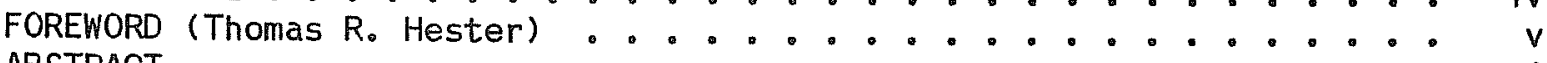

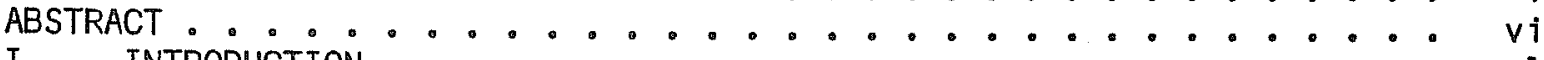

I. INTRODUCTION . . . . . . . . . . . . . . . . . . . . . 1

Previous Site Investigations . . . . . . . . . . . . . 2

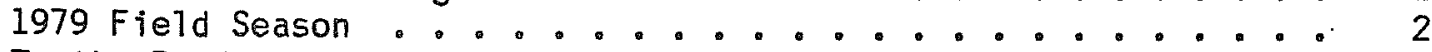

To the Reader ......................... 4

II. RESEARCH GOALS AND STRATEGIES

General Approach to the 1979 Field Season . . . . . . . . . 6

Site-Specific Problems Recognized Prior to Field Work . . . . . 6

Site-Specific Problems Recognized During Field Season ...... 7

Additional Research Goals ............... 8

III. METHODOLOGY ......................... 8

Field Methodology ................... 8

Laboratory Methodology ...................... 28

IV. ARCHAEOLOGICAL BACKGROUND ................... . 31

Previous Research ..................... 31

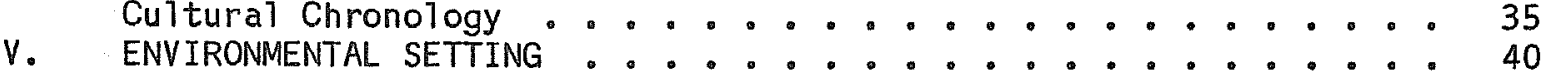

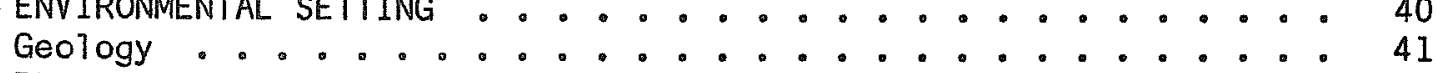

Physiography ..................... 42

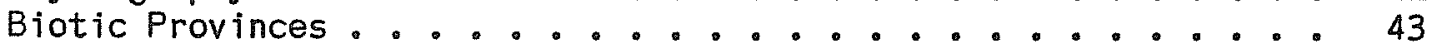

Hydrology ...................... . . . 44 4

Climate ....................... 46

Paleoenvironment ....................... 47

Topographic Setting ................... 49

Geomorphology and Soils .................. 49

VI. MATERIAL CULTURE ................... 55

Lithic Materials ................... 55

Lithic Raw Materials ............ 57

Heat Treatment of Chert .................. 60

Chipped Stone........................ 61

Cores (C) ................ 61

Unmodified Lithic Debitage............ . . 66

Modified Lithic Debitage ............. 73

Thick Bifaces (TK) .............. . . 75

Thin Bifaces (TN) ............... 82

Projectile Points ..... . . . . . . . 95

Distally Beveled Tools (DB) . . . . . . . . 136

Perforators (P) ................ 156

Unifaces .................... 160

Nonchipped Modified Stone . . . . . . . . . . . 167

Battered Stone ................ 167

Ground and Pecked Stone ............. 170

Incised and Abraded Stone ............ 175

Polished Stone ............... 180

Mineral Pigments . . . . . . . . . . . . 183

Ceramics . . . . . . . . . . . . . . . . . . 184

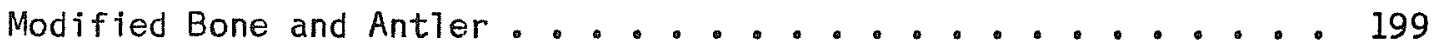


VII. SPECIAL STUDIES .................... 209

Vertebrate Faunat Remains ................ 209

Botanical Analysis.................. 215

Flotation Methodology .................. 219

Soils Chemistry ........................ 223

Radjocarbon Dates .................... 237

VIII. EXCAVATION AREA DESCRIPTIONS AND INTERPRETATIONS . . . . . . 239

IX. SITE OVERVIEW: SUMMARY AND INTERPRETATIONS . . . . . . . 271

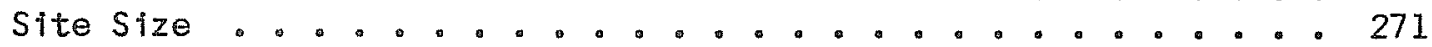

Cultural Component Summaries.......... 272

Local Period 5 Component .............. 273

Local Period 6 Component . . . . . . . . . 276

Local Period 7 Component ............. . 279

Local Period 8 Component ............... 280

Local Period 9 Component ............... 283

Local Periods 10 and 11 Components .......... 285

The Importance of White-Tailed Deer at 41 BX $228 \ldots 288$

X. SITE 41 BX 228 AS A BURNED ROCK MIDDEN SITE . . . . . . . . 290

The Central Texas Burned Rock Midden . . . . . . . . . . . 290

Burned Rock Midden Data from 41 BX 228 . . . . . . . . . 293

Soll Sampling Results ................. 297

Possible Grinding Boulder Associations . . . . . . . . 298

Volumetrics........................ 299

Summary and Interpretations................... 299

$X I$. AN OVERVIEW OF THE PREHISTORY OF THE UPPER SALADO CREEK WATERSHED 302

Environmental Background................. 303

Paleoenvironmental Background ................ . 303

A Summary of Prehistoric Settlement Data in Bexar County . . . . 306

A Prel iminary Statistical Analysis of Physical Site

Characteristics .................. 312

The Upper Salado Creek Watershed and Its Integration Into a

Cultural-Geographical Unit ............. 318

Chronological Sequence of the Upper Salado Creek Watershed . . . 321

Summary ......................... 326

XII. SITE 41 BX 228 WITHIN THE PANTHER SPRINGS AND SALADO CREEKS

CONFLUENCE OCCUPATION ZONE .................................. 336

XIII. SITE 41 BX 228 AS A CASUALTY OF SUBURBAN DEVELOPMENT . . . . . . . 330

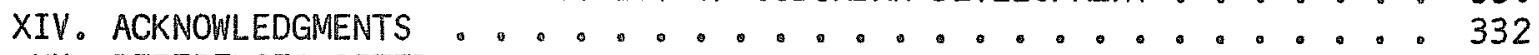

XV. REFERENCES CITED ..................... 335

APPENDIX I. PRELIMINARY BIOSILICA ANALYSIS OF THE PANTHER SPRINGS

CREEK SITE, 41 BX 228, BEXAR COUNTY, TEXAS

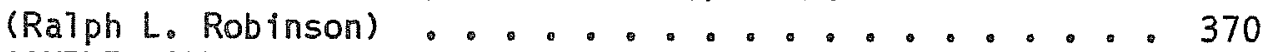

APPENDIX II. SAMPLE FORMS . . . . . . . . . . . . . . . . . 375

APPENDIX III. GLOSSARY OF LITHIC TERMS (Courtenay J. Jones) . . . . . 387

APPENDIX IV. LOT NUMBER INDEX . . . . . . . . . . . . . . . 390

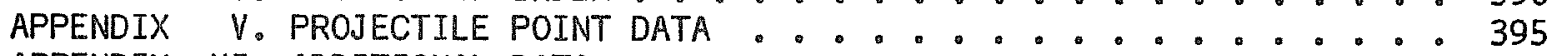

APPENDIX VI。 ADDITIONAL DATA ................. 408 


\section{LIST OF FIGURES}

1. Map of the Panther Springs Creek Site, 41 BX 228 ........ 3

2. Various Views of 41 BX 228 and Vicinity ...................... 13

3. Profile of East Wal1 Backhoe Trench 5............... 18

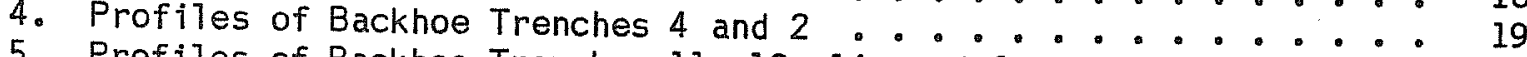

5. Profiles of Backhoe Trenches 11, 12, 14, and $6 . \ldots$. . . . . . . 20

6. Profiles of Backhoe Trenches 10, 10A, 10B, and 10C . . . . . . . 21

7. Profiles of Backhoe Trenches 7, 8, 1, and 9--South End of Site. .22

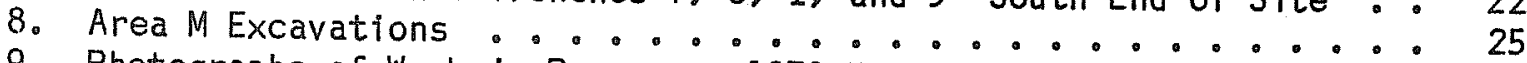

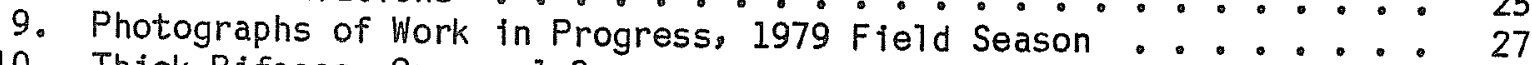

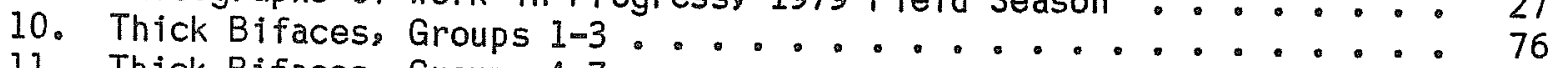

11. Thick Bifaces, Groups $4-7$.

12. Thick Bifaces, Groups $7=9$. . . . . . . . . . . . . . . . 78

13. Thin Bifaces, Groups 1-3

14. Thin Bifaces, Groups $4-7$.

15. Thin Bifaces, Groups 8-11.

16. Thin Bifaces, Groups 11-15

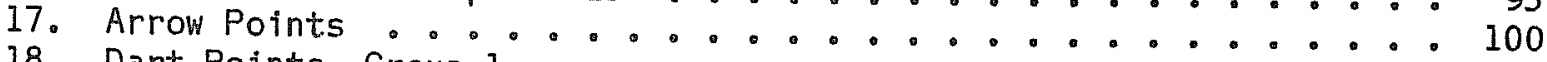

18. Dart Points, Group 1 . . . . . . . . . . . . . . . . . . 104

19. Dart Points, Group 2 . . . . . . . . . . . . . . . . . 110

20. Dart Points, Group 3, Forms 1-5................. . . 114

21. Dart Points, Group 3, Forms 6-11 . . . . . . . . . . . . 118

22. Dart Points, Groups 4 and 5 .................... . . 122

23. Dart Points (Knives?), Group 6 . . . . . . . . . . . ...... . 128

24. "Thinned-Base Early Triangular" Manufacturing and Resharpening

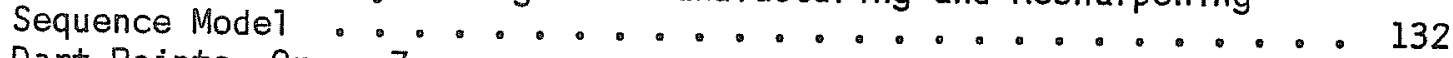

25. Dart Points Group 7 . . . . . . . . . . . . . . . . . 134

26. Dart Points, Group 7 .

27. Guadalupe Tool (Group 2, Form I) and Clear Fork Tool (Group i,

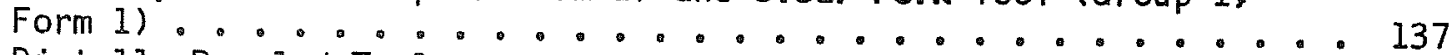

28. Distally Beveled Tools . . . . . . . . . . . . . . . . . . . 141

29. Guadalupe Tool Distribution . . . . . . . . . . . . . . . . . . . 145

30. Guadalupe Tool Manufacturing Sequence, Model No. 1 . . . . . . . 148

31. Guadalupe Tool Manufacturing Sequence, Model No. 2 . . . . . . . 150

32. Distally Beveled Tools, Group 2, Guadalupe Tools . . . . . . . . 152

33. Perforators ....................... 157

34. Uniface Morphology ..................... 161

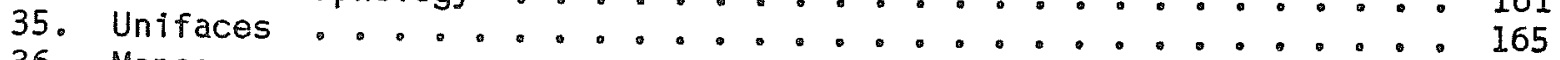

36. Manos ............................. . . . 174

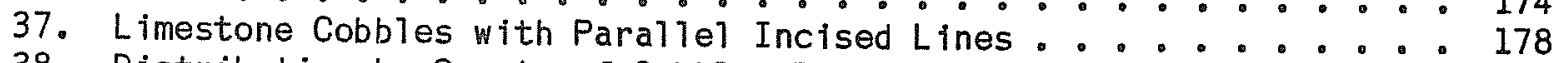

38. Distribution by County of Cobbles Bearing Paraliel Incised Lines $\quad 180$

39. Unusual Polished Stone Artifact................ 181

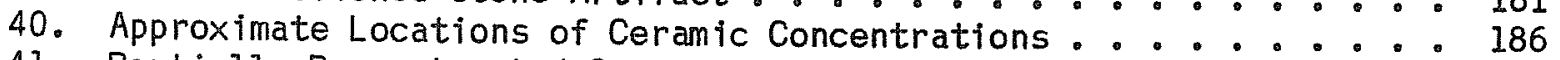

41. Partially Reconstructed Ceramic Vesse1, Group 1 . . . . . . . . . 190

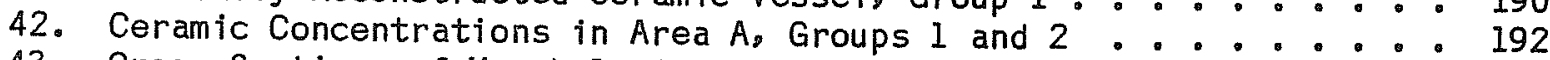

43. Cross Sections of Morphological Ceramic Groups Showing Extent

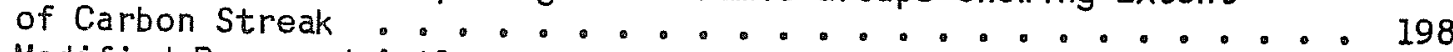

44. Modified Bone and Antler . . . . . . . . . . . . . . . 204

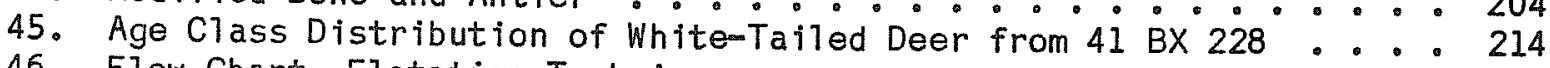

46. Flow Chart, Flotation Techniques ............... 221

47. Vertical Distribution of $\mathrm{pH}$ from Select Area Excavation Profiles $\dot{0}^{\circ} 228$ 
48. Vertical Distributions of Phosphate from Select Excavation Area Profiles and Backhoe Trench Profiles ............ 231

49. Features .......................... 244

50. Burned Rock Feature, Herb's Knol1 .............. 262

51. P1 an Map 3 of Area M, 98.50-98.40 ............ 267

52. P1an Map 4 of Area M, 98.40-98.30 ............ 269

53. Burned Rock Middens, 1979 Excavations ............ 294

54. General Distribution of Drainages and Soils Within Bexar County . 304

55. General Locations of Recorded Archaeological Sites in the Upper

Salado Creek Drainage, Bexar County, Texas . . . . . . . 307

56. Selected Areas for Site Characteristics Analysis, Upper Salado Creek Watershed ................... 314

57. Cluster Analysis of Actual and Potential Site Locations Within the Upper Salado Creek Watershed, Northern Bexar County . . . . 317

58. Archaeological Sites Within the Vicinity of the Confluence and Springs Area of the Salado and Panther Springs Creeks . . . . . 329

59. Substratum Unit Form ................. 376

60. Material Anatysis Form ................. 381

61. Artifact Analysis Form ................. 382

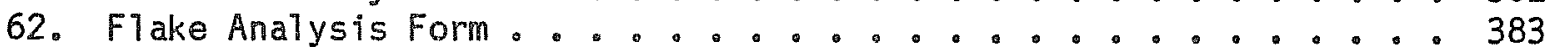

63. Artifact Group Measurements Form ........... 384

64. Flotation Analysis Form ....................... 385

65. Projectile Point Coding Form ............ 386

66. Projectile Point Coding Form ............ 404 


\section{LIST OF TABLES}

1. A Comparison of Regional Cultural Chronologies and

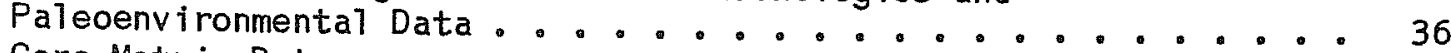

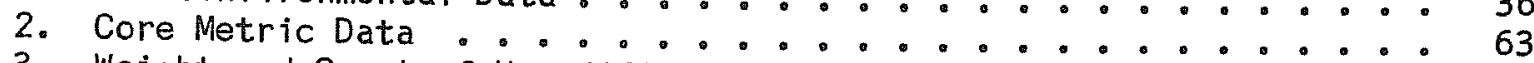

3. Weight and Count of Unmodified Debitage.................

4. Weight and Count of Burned Debitage ........... 70

5. Frequency of Lithic Chunks ..................... 71

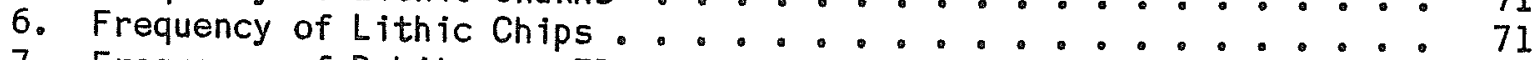

7. Frequency of Debitage: Flakes ............... 72

8. Total Count of Primary, Secondary, and Tertiary Flakes .... 72

9. Flake Frequency Comparisons .............. 74

10. Ratios of Primary, Secondary, and Tertiary Flakes. . . $\quad .74$

11. Percentage of Sma11 Multifacet Platform and the Small Lipped

Platform Flake Categories (Per Unit) ......... 74

12. "Thinned-Base Early Triangular" Biface Attribute Data $\ldots 130$

13. Clear Fork Tool Metric Data . . . . . . . . .... 140

14. Guadalupe Tool Occurrence References by County ........ 144

15. Guadalupe Tool Form 1, Metric Attribute Data . . . . . . . . 153

16. Guadalupe Tool Form 2, Metric Attribute Data..... .154

17. Distal1y Beveled Tools, Group 3, Form 2, Metric Attribute Data : 156

18. Perforator Metric Data .................. 159

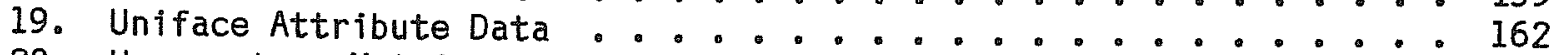

20. Hammerstone Metric and Attribute Data .......... 169

21. Ground and Pecked Stone Attribute Data ........... 171

22. Grinding Boutders, GP:2, Descriptive Data ............. 172

23. Grinding S1abs, GP:3, Descriptive Data $\ldots \ldots 173$

24. Miscellaneous Ground and Pecked Stone, GP:4, Descriptive Data . . 176

25. Attribute Data Incised and Abraded Stone ......... 177

26. Intrasite Spatial Distribution of Ceramic Morphoiogicai Groups : 188

27. Provenience of Modified Bone and Antler, 1977 Excavations . . . 201

28. Provenience of Modified Bone and Antler, 1979 Excavations $\therefore 202$

29. Metric Data for Bone and Antler Artifacts ......... 203

30. Modified Shell Metric Data . . . . . . . . . . 208

31. Nonmammalian Taxa Identified from 41 BX $228 \ldots \ldots 211$

32. Mammalian Taxa Identified from 41 BX $228 \ldots \ldots 211$

33. Types of Deer and Bison Bones Recovered from 41 BX $228 \ldots \ldots 213$

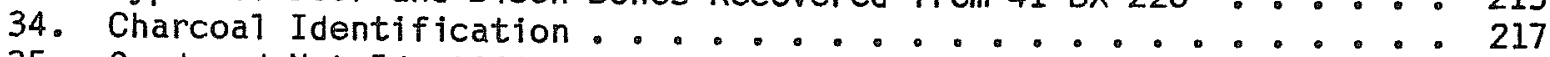

35. Seed and Nut Identification $\ldots \ldots \ldots \ldots 218$

36. Statistical Summary of Soils Chemistry Data .......... 225

37. Soils Chemistry Ana7ysis, Data Set 1 ........... 226

38. Soils Chemistry Analysis, Data Set $2 \ldots 227$

39. Comparison of $\mathrm{pH}$ and Phosphorus in Soil Samples from $41 \mathrm{BX} 1$ and 41 BX $228 \ldots \ldots . \ldots \ldots 233$

40. Camp Bullis, Comparative Soils Data . $\ldots \ldots 234$

41. Summary of Radiocarbon Data, 41 BX $228 \ldots \ldots 238$

42. Artifact Totals by Excavation Area ........... 240

43. Debitage, Burned Rock, and Bone Weight Totals by Excavation Area : 241

44. Vertical Distribution of Select Cultural Materials--Area A . . 243

45. Vertical Distribution of Select Projectile Point Types--Area B $: 248$

46. Vertical Distribution of Select Projectile Point Types--Area C : 252

47. Vertica7 Distribution of Select Artifact Types--Area I . . . 259 
48. Vertical Distribution of Select Artifacts-Area M . . . . . . 265

49. Percentage of Faunal Elements Associated with Local Period 8.

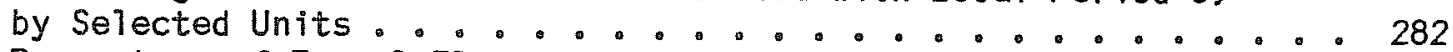

50. Percentage of Faunal Elements Associated with Local Period 9, by Selected Units...................... 284

51. Faunal Elements Associated with Local Periods 10 and 11 , by

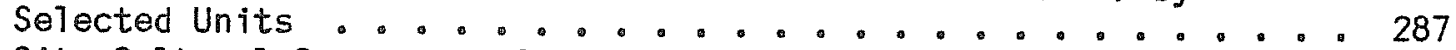

52. Site Cultural Sequences. As Determined by Occurrence of Diagnostic Projectile Points (Percentage) .......... 310

53. General Distributions and Types of Identified Archaeological Sites in the Upper Salado Creek Drainage, Northern Bexar County,

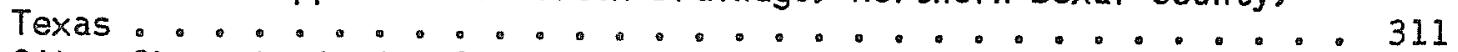

54. Sites Characteristics Along the Upper Salado Creek Drainage, Varimax Rotated Factor Matrix .............. 315

55. Upper Salado Creek Watershed Local Sequence . . . . . . . . . . . 322

56. Selected Radiocarbon Assays of Local Horizon Markers . . . . . . 324

57. Local Cultural Sequence Compared to Inferred, Widespread, Regional Cultural Patterns . . . . . . . . . . 327

58. Percentage Frequencies of Graminae Phytoliths from $41 \mathrm{BX} 228$.

59. Comparison of Percentage Frequencies of Graminae Short Cel1 Phytol iths from Archaeological Sites Containing Festucoid

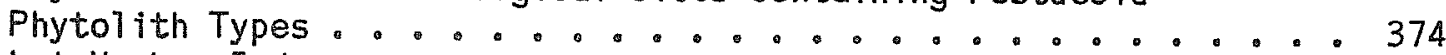

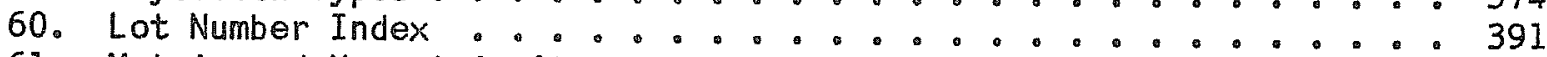

61. Metric and Nonmetric Attribute Data for Projectile Points from

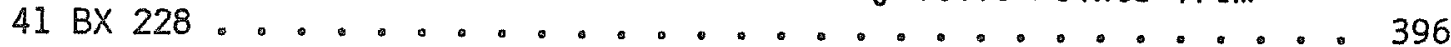

62. Projectile Point Type Codes . . . . . . . . . . . . . . . 402

63. Unit-Level Data...................... 409 


\title{
FOREMORD
}

\author{
"Sweating with the pen is no less important than sweating \\ with the spade."
}

Sir Mortimer Wheeler (1954)

This volume results from archaeological investigations conducted by the Center for Archaeological Research, The University of Texas at San Antonio, under a contract with the Rocky Mountain Regional Office of the National Park Service. The investigations were designed to mitigate the impact caused by the construction of a Soll Conservation Service floodwater retarding structure in the area of site 41 BX 228.

The site was recorded about a dozen years ago by archaeologists from the Texas Historical Commission. Later, in 1974 and 1977, archaeologists from the Center for Archaeological Research conducted 1 imited test excavations. The site has been wel1-known, however, for many years to rel ic-collectors in northern Bexar County. Numerous potholes had been dug at the site over the years, though prior to the 1979 excavations reported here, the San Antonio River Authority (present owners of the property) sought to deter reliccollecting at the site.

Sti11, the site could not be patrolled continuously, and the wooded environs around the site provided "cover" for relic-collecting activities then and up to the present time. Indeed, beyond the scientific merit of the investigations, site $41 \mathrm{BX} 228$ is a particularly distinctive example of site destruction through urban expansion. It is also a frustrating example. The site had been included within the Walker Ranch National Register Historic District in 1977; aside from that federal protection, it was on state-owned property, with protection afforded by the Texas Antiquities Code. We posted numerous warning signs, all totally ignored (and destroyed by the 11 legal diggers). I am convinced that without our excavations in 1979 (during which the relic-collectors stayed away from the site) it would have been destroyed by potholes before the Soil Conservation Service dam (only recently under construction) was built. Fortunately, through the circumstance of National Register status and the federal laws that cover such sites to be destroyed through federal construction activities, the National Park Service was able to award funds for a major excavation effort. More of the checkered history of site $41 \mathrm{BX} 228$ appears in section XII of this present volume.

To return to the archaeological goals of this study, I must note that it was the second of two major excavations conducted, under National Park Service contracts, within the Salado Creek drainage system. One site, 41 BX 300, was dug by Paul Katz for the Center. It is on a tributary on the upper part of the Salado Creek watershed. There, too, a Soil Conservation Service floodwater retarding structure was to be built. In addition, under various contracts with the Soil Conservation Service, staff archaeologists with the Center conducted surveys and test excavations at a number of other floodwater retarding structure sites within the Salado Creek system. Data from all of 
this research, when combined with the work at $41 \mathrm{BX} 228$, serves to provide an integrated picture of the prehistory within a specific drainage system. In many mitigative efforts, we are able to see only a small segment of a region of prehistoric occupation. In the case of the Salado Creek watershed projects, a much broader and more meaningful perspective has been obtained.

The excavations conducted at 41 BX 228 fol lowed a research design prepared by the authors and other Center staff. The approaches, methodologies, and techniques are detailed in this report. A major objective was the study of burned rock middens at the site. A variety of new data on the burned rock midden problem was obtained, and co-author Black has also presented here a comprehensive overview of burned rock midden studies in this region.

This publication results from the hard, and persistent, work of many persons. Authors Stephen Lo Black and A. Joachim McGraw have spent many hours, above and beyond the terms or level of funding of the contract. It was their intent to extract as much from the avallable data as possible and to produce a study that would have lasting value in future archaeological research in southern and central Texas. This, I am convinced, they have done, and done admirably. The staff of the Rocky Mountain Regional Office, National Park Service, Denver, has cooperated with us in many ways, before, during, and after the actual excavations. We appreciate their patience, as we feel this has resulted in a greatly enhanced report. The Center's administrative secretary, Mary Lou E1 1 is has provided vital support and has overseen the entire project. Center editor Sharon Quirk deserves special thanks for her careful and methodical editing of the manuscript... and her willingness to prod the authors along to completion of their work.

Thomas R. Hester Principal Investigator June 24, 1985 


\begin{abstract}
The excavations and subsequent analysis of the Panther Springs Creek site, 41 BX 228, a multicomponent prehistoric open occupation site in south-central Texas, are documented in this report. The investigations at $41 \mathrm{BX} 228$ partialiy mitigate the loss of cultural information caused by looters and potentially by a proposed Soil Conservation Service flood control project. The field investigations carried out in 1979 included mapping, testing, backhoe trenching, and the excavation of several block areas. Large quantities of comparatively wel 1-preserved cultural materials were recovered and analyzed including: 1ithic, ceramic, and bone artifacts as well as faunal and botanical remains. Major aspects of the analysis and of this report include: descriptive, typological, and distributional studies of certain types of artifacts; the spectal studies of faunal, botanical, and solls samples; a study of the burned rock midden phenomena; an examination of the settlement pattern in the upper Salado Creek drainage; and a synthesis emphasizing cultural change and continuity through time in the local cultural manifestations as reflected by the site deposits. The Panther Springs Creek site represents a favored campsite repeatedly revisited over thousands of years by hunting and gathering peoples attracted by the availability of crucial resources such as water, plants, animals, and 1 ithic materials. The site served many functions including that of: a campsite, a 1 ithic procurement area, a flintknapping station, a tool refitting station, a butchering station, a plant processing station, a hunting camp, a gathering camp, and perhaps a social gathering locality. The major problem in interpreting the site is that all of these activities were repeated countless times in an area that had very slow sediment accumulation. Thus, many details of 41 BX 228's long history of prehistoric occupation will never be unraveled.
\end{abstract}

Keywords: Bexar County, prehistoric archaeology, campsite, Archaic, burned rock middens, subsistence, deer hunting, acorn processing, 1 ithic tools, chronology, soils chemistry. 



\section{INTRODUCTION}

During July through December 1979, archaeologists from the Center for Archaeological Research (CAR), The University of Texas at San Antonio (UTSA), investigated a major prehistoric occupation site in the Walker Ranch National Register Historic District of northern Bexar County. Texas. Close cooperation between the CAR-UTSA, the San Antonio River Authority (SARA), the Soil Conservation Service (SCS), and the U.S. Department of the Interior, National Park Service, Rocky Mountain Regional Office (formerly U.S. Department of the Interior. Heritage Conservation and Recreation Service, Interagency Archeological Services-Denver), resulted in the collection of abundant cultural materials and the discovery of significant cultural features at $41 \mathrm{BX} 228$, the Panther Springs Creek site.

Ful1-scale excavation efforts were initiated as a result of 1ong-range plans to construct a floodwater retarding structure across the site area which would destroy or extensively damage the cultural materials and features at the site. A11 work was done under the terms of Contract C3561 (78), dated January 9, 1978, between Dr. Thomas R. Hester, Director, CAR-UTSA, and J ack Rudy, Contracting Officer, U.S. Department of the Interior, Heritage Conservation and Recreation Service. Principal investigator for work at 41 BX 228 was Dr. Thomas R. Hester, with Dr. Joel Gunn as the co-principal investigator. Stephen L. Black and A. Joachim McGraw, both of the CAR staff, were the project archaeologist and assistant project archaeologist, respectively.

The previous 1 imited testing operations, carried out in 1973, 1974, and 1977, revealed that $41 \mathrm{BX} 228$ was an extensive and significant archaeological site. Unfortunately, the abundance of prehistoric artifacts had long attracted many looters and, although the area was monitored for many months by CAR and SARA personne1, damage to the site continued to increase. Even more destruction was anticipated as the site became rapidiy surrounded by new homes, apartment complexes, and streets; site accessibility was increased to both the serious and casual relic collector.

Although funded as a separate mitigation program, the research design of the Panther Springs Creek site was an outgrowth of the problem oriented research followed during the course of excavations at $41 \mathrm{BX} 300$, another 1 arge prehistoric site in the Salado Creek drainage which was mitigated in 1978. Similar problem orientations, methodological approaches, and theoretical perspectives as those used at $41 \mathrm{BX} 300$ were adapted at $41 \mathrm{BX} 228$. This consistent approach was seen as the best strategy for extracting new data on the Salado Creek watershed as a whole. It was felt a synthesis of data from these two sites would contribute much to the regional archaeology of southcentral Texas.

The investigations at $41 \mathrm{BX} 228$ were also designed to recover specific new data about the area's prehistory, for examp 1e: (1) additional radiocarbon sampling at the site would more accurately define the regional chronological framework; (2) the recovery of faunal and botanical materials would help define prehistoric subsistence patterns; (3) the viewing of 41 BX 228 as part of regional cultural phenomena would significantly broaden the body of 
knowledge of prehistoric studies within the drainage; and (4) both diachronic and synchronic cultural variability could be investigated.

\section{PREVIOUS SIIE IMYESTIGATIONS}

Site 41 BX 228 was initially recorded in 1973 by a crew from the Texas Historical Commission while conducting a survey of Walker Ranch. A $1-m^{2}$ test unit was excavated to a depth of $20 \mathrm{~cm}$, producing numerous artifacts and abundant prehistoric cultural refuse. Site recommendations specified additional testing. The site's horizontal extent was estimated at $200 \mathrm{~m}^{2}$ (Hudson, Lynn, and ScurTock 1974).

Site 41 BX 228 received additional testing in 1974 during the CAR-UTSA Salado Creek watershed project. T. C. Kelly expanded the original $1-m^{2}$ unit into a $1.5-\mathrm{m}^{2}$ unit and excavated a second $1.5-\mathrm{m}^{2}$ unit (to depths of 60 and $76 \mathrm{~cm}$. respectively). Once again testing ylelded profuse cultural material. including a number of projectile points and other distinct tool forms (Kelly 1974). Kel1y noted scattered material over a large area of the terrace (810 feet contour) and estimated the site's horizontal extent at $36,000 \mathrm{~m}^{2}$. As a direct consequence of the 1973 and 1974 testing. 41 BX 228 was included in the Walker Ranch National Register Historic District (Hester, ed.o 1974). The site was recommended for major excavation prior to construction of Floodwater Retarding Structure No, 7.

In 1977, the Sol1 Conservation Service provided funding for additional testing at $41 \mathrm{BX} 228$. This testing was conducted by an archaeological field school from The University of Texas at San Antonio (under the direction of Dr. T. R. Hester). The site was partially cleared, gridded, and mapped during the field school. Cleared portions of the site were surface collected using a grid system, with exact locations of diagnostic artifacts recorded. Six $1-m^{2}$ test units were excavated to depths ranging from 50 to $110 \mathrm{~cm}$ in what was considered the main site area. In addition, eight $50-\mathrm{cm}^{2}$ shove 1 tests were placed along several 2-m wide transects cleared through the thick brush in outlying areas of the site. A report submitted by the CAR-UTSA to SCS-Temple (Jaquier et a 1. 1979) details the results of th is testing program. The site was estimated to cover a minimum of $1200 \mathrm{~m}^{2}$ based on the 1977 testing.

\section{FIELD SEASON}

The 1979 field season began during July. Several weeks were spent clearing and reclearing the site by hand, establishing a horizontal grid system and vertical datums, collecting surface materials from $5-\mathrm{m}^{2}$ units in select areas previously uncleared, mapping site topography, and excavating $50-\mathrm{m}^{2}$ shovel tests. Excavation of major units began in August with Areas $A$ and $B$. During September, Areas C, D, and E were opened (Fig. 1). SARA provided a backhoe on September 12 and 13. Sixteen trenches were dug, revealing a much more complex stratigraphy than had been previously recognized. Four discrete burned rock middens (burned 1 imestone accumulations found over much of central and western Texas) were recognized. During October, a number of $1-m^{2}$ 
This page has been

redacted because it

contains restricted

information. 
units were excavated in and around several of the middens. Examination of backhoe trench profiles and backdirt revealed the existence of an Early Archaic component in the southern half of the site. Additional backhoe trenching was conducted October 24 and 25, providing further information on the horizontal extent of several middens. The backhoe was also used to isolate a $4-\mathrm{m}^{2}$ block and to remove much of the overlying relatively sterile, burned rock midden. This block. Area $M$, was located in an area which appeared to contain the thickest deposit of a particular stratigraphic zone, termed the "transition" zone. Early Archaic and occasional 1 anceolate projectile points were consistently observed in trench backdirt piles of the distinctive "transition" zone soils. Area M was subsequently (OctoberDecember) excavated in $2-m^{2}$ units. Excavations were completed by December 7. Much of the time during the final weeks was spent drawing trench profiles, collecting soil column samples, collecting interval soil samples for phosphate analysis, and completing the site map.

Field work was conducted by a CAR-UTSA crew directed by Stephen L. B 1 ack, with A. Joachim McGraw as assistant director. Crew size ranged from four to nine people and was supplemented by volunteers from the Southern Texas Archaeological Association (STAA) and from anthropology classes at UTSA. These volunteers contributed over 400 person hours.

\section{IO THE READER}

Several conventions are followed in this report to avoid confusion and for the sake of consistency. The metric system is used for a 11 measurements except where unavoidable. The following metric abbreviations are used: $\mathrm{mm}=$ millimeter, $\mathrm{cm}=$ centimeter, $\mathrm{m}=$ meter, $\mathrm{km}=\mathrm{kilometer,} \mathrm{cc}=$ cubic

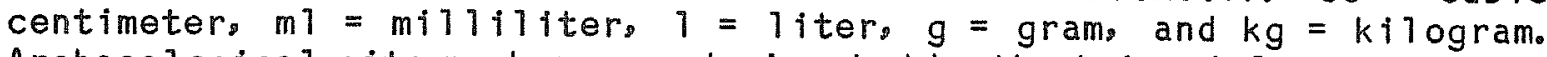
Archaeological site numbers are designated by the trinomial system. For example, 41 BX 228 is the 228 th archaeological site officially recorded in Bexar (BX) County. Texas (the 41 st state). A complete record of each officially recorded archaeological site in Texas is on file at the Texas Archeological Research Laboratory (TARL). TARL is located in Austin at the Balcones Research Center of The University of Texas at Austin. All dates are expressed in the Christian calendar (B.C./A.D.).

A final convention regards the many references to prehistoric chronological periods. As discussed in the Material Culture (Section VI) and An Overview of the Prehistory of the Upper Salado Creek Watershed (Section XI), a number of existing regional chronologies are in part applicable to south-central Texas. None of these were directly suitable to 41 BX 228 without modification. For this reason and others discussed at length in the above-cited sections, a local chronological sequence (Salado Creek Drainage Sequence) involving numbered periods is used throughout the text to refer to specific chronological units. A11 of the local periods have counterparts in one or more of the regional chronologies. For example, Local Period 5 is equivalent in part to the Pre-Archaic (Hester 1980), to the Early Archaic (Story 1980), to the San Geronimo phase (Weir 1976a), and to the San Geronimo and Jarre11 phases (Prewitt 1981). These local periods are further discussed later in this report illustrating the relationship between the various chronologies. 


\section{PREPARATION OF THE REPORT}

This report was written by a number of peop 7 e between 1980 and 1984. Thus, certain inconsistencies in style were unavoidable. Unless otherwise noted in certain subsections of this report, a 11 sections were co-authored by Stephen L. B 1 ack and $A_{\text {. }}$ Joachim McGraw. Black wrote al1 or most of the following sections: I, II, III, VI, and $X$. McGraw wrote An Overview of the Prehistory of the Upper Salado Creek Watershed (section XI), as well as subsections noted in the report.

\section{RESEARCH GOALS AND STRATEGIES}

Due to the limited nature of previous testing, comparatively 1 ittle was known about 41 BX 228 prior to the 1979 field season. Listed below is the pertinent information that was used to plan the June 1979 project at $41 \mathrm{BX} 228$.

1. The upper $30-50 \mathrm{~cm}$ of a large portion of site deposits were being rapidly destroyed by pothunters who had been active there every year since 1975. This area included most of what was considered by previous investigators to be the "main" site area.

2. The site covered an undetermined and poorly delimited area variously estimated at 100-200 $\mathrm{m}^{2}$ (by Hudson and Lynn on the original 1973 survey form), 1200-2000 $\mathrm{m}^{2}$ (Jaquier et a). 1979), and up to $36,000 \mathrm{~m}^{2}$ (Kel $1 \mathrm{y}$ 1974).

3. Previous researchers described 41 BX 228 as a "burned rock midden" (Hudson, Lynn, and Scurlock 1974) or a "concentrated midden" (Jaquier et a1. 1979), with 1ittle additional description of the "midden" composition or configuration.

4. A11 previous investigators agreed that 41 BX 228 contained high densities of 1 ithic debitage, chipped stone tools, burned rock, and fragmented animal bone.

5. Bone preservation was variously described as "generally very poor" (Kelly 1974) to "generally excel lent" (Jaquier et a 1. 1979). Of the species reported from the site, most were larger mammals (primarily deer and bison), with only a few small mammals, rodents, birds, and fish noted.

6. The depth of cultural deposits at $41 \mathrm{BX} 228$ ranged from 50 to $110 \mathrm{~cm}$, with most units reaching "sterile" gravel at less than one meter in depth.

7. Considerab 1e stratigraphic mixing of chronologically diagnostic artifacts was observed by previous investigators, although a general sequence of Late Prehistoric projectile points above Archaic projectile points was noted. 
8. The 1977 UTSA field school encountered several probable cultural features consisting of concentrations of burned rock, 1and snails, and hackberry seeds.

9. A11 previous investigations concluded that 41 BX 228 was a site which merited additional testing or excavation.

\section{GENERAL APPROACH TO THE 1979 FIEED SEASON}

In June 1979, funding for additional work at 41 BX 228 became available. Previous work had identified the general nature of the site but had not been of sufficient scope to adequately or consistently describe many aspects that were necessary to formulate final excavation strategies. The principal investigator (Hester), the project archaeologist (Black), and the assistant project archaeologist (McGraw) reviewed the current information on 41 BX 228 and agreed that preliminary efforts during the 1979 season would be 1 argely exploratory in nature. A general research strategy was formulated which encompassed many of the methodologies and research emphases employed at 41 BX 300. In addition, an unpublished manuscript detailing site-specific research problems and methodologies was prepared (Black, McGraw, and Potter 1979)。

Simply stated, the major goal of the 1979 field work was to systematically excavate one or more open areas, or horizontal excavation units (Hester. Heizer, and Graham 1975:76-78). It was bel jeved that block excavations could yield more information on the spatial relationship of artifacts, faunal remains, and cultural features than the sondage or test pit excavation approach. These units would be located in areas containing the optimal combinations of we11-preserved bone and charcoal, undisturbed cultural stratigraphy, maximum depth of cultural deposits, and intact cultural features. Major aspects of the excavations which would be emphasized were: (1) careful excavation of cultural features; (2) recovery of feature matrix and soil column samples for flotation and chemical assay; (3) recovery of charcoal samples suitable for radiocarbon dating: (4) recovery of faunal materials; and (5) precise vertical and horizontal plotting of potential chronologically diagnostic artifacts. Specific methodologies used in the fleld and laboratory are detailed in the Methodology section (III).

\section{SIIE-SPECIEIC PROBLEMS RECOGNITED PRTOR TO EIELR WORK}

Site size: The extent and configuration of the site's surface and subsurface boundaries needed further definition. Dense vegetation and the 1 imited scope of previous investigations had caused widely varying estimates.

Eaunal remains: The quality of bone preservation at 41 BX 228 was uncertain. In addition, small mammals, turtles, fish, and reptiles were infrequently mentioned in early identification lists (Jaquier et a 1. 1979:Table 2). Possible explanations for this absence included differential preservation in some site areas and in different vertical strata; sampling error, especially due to 1/4-inch mesh screening; or preferential selection of larger species. 
Yertical displacement: In some cases, projectile points known to date from different time periods were found at similar depths. Root activity and burrowing by various animals have been known to cause vertical displacement, but the extent to which the cultural stratigraphy had been disrupted was unknown.

Nature of burned rock accumulations: Descriptions of the burned rock middens at 41 BX 228 were 1 imited. Further examination of the nature of the middens and the process of accumulation was necessary.

Intensity of occupation at the site: The "Positive Sedimentation Hypothesis" proposed by the 41 BX 300 research design (Hester, Gunn, and Katz 1977) suggests that periods of rapid sedimentation at 41 BX 228 were associated with higher levels of human occupation. Unfortunately, this hypothes is is difficult to test due to problems in measuring the rate of sediment accumulation, in measuring the intensity of human activity, and in determining specific units of time with which these measurements could be compared. However, it could be possible to make rough comparisons between distinct time or cultural periods.

\section{SIIE-SPECIEIC PROBLEMS RECOGNIZED DURING_FIELD SEASON}

During the course of the 1979 field season, additional problems and questions about various aspects of 41 BX 228 were recognized. These problems ( 1 isted below) were never formally enumerated except in the daily field journal and in discussion with the principal investigator, but they were addressed by changes in excavation strategy.

Horizontal complexity: While some content variation in the cultural deposits across the horizontal extent of the site was expected, shovel testing and initial excavation units revealed considerably more variation than had been anticipated. Due to the 1 arge size of the site and to the time constraints on the project, it was decided that backhoe trenching could best define the nature of site deposits.

Burned rock midden definition: Backhoe trenching revealed at least four distinct burned rock middens at $41 \mathrm{BX} 228$. However, the size, shape, density, and character of fill seemed to vary from midden to midden. Additional backhoe trenching was conducted 7 ater in the field season to examine the nature of these differences and define periods of accumulation.

Earliest components: Backhoe trenching al so revealed evidence of earlier components at the site than were inftially expected. Lanceolate points simflar to Late Paleo-Indian artifacts, as wel1 as C1ear Fork tools, Guadalupe tools, and various expanding stem points considered diagnostic of the Pre-Archaic (Sol1berger and Hester 1972), were found at the southern end of the site. Excavations at the north end of the site, however, did not produce such material. It was unknown whether this was an in situ isolated component or whether cultural material extended into the gravels previously considered sterile. Additional excavations were conducted in Area $M$ to examine this problem. 
Geomorphological and cultural deposition: Backhoe trenching and excavations also raised a number of questions concerning the formation of the site. Instead of the expected underlying gravel deposits, some areas of the site such as Area A appeared to have been formed on 1 imestone bedrock. Other unanticipated subsurface geomorphological features were cal iche-cemented gravels, a crumbly white substance resembling caliche, and a complex pattern of cross-bedded gravels and apparent runoff channels visible in the deepest backhoe trench (BT 2) profiles. Geomorphologist Glen Evans was consulted to help interpret the formation of underlying terrace deposits.

\section{ADDITLONAL RESEARCH GONS}

The ultimate focus of these problems and questions was the integration of various types of data in order to view 41 BX 228 in two perspectives: (I) as a focus of human activity through time; and (2) as a part of a larger system of prehistoric occupation with in the Salado Creek watershed.

In order to examine human occupation of the site through time, the 1979-1980 41 BX 228 project was directed toward integrating complementary forms of data from various disciplines with excavation methodologies and laboratory analyses. Questions to be answered concerned length and seasonality of occupation, occupational environment, and subsistence patterns. Changes through time in the inhabitants 1 ifeways and possible reasons for these changes $\left(\theta_{0} g_{0}\right.$, response to environnental conditions, population pressures, or a combination of these and other stresses) would a 1 so be investigated. Additionally, the effect of geomorphological conditions on the physical remains of past occupations was an important consideration. In summary, the most important goal of the project was to combine all available 1 ines of evidence to form as detalled a cultural history of the site as possible.

$V$ jewing 41 BX 228 as a portion of a larger pattern of human occupation along the Salado Creek watershed was an additional major goal of the project. It was believed that a synthesis of the Salado Creek watershed prehistory through integration of the results of al1 previous work would put 41 BX 228 in proper perspective. However, the Salado Creek watershed prehistory must be viewed within even larger cultural patterns, the full synthesis of which is beyond the scope of this project.

\section{METHODOLOGY}

\section{EIELD RETHODOLOGY}

A wide variety of field techniques were utllized during the 1979 field season at 41 BX 228. Archaeological texts such as Hester. Heizer, and Graham (1975) and $F 1$ admark (1978) provide descriptions of and references to most of the techniques employed. The field methods used at $41 \mathrm{BX} 228$ are described in some detail to provide the reader with an idea of the problems and difficulties encountered and also to clearly illustrate how the data were obtained. During the course of the project, techniques of recording and excavation were standardized to achieve consistent and comparable results. 
Various factors such as time 7 imitations, variable field conditions, and changing excavation emphases caused certain changes in methodology to be made. These changes are discussed, as they are important in considering and evaluating the resulting data. The field methodology is described in approximate chronological order beginning in June 1979.

\section{CLEARING THE SITE}

In June 1979, the Panther Springs Creek site was an overgrown tangle of whitebrush, mesquite, briar, and grasses woven between 7 ive oak, elm, hackberry, Texas oak, persimmon, soapberry, and other tree species. $A$ 7 imited portion of the site (the "main" site area) had been cleared in summer 1977 by the UTSA field school, but two years later this area was on $7 y$ slightly less dense than the surrounding uncleared area. The only cleared areas of the site were several recent potholes and a few partially visible paths which crossed the site.

In early July, clearing was begun. The most effective brush clearing method employed at the site (with the exception of later backhoe clearing) was the use of a gasol ine-powered "weed eater." An Echo brand (model 302 ADX) "weed eater" equipped with a 10-inch steel brush blade was used to clear most of the site. In comparison to machetes, axes, weed slings, and a small chain saw, the "weed eater" was an incredible time saver. When used properly, the "weed eater" sliced to ground level anything smaller than four inches in diameter. Once the brush was cut, it was hauled off and placed in 1 arge piles around the perimeter of the site. Trees larger than four inches in diameter were left standing whenever possible. Numerous wasp nests and occasional poisonous snakes (rattlesnakes and coral snakes) kept the crew alert. After the brush was cut and removed from a portion of the site, an attachment with heavy nylon 1 ine was used on the Echo to "mow" the grass cover. Leaf rakes were then used to remove the heavy leaf 1 itter which obscured most of the surface. The newly exposed surface was 1 ittered with flakes, tools, and burned rock.

\section{GRID LAYOUT}

As the site was cleared, two of the original horizontal datums, installed along the north-south grid axis in 1977, were located. In spite of this, a new primary datum and grid system were used in 1979 for two reasons: (1) uncertainty over whether the 1977 primary datum had been located; and (2) concern that the site extended further than $100 \mathrm{~m}$ to the south ( 1977 datum $(100 \mathrm{~N} 100$ ). The 1979 primary datum was a one-inch diameter steel stake set in concrete 12 m north of the 1977 "B" datum al ong the same north-south axis. This new primary datum was designated E1000 N1000 (Fig. 1). Use of east and north coordinates allowed plotted artifacts to be assigned the same coordinates as the southwest for any given excavation. An additional back site datum was set in concrete at E1000 N1022.5.

A transit and steel tapes were used to 1 ay out grid points across cleared portions of the site. The E1000 and N1000 grid 1 ines (the north-south and 
east-west axis: respectively) were staked at 5-m intervals using wooden stakes measuring $18 \times 1-5 / 8 \times 3 / 4$ inches. Subsurface burned rock frequent1y made stake placement a difficult job. In addition to the major axis, some areas of the site were staked at 5- or 10-m intervals to facilitate surface collection and future excavations.

\section{SURFACE COLLECTION}

The "main" site area had been surface collected during previous investigations at the site, but during the 1979 clearing operations, heavy artifact concentrations were observed on the surface of the northern portion of the site. The debris was apparent only after a 5- to 15- $\mathrm{cm} 1$ ayer of leaf 1 itter was carefully cleared. Surface collections were made from selected $5-\mathrm{m}^{2}$ units in the northern end of the site ( $F$ ig. $2, e)$. The selection of these collection units was based on location within previously uncleared areas of the site and presence of potentially significant cultural materials. Collection was 7 imited to materials that were chronologically diagnostic: projectile points, identifiable tools, and ceramics. Debitage, cores, and unidentifiable tool fragments were not collected. The collected material was bagged by provenience using the southwest corner coordinates of each $5-\mathrm{m}^{2}$ unit. Random surface collections of isolated artifacts were made at various times during the project.

\section{SHOVEL TESTING}

Most of the testing done in previous investigations at 41 BX 228 was confined to the known "main" site area. By spring 1979, most of this area had been disturbed by pothunting. Shovel testing began July 20. The next seven work days were spent excavating a series of fourteen $50-\mathrm{cm}^{2}$ shovel tests in various areas of the site. The location of the shovel tests was judgmental $1 y$ determined based on the following criteria: (1) concentration in untested areas of the site: (2) desire for a relatively even distribution; (3) avoidance of obvious disturbances such as tree root systems or potholes; and (4) location of a 11 shovel tests adjacent to existing stakes. Shovel tests were placed in the northeast quadrant of a $1-m^{2}$ unit 1 aid out from the grid stakes (southwest corner) to avoid undermining the grid stakes. The shovel tests were excavated by shovel and trowel in $20-\mathrm{cm}$ levels measured from the surface with line levels. Al1 soil was screened through 1/4-inch mesh. Paragraph-style notes were kept for each level.

\section{MAJOR EXCAVATION UNITS}

Upon completion of the shovel testing, it was obvious that the site deposits were varied in depth, extent of preservation, amount of cultural materials, and degree of root disturbance, as well as other factors. As noted in section II, a major research goal was to locate an area having the best combination of conditions to justify the opening of horizontal block excavation units. Three areas of the site appeared to meet most of these criteria and were selected for major excavation blocks (Areas $A, B$, and $C$ ). 
Excavations in Area A were begun in early August. Area A was located on a previously uncleared (as of July 1979) and unnoticed rise at the northern end of the site. Shovel test E1015 N1020 had been excavated on 1 y $20 \mathrm{~cm}$ when a feature containing pottery, burned rock, bone, charcoal, and arrow points was encountered. Ceramics had not been previousiy reported from the site. The presence of ceramics in association with a feature and in an undisturbed area of the site led to the opening of Area A. This excavation area was eventually expanded to a $3 \times 4-m$ block.

Excavations in Area $B$ were begun in mid-August and conducted concurrently with continued excavation in Area A. Area B was located adjacent to the bluff some $12 \mathrm{~m}$ north of the 1973 and 1974 excavation units. The following factors influenced the selection of Area B as a major excavation unit: (1) shovel test E995 N1010 revealed deposits of abundant debitage, bone, charcoal, diagnostic artifacts, and burned rock to at least $60 \mathrm{~cm}$ in depth; (2) this area of the site had been covered by dense whitebrush and briar and appeared 1 ittle disturbed; and (3) location with respect to the bluff was similar to previously tested areas of the site, hence good artifact recovery was expected. Area B was eventual ly expanded into a slightly irregularly shaped excavation block covering $13 \mathrm{~m}^{2}$.

Excavations in Area $C$ were begun on September 1. Area $C$ was located about $1 \mathrm{~m}$ east-northeast of Area $A$ and was excavated to uncover a feature observed 22-28 cm below the surface in shovel test El005 N1025. The feature was a concentration of bone fragments and chert tools. Area $\mathrm{C}$ measured $2 \times 3 \mathrm{~m}$ when completed.

Excavation methodology employed in Areas $A, B$, and $C$, as well as at most 1 ater excavations (exceptions noted), was similar. Arbitrary 10-cm excavation levels were used except for the first level. which varied in thickness. A vertical datum (20d nal1) was established in a large mesquite tree near Area $C$. Secondary backup vertical datums were located in an oak tree near Area $A$ and 1 ater at the southern end of the site. The primary vertical datum was arbitrarily assigned an elevation of $100.00 \mathrm{~m}$ above datum.1 A David White/Patch brand automatic level was used to maintain vertical control. This instrument was found to be far superior to a transit in terms of set up time (approximately two minutes compared to five minutes), accuracy (the automatic level remains on level a 17 day, while a transit, particularly an older instrument, requires frequent releveling), and ease of sighting. The automatic level was set up each morning and a new height of instrument $\left(H_{0} I_{0}\right)$ calculated and entered in a notebook. The $H_{0} I_{\text {. }}$ was checked several times each day to insure accuracy. Stadia readings for even intervals $(10 \mathrm{~cm})$ were calculated and entered for the range of elevations which would be encountered that day. This procedure allowed rapid determination of exact vertical provenience during the day. A11 level floors were checked by instrument. When diagnostic artifacts, features, charcoal samples, or unusual disturbances were uncovered, the vertical provenience was

It should be noted that all specific elevations mentioned in this text are expressed in meters relative to the site vertical datum $(100.0 \mathrm{~m})$. 


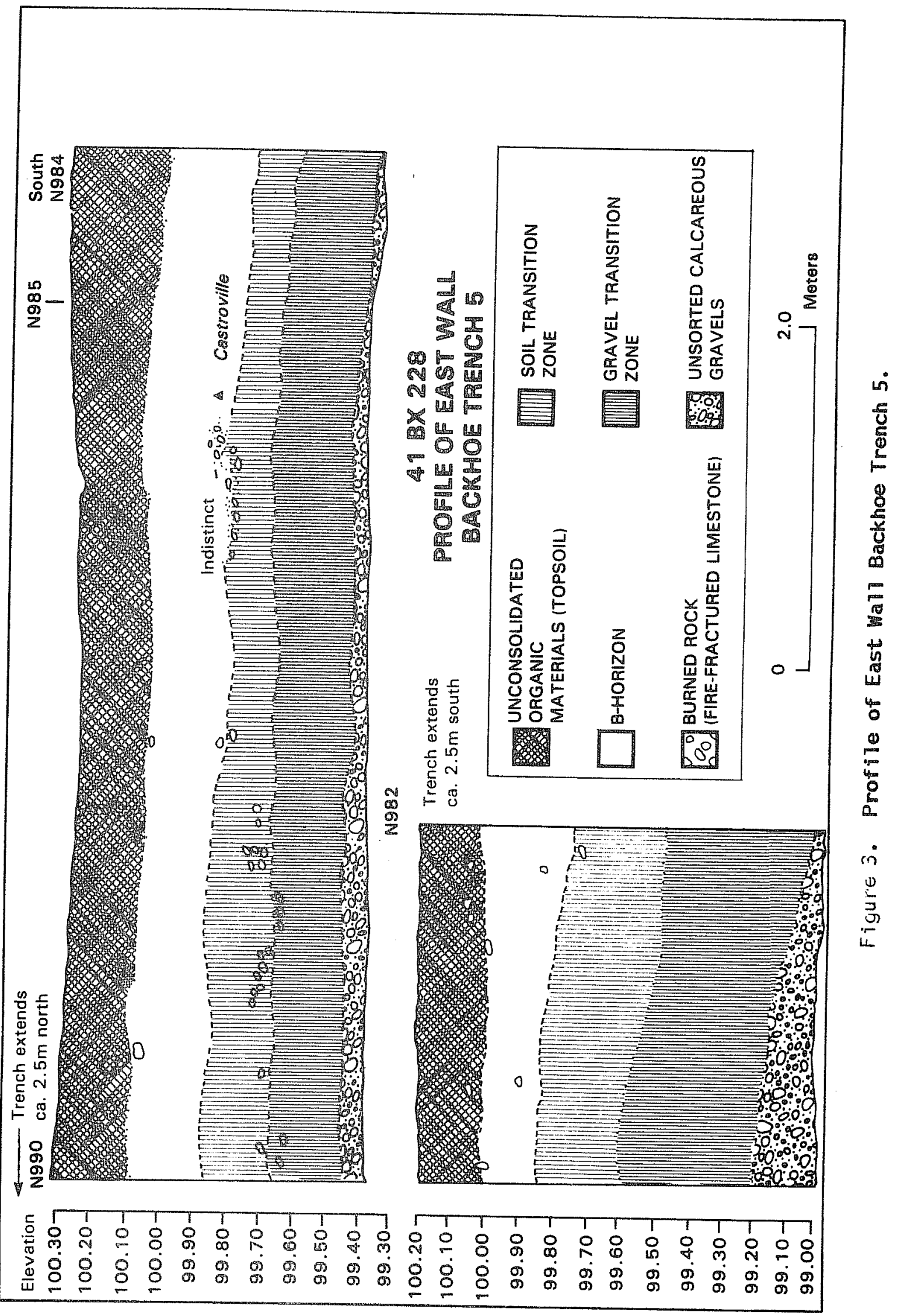




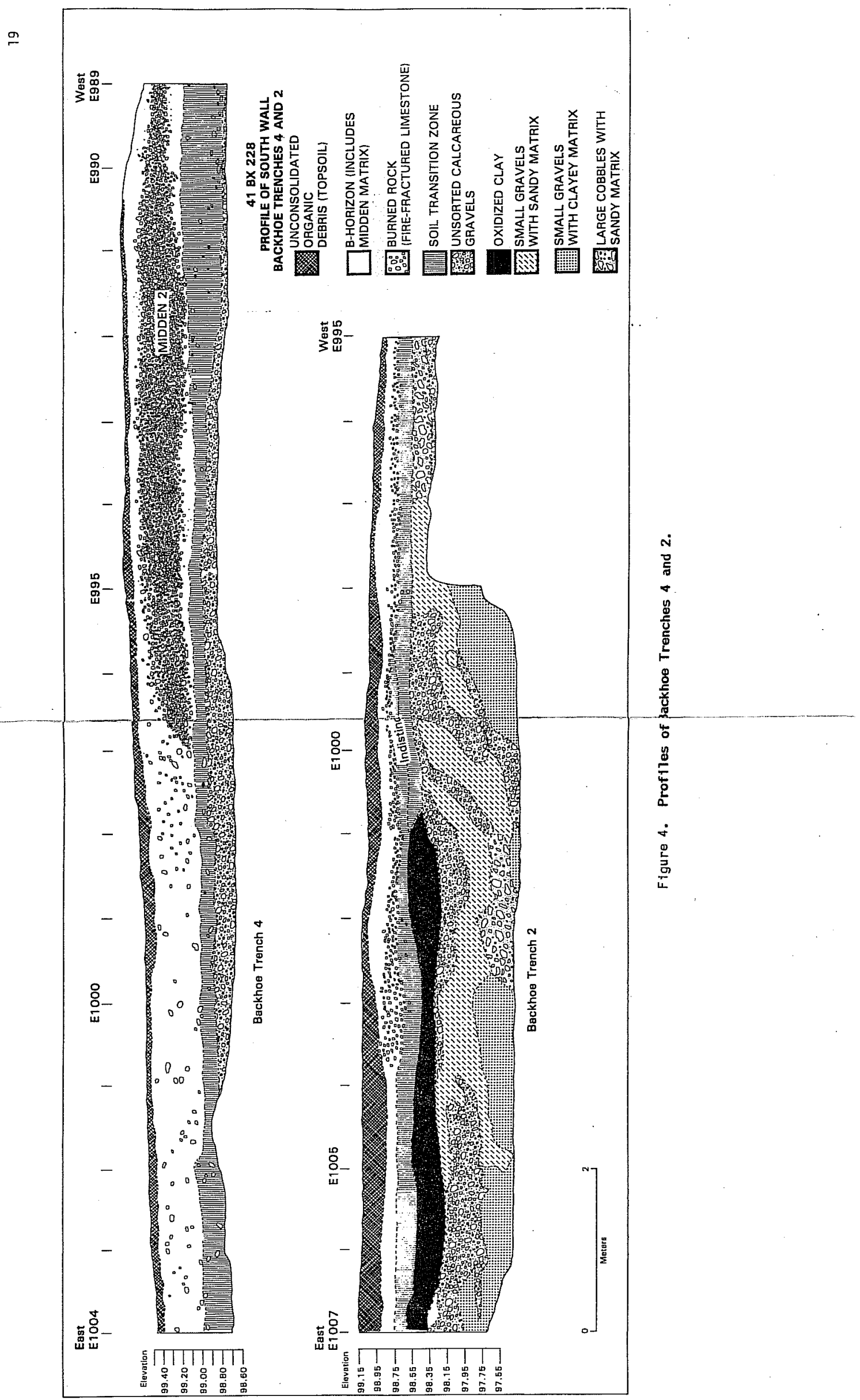





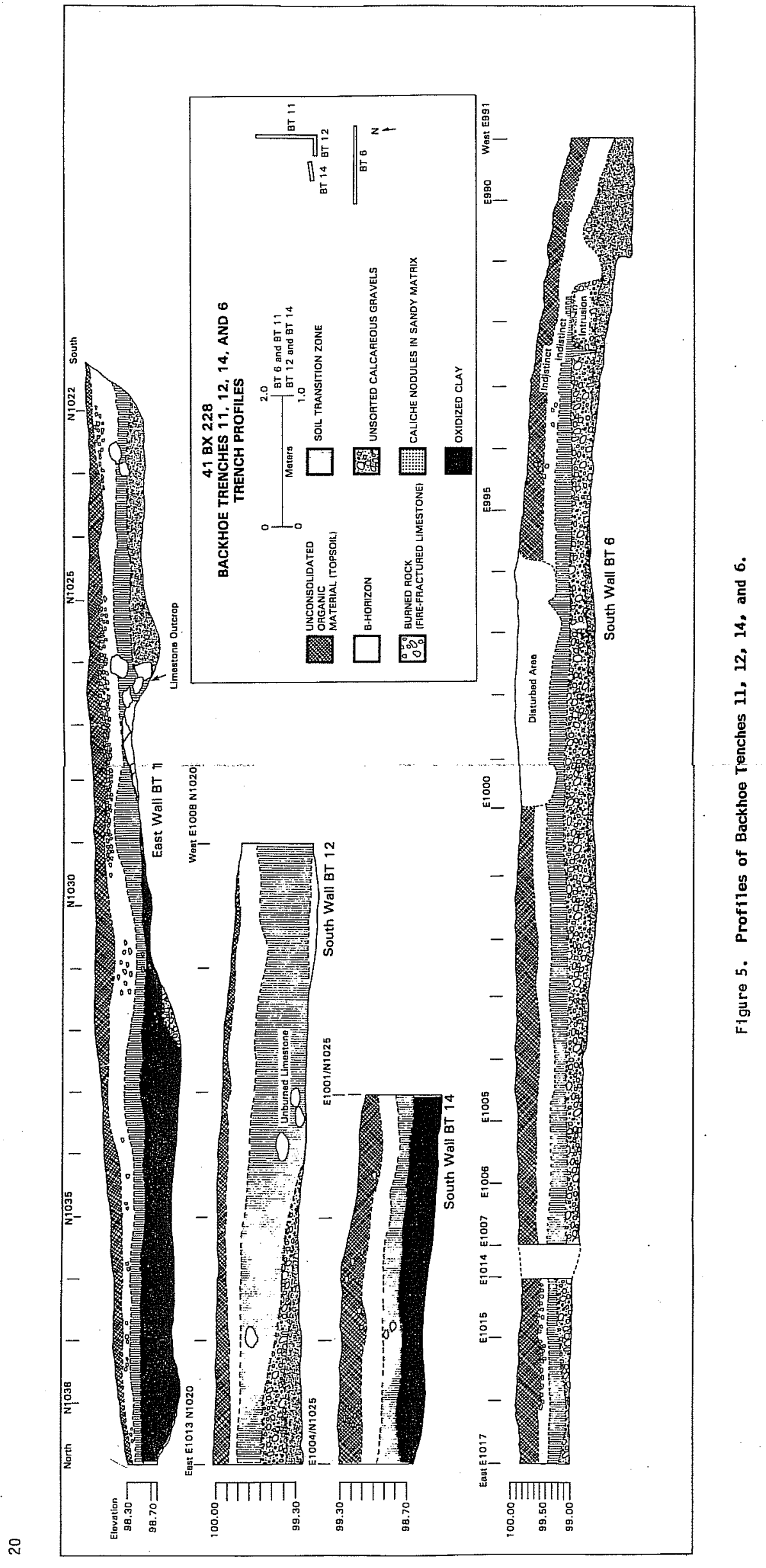





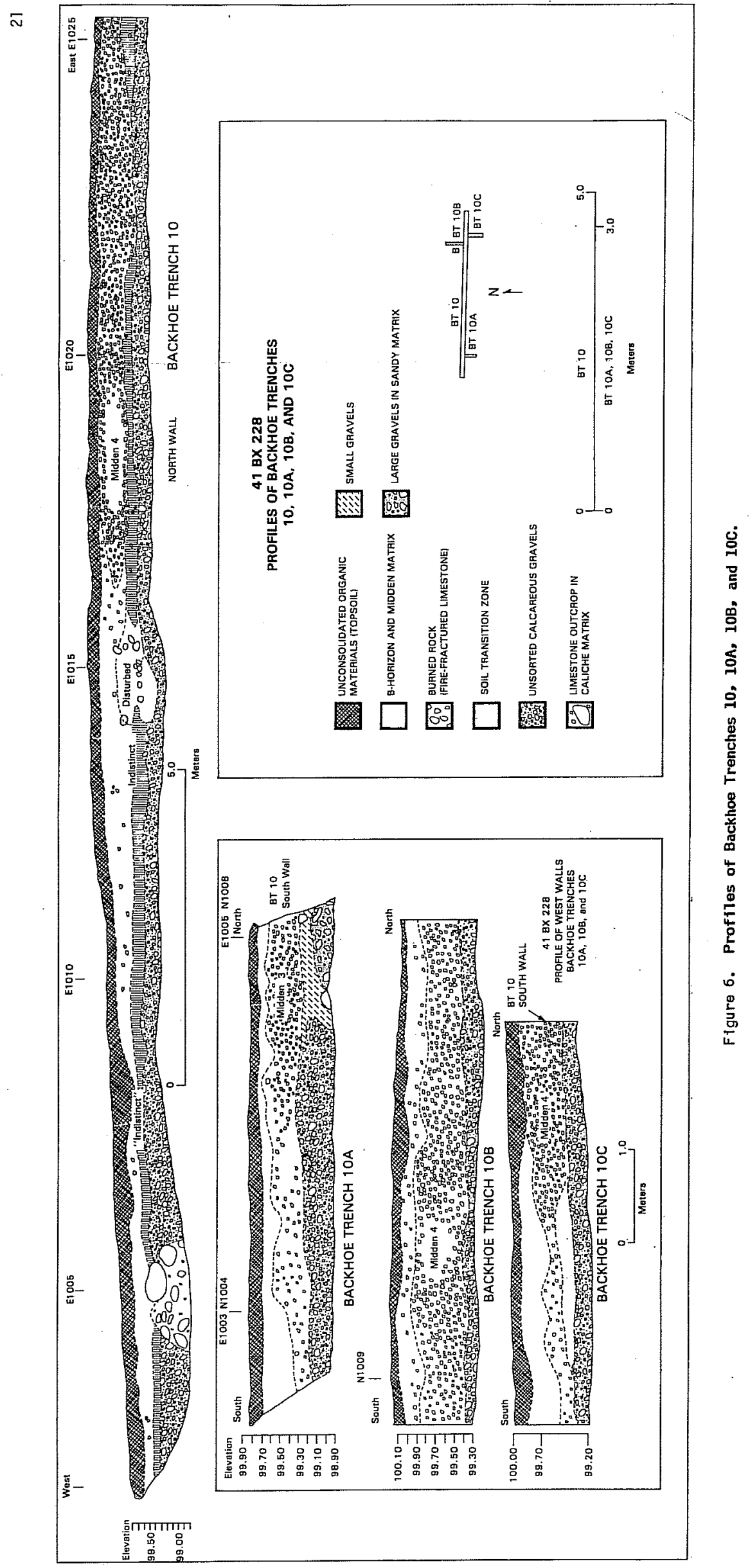





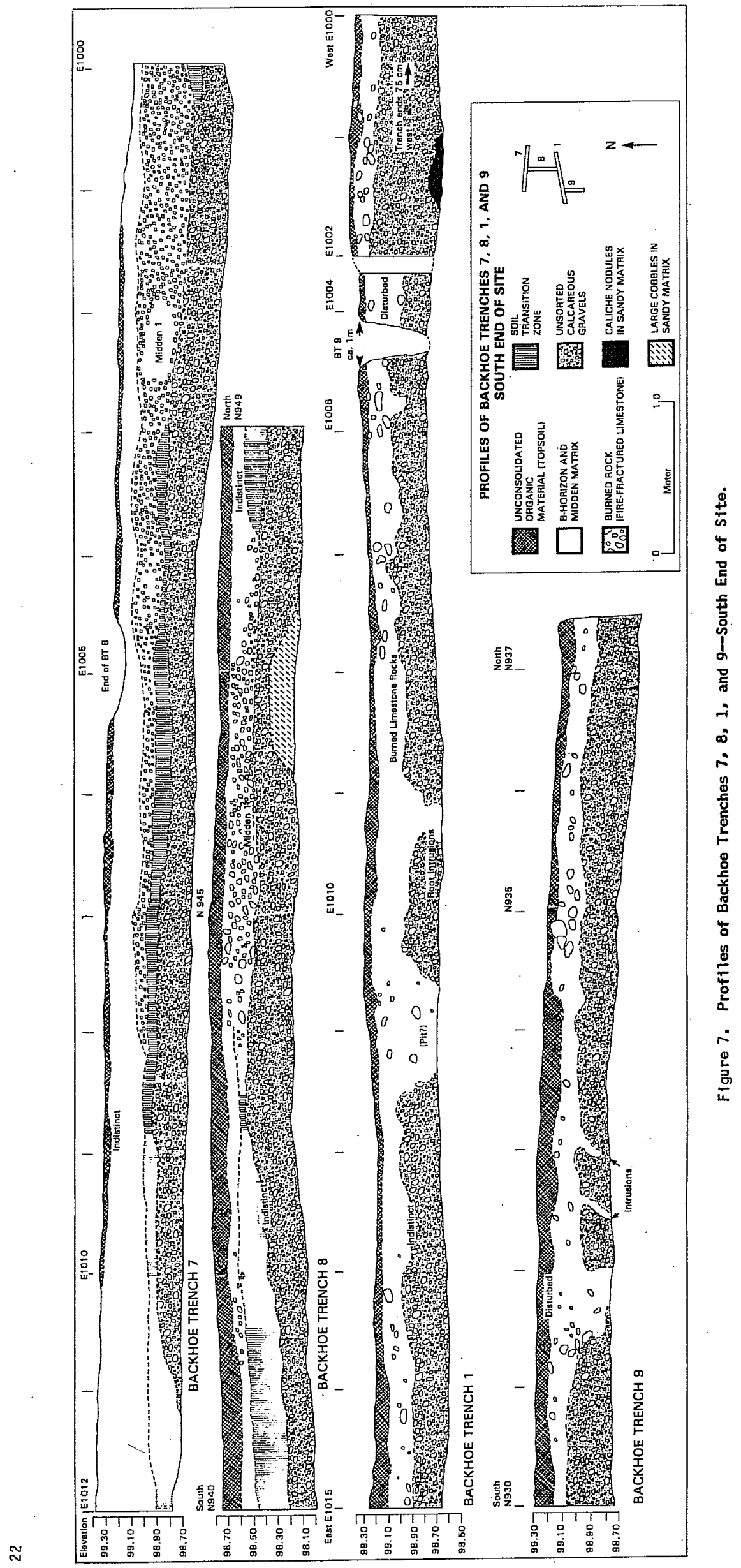





\section{SOIL SAMPLING}

Soil sampling was an important aspect of the field work during the 1979 field season. Soils were coll lected to provide suitable samples for three purposes: flotation, soil chemistry, and phytolith analysis. Each required different amounts of soil and had to be handled carefully to avoid contamination. Three different sampling methodologies were used at 41 BX 228: matrix sampling, column sampling, and interval sampling.

Matrix Sampling: Matrix samples were relatively large soil samples (2000$4000 \mathrm{cc}$ ) taken primarily from cultural feature matrices or fill. The most frequent feature type was burned rock clusters. Matrix samples were taken between the rocks in the most concentrated area of the feature. While most features appeared to have homogeneous soil matrices, a few had two or more distinct fills of varying color and/or texture. Care was taken to collect separate matrix samples from each distinct fill. Matrix samples were also taken in problem areas such as in Area $M$, where soll color or textural changes occurred independent of features. The soil was removed with handcleaned (not chemically cleaned) trowels and placed in heavy-duty plastic tubing. The primary purpose for the collection of matrix samples was for flotation analysis.

Column Sampling: Column sampling consisted of a series of samples taken from a vertical column marked off on an excavation unit or trench wall. Figure 9,b illustrates a crew member removing a sample from column 2, which was located in Area I. A total of six columns was taken, al1 located either in a major excavation block or in trenches adjacent to major excavation blocks. Each column was taken from the wall that the field director felt represented the least disturbed profile in a given area and which could be associated with the best stratigraphic and chronologic control. Four to eight samples were taken from each column. The sample interval varied depending upon the profile; some samples were taken continuously and some at 10-25 cm intervals. This flexibility was necessary to insure that no sample contained soil from more than one stratigraphic zone. The purpose of the column sampling was to provide a comparison of a well-controlled series of vertical samples from important areas of the site and samples collected from various proveniences (e.g.s matrix samples).

Collection of column samples was carefully considered to insure consistency and avoid sample contamination. After the column location was determined. the profile was cut back 5-10 cm with a clean sharp trowel to expose a "fresh" face. Next, level 1 ines were set at even metric intervals with respect to the vertical site datum. Once the cleared profile had been marked by elevation 1 ines, the number and location of samples were determined. A11 samples were taken from rectangular blocks cut into the profile, which usually measured $10 \mathrm{~cm}$ vertical1y by $25-30 \mathrm{~cm}$ horizontal1y. Profile sections with burned rock midden or gravel deposits had very 1 ittle soll matrix and required slightly larger blocks to obtain adequate samples.

The removal of the samples was always done in a specific sequence. Each column was numbered and collected from bottom to top so that loose soil which fell during the sample removal would not contaminate the sample(s) below. In 
Figure 8. Area Excavations.

$a-d$, photographs taken from tree stand looking northwest;

$a_{p}$ backhoe operator begins excavating first short trench perpendicular to BT 4 to isolate Area M excavation block. Crew member uses rake to search backdirt for artifacts;

b. the second short trench has been excavated, and the Area $M$ excavation block is out 1 ined on three sides;

c, backhoe operator begins removing burned rock Midden 2 overburden. Crew members monitor remova1;

d. excavations in Area M just underway. After backhoe removed most of midden overburden crew members shoveled out remainder and set up grid stakes and mapping points;

e, view southwest across Area M excavations. Note in situ exposure of burned rock and artifacts. Also, note Panther Springs Creek in background;

f. view southwest showing automatic level setup and crew members taking level readings. 


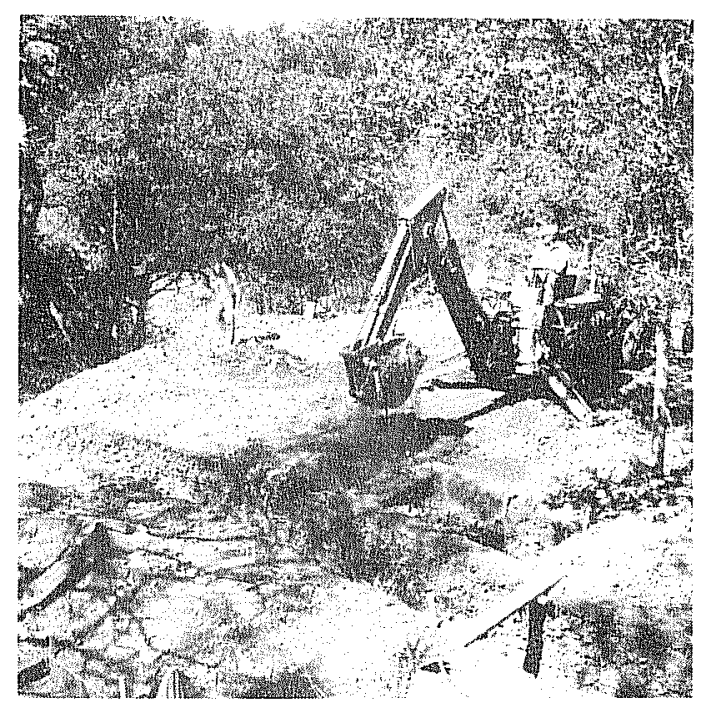

a
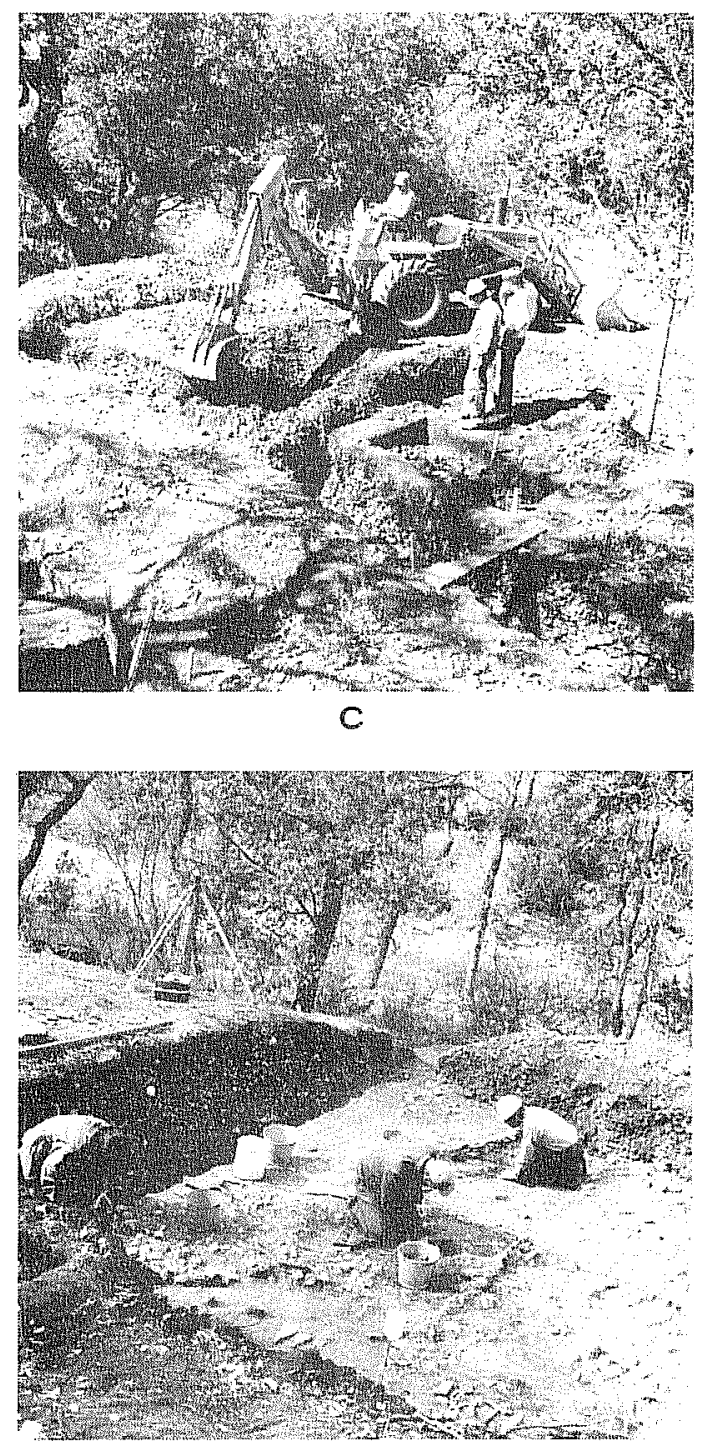

e
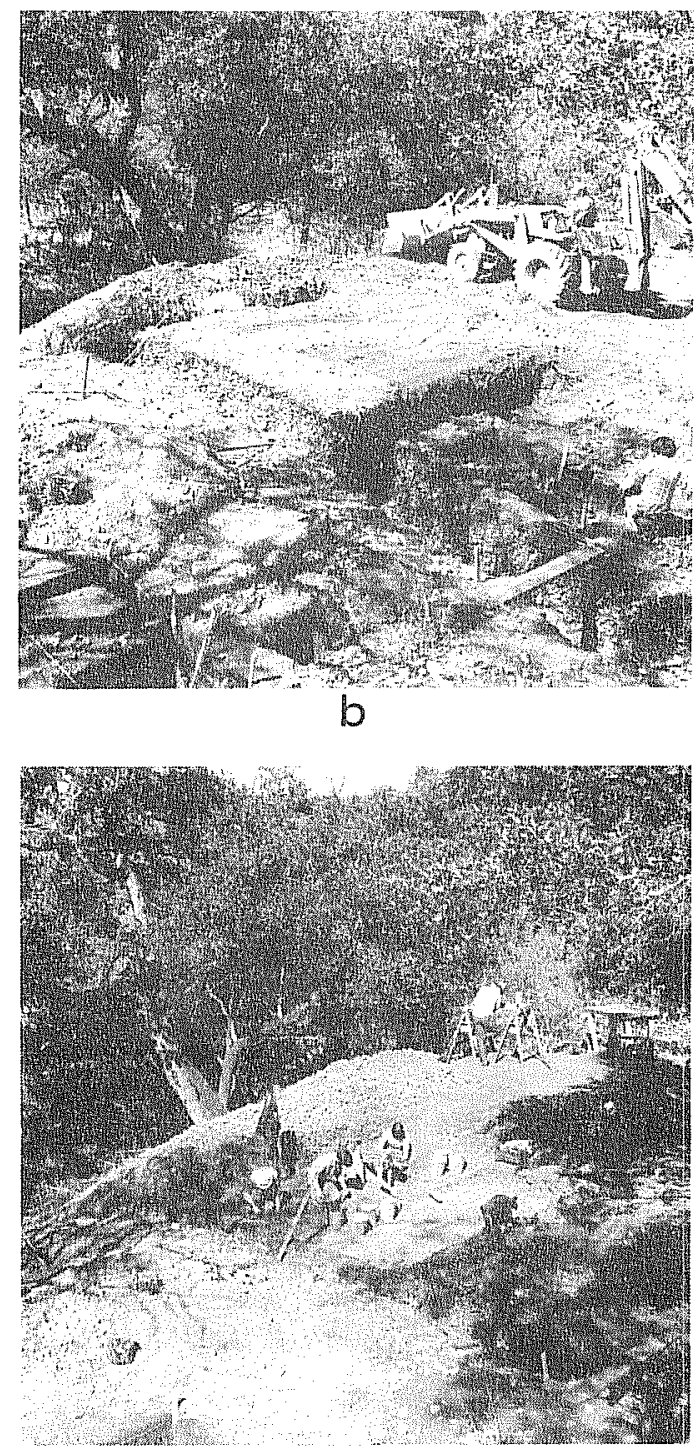

d

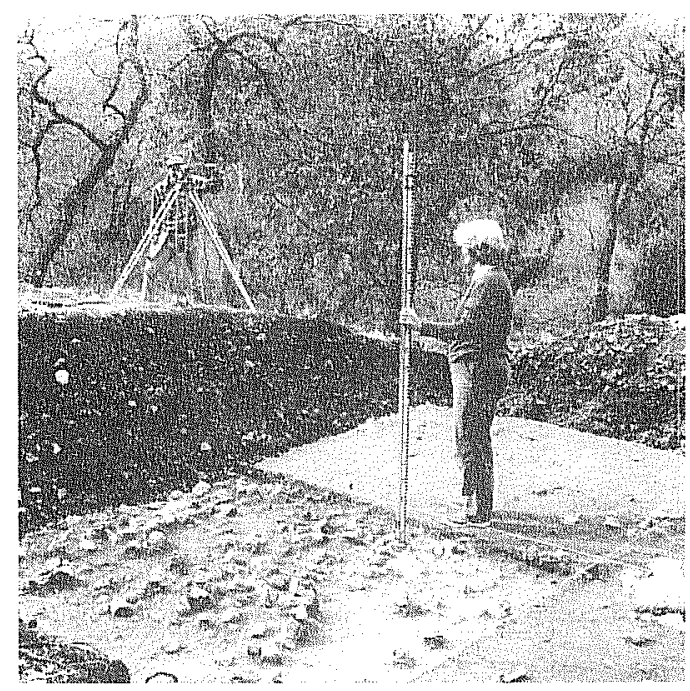


Figure 9. Photographs of Work in Progress, 1979 Field Season.

a. view southeast of Area A excavations. Note dense whitebrush in background;

b. crew member collecting column samples from north wa 11, Area I (column 2):

c, crew member preparing to draw south wall profile of BT 7 . Note burned rock Midden 1 in profile;

d, crew members drawing profile of south wall of BT 4. Note burned rock Midden 2 in profile. Crew member with drawing board is seated on southeast corner of E990 N974. Area M. Crew member with trowel is pointing to contact between burned rock Midden 2 and transition soil 1ayer. 

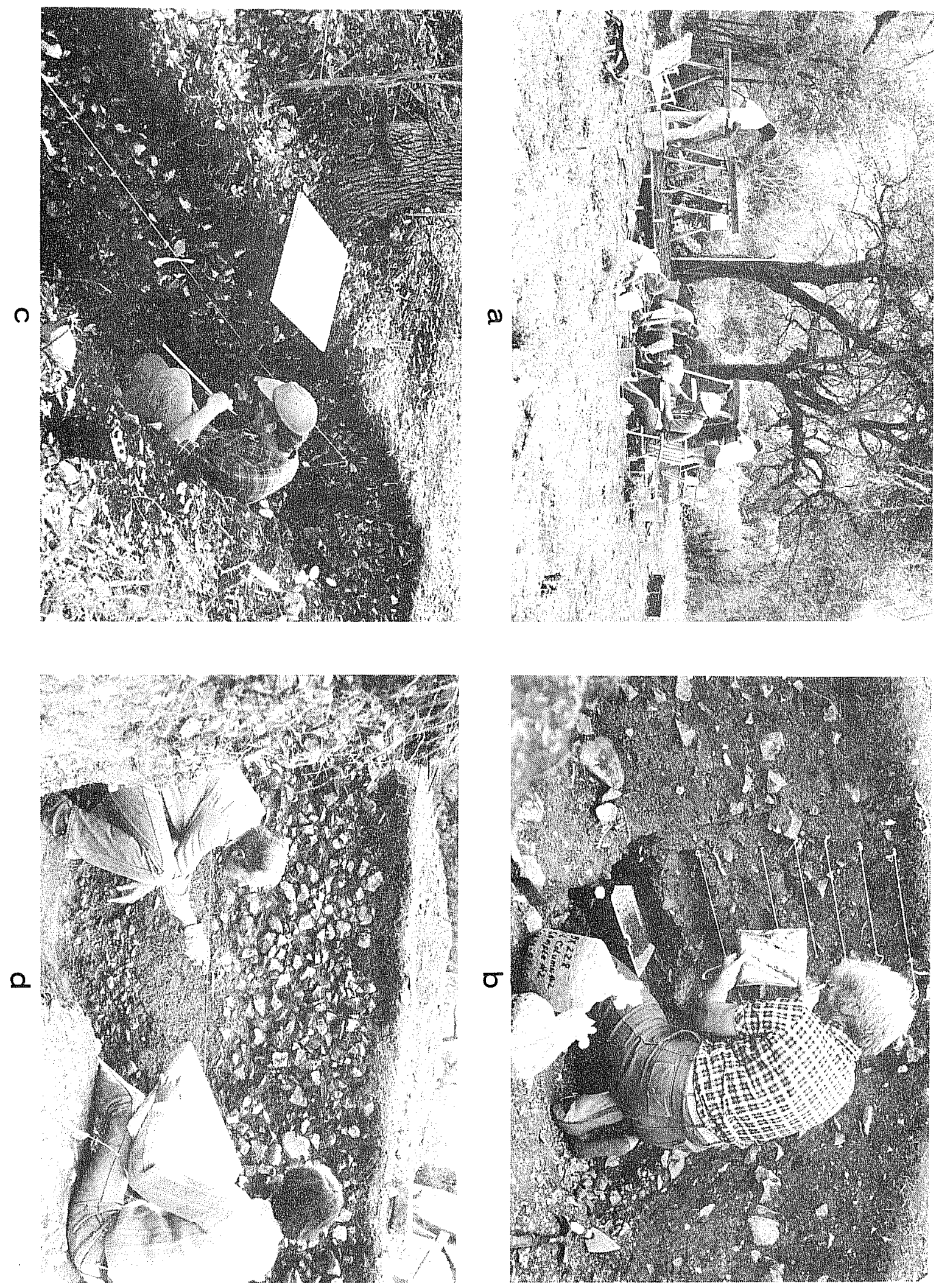
accordance with recommendations from Dr. D. R. Lewis, the project soils chemistry consultant, the collecting trowel (five-inch square trowel) was rinsed prior to use with a diluted $\mathrm{Cl}-\mathrm{HCl}$ solution and then with distilled $\mathrm{H}_{2} \mathrm{O}$ to prevent possible contamination. After the final cleaning of the profile, the collection trowel was recleaned prior to the removal of approximately 30-40 cc of soil for the soils chemistry sample and approximately 100$150 \mathrm{cc}$ of soil for the phytol ith sample. Two crew members took the soil samples: one cut back a small section in the center of the block with the chemically cleaned trowel while the second prepared and labeled collection containers. Soils chemistry and phytolith samples were removed first. Chemically cleaned glass vials (50 cc capacity) were used for all soils chemistry samples. Heavy-duty ziplock bags were used for phytolith samples. Matrix samples were taken next by filling heavy-duty plastic tubing ( $t$ ied to form bags) with approximately 2500-3800 cc of soil. Sample sizes varied somewhat due to the extreme difficulty of removing soils from dry clay-rich compacted solls such as the transition zone soils beneath Midden 2.

Interval Sampling: The backhoe trench profiles provided an ideal opportunity to collect soils chemistry samples at even intervals in order to examine changes in soll chemistry across the site. Of particular interest was the examination of the phosphate levels assoclated with burned rock middens on the site. Three backhoe trenches were chosen for interval samples: BT 4, BT 7, and BT 10, a 11 of which bisected one or more middens. The interval samples were taken horizontally every two meters with three samples taken at each interval. If the interval occurred within a midden, the three samples were taken above, in the middle of, and below the midden. If the interval fell outside a midden. the three samples were spaced evenly-one in the topsoil (A horizon), one in the $B$ horizon, and one in the transition zone (if present) just above the gravel. Sample removal procedure for interval samples was the same as outl ined above for column samp 1 ing, a 1 though on 1 y solls chemistry samples were taken.

\section{LABORATORY METHODOLOGY}

The structure of the 1 aboratory processing and analytical operation was intended to support field operations and to systematically organize and interpret a variety of cultural materials. Laboratory techniques were designed to maximize the potential of data recovery and to broaden the scope of studies through data obtained from related flelds of study. With the exception of some aspects of soils chemistry and flotation techniques, this section will not detall analysis of floral and faunal remains and radiocarbon samples since these were sent to consultants for analysis and are discussed in section VII.

\section{PRELIMINARY PROCESSING OF CULTURAL MATERIALS}

Laboratory processing began with a cross-inventory of collection bags, individual artifacts, and other samples (such as feature matrix, soil chemistry samples, or botanical materials). A11 fleld records and data were also reviewed before inclusion into the 1 aboratory files. All cultural 
debris was assigned a sequential lot number, and index files were established that cross-indexed 1 ot numbers with other control data such as excavation unit (Appendix IV).

Following the initial inventory, perishable materials (e.g.e bone) were either carefully hand washed or placed in an ultrasonic cleaner. After being allowed to dry, materials (when necessary) were coated with a preservative such as polyvinyl acetate (PVA). All other items were sorted into wash and nonwash categories. Washing included cleaning with a phosphate or nonphosphate detergent and water, water alone, or distilled water. Cleaning was done primarily by hand, but an ultrasonic cleaner was also used when necessary. Nonwash materials included residue-related artifacts or special samples that required special treatment before further analysis. If soil and feature matrix samples were to be processed by flotation techniques, either water, distilled water, zinc chloride, or a solution of acetic acid was applied. Flotation techniques required their own control systems which will be discussed in section VII.

After materials were cleaned, artifacts and special samples were catalogued and 1 abeled. Artifacts were 1 abeled with site number, lot number, and if applicable, individual artifact numbers (when artifacts were specifically plotted on unit excavation maps, for examp 1e). The Material Analysis form (Appendix II) was utilized to inventory all cultural debris into a compatible (Statistical Package for the Social Sciences [SPSS]) computer format.

Four main classes of cultural materials were processed: 1 ithics, bone, ceramics, and special samples. A brief discussion of each of these groups is presented. Additional analytical details are in section VI.

\section{LABORATORY PROCESSING OF LITHIC MATERIALS}

The bulk of cultural debris from 41 BX 228 was chert debitage. Processing of 1 ithic materials included a resorting of artifacts into specific material types either as chipped stone tools and their associated debitage or nonchipped modified stone.

Chipped stone tools, usualiy of chert, are characterized by flaking on one or both faces. These artifacts may be further described on the basis of morphology or, when known. function. Tools modified in a consistent and patterned manner were further sorted into stylistic classes broadly defined by the extent of flaking: bifacial or unifacial. Bifacial tools, for the purposes of this report, may be described as tools made on flakes detached from a piece of parent (raw) material. Further flaking has occurred on both inner and outer surfaces to purposefully create a specific shape as well as a particular size (i.e., tool form). Retouch or trimming was distinguished from single edge flaking (termed marginal retouch/trimming) by the extent of the retouch across the shorter axis of the artifact's face (i.e., width). Retouch was classified as either semi-invasive or invasive depending upon whether it extended more or less than two-thirds the distance across the artifact. Unifaces, characterized by on 1 y one modified surface (dorsal or outer), were similarly described. 
Special emphasis was placed upon the definition and description of projectile points. As in many other studies in North America, it is sometimes possible to distinguish chronologically diagnostic dart and arrow points and thereby, by association, to generally date related cultural materials. Projectile points were sorted into broad morphological classes characterized by distinctions in the haft element and the blade. When possible, the artifacts were compared with classifications based on the work of Suhm and Jelks (1962). Each point was then assessed for metric and stylistic variables. Classes, or groups, of points were subdivided into forms (minor variations), and a detailed description of each is presented in the Material Culture section (VI).

By far the largest collection at 41 BX 228 was of unmodified and modified chipped stone debitage. Lithic debitage, for the purposes of this analysis, is described as the waste products resulting from the manufacture, use, or resharpening of siliceous stone tools. Debitage was categorized as remnants of the parent material (cores. core fragments, or irregular chunks) or detached primary, secondary, or tertiary flakes from cores. All flakes possess the remains of an impact platform and bulb of percussion and are classified by the amount of original exterior surface (cortex) on the outer (dorsa 1) flake surface. Those chipped stone fragments that did not have a bu $1 b$ of percussion or platform remnant were classified as chips or chunks.

Special care was taken to identify and separate modified (retouched) debitage from unmodified debitage. While time 7 imitations precluded a detailed analysis of these artifacts, data were tabulated. Intrasite distributions are discussed in the Material Culture section (VI).

As with modified debitage, the large amount of unmodified 7 ithic debris made detailed studies impractical. Nevertheless, four $1=\mathrm{m}^{2}$ test units in Areas $D$, $E$, $F$, and $G$ were analyzed, with $p l a t f o r m$ characteristics and weight as primary distinguishing criteria (see section VI).

\section{LABORATORY PROCESSING OF CERAAICS}

Prehistoric pottery sherds recovered from the site were processed differentiy from other collected materials. A smal1 uncleaned sample of these sherds was inventoried and catalogued and then wrapped in foil and set aside for future studies. All other sherds were washed in an ultrasonic cleaner, dried, and 1abeled. India ink lettering of many small sherds proved difficult, so an abbreviated system was used; sma 11, colored, self-adhesive, circular coding 1 abels (produced by Avery Label Systems. New Jersey) were labeled with the lot number and attached to individual sherds. The sherds were then organized by unit and leve1, and the size ranges of the sherds per unit-level were tabulated. Since a general decrease in the size of sherds from similar groups per locality should be a rough indicator of disturbance (the smaller the sherds, the more crushed and broken the original vesse1), ceramic groups were first sorted into specific size ranges. Ceramic fragments were eventually grouped into categories showing similar morphological characteristics. Both surface and interior sherd characteristics are discussed in section VI. 


\section{LABORATORY PROCESSING OF BONE}

Most of the identified bone collected from the site was separated from other cultural debris for later analysis by a formal consultant. Depending upon the fragility of the sample, bone from excavated units was either hand washed or washed in an ultrasonic cleaner. If necessary, fragments were treated with a preservative such as polyvinyl acetate (PVA). Smaller bone fragments obtained from flotation sampling were often chemically treated with a zinc chloride or acetic acid solution. Since no radiocarbon dating of bone was foreseen, a thorough rinsing and drying was considered adequate treatment during processing operations. The possible utilization of bone as tools was of particular interest to current investigations (see section VI).

\section{LABORATORY PROCESSING OF SPECIAL SAMPLES}

Special samples for laboratory processing included charcoal samples, wood species identification samples, faunal (bone) samples, and soil chemistry samples ( $\mathrm{pH}$, calcium, phosphorus, and organic content). Because of the additional work involved in processing, special sample numbers were used to more easily maintain control. Special sample studies and their analyses are discussed in more detail in section VII.

\section{ARCHAEOLOGICAL BACKGROUND}

The Panther Springs Creek site 1 ies within the southern portion of the archaeological region known as central Texas (Suhm 1960; Weir 1976a; Prewitt 1981). Archaeological sites in south-central Texas often contain a mixture of cultural materials commonly identified with adjacent archaeological regions. Artifact types most characteristic of the lower Pecos region and south Texas as we 11 as central Texas have been found at 41 BX 228 and many other south-central Texas sites. No attempt is made to define an additional archaeological region. However, it is argued that archaeological sites in south-central Texas cannot be evaluated without reference to al1 three adjacent regions. For purposes of discussion, the term "south-central Texas" refers to an area rough 7 y $25 \mathrm{mil} 1$ es either side of the Balcones Escarpment from San Marcos westward to Uvalde. The following section will briefly summarize previous major research efforts in south-central Texas and adjacent (or encompassing) regions; previous research in Bexar County is discussed in greater detail.

\section{PREYIOUS RESEARCH}

\section{REGIONAL BACKGROUND}

Dr. J. E. Pearce (1919, 1932) of The University of Texas at Austin must be recognized as the pioneer of central Texas archaeology. His studies centered around Archaic burned rock midden features common throughout the region. Another influential figure in early regional studies was J. Charles Kelley (1947a, 1947b, 1959), who attempted to apply the Midwestern Taxonomic System 
developed by McKern (1939) to the area's archaeology. Basing his criteria primarily on projectile points, he described Archaic materials in central Texas as related to the Edwards Plateau Aspect. Kelley (1947a, 1947b, 1959) suggested that this aspect was one of several reflections of a much larger cultural phenomenon, the Balcones Phase, which shared characteristics with prehistoric complexes of the southeastern United States and the "Desert Cultures" of the Southwest.

The first summary of Texas archaeology (Suhm, Krieger, and Jelks 1954) provided regional interpretations of various archaeological areas and associated cultural materials. In 1960, Suhm (1960) presented an updated discussion of central Texas archaeology. In this presentation the Archaic Edwards Plateau Aspect and the Late Prehistoric Central Texas Aspect were seen as the most useful terms in defining cultural manifestations, but no consistent subdivisions of these aspects could be described.

Following studies at the Canyon Reservoir, Johnson, Suhm, and Tunnel1 (1962) distinguished Early, Middle, Late, and Transitional Archaic periods within the Edwards Plateau Aspect. After this work, various authors, including Shafer (1963), Sorrows Shafer, and Ross (1967), and Sollberger and Hester (1972), attempted to describe a time span related to a series of "early barbed" points that appeared in the cultural stratigraphy between the terminal $\mathrm{Paleo-Indian}$ period and what was then considered the Early Archaic. Archaelogists today are still attempting to define this and other periodizations within the framework of the central Texas Archaic (see Weir 1976a, 1976b; Mckinney 1981; Prewitt 1981).

The location of $41 \mathrm{BX} 228$ a 1 so falls into the extreme northern margins of what has been defined (Hester 1975a, 1980) as southern Texas. Archaeological research in this region began with Anderson (1932) in the Rio Grande delta and MacNeish (1947) in Far southern Texas and northeastern Mexico. Early regional comparisons were also presented by Kelley (1959). T. N. Campbel1 (1947), and Jackson (1940).

The first major project in south Texas with a systematic design of study involving survey, testing, and excavation was conducted at the falcon Reservoir in Zapata and Starr Counties (Krieger and Hughes 1950; Aveleyra 1951: Hartle and Stephenson 1951; Cason 1952; Jelks 1952, 1953). When Suhm, Krieger, and Jelks (1954) proposed their widely accepted terminology for cultural groups and general temporal associations, the south Texas region was divided into the Coastal area and the Southwest division. Later, MacNeish's (1958) work in northern Tamaulipas described five connected cultural complexes. In 1971, the Archaic stage in southwest Texas was reevaluated by J. P. Nunley (1971). He, unlike his predecessors, suggested a diversified cultural entity throughout the prehistoric past.

During the last decade there has been a tremendous increase in archaeological interest in south Texas, primarily resulting from rapid economic growth in the region and the rise of contract archaeology. The multi-year archaeological program associated with the Choke Canyon Reservoir exemplifies the increased interest in south Texas (Campbe11 and Campbe1 1 1981; Roemer 1981; Thoms, Montgomery, and Portnoy 1981: Ha 11, B1ack, and Graves 1982; and Brown 
et a1. 1982). Despite work in the Choke Canyon Reservoir area and at many other south Texas sites, the prehistoric chronology remains poorly defined (cf. Hester 1980:156). For more thorough discussions of south Texas archaeology the reader is referred to Mallouf, Baskin, and Killen (1977), Hester (1980), and Ha 1 1, B Tack, and Graves (1982).

The lower Pecos archaeological region (also referred to as Trans-Pecos or southwestern Texas) 1 ies some 150 miles west of $41 \mathrm{BX} 228$. The arid environment of this region, combined with the large number of rockshelters and caves along the lower Pecos River and other tributaries of the Rio Grande, has resulted in some of the most remarkable preservation in North America. The pictographs, basketry, textiles, fiber layers, wooden implements, coprolites, and mummified burials have drawn museum collectors, looters, treasure hunters, and archaeologists to the lower Pecos River region for over 60 years. Most of the careful archaeological work in the region was done by various archaeologists from The University of Texas at Austin (cf. Johnson 1964; Sorrow 1968; Dibble and Lorrain 1968; and Col 1 ins 1969). The remarkab le preservation of the often we 11-stratified rocksheiter deposits has provided considerable paleoecological data (cf. Story and Bryant 1966; Bryant 1974; and Williams-Dean 1979). For a recent summary of lower Pecos archaeology, see Shafer and Bryant (1977).

Lower Pecos 1 ithic artifact forms are usually distinct from contemporaneous central Texas 1 ithic forms, al though similarities and co-occurrences are common. Leroy Johnson (1967) compared 1 ithic assemblages from central and southwestern Texas using statistical methods. Johnson argued that, while the two areas shared similarities at certain points in time (for example, the Paleo-Indian period), central and southwestern Texas stood "apart as separate archeological provinces throughout much of their histories" (ibid.:v). He also suggested that, archaeologically speaking, the arid southwestern area of Texas was more culturally stable than the semiwooded area of central Texas.

\section{LOCAL BACKGROUND}

The great majority of the over 500 recorded archaeological sites identified in Bexar County are the result of an intensive program of contract archaeology at the Center for Archaeological Research. The University of Texas at San Antonio. The cumulative result of its efforts in the last nine years has made Bexar County one of the most archaeologically studied areas in Texas. While much of this work has been on a preliminary survey level, continuing programs of testing and excavation at archaeological sites may soon contribute to a preliminary synthesis of data.

The first description of prehistoric sites within the county was presented by Woolford in 1935. He summarized 10 types of sites and associated artifacts, and made general inferences about their ages. Woolford's (1935) perceptive comments are made more significant today because many of the specific site areas he discussed have long since been destroyed. Orchard (1938) continued archaeological research within the county, and in 1954 he reviewed the sites and artifacts from the San Antonio area (Orchard and Campbel1 1954). Early work during this period centered around sites in the 07 mos Basin and San 
Pedro Springs areas, although as early as 1935 Woolford suggested that more extensive, major concentrations of sites existed in the valleys of northern Bexar County (Wool ford 1935).

By the 1960s, Schuetz (1960) had 1isted a number of sites along the Martinez Creek drainage in eastern Bexar County. In addition, Wise (1964) described an upland site in the northeast county area, and several sites along the Salado Creek drainage were identified (see Uecker 1966; Schuetz 1966; Givens 1968). Interest and activity in Bexar County archaeology eventually culminated in an overview of county prehistory by Fawcett (1972). By this time, a wide diversity of prehistoric cultures, sites, and materials had been recognized. Extensive remains of Paleo-Indian materials had been noted in the 01 mos Basin area (Orchard and Campbe11 1954); southwestern pottery sherds related to the Anasazi Pueb 10 II and III sequences (Fawcett 1972) were tentatively identified from 01 mos Park locations; and Hitzfelder (Collins 1970) and Friesenhahn (Graham 1976) Caves had gained national prominence (and controversy) as potential Early Man sites. Investigations at Walker Ranch (Scurlock and Hudson 1973; Hudson, Lynn, and Scurlock 1974) continued to broaden the perspective of the area's archaeology.

Following the growth of contract archaeological services at the CAR-UTSA and the formation of the avocational Southern Texas Archaeological Association, a dichotomy of interest and information gradually widened between northern and southern county areas. As more and more sites were recorded in northwestern and northeastern areas because of expanding federal, 1ocal, and commercial interests (see Gerstle, Kelly, and Assad 1978; McGraw, Valdez, and Cox 1977; MCGraw and Valdez 1978a; Hester, ed.s 1974), the Salado Creek and its tributaries became a major focus of study. Sites of major archaeological significance in northern Bexar County include $41 \mathrm{BX} 22$, the Rogers site; 41 BX 228, the Panther Springs Creek site: 41 BX 300: 41 BX 229, the St. Mary's Ha11 site; $41 \mathrm{BX} 17$; and $41 \mathrm{BX} 271$, the Granberg II site. Additional studies include Smith and McDonald (1975), Brown et. a 1. (1977), McGraw and Valdez (1978b), Katz (n,do), Fox (1977), and Potter (1980).

In contrast to the extensive studies of northern Bexar County, little prehistoric research has been conducted in the southern areas. Oniy recentiy have studies (McGraw 1977: Hester. Mil1er, and North 1978; Valdez 1979; McGraw and Marshal1 1982) begun to investigate the geographically and biotically distinct areas south of San Antonio and its environs.

Continuing and expanding commercial and suburban developments throughout much of the San Antonio and Bexar County area should make the understanding and investigation of $10 \mathrm{ca} 1$ archaeological sites a necessity rather than a casual commitment for both vocational and avocational archaeologists. Site vandalism, relic collecting, and site destruction have increased commensurately withe if not faster than, site identification and recording. More by luck than by design, some of the archaeological sites described by Woolford almost 50 years ago have survived, but given the increasing rate of destruction, many of the recorded Bexar County archaeological sites wi11 not survive another quarter century. 


\section{CULTURAL CHRONOLOGY}

A11 of the recent chronological sequences proposed for south and central Texas recognize four major cultural periods or "stages": the Paleo-Indian, the Archaic, the Late Prehistoric, and the Historic. Subperiods or "phases" have been proposed for each major cultural period 1 argely on the bas is of stratigraphic and chronologic relationships between diagnostic artifact types (usual 1 y projectile points) or assemblages. Table 1 provides a visual comparison of various recent cultural chronologies (Weir 1976a; Story 1980; Hester 1980: and Prewitt 1981) as wel1 as paleoenvironmental or climatic chronologies (Di1 lehay 1974; Gunn and Weir 1976; Graham 1976; Bryant and Shafer 1977; Robinson 1979; Story 1980). The applicability of the regional chronologies to the Salado Creek watershed is discussed in section XI. A brief discussion of the major cultural periods is presented below.

\section{PALEO-INDIAN PERIOD (ca.9000-6000 B.C.)}

The Paleo-Indian period is the earliest substantiated cultural period in Texas, although older cultural remains may exist. The Paleo-Indian period is associated with a changing late Pleistocene environment markedly different from present conditions (Graham 1976; Bryant and Shafer 1977). The PaleoIndian period is usual1y divided into early and 1 ate divisions. The subsistence and settlement patterns of the Early Paleo-Indian cultures are traditional ly thought to have been centered around extinct Pleistocene megafauna or "big game" such as the early species of bison (McDonald 1981) and mammoth. Early Paleo-Indian sites are recognized by the presence of fluted 1 anceolate projectile points such as the Clovis and Folsom types. Late Paleo-Indian occupations are marked by a more diverse group of unfluted 1 anceolate points including the PIainview, Golondrina, Angostura, and Scottsbluff types.

The Early Paleo-Indian culture in south and central Texas is believed to be related to the better known big game hunting tradition of the Great Plains (Hester 1980). Most of the wel1-documented Early Paleo-Indian sites in Texas that are associated with extinct megafauna are located north and west of central Texas in the L 1 ano Estacado and adjacent areas of the southern Plains. The Lubbock Lake site (B1ack, ed. 1974; Johnson and Holliday 1980), Lake Theo (Harrison and Killen 1978), and the Rex Rodgers site (Hughes and Wi 1 ley 1978) are among the best examples of Plains-related Early Paleo-Indian occupations in Texas. The closest Early Paleo-Indian site to $41 \mathrm{BX} 228$ possessing unquestionable associations with extinct megafauna is Bonfire Shelter (Dibble and Lorrain 1968), a bison kill (jump) site in the lower Pecos region. In central and south Texas the best candidates for Early Paleo-Indian-extinct fauna associations are al 1 clouded by controversy and/or incomp letely published finds. These include Kincaid Rockshelter (Hester 1980:142), the Levi site (A Iexander 1963), and the Berclair terrace site (Sel 1ards 1940).

Later Paleo-Indian sites are much more numerous in south and central Texas than Early $\mathrm{Pa}$ leo-Indian localities, although both are usually identified from only surface-collected artifacts. Within the past decade at least four Late 
TABLE 1. A COMPARISON OF REGIONAL CULTURAL CHRONOLOGIES AND PALEOENVIRONMENTAL DATA (modified from Katz n.d.)

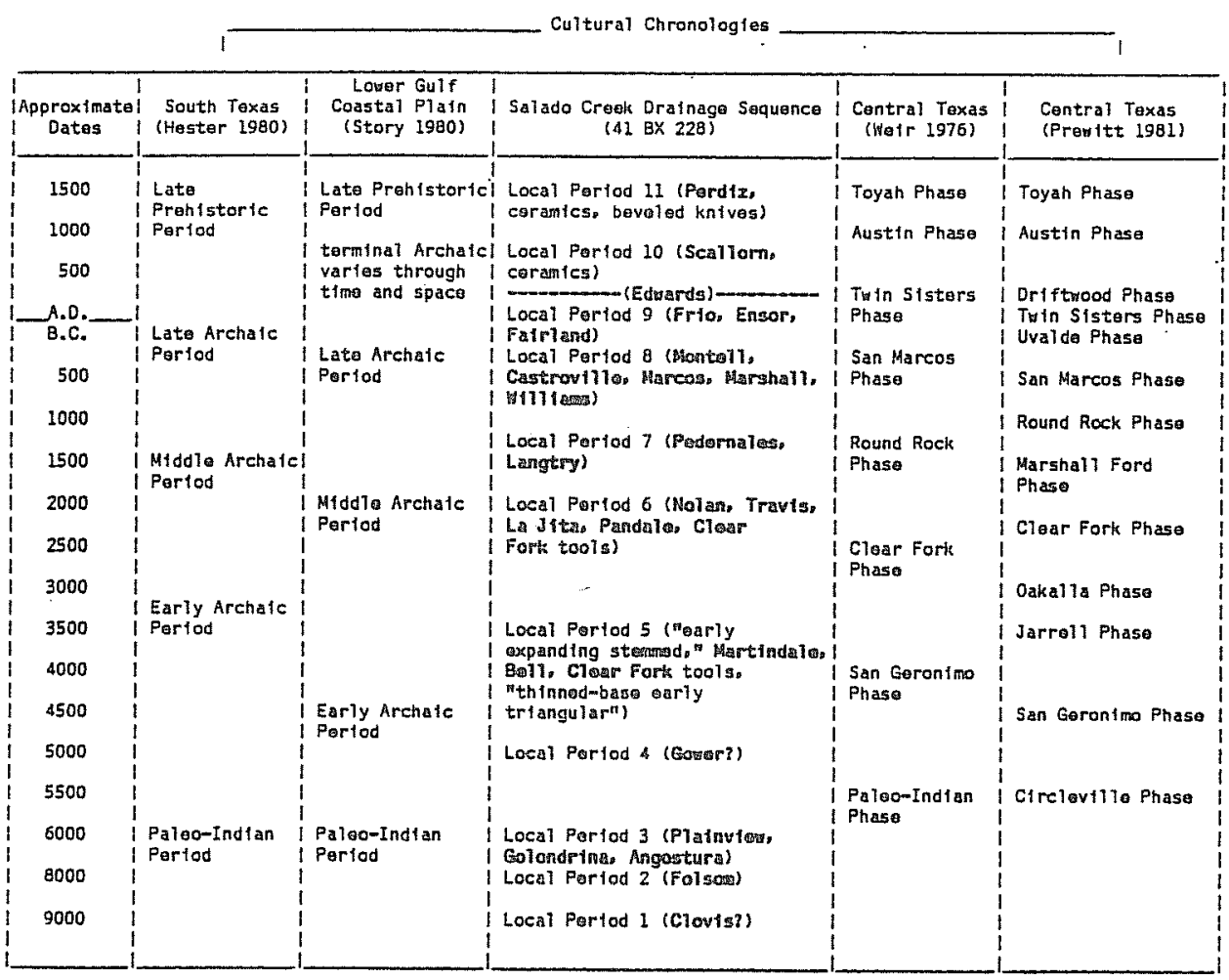

Pa] sosnvirongantal Dats

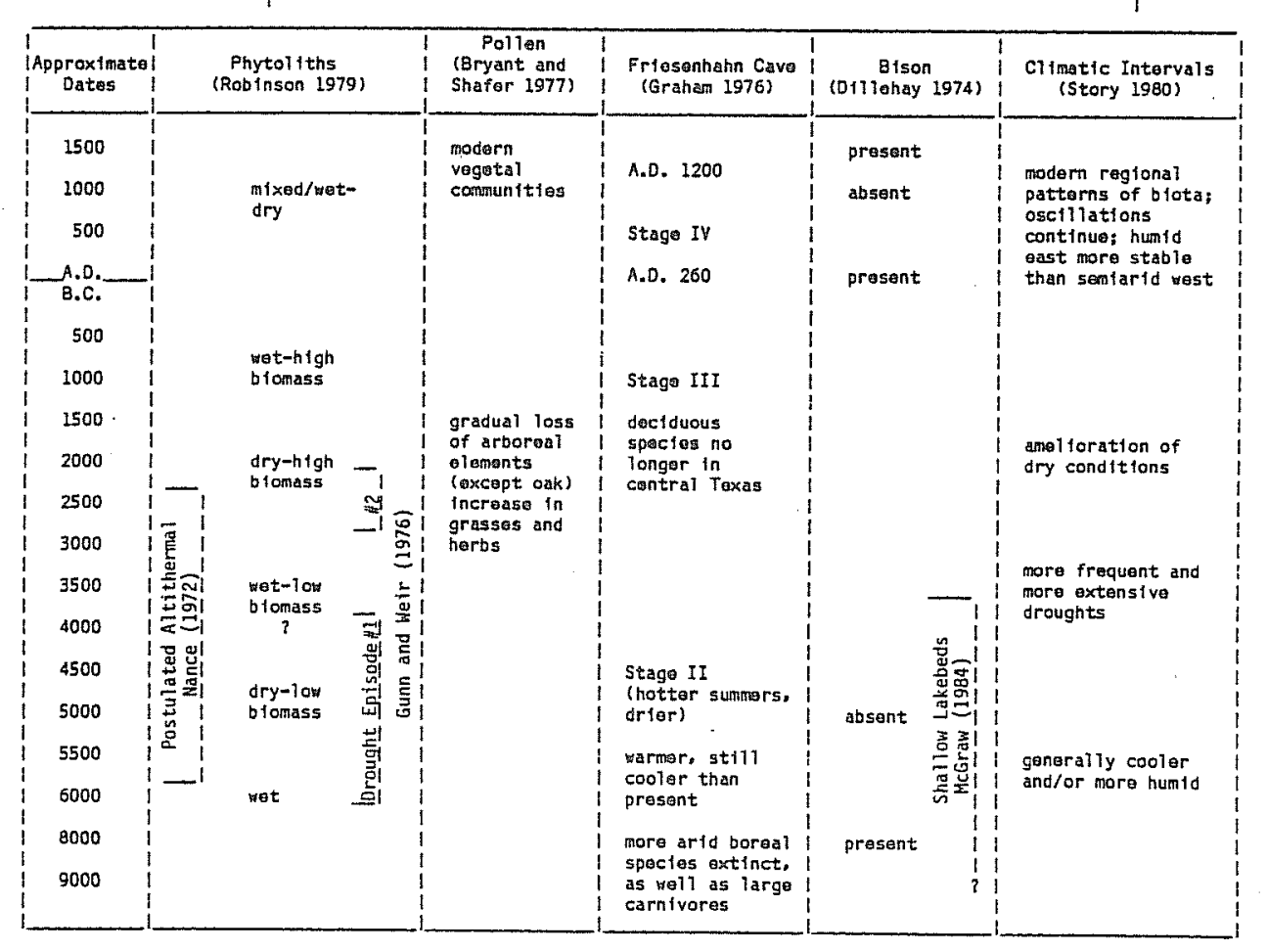


Paleo-Indian sites that are providing subsistence data have been reported along the margins of south and central Texas. These sites include the Horn Rockshelters (Watt 1978), Baker Cave (Hester 1979a), Hinds Cave (Shafer and Bryant 1977), and Berger Bluff (K. M. Brown, personal communication). Al 1 four have microfauna and/or smal1 game rather than extinct megafauna associated with Late Paleo-Indian deposits. This data supports the idea first suggested by Johnson $(1967: 82)$ that by 7000 B.C. a hunting and gathering life style ("Archaic") had been adopted across much of southwestern and central Texas and by extension south Texas. In 1 ight of this data and the absence of definite evidence of Early Paleo-Indian-megafauna associations across much of this area, the existence of a big game hunting tradition in the southern half of Texas is called into question. This question will on $7 y$ be answered by the careful excavation of one or more Paleo-Indian sites in the region with the rare combination of good preservation and clear-cut stratigraphy.

THE ARCHAIC PERIOD (ca. 6000 B.C. to A.D. 800)

The Archaic period in south, centra1, and the lower Pecos region of Texas can be regarded as a regional manifestation of a continental phenomenon (Jennings 1974:128-129). Some confusion may be caused by the uses of the term "Archaic" as applied to several cultural concepts as discussed by Shafer (1976b). Herein, the authors use the term "Archaic" to refer to the extremely long-lived hunting and gathering (foraging) tradition or series of adaptations to a post-Pleistocene environment in Texas. For practical purposes, the Archaic period is considered to begin with the widespread adoption of notched dart points following the Late Paleo-Indian era. Similarly, the end of the Archaic period is marked by the widespread adoption of expanding stem arrow points. The authors recognize that Archaic 1 ife styles (hunting and gathering adaptations) probably began during the PaleoIndian period and never really ended until the Historic period. Nonetheless, the Archaic period in south and central Texas is common $1 y$ understood to be the long time span in which stemmed and notched dart points were used.

It has long been recognized that during the 7000-year time span of the Archaic period in central Texas and adjacent regions, certain artifact types changed through time. Projectile point forms have been regarded as the most rel $i a b l e$ indicators of chronological change for several decades (Prewitt 1981). This remains true despite attempts to define chronological changes in other artifact forms (cf. Weir 1976a) and despite the addition of other cultural "dimensions" to the subperiods or phases of the Archaic (cf. Prewitt 1981).

The artifact types most common in south-central Texas and more specifically from $41 \mathrm{BX} 228$ are central Texas types. Additional1y, the Archajc chronological sequence of south Texas is poorly defined (Hester 1980), while the lower Pecos region Archaic sequence(s) often seem site specific (cf. Word 1970). For these reasons the following discussion of the chronological sequence of the Archaic will concentrate on central Texas. 
At the present time, a common ly accepted central Texas Archaic chronology does not exist. The most recently proposed sequences (Weir 1.976a; Prewitt 1981) have met with only partial acceptance. Weir's central Texas Archaic sequence, in essence, defined named phases that were equivalent to existing cultural constructs. For examp le, the San Geronimo phase encompasses the much disputed "pre-Archalc" (Soll 1berger and Hester 1972), while the Round Rock phase is equivalent to what was known as the Middle Archaic (Johnson, Suhm, and Tunnel 1 1962). Prewitt's (1981) recently proposed chronology involves several additional Archaic phases that represent the refinement or splitting of Weir's phases. The validity of Prewitt's scheme has yet to be demonstrated. In 7 ieu of an accepted regional chronology, a simplified tripartite division of the Archaic following Story (1980) will be used to discuss the Archaic period.

Story (1980) defines the Early Archaic as dating from approximately $6000 \mathrm{~B}_{0} \mathrm{C}_{.}$ to 3500 or $3000 B_{0} C_{0}$ the Middle Archaic from 3500-3000 B.C. to 1000 B.C.s and the Late Archaic as ranging from 1000 B.C. to approximately 200 B.C. or 1ater. She suggests that the distribution of Early Archaic sites in the West Gulf Coastal Plain and adjacent areas are geographically striking, and that ecotonal localities were emphasized. According to Story (ibido). Early Archaic sites generally are sma11, widely distributed, and nonspecialized. Story's (1980:15) explanation for this phenomenon postulates a culture(s) with high mobllity, frequent changes in group composition, poorly defined territories, and nonspeclalized extraction processes.

The increased frequency of Middle Archaic sites seems to reflect an expanding population distribution, the development of regionaliy distinct cultural patterns, and changes in settlement, technology, sacial systems, and territorial boundaries (Story 1980:15). In southern Texas. Hester (1978) proposed two general models of prehistoric exploitation: savannah and maritime adaptations, both possibiy of Late Archaic manifestation. Archaic sites in southern Texas may be (1) open campsites located near streams or tributaries: (2) lithic workshop sites (usually upland) centered around sources of siliceous cobbles: or (3) special activity sites (usualiy upland) such as temporary hunting camps or food-processing stations.

Weir (1976a:124-130) suggests that Middle Archaic interests in central Texas centered around nut-bearing hardwoods and deer. The accumulations of burned, fire- fractured 1 imestone rocks or middens. first identified in the Early Archaic and prominent in many of the later central Texas Archaic occupation sites, are broadly associated with food processing and may al so represent a specific exploitation of a required resource. Weir (1976a) suggests that Archaic sites in the central Texas area may be divided into four basic types: rockshelters, campsites (near streams), quarry sites, and kill sites.

During Late Archaic times, Story (1980) suggests that there was an intensification of previously existing cultural patterns. Ceramics were introduced in some portions of the state. The existence of 1 arge cemeteries during this time also seems to reflect the establishment of territories and subsistence schedules. Exploftation of natural resources apparently became increasingly divergent toward the end of the Late Archaic. 
THE LATE PREHISTORIC PERIOD (Ca. A.D. 800 to A.D. 1700)

The most recent cultural period in the prehistory of south-central Texas is herein referred to as the Late Prehistoric. Elsewhere the terms Neo-American (Suhm, Krieger, and Jelks 1954) and Neoarchaic (Prewitt 1981) have been used to denote the same period. The Late Prehistoric period includes all of the cultural manifestations in south-central Texas and surrounding areas after the introduction of the bow and arrow and before the acculturation. displacement, and disintegration of the indigenous cultures during the Spanish colonial occupation of the area. Hence, the term Late Prehistoric is used without reference to the use of the term in other regions of North America (Prewitt 1981:68).

In both south and central Texas the two most common arrow point morphological forms found in Late Prehistoric contexts are expanding stem and contracting stem forms. In central Texas Jelks (1962) has demonstrated that the expanding stem form (Scallorn) predates the contracting stem form (Perdiz). In south Texas this relationship has yet to be conclusively demonstrated. However, recent excavations at 41 MC 296 in the Choke Canyon Reservoir support a similar Late Prehistoric chronology in south Texas (G. D. Hall, personal communication).

In 1962, Jelks (1962) reported the results of excavations at the Kyle site, a stratified Late Prehistoric site in northern-central Texas. The Kyle site had two Late Prehistoric components. The oldest component contained mostly Scallorn arrow points, while the youngest contained mostly Perdiz arrow points. On this basis and, importantly, on the basis of associated artifact assemb 7 ages, Jelks ( 1 bid.) tentatively defined two foci of the Central Texas Aspect (Kel ley 1947b), the Austin focus and the Toyah focus. Surprisingly, these two Late Prehistoric subperiods are still accepted, although they are usually termed "phases" (Prewitt 1981).

The Austin phase begins prior to A.D. 1000 with the widespread adoption of the first true arrow point, the Scallorn point, in central Texas. Associated with the Austin phase are cemetery sites such as Loeve-Fox (Prewitt 1974). The succeeding Toyah phase begins around A.D. 1300. Toyah phase components are marked by Perdiz arrow points, beveled bifacial knives, small end scrapers, and bone-tempered ceramics. The Toyah phase coincides with the return of bison to the region (D 111 ehay 1974) and represents an adaptation emphasizing bison hunting. The Toyah phase has been tentatively 1 inked to the historic Tonkawa (Suhm 1959).

In south-central Texas and some areas of south Texas, concave-based expanding stem arrow points (Edwards) are more numerous than straight-based expanding stem arrow points (Scal1 0 rm). Mitchel1 (1978) has suggested that Edwards points mark the initial phase of the Late Prehistoric period, which he terms the Turtle Creek phase, in south-central Texas. This suggestion has not been supported by excavation results. The authors believe that Edwards and Scallorn points are contemporary variants on the same basic arrow point form. In addition, the authors believe that bone-tempered ceramics were introduced in south-central Texas before A.D. 1000, in other words shortly after the 
Late Prehistoric period began. These arguments will be further discussed in the following sections of this report.

THE HISTORIC INDIAN PERIOD (ca. A.D. 1525 to A.D. 1875)

The Historic Indian period is a relatively brief period that represents the final episode of indigenous Indian cultures in the region. Initial European contact occurred in the early l6th century; the most significant was Cabeza de Vaca's journey across southern Texas in 1528-1536 (Campbe 11 and Campbe 11 1981). The Late Prehistoric groups probably changed very 1 ittle until the close of the 17th century when the Spanish began establishing missions in south and central Texas (Hester 1980). Unfortunately, the Spanish missionaries and soldiers made little or no effort to record ethnographic data on local Indian groups. Two recent studies of certain south and south-central Texas Indian groups demonstrate the paucity of available ethnographic and ethnohistoric data (Campbe1 1 1975: Campbe11 and Campbel 1 1981). The combination of Spanish colonial contact with its missionization and foreign diseases and the simultaneous invasion of marauding Apache and 1 ater Comanche groups from the north virtually destroyed all elements of indigenous culture in south and central Texas by the early 19th century. Non-native Indian groups such as the Apache and the Comanche continued to be a 1 imiting factor in frontier 1 ife in Texas during the 19th century (Webb 1935; Newcomb 1961).

Archaeologically, the recognition of Historic period Indian sites in the region has been rare (Fox 1980). Sites dating to the 16th and 17 th century can be expected to contain occasional artifacts of European origin such as metal. glass, metal arrow points, glass arrow points, and trade beads. Easier to recognize are Indian artifacts commonly found at the Spanish missions. The lithic artifacts produced by the mission Indians bear oniy 1 imited resemblance to the Late Prehistoric 1 ithic assemblages (ibid.:272). By contrast, it has been suggested that the mission Indian ceramics such as the Gollad wares (Mounger 1959) represent a direct continuity with the bonetempered Late Prehistoric ceramics common in south and central Texas (Ha) 1, Black, and Graves 1982:452).

\section{ENVIRONAENTAL SETTING}

Site 41 BX 228 is located on Panther Springs Creek in north-central Bexar County. The site 1 ies within a stream valley bounded by rol 1 ing 1 imestone hills several kilometers southeast of the Balcones Escarpment. The Balcones Fault Zone forms the boundary between major physiographic regions and their associated biotic provinces: north and west of the Balcones Escarpment is the Edwards Plateau; to the east and southeast is the Black I and Prairie; and to the south and southwest is the south Texas Gulf Coast Plain. The location of the Panther Springs Creek site within the transition zone between these physiographic regions has important cultural implications. To understand the environmental setting of $41 \mathrm{BX} 228$, one must consider the following aspects: geology, physiography, biotic resources, hydrology, climate, paleoenvironment, topography, geomorphology, and soils. 


\section{GEOLOGY}

The Panther Springs Creek site 1 ies within the Balcones Fault Zone. During the Miocene Epoch, roughly 21 million years ago, faults began forming along the Balcones Fault Zone in south-central Texas, and eventually uplifted the Edwards Plateau with respect to the BI ack 1 and Prairie and the Gulf Coast Plain. The Balcones Fault Zone is comprised of a series of en echelon northeast trending faults. The width of the fault zone and the height of the escarpment vary considerably. For example, in northwest Bexar County near Helotes the escarpment is abrupt and the fau $1 \mathrm{t}$ zone comparatively narrow, while in north-central Bexar County near 41 BX 228 the escarpment is more gradual and the fault zone wider. In Bexar County, the Balcones Fault Zone has exposed and intermixed various upper and lower Cretaceous geologic formations of 1 imestone, chalk, marl, shale, siltstone, and dolomite, resulting in considerable localized diversity.

Within a kilometer of 41 BX 228, three geologic formations are exposed on the surface: the Austin Chalk, the Buda Limestone, and the Eagle Ford Group. Upstream from the site are two other important geologic formations, the Edwards Limestone and the Glen Rose. Each of these formations has contributed 1 ithic resources and weathered soil constituents to the immediate site area and are thus, archaeologically significant. A brief description of each formation follows; this information was derived from the San Antonio sheet of the Geologic Atlas of Texas published by the Bureau of Economic Geology (Barnes 1974).

\section{UPPER CRETACEOUS FORIATIONS}

\section{Austin Chalk}

The Austin Chalk formation outcrops west of site 41 BX 228 and is composed of chalk and marl. The chalk is mostly microgranular calcite and averages $85 \%$ calcium carbonate. Pyrite nodules are common and, in part, weathered to limonite. The Austin Chalk is highly fossiliferous in some localities.

\section{Eagle Fard Group}

The Eagle Ford Group outcrops east of site 41 BX 228 on the hilltops. It is composed of shale, siltstone, and 1 imestone which tend to be broken into thin tabular pieces suitable for flagstones.

\section{LOWER CRETACEOUS FORMATIONS}

\section{Buda Limestone}

The Buda Limestone outcrops east of site $41 \mathrm{BX} 228$ below the Eagle Ford Group. Buda Limestone is fine grained, hard, and poorly bedded to nodular. It is pale orange and weathers to dark gray or brown. This formation also contains pyrite and fossil pelecypods. 


\section{Edwards Limestone}

The Edwards Limestone is the most important geologic formation in the area both prehistorically and currently. Outcropping several kilometers upstream from the site, it is composed of fine- to coarse-grained 1 imestone with abundant chert and foss11s; solution zones and collapse breccia (highly fragmented rock) are al so common. Most of the residents in south-central Texas depend upon the Edwards Aquifer for municipal and irrigation water. In the past, the abundant chert derived from the Edwards Limestone was the major 1 ithic resource for chipped stone tools in the region. Most of the gravels underlying $41 \mathrm{BX} 228$ and littering the stream bed adjacent to $41 \mathrm{BX} 228$ were derived from the Edwards Limestone.

\section{Glen Rose Formation}

The Glen Rose outcrops upstream from the Edwards Limestone and is composed of alternating 1 ayers of 1 imestone, dolomite, and marl. The differential weathering of these constituents results in the characteristic "stair step" topography of the southern Edwards Plateau. The headwaters of Panther Springs Creek are approximately $20 \mathrm{~km}$ north of the site and within the Gien Rose Formation.

\section{PHYSTOGRAPHY}

Three major physlographic regions can be found within Bexar County: the Edwards Plateau, the Blackland Prairle, and the Gulf Coast Plain. The Edwards Plateau lies several kilometers north of the Panther Springs Creek site in a vast uplifted plateau commonly referred to as the "Hill Country." The 1 imestone tablelands, which originally formed the plateau, have been highly dissected and incised by deep and often very narrow stream courses. The resulting high relief topography is scenically rugged. Soils are characteristically thin and rocky on the Edwards Plateau except for the deeper alluvial bottomlands along the narrow stream valleys.

To the east and southeast of the Edwards P 1 ateau is the B 1 ack 1 and Prairie, with its gently rolling topography and comparatively lower relief. Stream courses are broad alluvial valleys. Solls on the Blackland Prairie are usually very deep and composed chiefly of clay and silt.

In southern Bexar County, sandy soils mark the South Texas Coastal Plain, a subdivision of the Gulf Coast Plain. The South Texas Coastal Plain has gentle rolling hills in the Bexar County area giving way to flat terrain as one approaches the coast.

The Balcones Fault Zone, in which 41 BX 228 is located, forms a transition zone between these physiographic regions. In the general area of the site, the transition is primarily from the Edwards P I ateau to the B 1 ack 1 and Prairie. The hills surrounding the Panther Springs Creek valley are not as large or as high as those on the Edwards Plateau, and the stream gradient and broadness of the stream valley are intermediate between the two physiographic 
regions. Soils within the stream valley are deeper and somewhat less rocky than those of the Edwards Plateau.

\section{BIOTIC PROUINKES}

Three major biotic provinces are associated with the three physiographic regions which converge in Bexar County: the Balconian Biotic Province associated with the Edwards P Tateau, the Texan Biotic Province associated with the Blackland Prairie, and the Tamaulipan Biotic Province associated with the South Texas Coastal P Iain (B1 air 1950). Fauna and flora present today and prehistorically within the immediate site environs reflect the location of the site within a transition zone between the Balconian and Texan Biotic Provinces and its lesser proximity to the Tamaul ipan Biotic Province.

The Balconian Biotic Province is characterized by a variety of faunal species

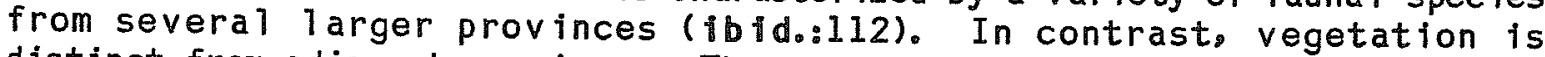
distinct from adjacent provinces. The most characteristic upland association is the scrub forest of Mexican cedar. Texas oak, and stunted 1 ive oak prevalent in the upland regions. Riparian environments associated with the often narrow floodplains along streams on the Edwards Plateau are dominated by mesic forests of 1 arge 1 ive oaks, elms, hackberries, and pecan. Recent statistical studies (Van Auken, Ford, and Stein 1979) on the southern Edwards Plateau have quantitatively demonstrated that species diversity and density of woody vegetation are much higher in riparian than upland environments.

The Texan Biotic Province contains both the oak-hickory timberlands characteristic of sandy soils and the tall-grass prairies associated with clay soils such as the Black land Prairie. Dr. Ferdinand Roemer $(1849: 118)$, traveling from New Braunfels to San Antonio in 1846, recorded an open prairie between the Cibolo and Salado Creeks. He specifically noted the forested $v a 1$ ley of the Sal ado Creek and a "thick mesquite brushwood, ten to twel ve feet higher" (ibid.:119) between Salado Creek and the San Antonio River. F. 01 msted (1857), while traveling through Texas in the 1850s, al so commented on the open prairies that extended almost level to the coast south and west of San Antonio, while the "mountain country" was located five or six miles to the north. $01 \mathrm{msted}$ (ibid.:151) contrasted this flora to the $1 \mathrm{imitiess,}$ almost impenetrable, chapparal on the outskirts of the town: ". . . by a wa 11 of these mesquit (sic) thorns the road is soon closed in. Almost a 11 the roads of entrance are thus 1 ined, and so the city bristles 1 ike a porcupine, with a natural defense." Gould (1969) states that the Black 1 and Prairie was a true prairie in the recent prehistoric period, with 1 ittle bluestem as the dominant grass type; the tal1-grass prairies are now 1 argely under cultivation.

The Tamaulipan Biotic Province is today dominated by thorny brush, but early historic records indicate grassland and savannah communities for much of the south Texas plain. In fact, the historic invasion of brush species into a 71 three provinces has been we 11 documented (Bray 1906; Bogush 1952; Ing 1 is 1964; Gould 1969). Intrusive species such as mesquite, whitebrush, and juniper have dramatically increased their ranges and densities. The principal reasons for this invasion are: (1) the introduction of cattle by the 
Spanish in 1690 and subsequent overgrazing in the 19th century: (2) cultivation of soil resulting in increased erosion and depletion of minerals; (3) absence or control of prairie fires: (4) fencing of grass 1 ands; and (5) extermination of the buffalo herds. The proliferation of brush species has been most dramatic since the mid-1800s. Ganah1 Walker, Jr. (personal communication. 1980) states that mesquite and whitebrush did not choke the Walker Ranch prior to 1930. Photographs of the ranch taken in 1924 clearly support his statements.

In small ecological niches of south-central Texas, where modernization and agricultural impacts have been minimal, remnant biological communities still exist. One such locality is the Lost Maples Natural Area in Bandera County (ca. 60 miles west and 51 ightly north of $41 \mathrm{BX} 228$ ). The area is characterized by the uncommon occurrence of Bigtooth Maples (usually found in more moist areas of North America). Nearby, in portions of Real County, Alderson. Alderson, and Turner (1972) have discovered ancient relic stands of pinyon pine which. while native to the area, are today usually found in western Texas. They also noted an unusually high diversity of avifauna in the same area, including birds common to the Rio Grande Valley and Mexico, shore and water birds, rare Mexican songbirds, and western Texas arid country birds. Elsewhere, in describing the past flora of the Edwards Plateau. Warnock (1970) states that the area once supported thousands of acres of sotol. the majority of which was cut for cattle during the great drought between 1880 and 1910 .

\section{HYDROAGGY}

Site 41 BX 228 is situated on a raised terrace or bluff on the east bank of Panther Springs Creek approximately $1.4 \mathrm{~km}$ upstream from its confluence with Salado Creek. Panther Springs Creek was apparently given its name by an engineer or cartographer in recent decades: 1ifetime residents of the area such as Ganahl Walker, Jrag have always referred to Panther Springs Creek as the Salado Creek. The stream now referred to as Salado Creek 1 ies west of the site and was formerly called the Dry Salado Creek to distinguish it from Panther Springs Creek. Both streams originate in the extreme southern edge of the Edwards Plateau $17-25 \mathrm{~km}$ upstream from their confluence. The Salado and Panther Springs Creeks form a major drainage system for much of northern and central Bexar County. Salado Creek is a tributary of the San Antonio River, which is part of the Guadalupe River drainage system.

Today Panther Springs Creek is dry except for a few waterholes or for brief perlods after heavy rain. Prior to 1930, however, Panther Springs Creek was a flowing stream fed by springs approximately $1 \mathrm{~km}$ upstream from $41 \mathrm{BX} 228$. These springs were strong and reliable enough to keep the creek flowing in al1 but the driest years (Ganahl Walker, Jrog personal communication). Just below the springs is Higgins Waterhole, named for one of the early owners of the property (Cox and Fox ms.). Although no longer spring fed, Higgins Waterhole continues to hold water: since 1899, it has gone dry only once at the end of the 1950-1957 drought (Ganahl Walker. Jro, personal communication). Nineteenth century references, such as Bonnel 1 (1840:95-96), who described the Salado Creek as a "small but beautiful stream which rises from 
a spring about twelve miles north of the city of San Antonio," and Roemer (1849:118), who referred to Salado Creek as a "clear brook," support the interpretation that Panther Springs Creek was formerly a reliable stream.

Higgins Waterhole is the largest of a number of waterholes which lie along Panther Springs Creek. These waterholes were formed through at least three different processes. Higgins Waterhole, like many of the larger waterholes, was formed where a bed of resistant material (harder 1 imestone) crosses the stream bed perpendicular to stream f10w. Softer formations upstream have weathered away leaving a depression and a bedrock dam. Smaller waterholes were formed either by scour holes or by coll apsed sinkholes and solution cavities. Scour holes form near bends in the creek or below outcrops or major tree roots when floodwaters "scour" or clean out a small depression. such as the one at the southern end of the site. Collapsed sinkholes or solution cavities are less common. An excellent example occurs adjacent to the site. This formed when an underground solution cavity coll apsed, perhaps due to the lowering of the water table (Glen Evans, personal communication). The resulting depression has a faulted bedrock floor (Fig. 2,a). Prior to 1930, al1 three waterhole types would have held water all or most of the year.

The Edwards Aquifer, as previously mentioned, has been an important water resource in the area. The faulted or cracked formations and solution cavities of the Balcones Fault Zone allow surface water to recharge the aquifer. Artesian water circulating through the aquifer is blocked in its southward movement by the major faults of the zone. The underground water general1y changes course to flow easterly and northeasterly toward the major fault 1 ines in nearby San Antonio. New Braunfels, and San Marcos. The discharge from the largest of these artesian springs, Comal Springs in New Braunfe 1s, averages approximately 303 cubic feet of water per second (ca. 2266 gallons/second; Pass, ed. 1979:105). The southern 1imit of the artesian aquifer is relatively we11 defined as the "bad water 1 ine." South of this boundary, the water is charged with noticeable amounts of hydrogen sulfide, and there is an appreciable increase in the hardness of the water (Austin et a 1. 1975:60).

The existence of the Edwards Aquifer and its water resources are thought to have been one of the most significant natural influences on 1 ocal and regional prehistoric activities. Subsistence and occupational patterns revolved around the availability and location of the aquifer-associated artesian springs. The fluctuation of water levels from the prehistoric aquifer through time are thought to be directly related to the distribution of archaeological sites. As an example, Arnow (1959:28) states that modern studies of the Edwards Aquifer show that areas of the greatest decline in water levels are not the areas of greatest discharge for the aquifer. The largest discharges occur in or near the city of San Antonio and in an area to the southwest and the northeast. This area of small decline and 1 arge discharge coincides with the area of greatest faulting, which apparentiy has developed an extensive system of solution cavities. These cavities act as a natural subsurface transport system which both stores and moves water throughout the system. The water movement is so great in these areas that it results in an unequal effect of discharge rates throughout the aquifer. It 
is suggested that in prehistoric times, as varying factors may have affected the level of the aquifer, specific areas of the aquifer zone would have had substantially more reliable water resources, even considering the effects of long-term droughts or dry conditions. The reliability of these artesian water sources would be reflected archaeologically by the increased activity and extensive occupations within or near these resources. The authors suggest that the springs north of the present-day Higgins Waterhole was one such area and that $41 \mathrm{BX} 228$ is an integral part of this ecologicalarchaeological relationship.

\section{CLIMATE}

South-central Texas has a modified humid subtropical climate: mild winters (continental influence) and hot humid summers (maritime influence). Precipitation averages about 28 inches per year but varies greatiy on a year-toyear basis. Friedman (1957) provides bar graphs illustrating yearly climatic variation in Texas from 1915 to 1955 at various weather stations. The San Antonio bar graph has a near normal bel 1 curve from arid to humide peaking at dry subhumid, indicating that San Antonio experiences a wide range of climatic variability. Precipitation is "normally" spread throughout the year, with high rainfal1 peaks in May and September and 10 w rainfal 1 periods in summer and winter. The growing season is quite long, averaging 268 frostfree days. Snow is rare, as are temperatures below $20^{\circ} \mathrm{F}$. Prevailing winds are southeasterly from the Gulf except during the winter, when northers (arctic air masses with winds from the north and northwest) frequently bring several days of subfreezing temperatures. Rainfall extremes (i.e.s droughts and floods) are the major limiting climatic factors.

In south-central Texas, short-term droughts (several months) are common, and long-term droughts (over one year) occur at irregular intervals. Friedman (ibid.:162) tried unsuccessfully to predict long-term drought and concluded that "it is very unlikely that the climate of south and southwest Texas is subject to regularly recurring cycles of wet and dry spel1 1s." More recently, Gunn (1979) has attempted to predict drought periods using new techniques and information. He was able to identify some of the factors responsible for climatic variablitity ( $\theta_{0} g_{0}$ sunspot activity) but has not yet succeeded in predicting long-term conditions.

Central Texas is also one of the most flood prone areas of the United States. Cloud bursts, usually occurring between May and September, have resulted in national and worldwide records of rainfal1 within a given time (Baker 1975). These thunderstorms are often triggered by warm moist Gulf Coast air rising and encountering cooler air over the Edwards Plateau. The heavy rainfal 1 in short time spans coupled with the thin rocky solls, steep slopes, and narrow canyons of the area result in spectacular floods. Baker (fbid.) illustrates several examples of how localized flooding can change topography and vegetation overnight. 


\section{PALEOENUIRONMENT}

Recent changes in the environment surrounding 41 BX 228 are comparatively well understood. The farther back in time one goes, the more difficult it becomes to accurately assess the changes in environment. The most radical local environmental changes within the past 10,000 years probably occurred recently as the result of historic 1 and use practices and increasing urbanization. Within the 1 ast 100 to 150 years the grasslands and riparian zones have been choked with thorny brush. and the springs upstream from the site no longer flow. In order to consider how the paleoenvironment would have differed from the modern environment, an inferred model of the site setting as it would have appeared during the Late Prehistoric (ca. A.D. 1400) is described. This model is based on the archaeological record, historic accounts, and environmental data from adjacent areas. 0ther models are discussed for the site setting prior to A.D. 1400. Additional comments on regional paleoenvironmental data are discussed in section $X I$.

\section{SITE SETTING (ca. A.D. 1400)}

Near the onset of historic occupation in the area, Panther Springs Creek was a shallow stream flowing year round. A clear pool of water in the collapsed sinkhole adjacent to $41 \mathrm{BX} 228$ provided a reliable water source for the peoples who visited the site. They camped within a narrow band of trees on the bluff overlooking the stream. This riparian zone would have had diverse flora dominated by larger tree species (e.g०o live oak, Texas oak, hackberry, and $e 1 \mathrm{~m}$ ). Also present were wal nut (two species), persimmon, acacia (several species), mesquite (much less numerous than today), and three species no longer common in the area-ash, willow, and pecan. The 1 imestone hills which bounded the creek valley on either side were covered with cedar (juniper) and various stunted hardwoods, much as they are today. Between the wooded creek bottom and the cedar-covered hills, the terrain became flatter, and the valley broadened south of the site. This area, which today is choked with thorny brush, would have been a prairie grassland dominated by 1 ittle bluestem and other grass species and punctuated by mottes of 1 ive oak and isolated areas of brush.

The prairie grasslands would have provided an excel lent habitat for pronghorn and bison. Most of the other animal species present around the site are those found in the area today. Exceptions include gray wolf, bison, and pronghorn, which are now locally extinct. A perennial stream would have supported turtles, fish, and some terrestrial species (e.g., raccoons) which rely heavily on aquatic resources. Low recovery of mussel shel 1 and fish bone at 41 BX 228 suggests that Panther Springs Creek remained shal low in the vicinity of the site. A well-watered riparian zone adjacent to the grasslands would have supported a very diverse faunal assemblage with much higher populations than are present today. 
SITE SETTIRG (Ca. A.D. 1400 to 8000 B.C.)

Two contrasting models of climatic change from $A_{0} D_{0} .1400$ to 8000 B.C. have recently been suggested for the general south-central Texas area. Bryant and Shafer (1977) have presented a model of late Quaternary vegetation patterns in Texas that suggests a gradual warming and drying trend during the postglacial period ( 8000 B.C. to present), with a possible short-lived mesic interval occurring at about $500 \mathrm{~B}_{0} \mathrm{C}_{\mathrm{s}}$ in several areas of Texas. However, the final 2000 years of Bryant and Shafer's (ibid.) model is poorly defined due to inadequate pollen preservation.

In contrast to the gradual trends proposed by Bryant and Shafer (1977), Story (1980) describes a steplike mode1. In her synthesis of environmental data of the West Gulf Coastal Plain, three provisional climatic intervals are discussed. Between 7000 and 5000 B.C., Story $(1980: 6)$ bel ieves that "the climate was generally cooler, and/or more humid." Vegetation communities were not as fully differentlated into the communities present in recent times as in the model presented above. Between 5000 and 3000-2500 B.C., droughts were more frequent and more widespread. Story (1bido:7) suggests that two drought episodes such as those proposed by Gunn and Mahula (1977) are more 1 ikely than a single extenuated droughto Plants able to subsist at lower moisture levels expanded their ranges during this period, and bison were probably rare if present at all in the area. Between 3000-2500 and 1000 B.C.s drier conditions were broken by apparent fluctuations in climate, i.e., wetter periods when tal1 grasses and bison were more numerous. By $1500 B_{0} C_{0}$. Story $(1980: 8)$ bel leves that "essentially modern regional patterns of biota were established." Story $\left(1 \mathrm{~b} / \mathrm{d}_{0}\right)$ concludes that significant climatic fluctuations probably occurred throughout the 1 ast 10,000 years. although these changes should be considered as influencing rather than determining adaptation factors. Both Story (1980) and Bryant and Shafer (1977) point out the insufficient and often inconsistent nature of the environmental data on which they base their models.

Story's (1980) model of climatic fluctuations during the 7 ast 10,000 years seems to be the most viable model applicable to 41 BX 228. Periods of prolonged drought occurring between 5000 and 2500 B.C. could have resulted in the shortuterm drying up of Panther Springs Creek. Bison and possibly pronghorn would not have been present during this time. By $1500 B_{0} C_{.}$, the plant communities described for the A.D. 1400 model were probably we 11 established. In addition. bison may have ranged farther south during wetter periods and would have been present near the site. The site faunal assemblage clearly reflects a much greater emphas is on bison during the 1 ast 3000 years as opposed to the 5000-1000 B.C. period. Dillehay's (1974) periods of bison presence appear to correlate with the inferred mesic intervals and archaeological record quite well.

In conclusion, throughout much of man's accupation at $41 \mathrm{BX} 228$, the local environmental setting was not radically different from the model presented for $A_{0} D_{0}$ 1400. Perlods of increased aridity may have limited occupation at $41 \mathrm{BX} 228$ and influenced local adaptive strategies, but the ecotona 7 location of the site and the probable avallability of water during most of the site's 
occupation offered a generally favorable environment with diverse biotic resources.

\section{TOPOGRAPHIC SETIING}

The Panther Springs Creek valley is sharply delimited by 1 imestone hills just north of 41 BX 228. The valley in this area is less than a kilometer wide and becomes narrower and more sinuous to the north. Adjacent to the site, the valley broadens into a wide, poorly defined floodplain which merges with the Salado Creek floodplain and forms one of the largest relatively flat areas in north-central Bexar County. The site is located on the outside or eastern bank of a smal1 bend in Panther Springs Creek.

Site 41 BX 228 is concentrated along the edge of a raised terrace or bluff. The bluff edge is $2.5-3.5 \mathrm{~m}$ above the creek bed in the vicinity of the site. The bluff tapers at the north end of the site where a small tributary drainage enters Panther Springs Creek. Immediately upstream and north of the site, Panther Springs Creek has two distinct channels connected by several smaller crisscrossing channels, resembling a braided stream. Terrace remnants composed primarily of gravels remain as "islands" between some sections of the braided stream. These features have 1 ittle soil development, but sustain considerable vegetation. Farther south, the two channels merge adjacent to the site and form a single we11-defined channe1. An atypical terrace remnant is located adjacent to the north end of the site. This feature, known informally as "Herb's Knoll" (Fig. 2,b), was formed by alternating gravel and silt layers.

Figure 1, a topographic map of $41 \mathrm{BX} 228$, shows the relationship of the excavation units to the immediate site area. The most concentrated areas of cultural material were on the flatter portions of the site. When the site was first recorded, the area that centered on BT 5 appeared as a sma 11 but distinct rise or mound. Earlier testing and heavy pothunting in this area obscured this mound by 1979, but a more noticeable rise was discovered while clearing the north end of the site. This rise, centered between Area $A$ and BT 10B, had the highest elevations within the site.

\section{GEOMORPHOLOGY AND SOTLS}

The cultural materials at 41 BX 228 occur primarily in soils built upon late Pleistocene terrace deposits. 1 Since no radiocarbon dates were obtained from the terrace deposits, the late Pleistocene assignment is based upon broad, regional patterns of geomorphological development. The 1 ate Pleistocene terrace deposits underlie all site areas with the partial exception of the rise in the northeastern area of the site (Area A vicinity), where cultural materials were deposited on an outcrop of 1 imestone bedrock. The Pleistocene

IGlen L. Evans served as geomorphological consultant. Many of the interpretations in this section are derived from discussions with Evans. 
terrace consists mostly of gravel deposits ranging in thickness from as little as $10 \mathrm{~cm}$ to over one meter. The underlying terrace deposits consist of cobbles, sand, silt, and clay, but gravels are by far the dominant terrace constituent. Many of the terrace deposits can be attributed to broad sheet deposits left during the 1 atter part of the Pleistocene (9000 B. C.), when Panther Springs Creek was a much wider streams $3-5 \mathrm{~m}$ above the current stream bed. Adjacent to the bluff, in the vicinity of BT 2, the terrace deposits are more complex. Underlying the sheet deposits are crossbedded remnants of several different terrace fills, including smali gravels in a sandy matrix as well as large cobbles with a sandy matrix. Figure 4 (BT 2) illustrates the deepest profile at the site. The profile probably contained an even more complex terrace fill sequence than was recorded.

The terrace deposits resulted from a variety of stream flow conditions. The 1 arge cobbles were left by very high-energy floods. Although most of the deposits are poorly sorted, we 17-rounded, pebble-sized gravels predominate. This suggests that the gravels were transported long distances (relatively speaking) and represent secondary and tertiary reworking of previous Pleistocene terraces (Glen Evans, personal communication). The gravels frequently contain considerable quantities of silt and sand; the "dirty" appearance suggests a turbulent depositional environment. In other words, they probably result from short-term flooding rather than long-term washing and sorting typical of larger more permanent streams.

The gravel deposits reach maximum thickness at the southern end of the site in the vicinity of Areas $H$ and $I$, approximate 1 y $6-10 \mathrm{~m}$ away from bluff's edge. The upper surface of the gravel terrace deposits exhibits considerable postdepositional erosion in this area. At the eastern end of BT 2 (Fig. 4), a filled stream channel is visible in the profile. This stream channel appears to have formed after the gravel terrace had been deposited. This feature probably represents a secondary channel of Panther Springs Creek which was short-lived and soon filled with fine-grained clay and silt. This abandoned stream channel and similar features in other parts of the site have a characteristic deep rusty red color resulting from the oxidization of the iron-rich soil. Smaller channel fills are also visible in the gently undulating sheet deposits. These smaller channels are several meters wide and $50 \mathrm{~cm}$ in depth. They apparently represent small erosional runoff channels which cut through the gravel beds and were subsequentiy filled with soils and gravel that are noticeably darker than the surrounding gravels. Flakes, tool fragments, and bone from these deposits (Area H) suggest that the site was occupied while the terrace was being eroded. With the exception of the small channels, most gravel deposits contain only occasional occupational material in the upper $5-10 \mathrm{~cm}_{\mathrm{s}}$ No cultural zones were observed below the upper gravel deposits.

Subsequent to the formation of the gravel terrace deposits, Panther Springs Creek began downcutting, becoming entrenched within its present boundaries early in the occupational history of the site (Glen Evans, personal communication). After the filling-in of the smaller stream channels, no evidence of any major erosional flood episode was observed within occupational levels of the site. Overbank flooding contributed some clay and 
fine silt to the site deposits and caused minor erosion along the bluff but did not significantly alter the site's cultural deposits.

The vast majority of the cultural materials recovered from $41 \mathrm{BX} 228$ were found above the Pleistocene gravels within comparatively recent soil deposits. It is important to note that these recent deposits are poorly developed, immature soils composed of a variety of constituents rather than mature soils developed in situ over parent material. The term soil is used loosely to include all the unconsolidated matrix or "dirt" occurring above the gravel deposits (see Birkeland 1974 for contrasting definitions of soil). Fiscal 1 imitations precluded any of the analyses common $7 y$ used to technically describe soil types and to exp 1 a in modes of formation (see Shack 1 ey 1975). The following information was derived from field observations and should be considered as provisional interpretations lacking analytical confirmation.

The extensive backhoe trenching and excavation units at $41 \mathrm{BX} 228$ provided soil profiles from most areas of the site. Across the site, significant differences in composition, thickness, and modes of formation were revealed in soil profiles. Many of these differences can be attributed to intensive human occupation over thousands of years. This repeated pattern of human occupation has resulted in the development of archaeological sediments (ibid.) rather than natural or undisturbed soils such as those surrounding the site. Three natural soil series have been formaliy defined for the general area by the Soil Conservation Service (Taylor. Hailey, and Richmond 1966): Patrick soils, Lewisville soils, and Trinity/frio soils. The descriptions of these natural soils, however, offer 1 ittle information of specific value in interpreting the site deposits. To understand the site deposits at $41 \mathrm{BX} 228$, one must first consider the implications of archaeological sediment development.

Even recent soils at $41 \mathrm{BX} 228$ must be considered archaeological sediments because of the extent to which human occupation has influenced their formation. The archaeological sediments at the Panther Springs Creek site were created by various human disturbances of the natural processes of soil formation. These include modifications of the existing surface ( $e_{0} g_{0}$, prehistoric excavations or pits), additions of cultural material, and less obvious changes such as in soil chemistry.

The extent to which each of these factors has affected site deposits cannot always be clearly determined. Surface modifications at specific occupation intervals might have included removal of surface rock to clear areas of the site, compaction of trails or 1 iving floors, removal of vegetative cover (thus reducing leaf 1 itter), and construction of temporary shelters; yet evidence of these and similar activities has often been subsequently obliterated. Other prehistoric modifications indicated by pit out ines were observed in several profiles. Shallow pits, probably more common during the various occupation periods, were difficult to recognize, due to the homogeneous nature of many of the site sediments. On the other hand, the addition of cultural materials was a more obvious and easily identifiable element of the archaeological sediments at 41 BX 228. Literal1y tons of burned rock (heat-fractured 1 imestone) had been added to the site deposits as sma 11 aggregates (burned rock clusters), as 1 arge aggregates (burned rock 
middens), and as scattered rock found in virtual 1 y a 11 areas of the site. Chert debris resulting from knapping also occurs throughout the site deposits. Other nonperishable cultural materials occur in smaller quantities. Perishable materials originally added to the site deposits would have included many items that are no longer preserved (e.g.s leather, basketry, and plant processing residue), as well as items which are on 1 y partially preserved (e.g.s bone and charred plant remains). Human occupation has also altered subtle soll characteristics. The reader is referred to section VII for a discussion of soll chemistry.

The recent soils at 41 BX 228, composed largely of archaeological sediments, range from $30 \mathrm{~cm}$ to over one meter in thickness. Soil depth (surface to bedrock or gravel horizon) is noticeably deeper in areas of intense prehistoric occupation than in the marginal fringes of the site or in offsite areas. In general, the solls at $41 \mathrm{BX} 228$ are highly calcareous and consistently alkaline (average pH 7.92). Most interfaces between soil 1 ayers or horizons are gradual rather than abrupt; thus, the exact boundaries between horizons are seldom as distinct as the illustrated profiles may suggest. The major soil layers or horizons are described below. Each is a distinctive layer recognized at several site locations.

\section{UNCONSOLIDATED ORGANIC MATERIMLS ("TOPSO $7^{\prime \prime) ~}$}

Virtually al 1 areas of the site are capped by a distinctively dark 1 oose soil layer commonly referred to as the "topsoil." The topsoll is an organically rich layer (organic carbon content ranges from 4\% to $8 \%$ ) which is made up of humus or decomposed organic materials, as well as intact organic materials such as leaf 1 itter, acorns, and roots. Munse 11 readings (taken dry) ranged from 10 YR 3-2/1-2 (b) ack to very dark grayish brown). The topsoil ranges in thickness from 5 to $35 \mathrm{~cm}$. The upper portion of the layer is $100 \mathrm{se}$ and easily disturbed, while the lower portion of the layer, particularly where the layer is thick, is more compact or stable. Across the site, several trends in topsoil variation were observed. The topsoil becomes thinner and more clayey south of BT 4. possibly due to both the decreasing intensity of occupation as well as the decreasing density of vegetative cover. As the northern end of the site (Area A vicinity) was cleared, a $5-10 \mathrm{~cm}$ iayer of leaf 1 itter (intact leaf to partially decomposed leaf fragments) was removed from the topsoil. The leaf litter was very thin at the south end of the site except under oak trees.

Cultural materials attributable to Late Prehistoric occupations were common in the topsoil. particularly in the lower portions of the 1 ayer. Earlier materlals do occur, but these represent displaced artifacts from lower deposits. Intact cultural features such as Feature 1 occur within the topsoi1. The topsoil probabiy represents the last major occupation of the site during the Late Prehistoric, as wel1 as the accumulated natural soil buildup during the 1 ast $600-800$ years since the site was abandoned. Thus, the topsoil is partially an archaeological sediment and partially a natural soil layer. The distinctive dark color can be attributed primarily to a high organic content. 


\section{"B-HORIZON" AMD MIDDEN MATRIX}

In all areas of the site, the soil beneath the topsoll was 1 ighter in color and finer in texture and exhibited a marked decrease in organic content. The term "B-horizon" became entrenched in the project 1 iterature (field notes, profiles, etc.) with regard to this soll layer, although it was not equivalent to a B-horizon as commonly defined in soll 1 iterature (Birkeland 1974). The B-horizon is a silty loam that varies in thickness, color, and structure across the site. In general, this layer is gray brown and ranges from $15-20 \mathrm{~cm}$ in thickness. The B-horizon is more compact than the topsoil but noticeably more friable than the underlying 7 ayers. Dry Munse 11 values ranged from 10 YR $3 / 2$ to 10 YR $4 / 2$ and 10 YR $3 / 3$ (very dark grayish brown to dark brown and dark grayish brown). The same trends of increasing clay content and decreasing thickness from north to south that were evident in the topsoil were also observed in the B-horizon.

Al1 of the burned rock middens at 41 BX 228 were located within the Bhorizon. While the midden matrices often appeared 1 ighter in color and less compact than the surrounding B-horizon soils, they were not separated for il lustrative purposes. Munsel 1 values of midden matrices ranged from 10 YR $3 / 2$ to 10 YR $4 / 2$ and 10 YR 5/3 (very dark grayish brown to dark grayish brown and brown). The lighter colors can probably be attributed in part to increased calcium carbonate and ash content. The midden matrices ranged from a loose powdery texture which felt ashy to a more compact friable soif which. at times, had a distinctive "greasy" feel.

In addition to the buried burned rock middens, the B-horizon soils often contained two or more layers of subtle variations in color or texture within a single section of a profile. These differences can be attributed to occupational events at the site. The B-horizon solls contain the densest concentrations of occupation materials in most areas of the site. The thickest portions of this 1 ayer are usually associated with burned rock middens--a direct result of the addition of so much burned rock. Unfortunately, disturbances are common within the B-horizon. Comparatively few intact cultural features, with the exception of the burned rock middens, were recognized. Most of the cultural materials occurring with in the B-horizon can be attributed to Archaic occupations from Local Period 6 to Local Period 9, or rough 1 y 3000 B.C. to A.D. 700. The B-horizon soils, then, are archaeological sediments built up of 1 arge quantities of cultural materials and disturbed extensively during the occupational sequence.

\section{TRANSITION ZONE}

Beneath the B-horizon is a distinctive sol1 layer referred to in the field as the transition zone. This term was originally used because when first observed, this layer seemed to form a transition between underlying gravels and overlying B-horizon soils. The term transition zone, however, may be misleading; in some areas of the site, this layer was clearly distinct from the 1 ayers above and below. The transition zone typical $1 \mathrm{y}$ appears as a 1 ight brown to almost pink layer of compacted, calcareous, clay-rich silt comparatively free of rock. This 1 ayer ranges from 5 to $45 \mathrm{~cm}$ thick. 
reaching maximum thickness in a narrow band parallel to the bluff which runs through Areas $M$ and $I_{0}$ Munsel 1 readings ranged from $10 \mathrm{YR} 4 / 3$ to 5 YR $4 / 3$ (brown to reddish brown).

With one exception, the earliest occupation materials from 41 BX 228 consistently occurred within the transition zone. This layer appears to be the least disturbed cultural 1 ayer at the site. Several factors may have acted to protect the transition zone from disturbance. The higher clay content and increased compaction of this layer rendered it difficult to penetrate (troweling under dry conditions was very difficult), particularly in Area $M_{2}$ where the overlying thick burned rock midden protected the transition zone (Fig. 9,d). This soil 1 ayer would appear to result from both cultural and natural deposition. Fine silts and clays associated with low energy overbank flooding along with intensive cultural activities probably formed this layer on top of Pleistocene gravels. Gien Evans has suggested that the transition zone may have once extended across the site and was 1 ater eroded, leaving an "island" parallel to the bluff. However, a sign of an erosional surface was not observed. A more acceptable explanation may be that the transition zone is primarily a low energy overbank deposit (smal1 levee) which paral1e11ed the b 1 uff in a narrow band rather than spreading across the later site area.

\section{MINOR DEPOSITIONAL LAYERS}

A number of isolated depositional layers were al so observed at the site. Most of these occur in fringe areas of the site or underlying the cultural deposits. A brief description of some of these layers follow.

Qxidized Clay: A tightly compact reddish brown clay was observed in several filled-in runoff channels associated with the Pleistocene gravels (Fig. 4). The distinctive red color is probably a result of the oxidation of iron-rich clays.

Limestone Qutcrop: Eroded remnants of a 1 imestone outcropping were uncovered at the north end of the site. The rise or ridge visible between Area $A$ and BT 10 may be a reflection of the shape of this outcrop. The 1 imestone is one of the Cretaceous 1 imestones (possibly Buda Limestone) which outcrop in the area.

Caliche: Calcium carbonate occurring as small durable nodules, as a soft crumbly substance, and as a cemented conglomerate was observed in several areas of the site. These occurrences were described in the field as caliche. The small nodules occurring immediately above the gravels represent precipitated calcium carbonate formed by leaching of calcareous soils. The crumbly substance, which occurred directly above the limestone bedrock, is probab 1y decomposed 1 imestone (deteriorating bedrock). The third type of caliche occurred in a small area at the south end of the site (intersection of BT 1 and BT 8) in the upper gravel deposits. In this area, a grave1 conglomerate appears to have been formed by extreme leaching of the overlying shallow calcareous soils. The leached caliche has cemented the late Pleistocene gravels into a conglomerate. 


\section{MATERIAL CULTURE}

\section{LITHIC MATERIALS}

Lithic materials constituted the bulk of the culturally modified materials recovered from 41 BX 228. A11 1 ithic (stone) materials are described within the following major categories: chipped stone, nonchipped modified stone, and thermally fractured stone. The volume of 1 ithic material recovered during the 1979 season was much 1 arger than anticipated. Unmodified debitage (flakes, chips, and chunks) frequently totaled over 500 pieces per a $1=\mathrm{m}^{2} 10-$ $\mathrm{cm}$ level ( 0.1 cubic meter). Over 2800 chipped stone artifacts excluding modified and unmodified debitage were recovered. The quantity and variety of 1 ithic materials recovered precluded a complete analysis due to the fiscal constraints of the contract.

It was recognized at the outset of the 1 ithic analysis that al 1 ithic categories could not be dealt with in equal detail. Some categories such as "unmodified debitage" were on ly sampled. while others such as "distally beveled tools" were described in detai1. Emphasis was placed on the artifacts considered to be "finished" tool types. A finished tool type is defined as a morphologically distinct tool which is considered the completed product of a lithic reduction sequence. Additional emphas is was placed on the finished tool types which were most numerous and those which have been poorly or inconsistently defined in regional literature.

Perhaps the most important consideration of any 1 ithic analysis is the classification system or typological framework. Lithics are the most numerous cultural remains at most hunter and gatherer sites in Texas. Lithic typologies, specifically projectile point typologies, have formed the basis for the cultural chronologies on which much of our understanding of Texas prehistory hinges. Despite (or perhaps because of) their obvious importance and application to most hunter and gatherer sites, concepts of 1 ithic typology continue to vary widely across the state, as Skelton (1977) and others have noted. Attempts at devising a typological system which is logically consistent, applicable on at least a regional basis, and that can be duplicated by independent researchers have been almost nonexistent.

An exception is Nunley's (1971) "ideal typology," which has virtually been ignored by subsequent analyses. Nunley presents a logically consistent and flexible classification system that is capable of being duplicated by independent researchers. However, he fails to demonstrate that his system satisfies the criteria that he himse $1 f$ has defined as necessary to systematic classification. Nunley's "ideal typology" is based on intuitively derived rules which have not been shown to possess inherent cultural significance. The most inhibiting drawback of the "ideal typology" is that its validity or applicability have not been demonstrated by testing the system using outside and/or known data sets.

More typical in Texas 1 ithic analyses are descriptive typologies that utilize morphological, functional, or historical terminology. Functional terminology was especially prevalent in early publications such as those by Pearce (1919) and Jackson (1938). Functional terms such as knives, scrapers, and 
projectile points continue to be used today to a lesser extent. The problem with using such terms in 1 ithic typologies is that it is difficult in most cases to prove the assumed function without detailed wear pattern studies such as those by Keeley (1974). Tringman et a 1. (1974), Odel1 (1975), and Hayden (1979). More recent typologies replace most functional terms with morphological terms such as "blface" instead of "knife" and "uniface" instead of "scraper." Some functional terms such as "projectile point" remain in use.

Historical typologies combine morphological and functional considerations with distributional (spatial) and chronological (temporal) data. This approach is based on Krieger's (1944) typological concepts which culminated in the Handbook of Texas Archeology (Suhm and Jelks 1962), a revised version of Suhm, Krieger, and Jelks (1954). The Hamdbook provided a typology which, although based primarily on projectile points and pottery, could be applied to assemblages throughout the state. The Hamdook was never intended to be the final word on typology in Texas. Unfortunately. it has often been uncritically used to force projectile points into typological "pigeon holes." This has led to a number of we 11 mounded criticisms (see Nun ley 1971:55-57) and considerable controversy. This problem is further discussed in the section on projectile points.

Today most descriptive lithic typologies make use of a combination of functional, morphological, and historical concepts. However, many valid criticisms have been leveled at such typologies. To name but a few: (1) descriptive typologies frequently describe only a portion of the entire 1 ithic collection: (2) they rarely explain the purposes for which they are intended; (3) they frequently use undefined terminology inconsistently: and (4) because of the preceding problems, descriptive typologies tend to inhibit rather than promote communication between researchers.

Skinner (1971), Skelton (1977), Patterson (1977), and others have used technological attributes in combination with descriptive terminology to derive what Skelton (1977:140) ambitiously calls"... a more realistic understanding of the complexities of 1 ithic assemblages in Texas..." Basical1y, these technological approaches view 1 ithic reduction systems as a 1 inear process in which, to paraphrase Nun Tey (1971:66), 7 arger pieces of stone are reduced into smaller pieces. Technological typologies define a series of sequential stages, usually five or six in number, into which 1 ithic artifacts (mostly bifaces) are placed depending on which "stage" of the inferred manufacturing sequence they represent. The main problem inherent with this approach is that stage divisions of a 7 inear reduction process are often arbitrary (Collins 1975:16; Skelton 1977:142). Thus, while it may be easy to select ideal examples of any particular stage, it is very difficult in practice to define stages without having numerous border ine cases. Other problems with technological approaches include: (1) the fact that different tool types may follow significantly different manufacturing sequences; hence, the stage sequence may only be applicable to a narrow range of tool types; (2) the problem of deciding whether a given artifact at any stage has actually been used or not: and (3) the problem of distinguishing between flintknapping techniques, such as between "hard" and "soft" hammer percussion, on which a stage assignment may hinge. 
The cholce of which of the abovementioned classification systems or combinations thereof one uses must be based on one's purposes. The purposes of the classification system used in this analysis are four-fold: (1) to provide a consistent organizational framework: (2) to describe the consistencies and variations of the 1 ithic collection: (3) to facilitate comparisons with both previous and future classifications; and (4) to sort the artifacts into groups which potentially relate to cultural differences in function, time, and/or space.

The classification system used in this report is basically a descriptive typology that incorporates morphological, functional, and historical concepts. The lithics from 41 BX 228 are described within the following organizational framework or outline: Category, Class, Subclass, Group, Form. This organizational out 1 ine contains the minimum number of organizational levels necessary to define the most complex material category, that of chipped stone. Morphological considerations form the basis for most distinctions. Functional terms were incorporated into the outline on $1 y$ when very strong cases could be made for the accuracy of the term or in cases where that term had become traditional in regional 1 iterature. Despite the problems with the usage of historical and formal types, they have remained widely used in Texas archaeology and are critical to all cultural chronologies. Historical types were therefore incorporated with in the system at the Group or Form leve1. The formal types used were restricted to previously wel1-defined types or types for which the author had enough data to a 11 ow redefinition. Alphanumeric artifact codes and descriptive or formal type names were assigned to al1 artifact Groups or Forms. These should be considered merely as organizational and mnemonic labels unless specifically designated as formal type names.

\section{LITHIC RAM MATERIAS}

The 1 ithic assemblage from 41 BX 228 reflects the use of a relatively narrow range of raw material types, most of which are available in the immediate site area. Panther Springs Creek cuts through a variety of Cretaceous geologic formations upstream from the site, 1 ittering the stream bed with pebbles, cobbles, and boulders of various sedimentary rocks. The specific 1 ithic material types utilized at 41 BX 228 include 1 imestone, chert, chalcedony, quartz, quartzite, hematite, sandstone, calcite, dolomite, graphite schist, and one unidentified metamorphic rock. Of these, 1 imestone and chert account for over $99 \%$ of the 1 ithic material recovered from the site. A brief description of each 1 ithic material type, its source area, and usage for artifacts is presented below.

\section{Limestone}

Limestone is a calcium carbonate rock which occurs as gravels and cobbles in the terrace deposits underlying the site, as exposed bedrock at the north end of the site, and as stream bed deposits al 1 along Panther Springs Creek. Most of the 1 imestone utilized by the occupants of the site was probably obtained from the latter source: cobbles littering the stream bed. 
Limestone is general1y white when freshly exposed, but is often stained orange in iron-rich soils. Heat-fractured 7 imestone is gray and frequentiy has red to pink discolorations.

Limestone was primarlly used in fire-related activities such as 1 ining firehearths and quite possibly as boiling stone material. Oblong cobbles approximately $10-25 \mathrm{~cm}$ in maximum diameter were used for these activities. In addition, limestone was used to manufacture certain tool types, including grinding slabs, grinding basins, manos, incised stones, and occasionally hammerstones. Limestone tools may have been more numerous than were recognized, but the soft material weathers easily, obscuring modification or use-wear patterns.

\section{Chact}

Chert, or flint as it is commonly known, is a cryptocrystalline quartz with conchoidal fracturing properties that make it an ideal material for making chipped stone tools. Chert occurs along with 1 imestone as pebbles, cobbles, and boulders in the underlying terrace deposits and in the stream bed deposits adjacent to the site. The chert found in the site vicinity is derived from the Edwards Limestone formation upstream from the site. Typically, the Edwards chert ranges in color from tan to light gray and less commonly dark gray, dark brown. or white. The exterior cortex is usually quite hard and brown to off-white, but sometimes grades into a softer 1 imestone when thick. Chert cobbles in Panther Springs Creek most frequent $1 \mathrm{y}$ have rounded, irregular shapes and less frequently spherical, oblong, and rounded tabular shapes. Edwards cherts range widely in flaking characteristics. Fine-grained, homogeneous, and transiucent cherts provide the most predictable flaking materials and are referred to as high quality cherts. Cherts that are coarse or variably grained, opaque, and marred by flaws are poor choices for $f l$ aking and are referred to as poor quality cherts. The flaws are often numerous and include fossils, bedding planes, calcite-filled inclusions, voids (hollow places), and highly variable grain size. High quality cherts are much less common and usually occur in the more regular cobble shapes. Poor quality cherts, on the other hand, are common and usually occur in irregular cobble shapes. In addition to these two extremes, many cherts have intermediate characteristics.

Chert was used extensively by the inhabitants of 41 BX 228 for chipped stone tool making throughout the occupation history of the site. An examination of the various chert tool and debitage categories suggests that the high quality cherts were selectively chosen as preferred flintknapping material in reverse proportion to their availability. Manufacturing failures were more common in the poor quality cherts for obvious reasons. Heat treatment was used to improve the flaking characteristics of Edwards cherts, as will be 1 ater discussed. 


\section{Chalcedony}

Chalcedony is a term used to describe a cryptocrystalline quartz related to chert which occurs rarely in the area in pebble or cobble form. Translucent white chalcedony is sometimes colloquially referred to as "moonstone." Several chalcedony $f l$ akes and tool fragments were recovered from $41 \mathrm{BX} 228$, indicating its occasional use as a chipped stone tool material.

\section{Duactz and Ouactz ite}

Quartz is a silicate mineral that occurs in various crystal forms, while quartzite is a metamorphosed quartz sandstone. Neither occurs in the immediate site area. Quartzite, however, occurs common $7 y$ in recent or remnant gravel deposits of many major rivers in the region, including the San Antonio and the Guadalupe Rivers; hence, a specific source area cannot be pinpointed. The quartzite from $41 \mathrm{BX} 228$ is dark red to 7 ight gray. Quartz does not occur in primary contexts in the San Antonio area. The most 1 ikely source area for the quartz from $41 \mathrm{BX} 228$ is the Llano Up 7 ift region some 60 miles north of Bexar County. The quartz recovered from 41 BX 228 appears to be "milky quartz," a transiucent to transparent white variety. Both quartz and quartzite were found on $7 y$ as occasional flakes or chips. No tools or tool fragments of these materials were found, suggesting that they constitute a very minor raw material.

\section{Henat ite}

Hematite is an iron oxide mineral that occurs commonly in the immediate site area. Several other related iron minerals such as goethite and 1 imonite also occur in the area and may be difficult to distinguish from hematite. Hematite occurs in both hard and soft forms. Hard hematite has rounded shapes (spherical, botryoidal, and mammillale forms), with a dark brown or rust color. The soft form of hematite is called red ochre. Red ochre is actually natural pulverized hematite mixed with impurities. Depending on the exact mix of impurities, red ochre may be bright red and crumbly or dark red and compact. Red ochre, which has a long history of use in prehistoric and historic societies as a paint pigment, occurs at 41 BX 228 as small fragments, some of which show wear facets or scratch marks. Hard hematite specimens from $41 \mathrm{BX} 228$ are apparent7y unmodified and may have been brought to the site as curiosity items.

\section{Sandstone}

Sandstone is a sedimentary rock composed of cemented sand grains. Sandstone occurs rarely, if at al1, in the immediate site area. Most of the sandstone found at $41 \mathrm{BX} 228$ is ferruginous (1ron-bearing) sandstone which appears red to dark brown or rusty colored. Both fine-grained and very coarse-grained sandstones were occastonal1y used by the occupants of 41 BX 228 to make grinding implements. The rarity of these sandstone artifacts at $41 \mathrm{BX} 228$, however, reflects the general 1 ack of sandstone in the immediate site area. 
Its source area is impossible to pinpoint, as sandstone can be found along many area stream courses. particularly to the south or east, but rarely to the north or west.

\section{Calcite}

Calcite is the chief mineral component of 1 imestone and al so occurs in various crystal forms in the area. Rhombohedral and fibrous aggregate forms of calcite were found at 41 BX 228. These crystals show 1 ittle or no usewear and may have been introduced to the site as curiosity items.

\section{Dolomite}

Dolomite is a calcium carbonate which forms through replacement of some of the calcium in limestone by magnesium (Hurlbut and Klein 1977:309). Ankerite, closely related to dolomite, has iron as the replacement element instead of magnesium. Several ground and pecked artifacts from 41 BX 228 are made of a material similar to 7 imestone, yet noticeably harder and denser with a buff to yellow color. This material is probably dolomite or ankerite or a partial combination of one of these minerals and calcite. Some specimens seem to grade into 1 imestone. Some of the fire-fractured rock that constitutes a burned rock midden may also be dolomite or ankerite rather than 1 imestone.

\section{Graphite Schist}

Graphite schist is a relatively soft metamorphic rock with a gray blue color. Several small fragments which appear to be graphite schist were found at 41 BX 228. One of the 41 BX 228 graphite schist specimens is shaped by usewear facets, perhaps from use as a paint pigment. The nearest source of graphite schist is the Llano Uplift region.

\section{Unidentified Metamarphic Rack}

A single grooved and battered artifact was found that appears to be made from some type of metamorphic rock containing igneous minerals. This rock type is definitely foreign to the site. Once again, the most likely source area is the Llano Uplift region.

\section{HEAT TREATMENT OF CHERT}

The improvement of siliceous lithic materials (in this case, chert) through gradual and prolonged application of indirect heat is known as heat treatment, thermal alteration, or annealing. A relatively 1 arge body of 1 iterature has been devoted to heat treatment, $e_{\circ} g_{0}$ in ethnographic accounts and discussions of experimental replication and flake characteristics, etc. (see Crabtree and Butler 1964; Purdy and Brooks 1971; Hester 1972; Skelton 
and Meridith 1977). It is now recognized that prehistoric heat treatment of siliceous materials was a very widespread practice through time and space in North America (Hester and Collins 1974; Epstein 1979). Heat treatment improves the flaking properties of siliceous materials by relieving internal stresses and strains, thus, making the material more elastic without being brittle (Crabtree 1972:5). Heat-treated material becomes more vitreous and forms sharper edges; the glassy texture and greater elasticity result in easier knapping with greater control ( $\left.1 \mathrm{~b} / \mathrm{d}_{0}\right)$.

A complex variety of factors govern the changes that occur in any given 1 ithic material as the result of heat treatment. In general one or more of the following changes can be expected in heat-treated chert: (1) a change in color to a darker and/or redder (or purplish) color; (2) a change to a waxy or greasy texture; and (3) a change in appearance to a vitreous (glassy) luster of all flaked surfaces except relic surfaces existing prior to heat treatment (Hester and Collins 1974; Ske1ton and Meridith 1977). A combination of some or all of the above changes were observed on many of the chert artifacts from $41 \mathrm{BX} 228$. Casua 1 heat treatment experiments on Edwards chert collected from northern Bexar County resulted in similar changes. It should be noted that, while some archaeological specimens showed definite evidence of heat treatment, others showed only slight indications of change (i.e., slight luster or slightly waxy texture). In general, the thinner, more carefully worked artifact categories evidenced higher frequencies of heattreated chert. No attempt was made to quantify these frequencies, although relative impressions are noted where appropriate throughout the following section.

\section{CHIPPED STONE}

\section{Cores}

Cores are the remaining portion of a chert cobble after flakes have been removed. Crabtree (1972:54) defines a core "as a mass of material often preformed by the worker to the desired shape to allow the removal of a definite type of flake or blade. Piece of isotropic material bearing negative flake scars or scar." Flakes are intentionally removed from cobbles for three reasons: (1) to be used as unaltered tools or further reduced into bifacial and unifacial tool forms ( $f 1$ ake too 1s); (2) to reduce the parent mass into a tool (core tool); or (3) to test a cobble to determine chert flaking characteristics (tested cobble).

Cores form one of the 1 argest 1 ithic classes by count and especially by weight at $41 \mathrm{BX} 228$. They occur at all levels in virtually al1 areas of the site. Cores reflect less variation in chert color and quality than many of the thin bifaces and projectile points. Virtually all core material could have been derived directly from the adjacent creek bed. The absence of darkened and reddened colors, glossy sheen, and superior flaking characteristics suggests that cores were not heat treated.

Most core groups have irregular asymmetrical shapes that do not provide a standard orientation for the purpose of length-width-thickness measurement. 
The fact that cores are by definition a by-product of flake production and not an end-product suggests that length-width-thickness measurements and relative ratios have 7 ittle if any cultural significance. Nonetheless, it was felt that a general size range should be indicated. In an attempt to rapidly divide the cores into size groups the following procedure was used. Three circles having diameters of $5 \mathrm{~cm}, 7.5 \mathrm{~cm}$, and $10 \mathrm{~cm}$ were cut into a piece of particle board. The cores were then fitted into the smallest hole possible, thus sorting the cores into four minimum diameter size groups $(1=\langle 5 \mathrm{~cm} ; 2=5-7.5 \mathrm{~cm} ; 3=7.5-10 \mathrm{~cm} ;=>10 \mathrm{~cm})$. Al1 cores were also weighed to the nearest gram. Metric data are summarized in Table 2.

Cores seldom receive the same careful attention accorded to other chipped stone artifacts. One reason for this is obvious: most cores are amorphous in shape and lack apparent patterning. An exception to this statement are the distinctive polyhedral blade cores often described in detail (see Hester and Shafer 1975). Consequently, the attributes most often used to sort cores into groups are platform types and direction of flake removal (Hall, Black. and Graves 1982; Ske1ton 1977: Hester 1975b). Similar attributes were used to sort the 41 BX 228 cores.

As previously discussed, the chert occurring in Panther Springs Creek is frequently flawed by bedding planes, fossils, cavities, quartz inclusions, and variable grain size. These features often cause irregular cleavages which mask platforms and percussion bulbs. Some cores were covered with massive step fracturing that often prohibited determination of sorting attributes. Using platform type and flake removal directions as attributes for core sorting injects a substantial degree of subjectivity into the process. The ability to recognize these attributes is dependent on one's experience and familiarity with flintknapping, and borderline cases are numerous. Another factor to consider is that most of the cores are the discarded remains of a much larger cobble. Techniques used to remove the initial $f 1$ akes may have been patterned, but the recovered artifact is the remaining mass after the core became so small and irregular that no useful flake could be removed.

The majority of the cores from $41 \mathrm{BX} 228$ have multidirectional flake removals and 1 ack apparent patterning. Platforms include natural (cortex), single facet prepared, and multifacet prepared. It appears that the selection of $f 1$ ake platforms was fortuitous; $1 . \theta_{0}$, the knappers chose whatever platform would produce a flake.

Cores were divided into the following six groups:

C1. Group 1 - Natural Platform

C2. Group 2 - Unidirectional Prepared Platform

C3. Group 3 - Bidirectional, Natural and Prepared Platforms

C4. Group 4 - Multidirectional

C5. Group $5-$ Bifaclal

C6. Group 6 - Core Fragments 
TABLE 2. CORE METRIC DATA

\begin{tabular}{|c|c|c|c|c|c|}
\hline \multirow{2}{*}{$\begin{array}{c}\text { Core } \\
\text { Group:Form }\end{array}$} & \multirow{2}{*}{$\begin{array}{l}\text { Number of } \\
\text { Specimens }\end{array}$} & \multirow{2}{*}{$\begin{array}{c}\text { Size } \\
\text { Group* }\end{array}$} & \multicolumn{3}{|c|}{ Weight $(g)$} \\
\hline & & & Minimum & Maximum & Mean \\
\hline $\mathrm{Cl}$ & $\begin{array}{r}4 \\
14 \\
5\end{array}$ & $\begin{array}{l}1 \\
2 \\
3\end{array}$ & $\begin{array}{r}86 \\
128 \\
413\end{array}$ & $\begin{array}{l}117 \\
306 \\
828\end{array}$ & $\begin{array}{l}100 \\
222 \\
594\end{array}$ \\
\hline $\mathrm{C} 2$ & $\begin{array}{r}6 \\
25 \\
8 \\
1\end{array}$ & $\begin{array}{l}1 \\
2 \\
3 \\
4\end{array}$ & $\begin{array}{r}20 \\
117 \\
257 \\
837\end{array}$ & $\begin{array}{l}127 \\
549 \\
825 \\
837\end{array}$ & $\begin{array}{r}80 \\
220 \\
489 \\
837\end{array}$ \\
\hline $\mathrm{C} 3: 1$ & $\begin{array}{l}1 \\
9 \\
6 \\
2 \\
7\end{array}$ & $\begin{array}{l}1 \\
2 \\
3 \\
4 \\
-\end{array}$ & $\begin{array}{r}123 \\
102 \\
334 \\
1133 \\
296\end{array}$ & $\begin{array}{r}123 \\
465 \\
705 \\
1316 \\
825\end{array}$ & $\begin{array}{r}123 \\
210 \\
525 \\
1224 \\
468\end{array}$ \\
\hline $\begin{array}{l}C 4: 1 \\
C 4: 2 \\
C 4: 3 \\
C 4: 4 \\
C 4: 5\end{array}$ & $\begin{array}{r}72 \\
148 \\
32 \\
4 \\
10\end{array}$ & $\begin{array}{l}1 \\
2 \\
3 \\
4 \\
-\end{array}$ & $\begin{array}{r}21 \\
56 \\
189 \\
474 \\
36\end{array}$ & $\begin{array}{l}161 \\
415 \\
676 \\
796 \\
540\end{array}$ & $\begin{array}{r}67 \\
169 \\
375 \\
626 \\
252\end{array}$ \\
\hline $\mathrm{C} 5$ & $\begin{array}{l}6 \\
5\end{array}$ & $\begin{array}{l}2 \\
3\end{array}$ & $\begin{array}{l}137 \\
201\end{array}$ & $\begin{array}{l}378 \\
471\end{array}$ & $\begin{array}{l}239 \\
383\end{array}$ \\
\hline c6 & $\begin{array}{r}23 \\
16 \\
4\end{array}$ & $\begin{array}{l}1 \\
2 \\
3\end{array}$ & $\begin{array}{r}18 \\
81 \\
257\end{array}$ & $\begin{array}{l}119 \\
213 \\
998\end{array}$ & $\begin{array}{r}62 \\
143 \\
509\end{array}$ \\
\hline
\end{tabular}

*Minimum diameter: $I=<5 \mathrm{~cm}, 2=5-7.5 \mathrm{~cm}, 3=7.5-10 \mathrm{~cm}, 4=>10 \mathrm{~cm}$ 
A11 descriptive headings include group or form number, group or form name (if assigned), alphanumeric artifact code, and number of specimens. No illustrations are provided for the core groups.

\section{Group 7 - Natural Platfortin (23 specimens)}

Group 1 cores contain cobbles retaining much of the cortex $(45-95 \%)$ and having a small number of $f 1$ akes (one to $s(x)$ removed from natural (cortex) platforms. "Tested" cobbles (one or two flakes removed, presumably to "test" the chert quality) are included in this group. The outline shapes are general1y irregular. Flakes have been removed both unidirectionally and multidirectionally. Most flakes originate from relatively flat portions of the cobble; i.e.s that corner or edge offering a good platform.

\section{C2. Group 2 - Unidirectional Prepared Platform (40 specimens)}

Group 2 cores have $f 1$ akes removed from a common prepared $p 1$ atform. Most platforms were single faceted but occasional multifaceted platforms occur. A11 flakes were removed in one direction with respect to the platform. Some specimens appear to represent split cobbles with the halved surface used as a striking platform. Most specimens were made by striking a cobble at one end, then reversing the direction, and using the first flake scar as a platform for subsequent $f 1$ akes. On most Group 2 cores a series of $f 1$ akes have been removed en echelon. leaving overlapping flake scars. One specimen resembles a crude polyhedral core, although the flake scars do not indicate that blades were removed.

\section{C3. Group 3 - Bidirectional, Matural and Prepared Platforms (25 specimens)}

Group 3 cores have flakes removed from opposite directions al ong a shared edge. Flake removal may occur along one end, one side, one end and one side, or one end and two sides, but the other end al ways remains unmodified cortex (cortex covered). The unmodified end gives the core a "backed" appearance, giving rise to the generally misleading 7 abel "chopper," which is often applied to similar cores. Platform types include natural platforms for initial flake removal and prepared platforms for subsequent removals. Both single faceted and multifaceted prepared platforms occur. Flakes struck from one direction serve as platforms for flakes struck in the opposite direction. Several specimens do have edge modifications that suggest possible use.

C3:le_form 1 (18 specimens)

A11 of Group 3 cores except Form 2 - Possible Tools is included with in this form. 


\section{C3:2e Form 2 - Possible Tools (7 specimens)}

Five Group 3 cores have edge modifications that suggest possible use as tools. Three specimens have relatively steep working edges formed by minute unifacial retouch and are similar to unifacial tools. These possibly functioned as scraping tools. Heavy battering along the flaked side of one specimen has step fractured and rounded the edge, suggesting possible use as a chopping tool. Another Form 2 specimen has been shaped into a narrow point somewhat similar to a crude handaxe.

\section{C4. Group 4 - Muttidirectional (266 specimens)}

Multidirectional cores have flakes removed from two or more nonshared platforms. This group is by far the largest core group. Platform types include natural, single facet prepared, and multifacet prepared. This group was initially sorted into two groups m-those with natural and single facet platforms and those with natural, single, and multifaceted platforms. This proved difficult because of flake scars running in many directions on most specimens. These scars often concealed platform preparation; i.e.s it was unclear whether the platform was multifaceted before or after a given flake was removed. Since it is believed that the two categories could not be accurate 1 y rep 1 icated and the aboriginal knappers probab 1 y used whatever platform was available on multidirectional cores, such a division is irrelevant.

Various other attributes were considered to divide this large group into smaller groups. Shapes included blocky, pyramidal, round, and irregular with little or no apparent patterning. Cortex was present on many specimens, but the amount of cortex did not seem to correlate with size or shape. The forms below are based on size and may have little cultural relevance.

\section{C4:1. Form 1 - Minimum diameter $<5 \mathrm{~cm}$ (72 specimens)}

The cores in Group 4, Form 1 could be 1 abeled "exhausted cores" or "core nuclei." These smal1 multidirectional cores have few platforms remaining from which a useful flake could be removed.

C4:2. Form 2 - Minimum diameter $5 \mathrm{~cm}-7.5 \mathrm{~cm}$ (148 specimens)

Many of these Group 4, Form 2 cores could be described as exhausted cores.

C4:3. Form 3 - Minimum diameter $7.5-10 \mathrm{~cm}$ (32 specimens)

C4:4. Form 4 - Minimum diameter $>10 \mathrm{~cm}$ (4 specimens)

C4:5. Form 5 - Possible Core Tools (10 specimens) 


\section{C5. Group 5 - Bifacial (11 specimens)}

Bifacial cores have flakes removed bidirectionally from a shared edge around al1 or most of the circumference. The distinction between bifacial cores and thick bifaces is that the flake patterning on bifacial cores suggests flake production rather than shaping. This distinction is admittedly subjective; some of the bifacial cores may well be early stages of bifacial reduction. However, most Group 5 cores have irregular thick shapes which would seemingly prohibit thinning. Group 5 cores have a generally flat, two-sided appearance with broad oval, triangular, and rectangular outlines. Cortex patches are present on some specimens but usually cover less than $20 \%$ of the surface area. Large, broad flake scars cover one or both faces. Platforms include natural, single facet prepared, and multifacet prepared.

\section{C6. Group 6 - Core Fragments (43 specimens)}

Group 6 cores include core trimming flakes, obvious core fragments, and shattered core segments which are not classifiable into the above groups. Many core fragments bear positive flake scars showing removal from parent mass.

\section{Unimadified Lithic Debitage (Courtenay J. Jones)}

A total of over $231 \mathrm{~kg}$ of unmodified, unburned 1 ithic debitage was recovered from major excavation units and sondage test units at 41 BX 228 during the 1979 season. This weight total is estimated to represent 219,000 individual pieces of debitage. Project 1 imftations did not permit an analys is of the total debitage sample. Instead, nine $1 \mathrm{~m}^{2}$ units were selected for a detailed analysis. The nine units selected had between 7 and 11 levels each, were comparatively undisturbed, and were distributed across the site. The primary purpose of the analysis was to identify the 1 ithic reduction techniques employed at the site. In addition, the resulting data provides some basis for a comparison of horizontal and vertical intrasite distribution patterns. This study was originally prepared as an undergraduate anthropology project at The University of Texas at San Antonio under the direction of Dr. T. R. Hester (Jones 1980).

The nine $1-m^{2}$ test units studied are identified as Areas $D, E, F, G, H, I$, and $J$ and units E1005 N929 and E1010 N940. Each area was excavated in arbitrary 10-cm levels. All excavated matrix was passed through a 1/4-inch wire mesh screen. The resulting debitage was recovered and bagged according to unit and level. During the initial 1aboratory processing and cataloging phase, all artifacts, cores, and modifled flakes were removed for separate studies. The remaining chert debitage is the subject of this analysis.

Debitage can be defined as the waste products of 1 ithic reduction processes. In other wordss debitage consists of the pieces of 1 ithic material removed from the parent mass (core or unfinished tool) during the manufacture of formal tools such as bifaces. Pieces of unmodifled debitage lack the retouch or edge damage that characterizes pleces of debitage that have been used as 
informal tools (modified debitage). Each bag of debitage was divided into four groups: flakes (with platforms), chips (flake fragments lacking platforms), chunks, and burned chert. The chips were further divided into corticate and decorticate classes. Flakes were initially sorted into primary, secondary, and tertiary flake types according to the characteristics they exhibited (see Appendix III for definitions of 1 ithic terminology). These flake types were further examined and sorted according to p 1 atform characteristics. Raw frequencies and weight totals were recorded in the appropriate category on the laboratory analysis form (see Appendix II, Fig. 60).

Platform categories for the three flake types vary slightly because not all types of $p l$ atforms were expected in each flake class. The tertiary flake class does not contain a cortex platform category, because a tertiary flake, by definition, does not retain any cortex. The primary flake class does not contain 1 ipped or multifaceted platform categories, because it was believed that these characteristics would not be associated with primary flakes. During the analysis no primary flakes with 1 ipped platforms were recorded, and the very smal1 number of multifaceted platforms observed were included with the single facet platforms. This number was too sma 11 to warrant a separate category, and its inclusion in the single facet category had a negligible effect on the results.

The platform categories were further subdivided into sma 11 (those with platforms less than $1 \mathrm{~cm}$ in width) and 1 arge (those with platforms $1 \mathrm{~cm}$ or larger in width). This division was made to offer some insight into the degree of precision achieved by the flintknappers. The $1 \mathrm{~cm}$ figure has been used by Grant D. Hall (Ha.11, B1ack, and Graves 1982:364) in his study of the debitage recovered from the Choke Canyon project in south Texas. This conformity may be useful if intersite studies are to be accomplished in the future. Categories for each level were then independently recorded by count and weight on a flake analysis form designed to facilitate computer coding (see Appendix II, Fig. 62). A11 data were placed in the project computer data files.

\section{Platform Categories}

The following abbreviations are used in this analysis to identify the platform categories:

$$
\begin{aligned}
& \text { SCP }=\text { Sma11 Cortex Platform } \\
& \text { LCP }=\text { Large Cortex Platform } \\
& \text { SSFP }=\text { Sma11 Single Facet Platform } \\
& \text { LSFP }=\text { Large Single Facet Platform } \\
& \text { SMFP }=\text { Sma11 Multifacet Platform } \\
& \text { LMFP }=\text { Large Multifacet Platform } \\
& \text { SLPF }=\text { Sma11 Lipped Platform } \\
& \text { LLPF }=\text { Large Lipped Platform }
\end{aligned}
$$

To qualify as a cortex platform, the platform had to exhibit cortex although not necessarily over the entire platform. This latitude was permitted since 
sma 11 chips can shatter from the 1 atform when $f 1$ akes are removed. This phenomena is especially apparent in hard hammer percussion; the reader is referred to Crabtree (1972) and to Tixier (1974) for further information. Single facet platforms exhibit no signs of platform preparation or cortex. The surface of the platform extends from one side of the platform to the other in an unbroken plane. A multifaceted platform exhibits some form of platform preparation, including faceting, beveling, abrading, or grinding. A 1 ipped platform may or may not exhibit platform preparation, but does possess a distinct ridge or extension of the platform which overhangs the ventral surface of the flake.

\section{Platform Variations}

A platform area may be a natural or prepared flat surface to receive and withstand the applied force. The platform can be made by removing a flake, or flakes, or can be prepared by abrasion, by creating the proper angle by pressure or percussion or by removing the overhang (Crabtree 1972:12).

In the lithic reduction process various stages or phases can be identified. Katz (1976:104) identified six stages: stages 1-3 use the hard hammer technique; stage 4 uses the soft hammer technique; and stages 5 and 6 , which he identifies as the finishing or maintenance stages, employ pressure flaking. Shafer (1976a:9) identifies three comparable stages: hard hammer, soft hammer, and pressure flaking.

The platform characteristics associated with soft and hard hammer techniques are readily distinguishable and serve as the basis for most of this analysis. Platforms resulting from hard hammer activity are distinguished by one or more of the following characteristics: 1ittle platform preparation, cortex on the platform, and large, thick platforms which sometimes reveal evidence of crushing. These characteristics are discussed in Crabtree (1972:11), Shafer (1973:92), and Muto (1971:57, 63, 67). Soft hammer techniques resu1t in $\mathrm{p} 1$ atforms which are prepared either by faceting, grinding, or abrading; frequently the platforms are 7 ipped. These platforms are general1y sma $11 \mathrm{er}$ in length. width, and thickness than platforms associated with hard hammer activities. Soft hammer platforms often show signs of marginal retouch. These characteristics are discussed in Crabtree (1972:9, 12), Shafer (1973:67, 68, 116, 129; 1976a:9), and Skinner (1971:159). These differences in platform characteristics serve as the basis for identifying hard hammer activity from soft hammer activity.

It is more difficult to distinguish between soft hammer activity and pressure flaking which produces flakes that often possess the same characteristics as soft hammer flakes. Both Shafer (1976a:9) and Crabtree (1972:15) discuss this problem. Since pressure flaking is primarily used when the demand for control and precision is at its highest, i.e.s artifact resharpening and final shaping (Crabtree 1972:14-16), it would seem that flake size could be considered in differentiating between the two methods. However, there are limiting factors which must be considered in using flake size as the distinguishing criteria. Measuring the dimensions of each flake would be extremely 
time consuming and infeasible for most projects which operate under various time and fiscal constraints. Data published by Gunn. Mahula, and Sol 1berger (1976:3) in an analysis of the debitage recovered from the Sol 1berger experiment was more useful in this analysis. The Sollberger experiment involved the manufacture of a large stemmed thin biface under controlled conditions. When the total debitage collected from a drop cloth was passed through a series of increasingly finer mesh screens, an $80 \%$ oss of platform flakes occurred through 1/4-inch mesh screen. The majority of this $80 \% 10$ ss consisted of the smaller pressure flakes. Since 1/4-inch mesh was used in the field excavation of 41 BX 228, a similar loss ratio could be expected. On this basis, then, pressure flaking activity was not considered in this analysis.

\section{Results}

The debitage analyzed totaled 44,109 pieces from the nine tested units. Gross count and weight figures are presented in Table 3.

Burned Chert: The burned chert comprised 32.4\% of the total debitage recovered; the area count and weight figures are 1 isted in Table 4.

Chunks: The chunks comprised 1.1\% of the analyzed debitage; the area count and the weight figures are listed in Table 5.

Chips: The chips totaled 3194 corticate fragments and 19,457 decorticate fragments for a combined total of 22,651 fragments, or $47 \%$ of the debitage analyzed. This was the largest group in the study. The count and weight figures for this group are presented in Table 6 .

Corticate chips accounted for $14.1 \%$ by count of the total chips, while decorticate chips accounted for the remaining $85.9 \%$.

Elakes: The flakes (primary, secondary, and tertiary) totaled 6616 and accounted for 17\% of the total debitage analyzed. Count and weight figures are presented in Table 7. Raw data on flake distribution are on file at the CAR-UTSA.

The results of this analysis indicate that soft hammer percussion was the dominant activity during the occupation of this site and that very 1 ittle hard hammer activity occurred. This is evidenced by several factors. First, the primary, secondary, and tertiary flake totals for the nine areas reveal that a high percentage of tertiary flakes were recovered from each area. These totals are presented in Table 8.

A useful comparison with other sites such as $41 \mathrm{BX} 271,41 \mathrm{CM} 86$, and $41 \mathrm{KE} 49$ ( $\mathrm{Kel} 1$ y 1975) can be made ( $\mathrm{Table} \mathrm{9)}$ when these total counts are converted to percentages (Table 10). Kelly (fbid.) stated that quarry sites should have a higher percentage of primary and secondary flakes as compared to tertiary flakes. Sites in which final retouch or resharpening occurred would have few primary $f 1$ akes but would have a higher percentage of tertiary flakes. Kelly compared 41 CM 86, a quarry site, with two other sites (see 
TABLE 3. WEIGHT AND COUNT OF UNMODIFIED DEBITAGE

\begin{tabular}{ccccc} 
Area & Count & $\begin{array}{c}\text { Percentage } \\
\text { of Total }\end{array}$ & Weight $(\mathrm{g})$ & $\begin{array}{c}\text { Percentage } \\
\text { of Total }\end{array}$ \\
\hline D & 4666 & 10.6 & 4831 & 9.9 \\
E & 6172 & 13.9 & 6233 & 12.8 \\
F & 3568 & 8.0 & 4985 & 10.3 \\
G & 6245 & 14.2 & 6378 & 13.1 \\
H & 5458 & 12.4 & 6507 & 13.4 \\
I & 7090 & 16.1 & 7397 & 7.9 \\
J & 3683 & 8.3 & 3854 & 9.9 \\
E1005 N929 & 4547 & 10.3 & 3804 & 7.4 \\
E1010 N940 & 2680 & 6.1 & 3578 & -15 \\
\hline \\
\hline
\end{tabular}

TABLE 4. WEIGHT AND COUNT OF BURNED DEBITAGE

\begin{tabular}{ccccc} 
Area & Count & $\begin{array}{c}\text { Percentage } \\
\text { of Total }\end{array}$ & Weight $(g)$ & $\begin{array}{c}\text { Percentage } \\
\text { of Total }\end{array}$ \\
\hline D & 1466 & 10.2 & 1025 & 6.8 \\
E & 1578 & 11.0 & 1634 & 10.9 \\
F & 1582 & 11.0 & 2467 & 16.4 \\
G & 2387 & 16.7 & 2276 & 15.1 \\
H & 1926 & 13.4 & 1989 & 13.2 \\
I & 2224 & 15.5 & 2010 & 13.4 \\
J & 1223 & 8.5 & 1250 & 8.3 \\
E1005 N929 & 1197 & 8.4 & 1234 & 7.8 \\
E1010 N940 & 745 & 5.2 & 1170 & 100.1 \\
\hline
\end{tabular}


TABLE 5. FREQUENCY OF LITHIC CHUNKS

\begin{tabular}{ccccc} 
Area & Count & $\begin{array}{c}\text { Percentage } \\
\text { of Total }\end{array}$ & Weight $(\mathrm{g})$ & $\begin{array}{c}\text { Percentage } \\
\text { of Total }\end{array}$ \\
\hline D & 59 & 11.5 & 439 & 8.2 \\
E & 86 & 16.7 & 373 & 7.0 \\
F & 53 & 10.3 & 573 & 10.7 \\
G & 77 & 15.0 & 680 & 12.7 \\
H & 37 & 7.2 & 599 & 11.2 \\
I & 78 & 15.2 & 920 & 17.2 \\
J & 58 & 11.3 & 418 & 11.8 \\
E1005 N929 & 31 & 6.0 & 637 & 13.3 \\
E1010 N940 & 35 & 6.8 & 713 & 100.0 \\
\hline
\end{tabular}

TABLE 6. FREQUENCY OF LITHIC CHIPS

\begin{tabular}{cccrr} 
Area & Count & $\begin{array}{c}\text { Percentage } \\
\text { of Total }\end{array}$ & Weight $(\mathrm{g})$ & $\begin{array}{c}\text { Percentage } \\
\text { of Total }\end{array}$ \\
\hline D & 2177 & 9.6 & 1506 & 10.4 \\
E & 3418 & 15.1 & 2062 & 14.2 \\
F & 1483 & 6.5 & 920 & 6.3 \\
G & 2807 & 12.4 & 1540 & 10.6 \\
H & 2761 & 12.2 & 2132 & 14.7 \\
I & 3787 & 16.7 & 2569 & 17.7 \\
J & 1838 & 8.1 & 1011 & 7.0 \\
E1005 N929 & 2799 & 12.4 & 1758 & 7.0 \\
E1010 N940 & 1581 & 7.0 & 1012 & 12.1 \\
\hline
\end{tabular}


TABLE 7. FREQUENCY OF DEBITAGE: FLAKES

\begin{tabular}{crrrr} 
Area & Count & $\begin{array}{c}\text { Percentage } \\
\text { of Total }\end{array}$ & Weight $(\mathrm{g})$ & $\begin{array}{c}\text { Percentage } \\
\text { of Total }\end{array}$ \\
\hline D & 964 & 14.6 & 1861 & 13.6 \\
E & 1090 & 16.5 & 2164 & 15.9 \\
F & 450 & 6.8 & 1025 & 7.5 \\
G & 974 & 14.7 & 1882 & 13.8 \\
H & 734 & 11.1 & 1787 & 13.1 \\
I & 1001 & 15.1 & 1898 & 8.9 \\
J & 564 & 8.5 & 1175 & 8.6 \\
E1005 N929 & 520 & 7.9 & 1175 & 5.0 \\
E1010 N940 & 319 & 4.8 & 683 & 100.0 \\
\hline
\end{tabular}

TABLE 8. TOTAL COUNT OF PRIMARY, SECONDARY, AND TERTIARY FLAKES

\begin{tabular}{cccc} 
Area & Primary & Secondary & Tertiary \\
\hline D & 12 & 177 & 775 \\
E & 19 & 183 & 888 \\
F & 10 & 91 & 349 \\
G & 18 & 205 & 751 \\
H & 13 & 120 & 601 \\
I & 12 & 138 & 851 \\
J & 6 & 153 & 405 \\
E1005 N929 & 7 & 51 & 432 \\
E1010 N940 & 9 & 57 & 253 \\
\hline \multirow{2}{*}{ TOTAL } & 106 & 1205 & 5305
\end{tabular}


Table 9). A 1979 analysis of a second excavation at 41 BX 271 (Jones, Foster, and Kunnert 1979) revealed the following ratio: 5:20:75. The nine areas in the present analysis have ratios comparable to a11 of these except for $41 \mathrm{CM}$ 86, the quarry site, as shown in Table 10.

A closer look at the tertiary flake class also provides evidence that soft hammer activity dominated throughout the site. The two 1 argest categories of platform types in a 11 four site areas were the SMFP and SLPF categories, both of which are characteristic of soft hammer percussion and pressure flaking activities. The percentage of these categories are 1 isted in Table 11. These two categories not on 1 y comprise a significant percentage of the total flakes in these areas, but they also reveal some degree of consistency among the nine areas. This could indicate that not only was soft hammer activity the dominant activity, but it also occurred over a wide portion of the site. Further analyses of other areas in the site could provide more insight into the level of activity that occurred and the disbursement of this activity.

The high percentages of tertiary flakes, in genera 1, and SMFP and SLPF, in particular, undoubtedly reflects the importance of pressure flaking as we 11 as soft hammer percussion at 41 BX 228. Overa 11. it is obvious that hard hammer percussion was never an important activity at 41 BX 228 . It is suspected that primary cobble reduction (hard hammer activity) occurred adjacent to the site within the stream bed 1 ithic resource area. It is clear that throughout the site's occupational history flintknappers were carrying out what Shafer (1976a:9) refers to as Step II and Step III reduction techniques, soft hammer bifacial thinning and pressure flaking final trimming. A11 of the analyzed areas of the site show similar overal1 patterns of $f 1$ ake and platform type ratios. This suggests that similar flintknapping activities were evidenced al1 across the site. Lithic debitage distribution patterns are further discussed in section VIII.

Modified Lithic Debitage ( $A$. Joach im McGraw)

During the 1979 field season 2055 fragments of modified 1 ithic debitage were collected from excavated units. Modified debitage can be defined as the 1 ithic waste products ( $f 1$ akes, chips, and chunks) that show evidence of edge modification. Edge modification includes both purposeful retouch and incidental edge damage. Purposeful retouch is the patterned removal of a series of small flakes along the edge(s) of a piece of debitage. Incidental edge damage can be caused by aboriginal utilization of a piece of debitage as an informal tool or by postdepositional edge breakage such as that created by excavation tools. Al1 modified debitage is composed of medium- to finegrained local chert.

We11 over 90\% of a 11 modified debitage consisted of (usual1y dorsa1) edge- or end-damaged artifacts. This damage was characterized by patterns of sma 11 utilization scars along an edge and has been referred to by some as "nicking"--bifacially occurring random microspal1s on blade 1 ateral edges produced by a drawing or sawing motion (Hester and Shafer 1975:181). Ode11 (1979:329) described further distinctions between wear patterns on edges used transversely (e.g.o scraping) and those used longitudinally (e.gog cutting). 
TABLE 9. FLAKE FREQUENCY COMPARISONS

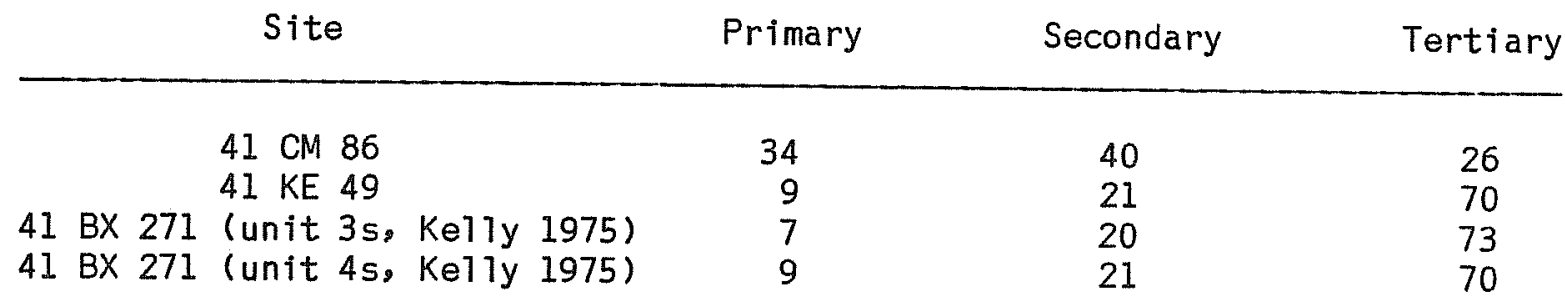

TABLE 10. RATIOS OF PRIMARY, SECONDARY, AND TERTIARY FLAKES

\begin{tabular}{cccc} 
Area & Primary & Secondary & Tertiary \\
\hline D & 1 & 18 & 80 \\
E & 2 & 17 & 81 \\
G & 2 & 20 & 78 \\
H & 2 & 21 & 77 \\
I & 2 & 16 & 82 \\
J & 1 & 14 & 85 \\
E1005 N929 & 1 & 27 & 72 \\
E1010 N940 & 1 & 16 & 83 \\
& 3 & 18 & 79
\end{tabular}

TABLE 11. PERCENTAGE OF SMALL MULTIFACET PLATFORM AND THE SMALL LIPPED PLATFORM FLAKE CATEGORIES (PER UNIT)

$\begin{array}{ccc}\text { Area } & \begin{array}{c}\text { Percentage of } \\ \text { SMFP }\end{array} & \begin{array}{c}\text { Percentage of } \\ \text { SLPF }\end{array} \\ \text { D } & 45 & 18 \\ \text { E } & 45 & 18 \\ \text { F } & 41 & 22 \\ \text { G } & 43 & 17 \\ \text { H } & 42 & 20 \\ \text { I } & 38 & 22 \\ \text { J } & 40 & 16 \\ \text { El005 N929 } & 46 & 14 \\ \text { E1010 N940 } & 40 & 18\end{array}$


The wear patterns present on thicker pieces of chipped stone may be associated with the transverse motion. while thinner fragments with less deeply etched scars may be related to longitudinal action. Very little modified debitage from $41 \mathrm{BX} 228$ was actual1y purposefully retouched.

Modified debitage at 41 BX 228 primarily represents discarded informal flake tools. Most edge damage is believed to have resulted from short term use as cutting or scraping tools. The specific types of cutting and scraping functions (i.e., hard or soft wood, butchering, hide processing, plant processing) cannot be determined without detailed wear pattern studies. It is assumed that informal flake tools were discarded in or near the location that they were used. Therefore, the distributional patterns of modified debitage may reflect the location of activity areas within the site. The highest frequencies of modified debitage were collected from Areas $I, A$, $H$, $C$, and $B$, respectively. The distribution of modified debitage from these areas is discussed in greater detail in section VIII.

\section{Ihick Bifaces (TK)}

Thick bifaces are defined as percussion-flaked bifaces with a maximum thickness of $1.5 \mathrm{~cm}$ or more and a flaking pattern which suggests form shaping rather than flake production (bifacial cores). The distinction between thick bifaces and bifacial cores, as previously mentioned, is somewhat subjective; thus, some of the thick bifaces may have al so functioned as cores. Thick bifaces are primarily fashioned by hard hammer and soft hammer percussion techniques. Marginal trimming is absent from most specimens. The majority of the thick bifaces appear to be rejected products of the early stages of bifacial tool production. Most were obviously discarded due to breakage, high thickness to size ratio, and/or inherent material flaws.

Thick bifaces frequently retain patches of cortex on one or both faces. Central ridges or knots, usual $1 y$ accompanied by hinge or step fractures, are often present. Artifact edges are most often sinuous to very sinuous. Those thick bifaces with slightly sinuous to straight edges are general 1 y those with marginal trimming resembling thin bifaces. It is probable that some of these were used as tools; however, use cannot be assessed without detailed wear pattern studies.

The thick bifaces have been divided into the following 15 groups based largely on morphological characteristics:

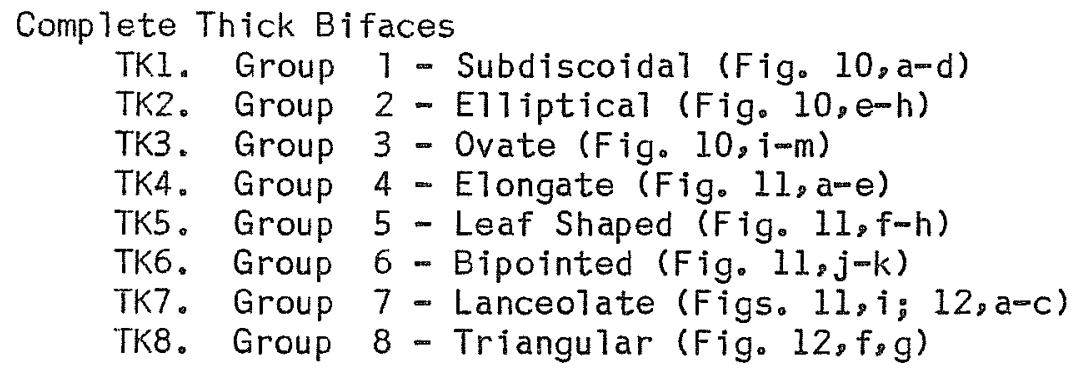




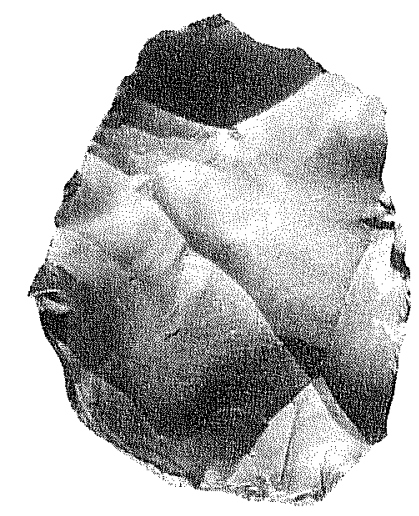

a

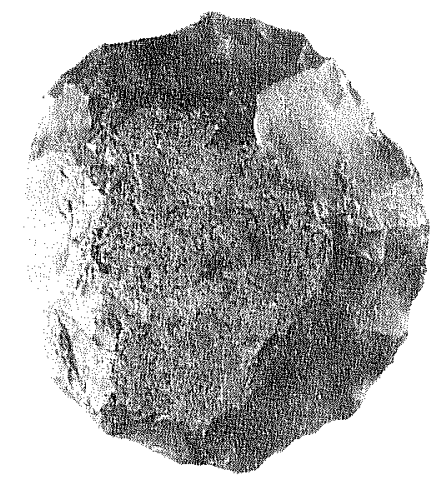

b

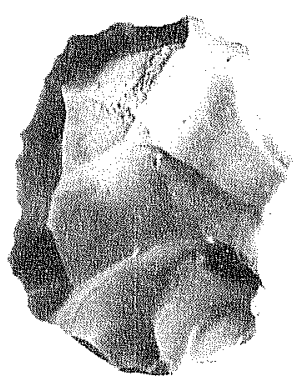

c

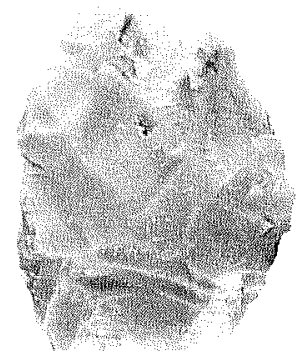

d
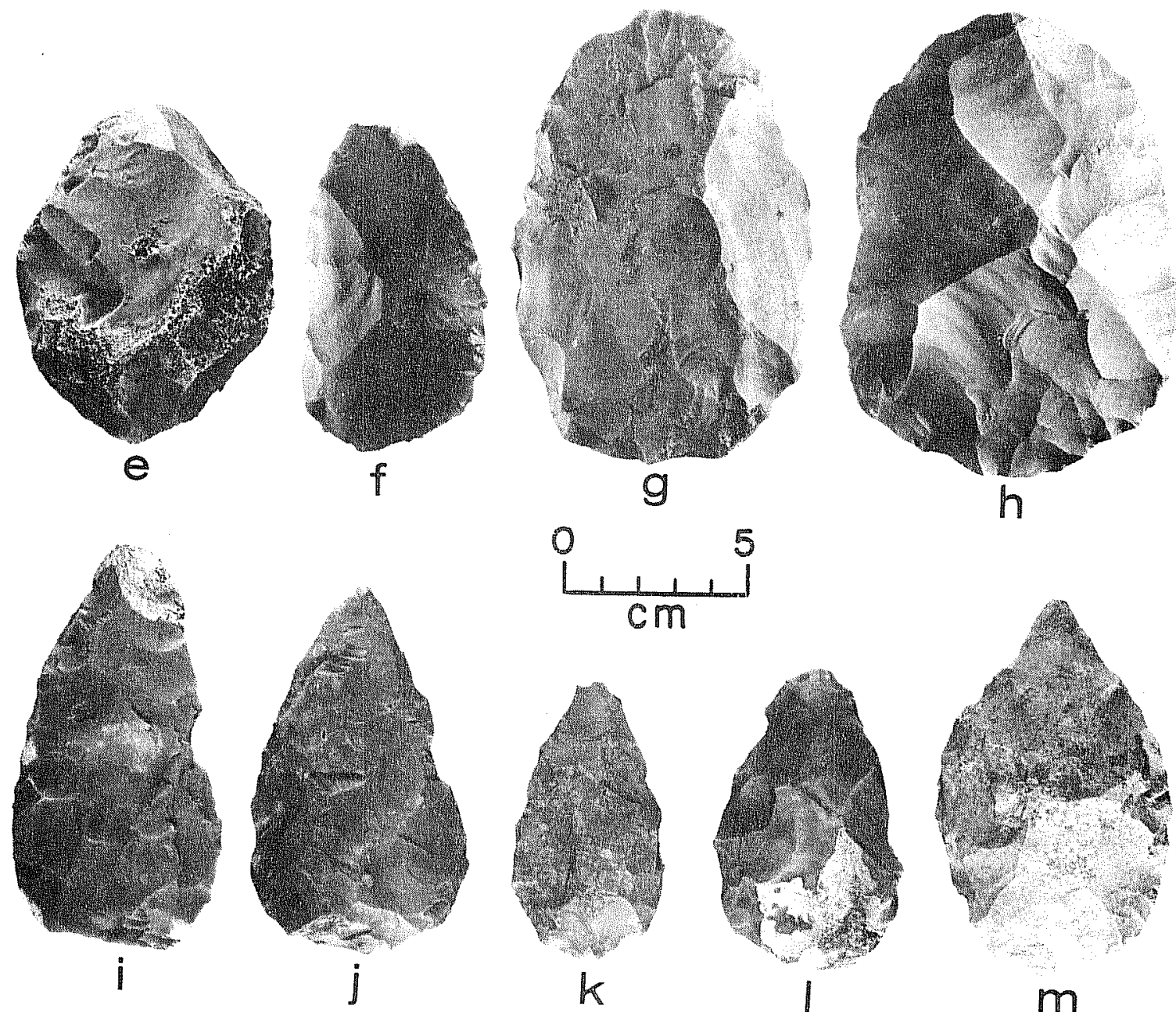

h
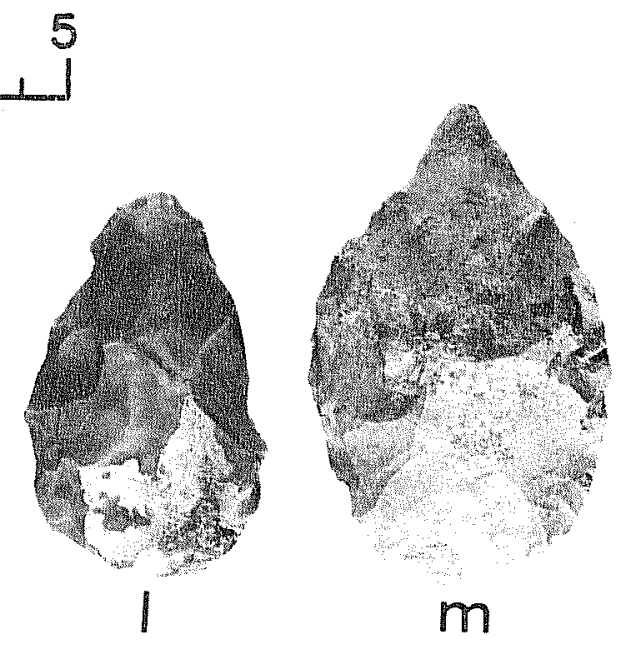

Figure 10. Thick Bifaces, Groups $1-3$. a-d, TKI; e,f, TK2:I; g, h, TK2:2; im, TK3. Lot numbers: a, 153; b, I64; c, 212; d, A-5; e, 195; f, 438; $g=394 ; h, 391 ; i, 184 ; j, 191 ; k, 222 ; i, 79 ; m, 321$. 


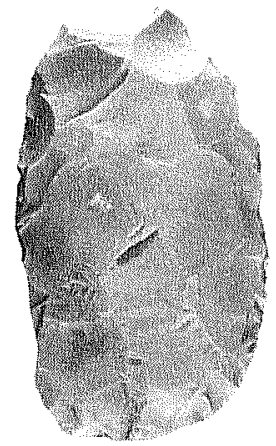

a
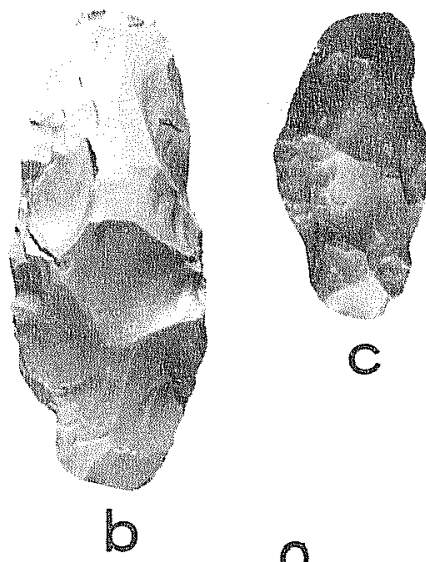

c

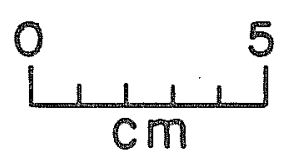

5
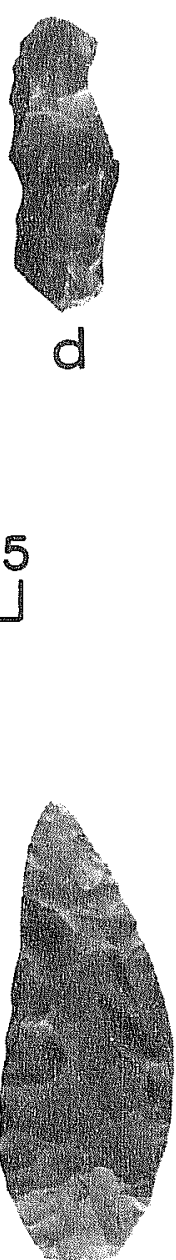

9

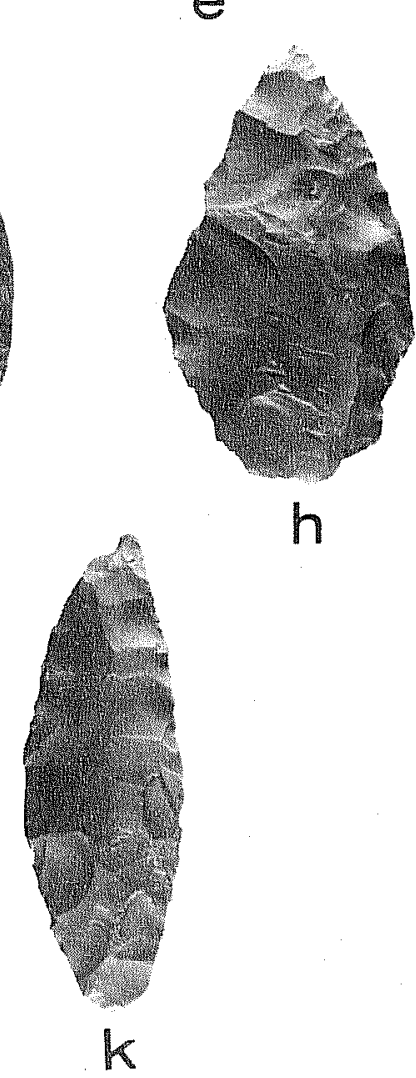

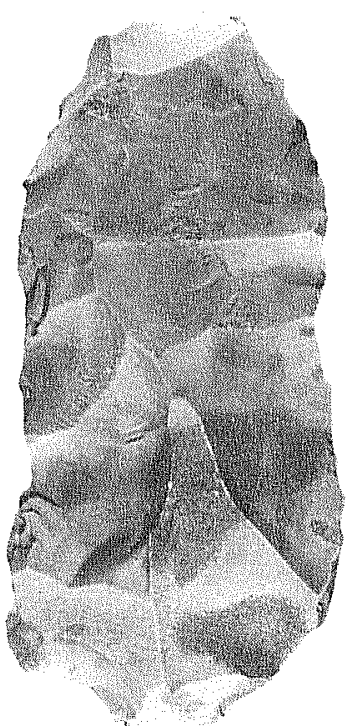

e
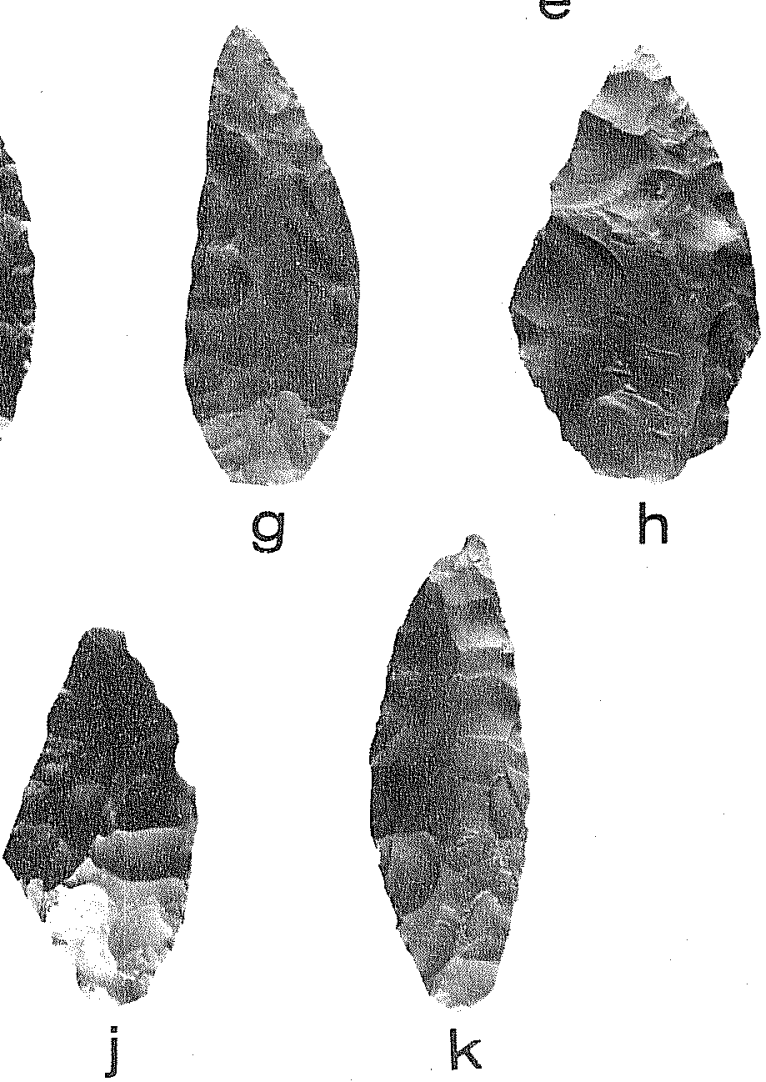

Figure 11. Thick Bifaces, Groups 4-7. a,b,e, TK4:2; c,d, TK4:1; f-h, TK5; $i$, TK7; j,k. TK6. Lot numbers: a, 386; b, 231; c, 261; d, 445; e, 395; $f, 277 ; g, 397 ; h, 246 ; i, 391 ; j, 394 ; k, 226$. 


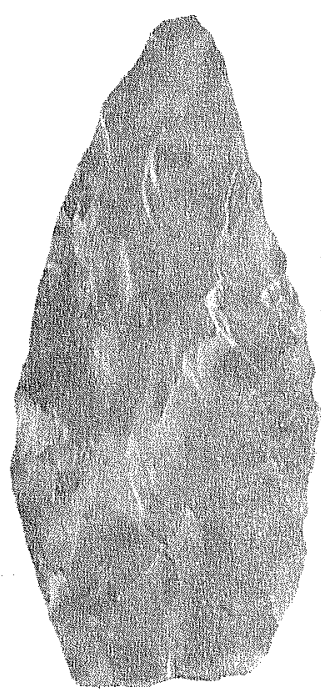

a
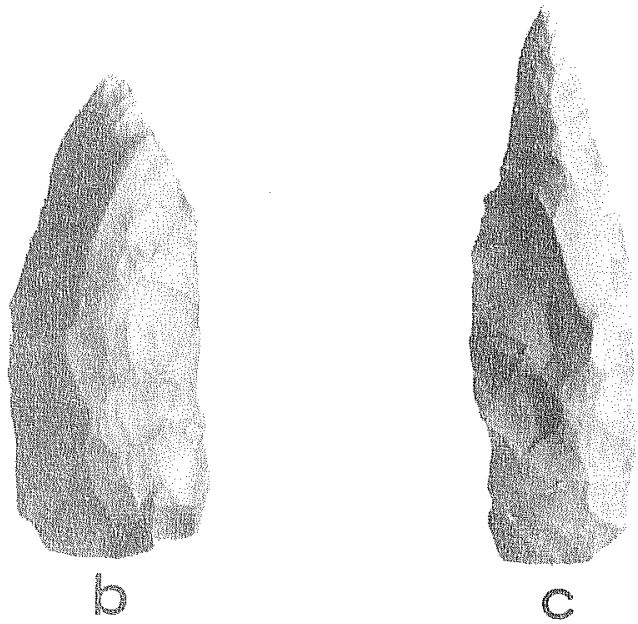
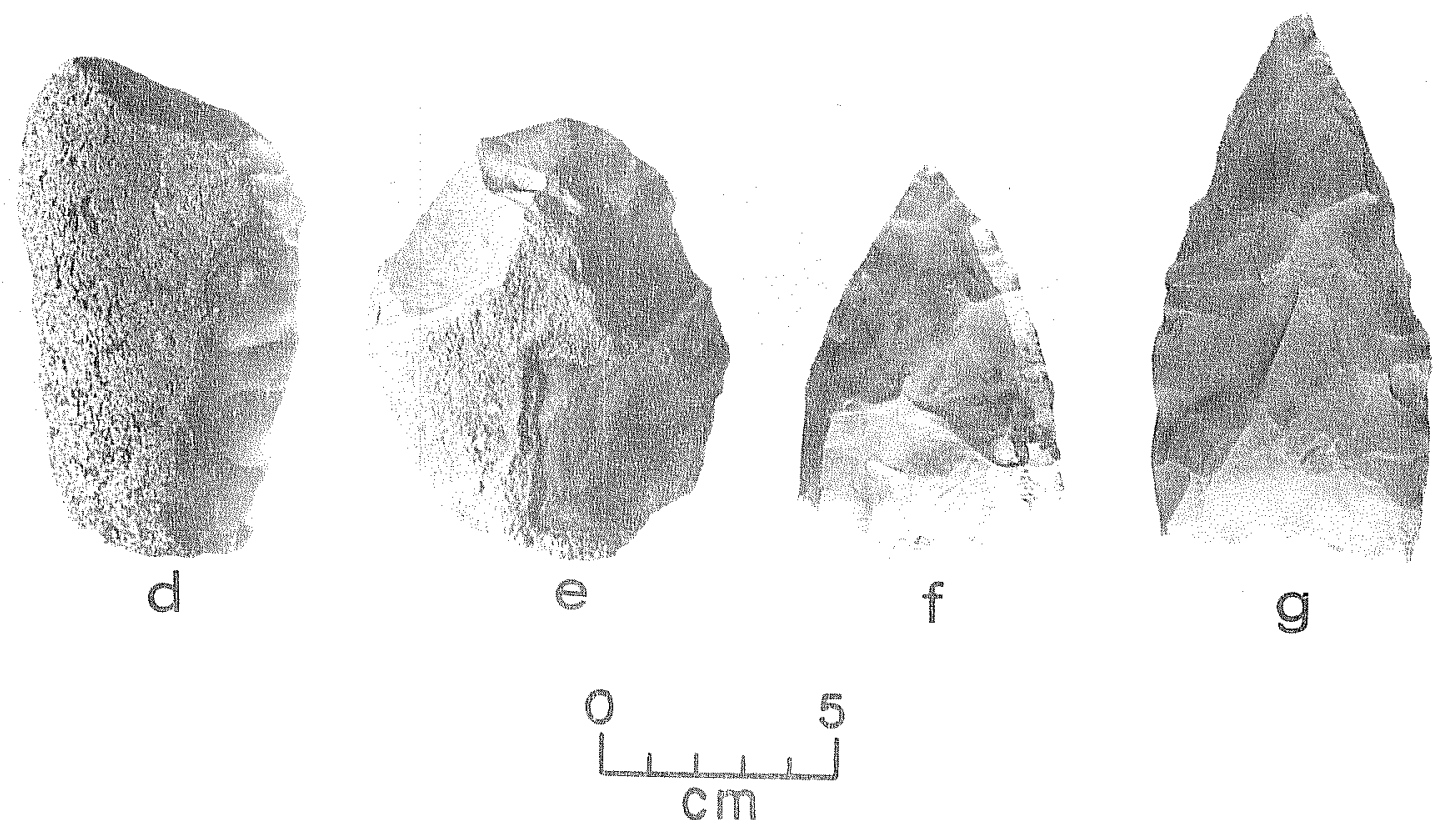

Figure 12. Thick Bifaces. Groups 7o9. am C, TK7: d,e, TK9; fog. TK8. Lot numbers: a, $387:$ b. $467:$ c. $391 ; d, 395 ;$ e, $231 ; f, 97 ; \mathrm{g}, 128$. 
TK9. Group 9 - Cortex-Proximal (Fig. 12,d,e)

TK10. Group 10 - Irregular (not illustrated)

Incomplete Thick Bifaces

TK11. Group 11 - Rounded Fragments (not illustrated)

TK12. Group 12 - Triangular Fragments (not illustrated)

TK13. Group 13 - Narrow Fragments (not illustrated)

TK14. Group 14 - Pointed Fragments (not illustrated)

TK15. Group 15 - Miscellaneous (not illustrated)

\section{Complete Thick Bifaces}

IKle Group 1 - Subdiscoidal (27 specimens)

Group 1 thick bifaces have a generally rounded appearance with discoidal to suboval to subtriangular outlines, and the width is greater than threequarters of the length. These bifaces are relatively small unfinished artifacts seemingly rejected due to high thickness to size ratio. Flaking appears to be hard hammer. with 1 ittle or no marginal trimming. Cortex patches remain on 21 specimens (78\%). Edges are sinuous.

IK2. Group 2 - Elliptical (25 specimens)

Group 2 thick bifaces have an elliptical to oval to subrectangular outline, and the width is less than three-quarters of the length. Proximal and distal ends are generally indistinguishable. Cortex patches remain on 18 specimens (72\%). Edges are slightly to markedly sinuous.

TK2:1. Form 1 - Narrow (width $<7.0 \mathrm{~cm}: 19$ specimens)

Group 2. Form 1 thick bifaces appear to be unsuitable for further thinning due to extreme thickness, flaws, hinge fractures, etc.

TK2:2. Form 2 - Broad (width $>7.0 \mathrm{~cm}$; 6 specimens)

Group 2, Form 2 thick bifaces are larger and broader than those of Group 2 , Form 1. Several appear to be unused blanks, as there are no apparent obstacles to further trimming, while others appear to be failed blanks used as tools or purposefully designed tools.

IK3. Group 3 - Ovate (45 specimens)

Group 3 thick bifaces are pointed ovate to cordiform in out 1 ine. They have a distinctly pointed distal end and a we17-rounded, generally broad proximal end. This group is the most numerous thick biface group. Most of the specimens have been carefully shaped and have regular edges which are straight to only sightly sinuous. Most appear discarded due to 
technological obstacles. Cortex patches remain on 21 specimens (47\%). A few specimens have marginal trimming and may have been used as tools.

\section{TK4. Group 4 - Elongate (14 specimens)}

Group 4 thick bifaces are elliptical in out 1 ine shape and appear relatively long and thick. Width is less than one-half of the length, and thickness is greater than one-half of the width. Proximal and dista 1 ends are usual $1 y$ indistinguishable, both being either rounded or slightly pointed. Cortex patches remain on five specimens (36\%). Edges are slightly sinuous to straight. Hinge fractures are usually present on one or both faces, making further thinning very difficult. Size, shape, and thickness of Group 4 Form 2 thick bifaces strongly suggest that many of these artifacts represent unfinished distally beveled tools-either bifacial Clear Fork or Guadalupe tools. Group 4 is divided into two forms based on a distinct size differentiation.

TK4:1. Form 1 - Smal1 Elongate (4 specimens)

Group 4, Form 1 thick bifaces have a length of less than $7 \mathrm{~cm}$.

TK4:2. Form 2 - Large Elongate (10 specimens)

Group 4. Form 2 thick bifaces are greater than $9 \mathrm{~cm}$ in length. Seven specimens retain cortex patches: on four of these the cortex forms a $f l a t$ facet on one end and suggests a cortex flake platform, thus, distinguishing them from bifacial cores.

IK5. Group 5 - Leaf Shaped (11 specimens)

Group 5 thick bifaces are narrow and leaf shaped distal ends are distinctly pointed and proximal ends well rounded. This is one of the better-finished thick biface groups; all specimens exhibit some degree of marginal trimming. Group 5 thick bifaces bear some resemblance to Group 3 thick bifaces in terms of general shape but are smaller, narrower, and better thinned. Sma 11 cortex patches remain on four specimens (36\%). Edges are straight to slightly sinuous. Most of the Group 5 thick bifaces have a thick knot or ridge; otherwise, they resemble thin bifaces. It appears very 1 ikely that these bifaces were used as tools, perhaps for performing cutting tasks.

TK6. Group 6 - Bipointed (4 specimens)

Group 6 thick bifaces are 1 anceolate to a narrow diamond shape in out 1 ine; both ends are distinctly pointed. Cortex patches remain on two specimens $(50 \%)$, both of which appear to be discarded because of inherent flaws. One specimen is well trimmed and may be a finished tool. Group 6 thick bifaces are similar to Group 5 thick bifaces in terms of size and workmanship. 
IK7. Group 7 - Lanceolate (4 specimens)

Group 7 thick bifaces have a 7 anceolate outline with straight to slight ly convex bases and subparallel converging blade edges. Cortex remains on one specimen (25\%). Edges are straight to slightly sinuous. Artifacts from Group 7 vary considerably in size. One specimen ( $F$ ig. Il,i) with large billet flake scars on both faces is the largest biface recovered from 41 BX 228. Most of the Group 7 thick bifaces are marginally trimmed, suggesting that these may be finished tools similar to Group 5 thick bifaces.

TK8. Group 8 - Iriangular ( 6 specimens)

Group 8 thick bifaces have triangular to subtriangular outlines. Bases are straight on two specimens, slightly convex on another, and slightly concave on three. Cortex patches remain on four specimens (67\%). Edges are 57 ightly sinuous. Marginal trimming is present only on one specimen.

IK2. Group 9-Cortex-Proximal (4 specimens)

Group 9 thick bifaces are relatively small hard hammer percussion-chipped artifacts with a cortex-covered side or end opposite a bifacially worked edge. The cortex-covered surface gives the artifact a "backed" appearance. Weir (1976a:65) discusses similar artifacts which he calls "thick-bladeproximal-cortex bifaces." They have also been described under the functional rubric "choppers." The bifacially worked edges opposite the cortex edges exhibit marginal retouch, crushing, and dulling, apparentiy the result of heavy usage.

\section{IK10. Group 10 - Irregular (17 specimens)}

Group 10 thick bifaces are al 1 complete or nearly complete with irregular outlines not conforming to any of the above groups. Many are asymmetrical. Cortex occurs on 12 specimens $(71 \%)$. The group is divided into two forms based on the degree of completion.

TK10:1. Form 1 - Crude (11 specimens)

Group 10, Formi 1 thick bifaces are percussion chipped. Ten specimens retain smal1 to 7 arge patches of cortex. Edges are sinuous. Marginal trimming is absent. Group 10, Form I specimens appear to be unused bifacial failures.

\section{TK10:2. Form 2 - Marginally Trimmed (6 specimens)}

Group 10, Form 2 thick bifaces have marginal trimming and straight to slight?y sinuous edges. Outlines are asymmetrical. These bifaces were probably functional too 15. One specimen with two incipient basal notches probably represents an unfinished dart point. 


\section{Incomplete Thick Bifaces}

Groups 11-15 include various categories of thick biface fragments. Most, if not all, are manufacturing failures broken along flaw 1 ines by hinge fractures or by end shock (C'rabtree 1972:60).

IK11. Group 11 - Rounded Fragments (19 specimens)

Group 11 thick biface fragments appear to be basal portions of Group 3 thick bifaces or end fragments of Group 2 thick bifaces. Cortex remains on 10 specimens (53\%).

IK12. Group 12 - Iriangular Fragments (4 specimens)

Group 12 thick bifaces appear to be basal fragments of Group 8 thick bifaces; a 11 cortex has been removed.

IK13. Group 13 - Narrow Fragments (8 specimens)

Group 13 thick biface fragments have convex bases and subparallel to convex blade edges. Most appear to be fragments of Group 5 or Group 7 thick bifaces; however, these fragments are not as well thinned or trimmed, possibly because they were broken during this process.

TK14. Group 14 - Pointed Fragments (20 specimens)

Group 14 thick bifaces are fragments which appear to be distal tips from various thick biface groups.

IK15. Group 15 - Miscellaneous (42 specimens)

Group 15 thick bifaces include various lateral, medial, and unclassifiable thick biface fragments.

\section{Ihin Bifaces (TN)}

The thin biface category includes al 1 bifacial artifacts 1 ess than $1.5 \mathrm{~cm}$ thick except those forms commonly referred to in the 1 iterature as projectile points or perforators. For comparative purposes, these are discussed separately.

Thin bifaces represent the 1 ater stages of bifacial tool production, including what Skelton (1977:149-150) calls Stages 5 (preforms) and 6 (finished tools). Thin bifaces usually exhibit wide, shallow, 1 inear flake scars extending over half the width of the blade (soft hammer or billet flakes) and small narrow flakes along the blade margins (pressure flakes). 
Without a detailed wear pattern study it is often difficult if not impossible to determine which thin bifaces were used as tools and which were never finished. Technologically oriented analyses such as Skelton's (1977) or Skinner's (1971) use the presence of marginal pressure flaking as an indication that the biface is a finished tool. However, artifacts that are often referred to as unfinished or rejected bifaces may have been used despite the absence of marginal pressure flaking.

The thin bifaces are divided into two general divisions: complete and fragmentary. The complete categories also include nearly complete specimens which left 1 ittle doubt as to complete shape. Fragmentary bifaces were grouped separately due to the difficulty of accurately reconstructing missing portions. Complete or nearly complete bifaces are described in eight groups based on general out 1 ine shape and (in some cases) size. These groups are further divided into forms based on degree of finish, size, subtle morphological differences, basal modification, etc. Thin biface fragments are also divided into eight groups based on similar attributes. This system relies heavily on subjective examination; however, the use of the following group and form definitions should allow replication by other researchers:

Complete Thin Bifaces

TNI. Group 1 - Lanceolate

TNI:1. Form 1 - Percussion Flaked (Fig. 13,a)

TN1:2. Form 2 - Pressure Flaked (Fig. 13,b-d)

TN2. Group 2 - Narrow

TN2:1. Form 1 - Bipointed (Fig. 13,h,i)

TN2:2. Form 2 - Leaf (Fig. 13,e-g)

TN3. Group 3 - Leaf to Ovate

TN3:1. Form 1 - Smal1 (Fig. $13, j-1$ )

TN3:2. Form 2 - Medium (Fig. 13,0,p)

TNB :3. Form 3 - Large (Fig. $13, m, n$ )

TN3:4. Form 4 - Asymmetrical (Fig. 13, q)

TN4. Group 4 - Rounded

TN4:1. Form I - Discoidal (Fig. 14,a,b)

TN4:2. Form 2 - Elliptical (Fig. 14, c,d)

TN5. Group 5 - Subtriangular

TN5:1. Form 1 - Narrow (Fig. 14,e,f)

TN5:2. Form 2 - Broad (Fig. $14, g, h)$

TN6. Group 6 - Triangular

TN6:1. Form 1 - Concave Base (Fig. $14, i, j$ )

TN6:2. Form 2 - Straight Base (Fig. 14,k-0)

TN7. Group 7 - Smal1 Triangular

TN7:1. Form 1 - Triangular (Fig. 14,p-s)

TN7:2. Form 2 - Subtriangular (Fig. $14, t-w)$

TN8. Group 8 - Stemmed

TN8:1. Form 1 - Triangu 1 ar B1ade--Contracting Stem (Fig. $15, a-e)$

TN8:2. Form 2 - Miscellaneous Contracting Stem (Fig. 15,f-h)

TN8:3. Form 3 - Expanding Stem (Fig. 15, $i, j$ ) 


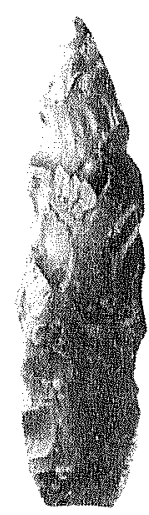

a

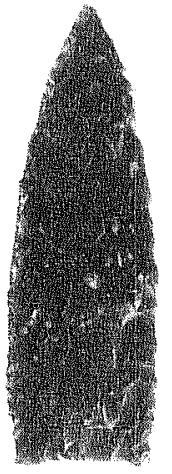

b

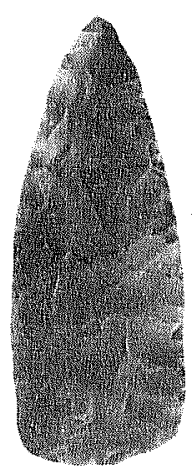

c

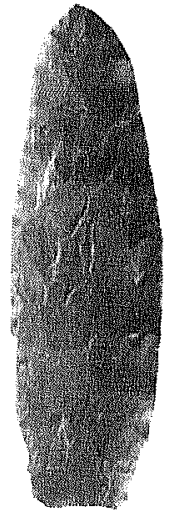

d

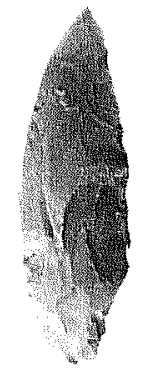

e

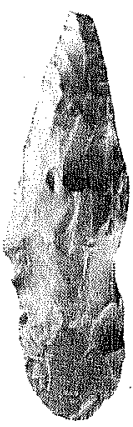

$f$

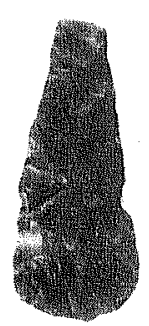

9

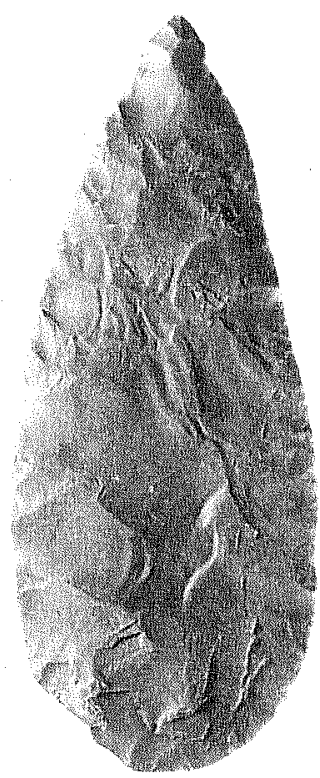

$\mathrm{m}$

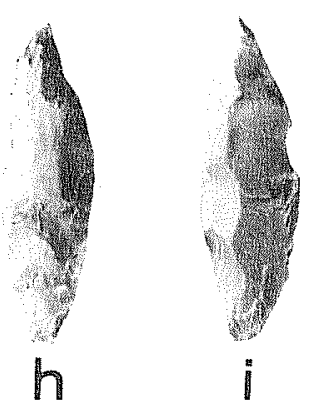

h
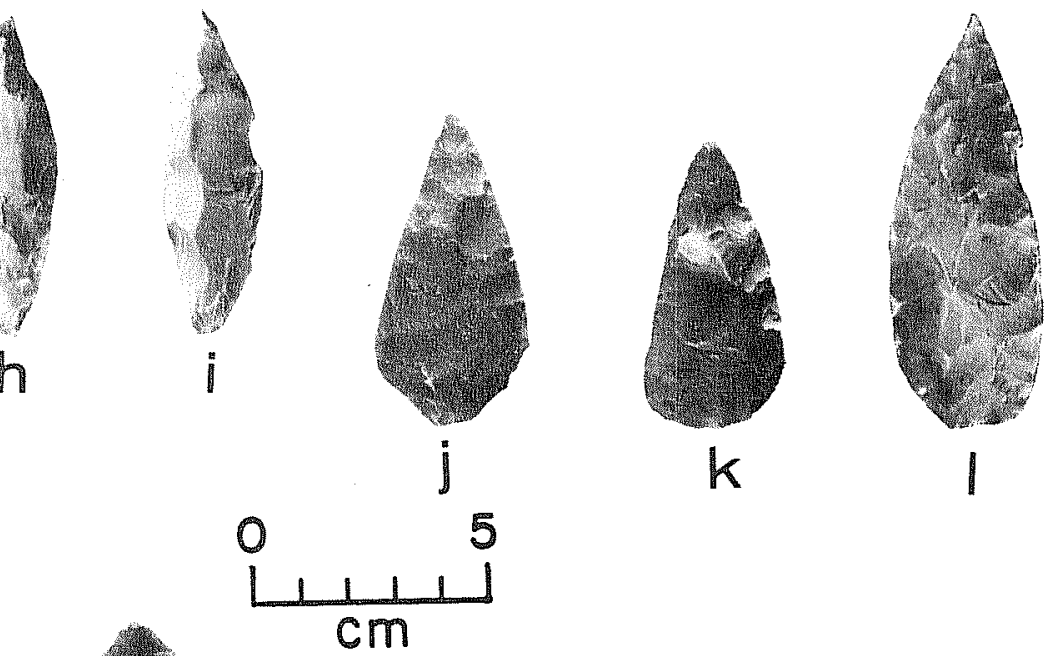

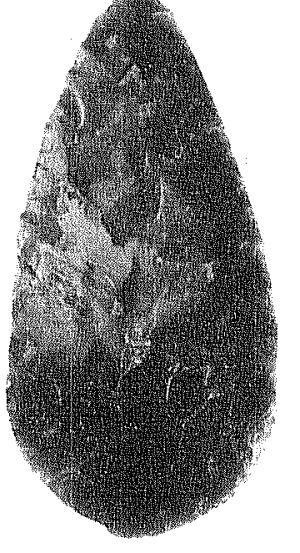

n

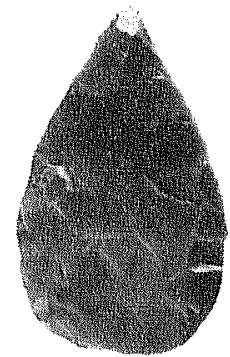

0
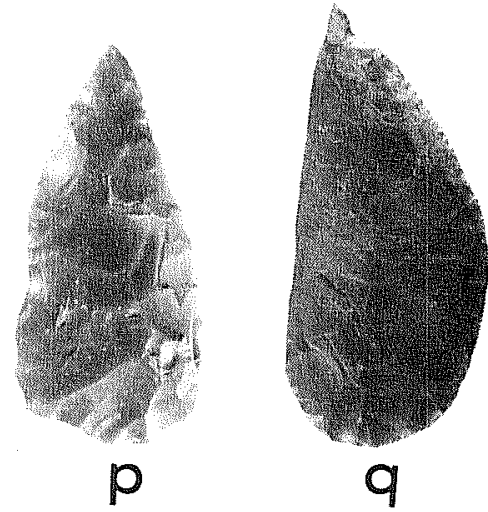

Figure 13. Thin Bifaces, Groups 1-3. a, TNI:1;b-d, TN1:2; e-g, TN2:2; $h, i$, TN2:1; j-1. TN3:1; m. $n$. TN3:3; $0, p$, TN3:3; q. TN3:4. Lot numbers: a, 465; b, 281; c, 395; d, 397; e, 24; f, 172; g, 146; h, 395; i, I-3; j, 389; k, $130 ; 1,324 ; m, 181, n, 138 ; 0,350-156 ; p, 394 ; q, C-7$. 


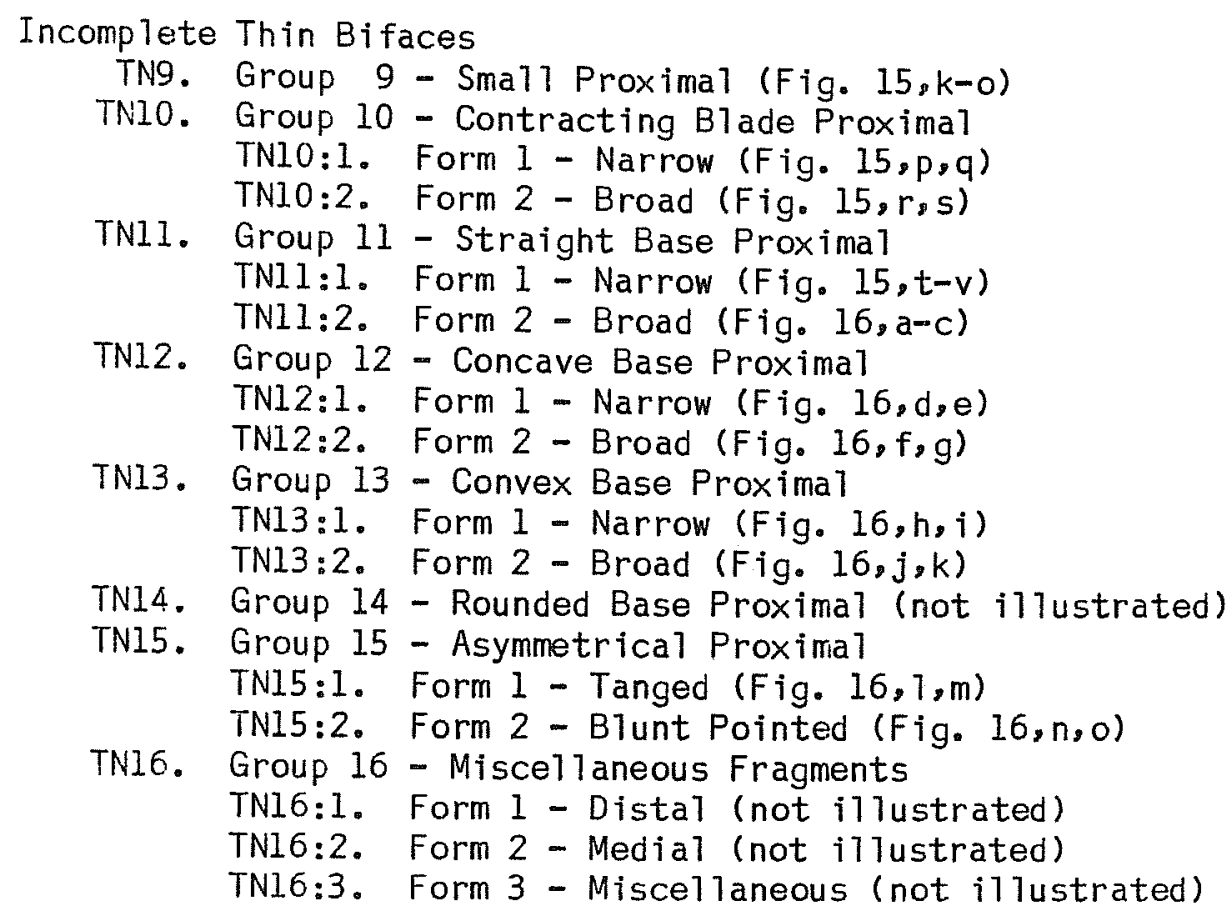

\section{Complete Thin Bifaces}

INI. Group 1 - Lanceolate (12 specimens)

Group 1 thin bifaces have 1 anceolate blade out 1 ines, and blade edges are paral1el to 51 ight 7 y convex. Bases are straight to slightly concave or convex. As a group, these bifaces have a relatively long and narrow appearance (width <1/2 length). Group 1 is divided into two forms based on flaking.

TN1:1. Form 1 - Percussion Flaked (3 specimens)

Group 1, Form 1 thin bifaces are percussion flaked with 1 ittle or no marginal pressure flaking. The edges are sinuous, and they appear unfinished. Hinge fractures probably prevented final thinning.

TN1:2. Form 2 - Pressure Flaked (9 specimens)

Group I, Form 2 thin bifaces are very well finished. Flake ridges from probable billet flaking have been removed, and edges are very straight. Parallel transverse flaking is present on several specimens. Several specimens also have a very glossy sheen and darkened to reddened colors, strongly suggesting heat treatment. Form 2 bifaces appear to be finished artifacts well suited for use as knives and possibly as projectile points. Minute unifacial retouch occurring along one or both edges is present on several specimens. 


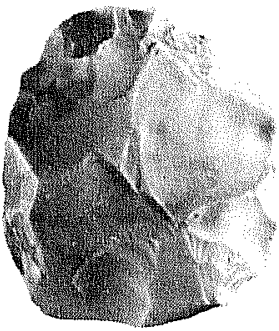

a

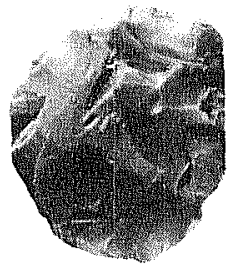

b

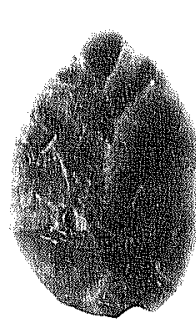

c

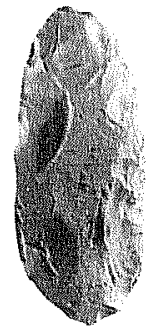

d

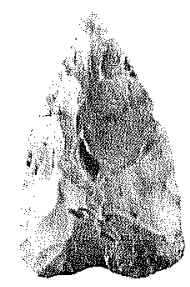

e

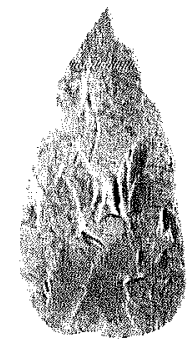

f
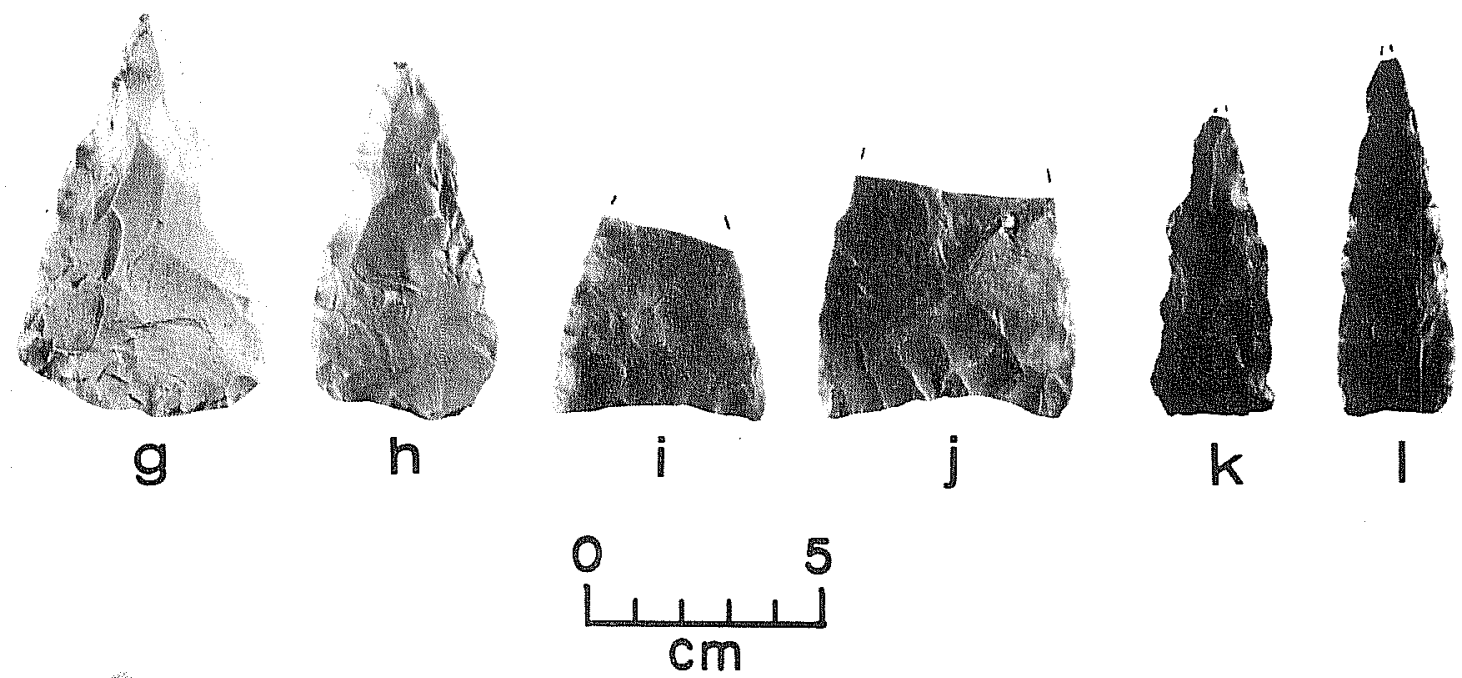

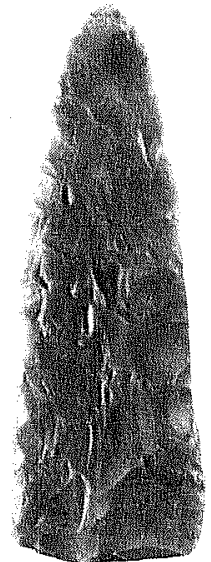

$\mathrm{m}$

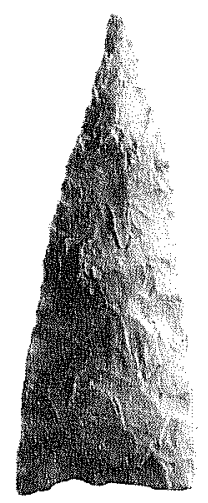

$n$

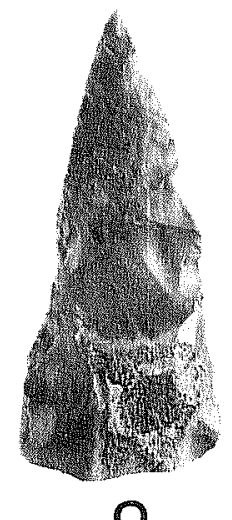

0
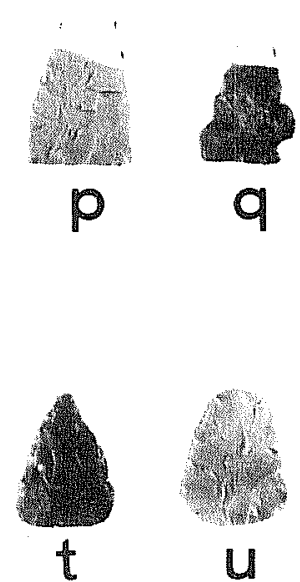

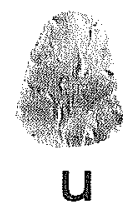

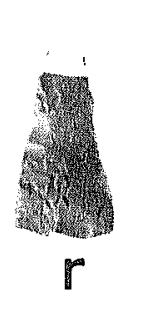

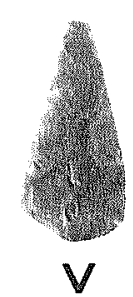

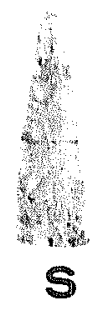

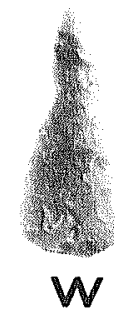

Figure 14. Thin Bifaces, Groups 4-7. $a, b$, TN4:1; c, d, TN4:2; e,f, TN5:1; $g, h$, TN5:2; $i, j$, TN6:l; k-0, TN6:2; $-5-5$, TN7:l; t-w, TN7:2. Lot numbers: a, 396; b, $F-3 ; c, 395 ; d, 265 ;$ e, 138; f, E-5; g, 116; h, 465; i, 46; $j, 395 ; k, 330 ; 1,397 ; m, 394 ; n, 187 ; 0,142 ; p, A-3 ; q, 43 ; r, F-1 ; s, 63$; t, 389; u, 456; v, 311; w, 52. 


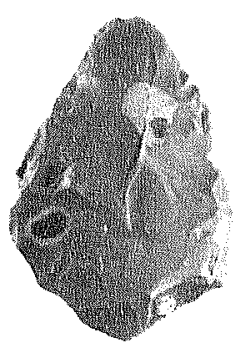

a

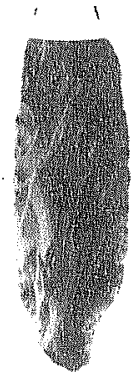

$f$
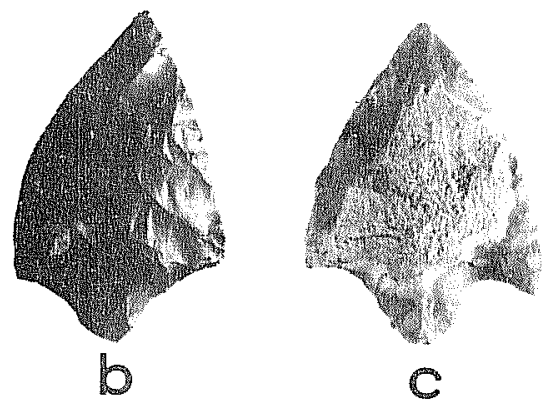

C
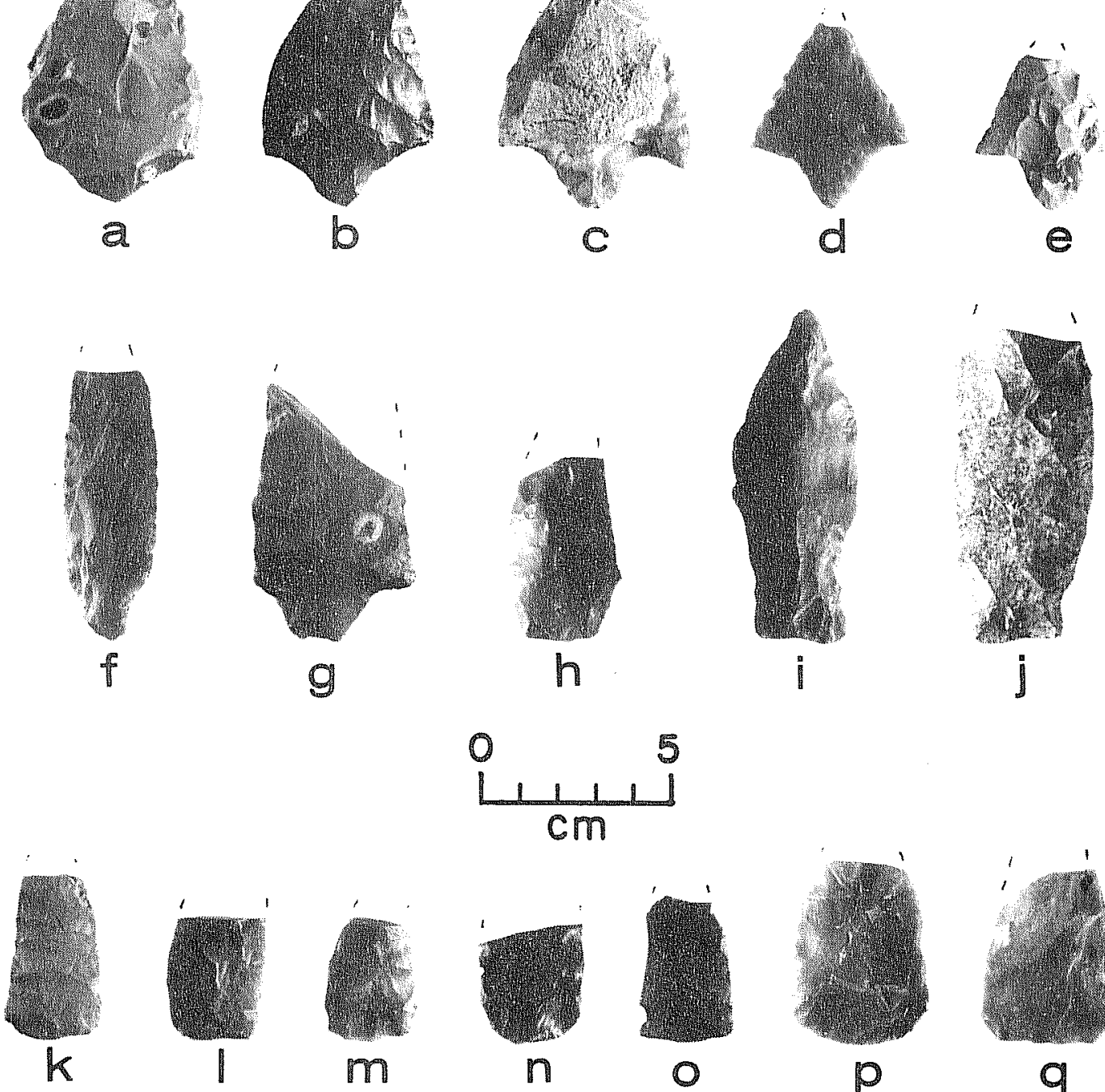

0
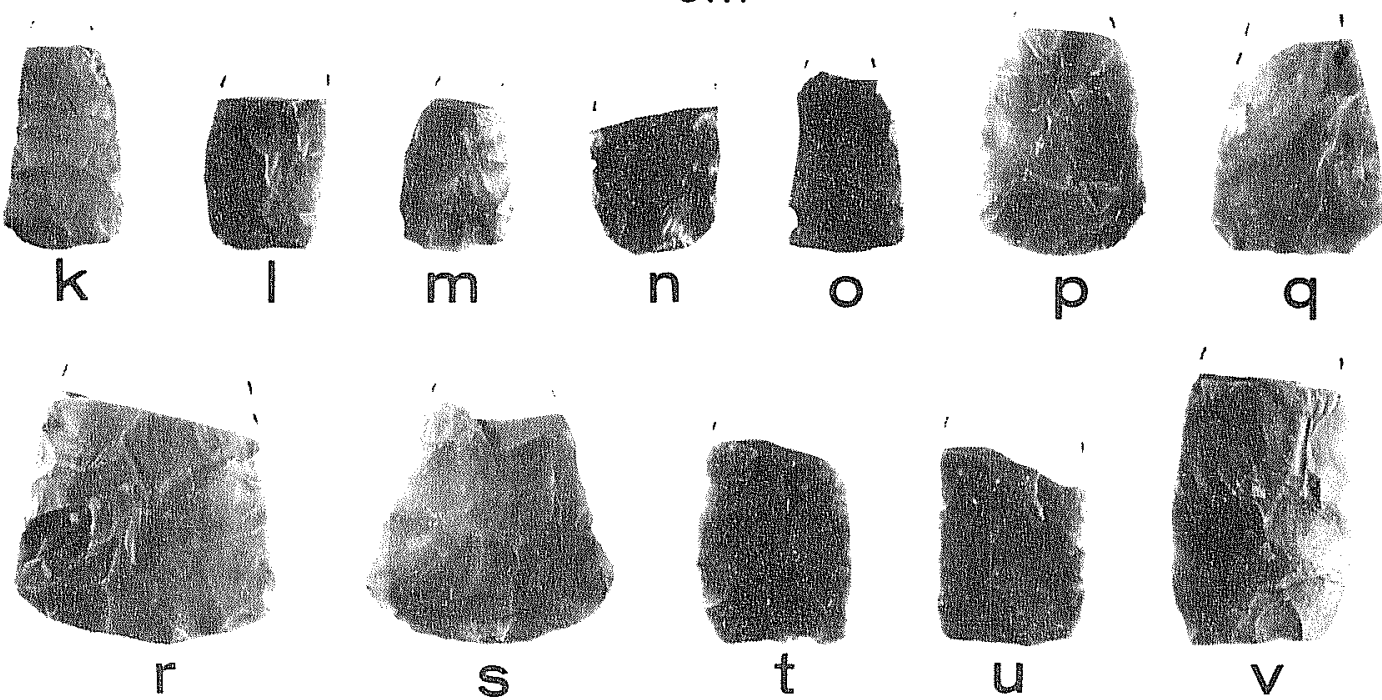

Figure 15. Thin Bifaces, Groups 8-11, a-e, TN8:1; f-h, TN8:2; $i, j$, TN8:3; $k-0$, TN9; $p, q$, TN10:1; $r, s$, TN10:2; t-v, TN11:1. Lot numbers: a, 393; b, 187; c, 211; d, 115; e, 395; f, B-2; g, 149; h, 260; $i, 179 ; j, 387$; $k, 399 ; 1,32 ; m, 92 ; n, 95 ; 0,52 ; p, E-4 ; q, 85 ; r, 241 ; s, 120 ; t, 299$; $u, 465 ; v, 260$. 
One specimen (Fig. 13,b) has a lanceolate outline and slightly concave base. Blade edges are serrated, and the artifact is very glossy, probably heat treated. Flaking is collateral billet flaking obscured by parallel transverse pressure flaking. Slight basal thinning is present.

IN2. Group 2 - Narrow (9 specimens)

Group 2 thin bifaces have bipointed (Form 1) and leaf (Form 2) outline shapes; both forms appear very narrow and relatively thick. Thickness is usually less than one-half the width. Maximum width occurs near the midpoint of most specimens. Flaking is apparently the result of percussion and pressure techniques. Group 2 thin bifaces may have functioned as cutting, piercing, or reaming tools.

TN2:1. Form 1 - Bipointed (3 specimens)

Group 2, Form 1 thin bifaces are roughly lens shaped, and one end is usually less pointed.

TN2:2. Form 2 - Leaf (6 specimens)

Group 2, Form 2 thin biface specimens exhibit a leaf-shaped out 1 ine with we1 1-rounded bases and narrow, wel1-pointed tips; blade edges are convex.

IN3. Group 3. - Leaf to Ovate (47 specimens)

The outline shape of Group 3 thin bifaces varies from leaf shaped to ovate, with some specimens approaching subtriangular. Generally, this group contains bifaces with a convex base and a distinctly pointed tip. Flaking techniques used include hard hammer (rare), soft hammer (most specimens), and pressure flaking (many). Edges are slightly sinuous to very straight. Most appear to be preforms for various dart points. Some specimens are particularly thin and well worked and may be finished knives.

TNB:1. Form 1 - Small (maximum width $<3.5 \mathrm{~cm} ; 20$ specimens)

TN3:2. Form 2 - Medium (maximum width $-3.5-4.5 \mathrm{~cm}$; 16 specimens)

TN3:3. Form 3 - Large (maximum width $>4.5 \mathrm{~cm} ; 9$ specimens)

TN3:4. Form 4 - Asymmetrical (2 specimens)

Group 3, Form 4 thin bifaces have asymmetrical out 1 ines that are somewhat leaf shaped. One specimen (Fig. $13, q$ ) is an extremely we 11-worked biface. 
The distal tip is unifacially notched. The straight lateral edge has minute unifacial retouch, while the opposite convex side has bifacial retouch.

IN4. Group 4 - Rounded (17 specimens)

Group 4 thin bifaces have a general1y "rounded" appearance. Outlines range from discoidal (Form 1) to elliptical or oval (Form 2). Most specimens appear to be flake bifaces, often having only marginal trimming on the proximal surfaces. Flaking techniques employed are hard and soft hammer percussion and pressure flaking. Function is unknown; perhaps some were preforms, and others may have been used for cutting and scraping.

TN4:1. Form 1 - Discoidal (width $>3 / 4$ length; 7 specimens)

TN4:2. Form 2 - E1Tiptical (width <3/4 Tength; 10 specimens)

IN5. Group 5 - Subtriangular (24 specimens)

Group 5 thin bifaces have subtriangular outlines; some specimens are slightly asymmetrical. Blade edges are convex to almost straight. Bases are convex with rounded corners. Flaking varies from percussion to pressure. Size, thinness, and workmanship vary considerably. Many specimens appear heat treated. Function probably includes dart point preforms and finished bifaces possibly used as knives. Two forms were arbitrarily defined based on maximum width.

TN5:1. Form I - Narrow (width $<4.0 \mathrm{~cm}$; 11 specimens)

TN5:2. Form 2 - Broad (width $>4.0 \mathrm{~cm}$; 13 specimens)

IN6. Group 6-Triangular (28 specimens)

Group 6 thin bifaces have triangular outlines. As a group they are generally we 71 thinned and carefully worked by soft hammer percussion and sometimes by pressure flaking. Blade edges are generally very regular. Group 6 specimens appear "finished" overal 1 and may have functioned as knives for cutting purposes rather than preforms. Some specimens resemble those in dart point Group 6, Form 3 (D:3)--the "thinned-base early triangular" form which may have functioned as a knife. 
IN6:1. Form 1 - Concave Base ( 6 specimens)

Blade edges in Group 6, Form 1 thin bifaces are straight to sightiy convex or concave. Five specimens are basal fragments that leave 1 ittle doubt as to their complete shape. Bases are comparatively wide with shallow concavities.

\section{IN6:2. Form 2 - Straight Base (22 specimens)}

The majority of Group 6, Form 2 thin bifaces have narrow triangular out 1 ines (base width is usually one-third to one-half the length). B ade edges are straight to slightly convex or concave on reworked specimens. Bases are straight to slightly convex or concave. Several specimens (Fig. 14,k, 1 ) exhibit what appears to be irregular flaking along the blade edges, leaving a denticulated appearance. This pattern is usually associated with a change in edge angle and may be from use-wear or edge damage. Most specimens show evidence of blade reworking or resharpening. A slight to marked change in out 1 ine angle is usually associated with reworking. On many specimens reworking is unifacial, giving one or both edges a beveled appearance; steep 1 y beveled edges are rare, and alternate beveling is not present. Several specimens are slightly or markedly asymmetrical.

\section{IN7. Group 7 - Small Triangular (26 specimens)}

Group 7 thin bifaces are relatively small triangular bifaces. Outlines are triangular (Form 1) and subtriangular (Form 2). Both forms have specimens resembling narrow isosceles triangles, equilateral triangles, and variations in between. Some Group 7 specimens fit within established "arrow point" types such as the Fresno and Young types (Suhm and Jelks 1962). However, it is be 1 ieved that Group 7 thin bifaces represent preforms for arrow points such as Scallorn and Edwards (arrow point Group 2, Forms 1 and 2). 0ther researchers have presented similar interpretations (Highley et a.1. 1978:156). Several lines of evidence seem to support this statement. Out of 26 specimens, only six are complete, and one of these was found in two pieces. of the remaining five complete specimens, four have flaws or thick spots preventing final thinning. No impact fractures occur; virtualiy all fractures appear to be related to manufacturing failures. In addition, the final logical step in making Scallorn and Edwards arrow points involves notching and basally modifying thin triangular preforms (in this case, Group 7 thin bifaces). One specimen ( $F i g .14, g$ ) seems to illustrate this process; a smal1 notch has been started in one corner. Group 7 thin bifaces appear to be $f l$ ake bifaces as suggested by a number of specimens exhibiting flat remnants of the original ventrally flaked surfaces. A 71 Group 7 thin bifaces are pressure flaked.

TN7:1. Form I - Triangular (14 specimens)

Group 7, Form 1 thin bifaces have straight to slightly convex blade and basal edges. Two of the thickest specimens are beveled on both blade edges of one face, perhaps as an attempt to thin the artifact. 
TN7:2. Form 2 - Subtriangular (12 specimens)

Group 7. Form 2 thin bifaces have straight to 51 ightly convex blade edges, bases are convex, and corners are rounded.

IN8. Group 8 - Stemmed (14 specimens)

Group 8 thin bifaces are stemmed and appear to be preforms for dart points. Al i specimens appear unfinished and discarded due to breakage, material flaws, or extreme thickness.

TN8:1. Form 1 - Triangular B1ade--Contracting Stem (7 specimens)

B]ade shape of Group 8, Form 1 thin bifaces is broadly triangular approaching equilateral. The stem is contracting with a rounded base. This form resembles the Almagre type, a "large stemmed point" (Suhm and Jelks 1962:161\%. Form 1 specimens are obvious 1 y unfinished bifaces that appear to represent Langtry (dart point Group 3, Forms 2 and 3) preforms in severa? "stages" of completion. Group 8, Form 1 thin bifaces vary from an a 1 most diamond-shaped artifact (Fig. 15,a) with a poorly developed stem to we11developed stem specimens (Fig. 15,d,e).

TN8:2. Form 2 - Miscellaneous Contracting Stem (5 specimens)

Group 8. Form 2 thin bifaces have 1 anceolate or indeterminate blade outlines, and the stens are poorly developed.

TN8:3. Form 3 - Expanding Stem (2 specimens)

B 1 ade out lines are broad and 1 anceolate on Group 8, Form 3 thin bifaces with what appear to be rudimentary side notches or expanding stems. These may represent preforms for Travis or Nolan points (see dart point Group 3 , Forms 6 and 7 ).

\section{Incomplete Thin Bifaces}

IN9. Grour 9-Small Proximal (5 specimens)

Group 9 thin bifaces are relatively smal1 proximal fragments. Projected outlines vary from lanceolate to leaf shaped to narrow triangular. Blade edges are straight, convex, or converging. Bases are straight to slightly convex. Flaking techniques include soft hammer and pressure flaking methods. Metric attributes are remarkably consistent; thickness ranges from $0.5-0.8 \mathrm{~cm}$ and width from 2.2-2.8 $\mathrm{cm}$. This group appears similar to Group 7 thin bifaces in function; however, the larger average size suggests that most represent preforms for small dart points, perhaps the Ensor type (D1:2). It is probable that some specimens if completed would have been further thinned 
and shaped into thin biface Group 7 triangular forms. Two specimens (Fig. 15,0) have an incipient corner notch.

IN10. Group 10 - Contracting Blade Proximal (29 specimens)

Group 10 thin bifaces are proximal fragments which have a contracting blade. The projected outlines of the fragments are subtriangular, and they appear similar to Group 5 thin bifaces. Two forms are defined on the basis of maximum width.

TN10:1. Form 1 - Narrow (maximum width $<4.0 \mathrm{~cm} ; 20$ specimens)

TN10:2. Form 2 - Broad (maximum width $>4.0 \mathrm{~cm} ; 9$ specimens)

IN11. Group 11 - Straight Base Proximal (43 specimens)

Group 11 thin bifaces have straight to slightly convex or concave bases, and b Tade edges are parallel, expanding, or convex. Projected out 1 ines where determinable are mostly lanceolate, with some approaching triangular. Some Group 11 thin bifaces particularly Form 1 specimens, may represent fragments of thin biface Group 1; however, most specimens appear broader and 7 ack marginal pressure flaking. The absence of complete bifaces similar to many Group 11 (especial1y Form 2) fragments suggests that Group 11 represents unfinished preforms of dart points or finished thin biface forms. Fracture patterning suggests that most are manufacturing failures. Material flaws or inclusions frequently occur in conjunction with broken edges. Flaking techniques include soft hammer and pressure flaking. Maximum width was used to establish two forms.

TN11:1. Form 1 - Narrow (maximum width $<4.0 \mathrm{~cm} ; 26$ specimens)

Pressure flaking is present on many Group 11. Form 1 specimens, especially the better-thinned specimens. Some specimens appear to be fragments cf TNI:2.

TN11:2. Form 2 - Broad (maximum width $>4.0 \mathrm{~cm}$; 17 specimens)

Surfaces on most Group 11, Form 2 specimens are covered with broad "bil 1et" flake scars. Marginal pressure flaking occurs less frequently than in Form 1. Few specimens appear to be finished.

IN12. Group 12 - Concave Base Proximal (12 specimens)

Group 12 thin bifaces have slightly concave bases, and the blade edges are parallel to convex. Projected blade out 1 ines are 1 anceolate or asymmetrical. 


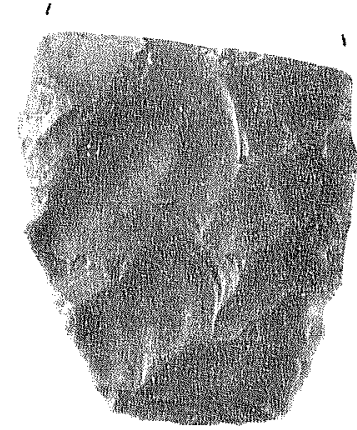

a

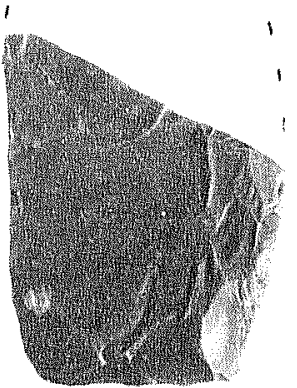

b

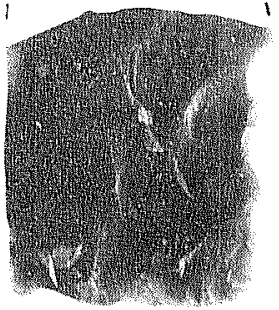

C

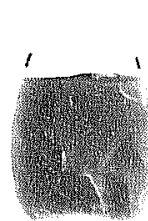

d

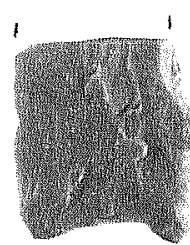

e
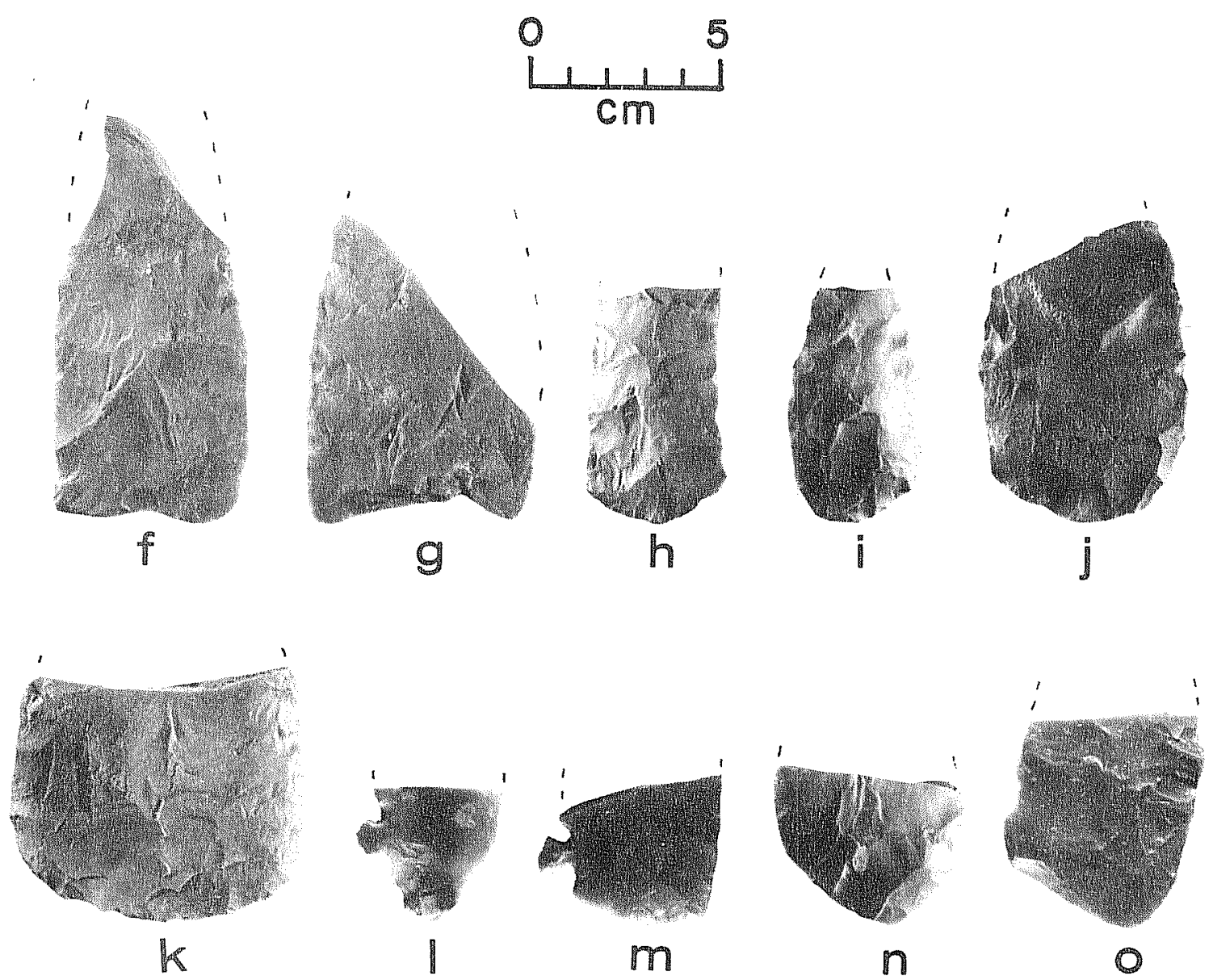

Figure 16. Thin Bifaces, Groups 11-15. a-c, TN11:2; d,e, TN12:1; f,g, TN12:2; $h, i$, TN13:1; $j, k$, TN13:2; 1, m, TN15:1; $n_{2} 0, T N 15: 2$. Lot numbers: a, G-1; b, 389; c, 78; d, 77; e, 330; f, 387; g, 390; h, 289; i, 391; j, 240; $k, 288 ; 1,38 ; m, 395 ; n, 395 ; 0,125$. 
Outlines, workmanship, and sizes are similar to TNII. Some specimens are obviously unfinished preforms. while others have minute marginal retouch suggesting possible use. Width was used to distinguish two fcrms.

TN12:1. Form 1 - Narrow (maximum width $<4.0 \mathrm{~cm} ; 5$ specimens)

TN12:2. Form 2 - Broad (maximum width $>4.0 \mathrm{~cm} ; 7$ specimens)

IN13. Group 13 - Convex Base Proximal (42 specimens)

Group 13 thin bifaces have convex bases (general1y not we 11 rounded), and blade edges vary from parallel to slightly contracting to slightly convex. Projected out 1 ines are 1 anceolate (especially Form 1) to leaf shaped. On most specimens, blade edges remain at or near maximum width for most of the length, as opposed to thin bifaces in Groups 3, 4, and 14, which have strongly convex lower blade edges. Width was used to define two forms.

TN13:1. Form 1 - Narrow (maximum width $<4.0 \mathrm{~cm}$; 23 specimens)

Projected out 1 ines for Group 13, Form 1 thin biface specimens are narrow lanceolate or leaf shaped.

TN13:2. Form 2 - Broad (maximum width $>4.0 \mathrm{~cm}$; 19 specimens)

Projected out 1 ines for Group 13, Form 2 thin biface specimens are broad 1 anceolate to almost cordiform.

IN14. Group 14 - Rounded Base Proximal (59 specimens)

Thin biface Group 14 specimens are rounded fragments which appear to be proximal biface sections. Basal and blade edges are moderately to strongly convex. Projected blade outlines are difficult to estimate; however, most would appear to be fragments of TN3 or TN4. Some specimens may over 1 ap Group 13, but blade edges are not extensive enough to make a determination. Flaking techniques, size, and workmanship vary considerably, but the majority of Group 14 specimens appear to be unfinished bifaces broken during manufacturing. Maximum width exceeds or would have exceeded $4.0 \mathrm{~cm}$ on most specimens.

IN15. Group 15 - Asymmetrical Proximal (6 specimens)

Group 15 thin biface specimens are separated into two forms of asymmetrical proximal fragments. 
TN15:1. Form 1 - Tanged (2 specimens)

Group 15, Form 1 contains two thin biface fragments with definite tangs. One specimen ( $\mathrm{Fig} .16, \mathrm{~m}$ ) is a we11-worked proximal fragment of a distinctive artifact referred to as a "corner-tanged knife" (Patterson 1936). This unusual artifact has been found in widespread Archaic contexts in central Texas (Hall 1981). The second specimen ( $F$ ig. 16,1) has some bifacial modification but appears to be basically a tanged flake. The edge opposite the tang appears damaged, perhaps by use.

TN15:2. Form 2 - Blunt Pointed (4 specimens)

Group 15, Form 2 thin bifaces are proximal fragments with bases that come to a blunt point off-center. Two of these appear to be slanted, and one (Fig. 16,n) has unifacial retouch along the slanted base.

TN16. Group 16 - Miscellaneous Eragments (693 specimens)

A wide assortment of fragments which cannot be sorted into projected forms represents Group 16 thin bifaces. Size, shape, flaking technique, and workmanship vary considerably. This group has little apparent diagnostic potential save for indicating areas of biface breakage or discard.

TN16:1. Form 1 - Distal (321 specimens)

Group 16, Form 1 thin bifaces are pointed fragments that are assumed to be distal fragments except those that are obviously arrow points or dart point fragments.

TN16:2. Form 2 - Medial (103 specimens)

Group 16, From 2 thin bifaces are apparent midsection fragments.

TN16:3. Form 3 - Miscellaneous (269 specimens)

Group 16, Form 3 thin biface specimens include Tateral sections, irregular proximal sections, and numerous fragments which could not be placed in any of the above forms or groups. Heat fracturing is frequent, and pressure flaking is rare.

\section{Projectile Points}

Projectile point is a functional term widely used in Texas and in North America in genera1. The term is applied to pointed thin bifaces (and occasionally unifaces) which have lateral or basal modification to facilitate hafting. Projectile points include spear, dart, and arrow points that were 
affixed (hafted) to the end of a wooden shaft and presumably used for piercing. The presence of projectile points is usually considered to indicate hunting activity. The problem of assigning the functional terms projectile point, dart point, or arrow point to chipped stone tools is that, without a detailed wear pattern analysis, it is impossible to distinguish between artifacts used for piercing and similar artifacts used for a variety of other functions (see Ah1er 1970; Nance 1971). Ahler's outstanding study of projectile points from Rodgers Shelter in Missouri clearly illustrates this problem. Ahler (1970) identified nine functionally separate groups among the "projectile points" he studied; only $22 \%$ of the sample was interpreted as having functioned exclusively as projectile points.

Lespite the obvious functional inaccuracy of the term projectile point, it remains $v a 1$ id as a morphological term which denotes a distinctive set of chipped stone tool forms. A considerable amount of effort and time in Texas archaeology has been and is being devoted to the collection, comparison, and description of projectile points. Despite criticism that this emphas is has neglected many other potentially informative artifact classes, the projectile point remains the most reliable chronological marker for most of Texas prehistory.

\section{Projectile Point Typology}

The problem of how to separate projectile points into culturally meaningful groups or types has long $\mathrm{plagued}$ Texas archaeology. Part II of the Handbook of Texas Archeology (Suhm, Krieger, and Jelks 1954) and a slightly revised reissue (Suhm and Je1ks 1962) were published as preliminary attempts to standardize pottery and projectile point types. The authors clearly recognized their work was on $1 y$ a beginning and not the final word: "It is expected that a 11 of them [types] will require future modification of une sort or another, some more so than others" (ibidasij). They further stated that the Handbook should not be used as a guide for identifying artifacts by comparison to illustrations but must be used by considering the full definition of the type. They believed types should have cultural and historical meaning in addition to morphological similarity. Thus, each type should have morphological, temporal, and geographical implications.

Since the Handbook was published, there has not been any systematic attempt. to revise and improve type definitions. Some definitions have been revised by more recent work, but typically such revision has been 1 imited to the use of multiple variations of defined types (i.e., Ensor I, II, and III) for specific sites. Usually Ensor II at one site is not the same as Ensor 2 at another site. An equally confusing practice is the use of terms such as Bulverde- 1 ike to indicate a partial similarity to the type definitions. Some new types have been defined or proposed, but only rarely do the descriptions contain the full range of information and cultural implications that Suhm and Jelks (1962) suggest should be provided. The end result is that projectile point typology in Texas has remained somewhat stagnant during the 1 ast 20 years. Point typology remains as much a subjective art as an objective too?. 


\section{Projectile Point Description}

Projectile points are divided into two major functional categories: arrow points and dart points. Arrow points are generally much smaller than dart points (usually weighing less than $2.5 \mathrm{~g}$; see Fenenga 1953) and were hafted onto arrow shafts and prope 11 ed by a bow. The introduction of the bow and arrow, however, comes relatively 1 ate in the regional cultural sequence. Dart points are, in general, considerably 1 arger than arrow points; presumabiy they were hafted onto short throwing spears and propelled by an atlat1. It is possible that some dart points were actual ly used with handheld spears or in some other functional capacity. The 1 argest arrow points and smallest dart points slightly overlap in size and weight. (Thomas 1978); they may also overlap in function.

With in each category various forms are described in groups. These groups are for the most part based on morphological similarities, although most groups have chronological implications as we11. Groups 3 and 7 are catchal1 groups in which a variety of morphological forms are described. Each form was determined to have distinctive morphological attributes that set it apart from other forms. As a general rule, patterns were looked for among the projectile points, and the splitting of each form into variations based on subtle differences was purposeful1y avoided. In reviewing regional literature, it was noted that many archaeologists seemingly concentrate on dividing projectile points into as small a group as possible. With a few rare exceptions, these variations (i.e., Pedernales I, II, III, IV, and V) have not been demonstrated to have any chronological or geographical significance. The concentration here is on describing forms which can be readily distinguished and readily duplicated by other researchers using the same criteria.

An attempt is also made to provide similar information for each form by using standardized terminology and a consistent format. Whenever possible, previously defined type names are used along with a citation of the original or most common 1 y accepted type descriptions. Concentration is placed on types that have caused typological problems, and type descriptions are revised where necessary. A number of forms do not fit previously defined types or they fit a number of type names. In these cases, descriptive titles, which should not be viewed as new type names, are used. Emphasis is a 1 so placed on forms with the largest number of specimens, as they usually vary more and are significant because of their frequency.

Arrow points were divided into three groups and dart points into eight groups. The following is a 1 ist of the group and form classifications for projectile points.

Arrow Points

Al. Group 1 - Contracting Stem Arrow Points, Perdiz

A2. Group 2 - Expanding Stem Arrow Points

A2:1. Form 1 - Edwards

$A 2: 2$. Form 2 - Scallorm

$A 2: 3$. Form 3 - Unnamed

A2:4. Form 4-Toyah 
A3. Group 3 - Miscellaneous Arrow Point Fragments $A 3: 1$. Form 1 - Distal Fragments

$A 3: 2$. Form 2 - Midsections and Basal Fragments

Dart Points

D1. Group 1 - Side and Corner-Notched Triangular

D1:1. Form 1 - Frio

D1:2. Form 2 - Ensor

D1:3. Form 3-Fairland

$D 1: 4$. Form 4 - Unnamed

D1:5. Form 5 - Unnamed

D1:6. Form 6 - Unnamed

D1:7. Form 7 - Unnamed

D1:8. Form 8 - Unnamed

D1:9. Form 9 - Darl

D1:10. Form 10 - Edgewood

D2. Group 2 - Broad Triangular with Expanding Stems

D2:1. Form 1 - Montel1

D2:2. Form 2 - Castroville

D2:3. Form 3 - Marsha11

$\mathrm{D} 2: 4$. Form 4 - Lange

$\mathrm{D} 2: 5$. Form 5 - Marcos

$\mathrm{D} 2: 6$. Form 6 - Villians

D3. Group 3 - Miscellaneous Stemmed

D3:1. Form 1 - Pedernales

$\mathrm{D} 3: 2$. Form 2 - Langtry

D3:3. Form 3 - Unnamed

D3:4. Form 4 - Bulverde

$\mathrm{D} 3: 5$. Form 5 - "Stubby"

D3:6. Form 6 - Travis

D3:7. Form 7 - Nolan

D3:8. Form 8 - La Jita

D3:9. Form 9 - Unnamed

D3:10. Form 10 - Pandale

D3:11. Form 11 - Bell

D4. Group 4 - Early Expanding Stem

D4:1. Form 1 - Unnamed

D4:2. Form 2 - Unnamed

$\mathrm{D} 4: 3$. Form 3 - Martindale

D5. Group 5 - Lanceolate/Leaf Shaped

D5:1. Form 1 - Angostura

D5:2. Form 2 - "Longitudinally Thinned"

D5:3. Form 3 - Miscellaneous Lanceolate to Leaf Shaped

D6. Group 6 - Unstemmed Triangular

D6:1. Form I - Kinney

D6:2. Form 2 - Carrizo

D6:3. Form 3 - "Thinned-Base Earty Triangular"

D7. Group 7 - Miscellaneous Forms

D8. Group 8 - Miscellaneous Unidentifiable Fragments

D8:1. Form 1 - Midsections, Barbs, and Lateral Fragments

D8:2. Form 2 - Basal Fragments 


\section{Projectile Point Attribute and Provenience Data}

Metric and nonmetric attribute data were recorded for 566 of the reconstructible projectile points recovered from 41 BX 228. These data were recorded on a revised version of the Artifact Quantification Coding Form developed by Joel Gunn and Elton Prewitt (1975). The revised form, the Projectile Point Coding Form (Appendix V:Fig. 65) includes nonmetric data not considered by Gunn and Prewitt's automatic point classification system. Appendix $V$ also contains coding instructions and attribute definitions for the Projectile Point Coding Form as well as a data table for the 566 reconstructible projectile points.

A statistical analysis of the projectile point data was not conducted. Benfer and Benfer (1981) have recently criticized the approach of Gunn and Prewitt (1975) to automatic point classification. The present author did not attempt automatic point classification primarily because of a 1 ack of understanding multivariate analysis. The data are provided in Appendix $V$ for comparative purposes; perhaps other more statistically we11-versed researchers will analyze the 41 BX 228 projectile point data set. A11 recorded reconstructible projectile points were assigned a three digit coding sequence number. A 1 ist of the coding sequence numbers assigned to each projectile point group and/or form is included with each point type/form description.

The provenience of a given projectile point can be determined for a 11 reconstructible points by reference to the data table in Appendix $V$. Nonreconstructible points (i.e., those points not assigned a coding sequence number) are 1 isted by lot number within each point type and/or form description. The provenience of these points can be determined by referring to the Lot Number Index (Appendix IV).

\section{Arrow Points (A)}

Al. Group 1 - Contracting Stem Arrow Pointse Perdiz (14 specimens: Fig. $17, a-f)$

Description: Blade outline is generally triangular and varies from very narrow isosceles to equilateral. Blade edges are straight to concave or slightly concave. The contracting stem is usually very narrow and pointed, occasionalty rounded. Shoulders are well developed, usually forming distinctive barbs. Blade edge serration and beveling occur occasionally. Heat treatment is present on several specimens. Flaking varies from very fine to crude.

Comments: Perdiz points at 41 BX 228 were made on flakes; flat ventral flake surfaces present on many specimens are often on 7 y marginal $7 y$ trimmed. These fit the type description of Suhm and Jelks (1962:293).

Chronological Placement: Perdiz points occur 7 ate in the prehistoric sequence. Jelks (1962) associates Perdiz points with the Toyah phase, dating from approximate1y A.D. 1300-1600. Numerous radiocarbon dates in south and 


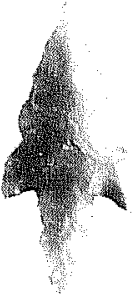

a

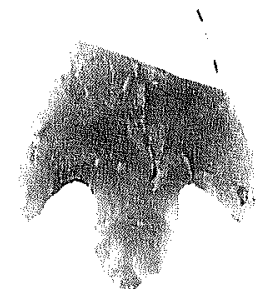

b

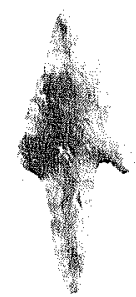

c

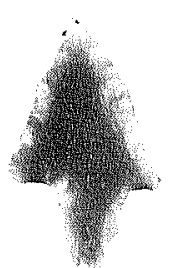

d

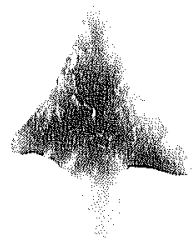

e

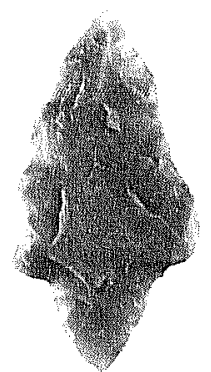

$f$

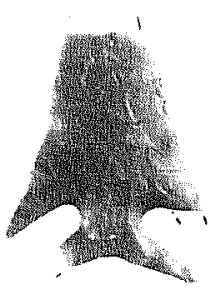

m

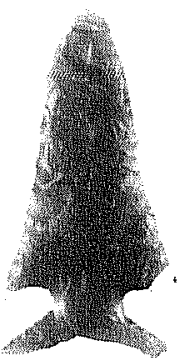

g

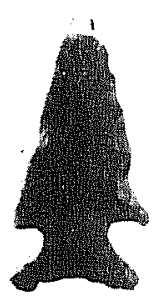

$\mathrm{h}$

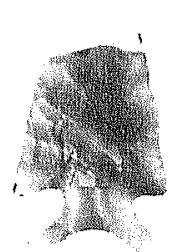

i
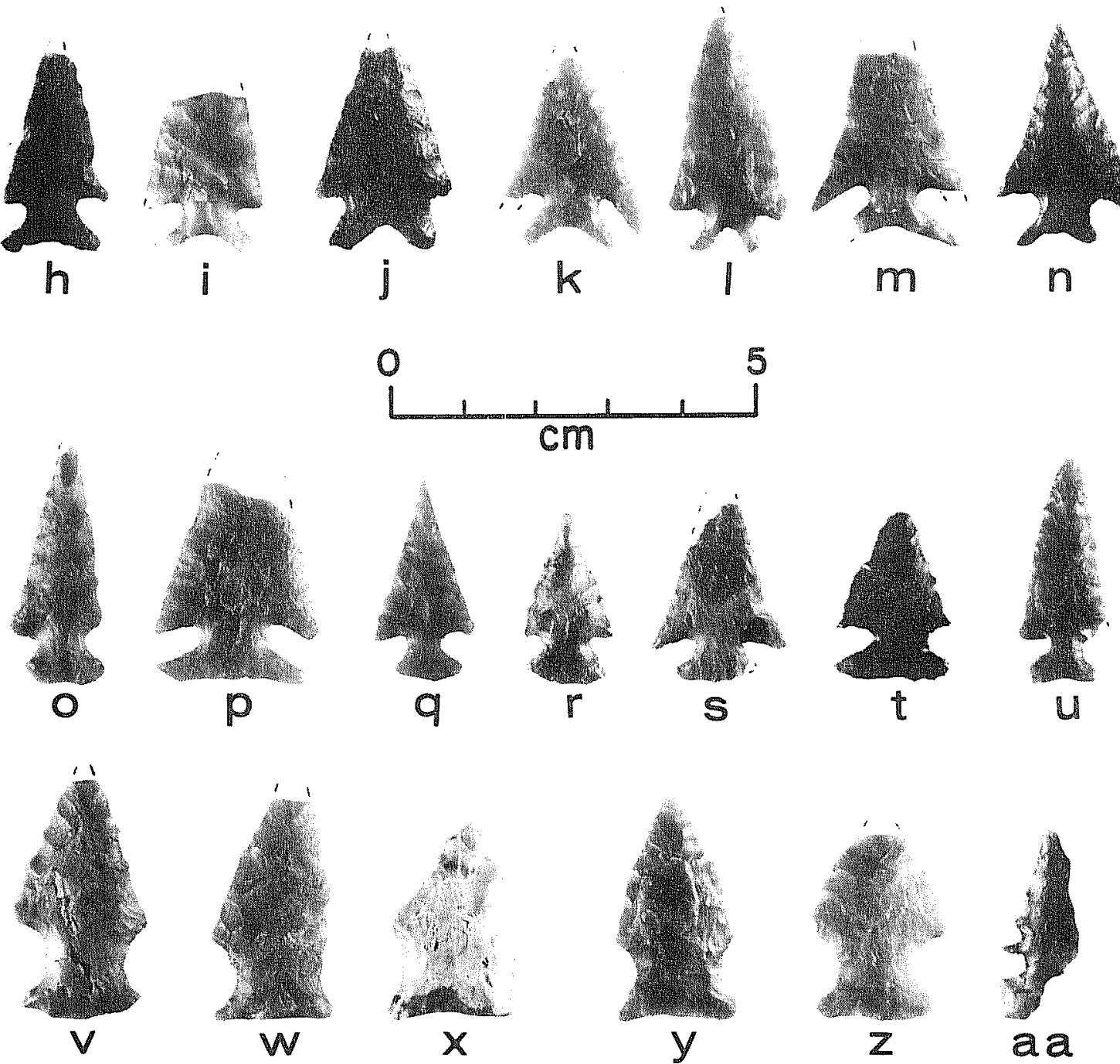

Figure 17. Arrow Points. a-f, Al, Perdiz; g-n, A2:1, Edwards; o-u, A2:2, Scallorn; $v-z, A 2: 3$; aa, $A 2: 4$, Toyah. 
central Texas have confirmed this dating. Perdiz points have been found in positions stratigraphically superior to Scallorn and Edwards arrow points at a number of sites. Local Period 11.

Coding Sequence Numbers: 386-399.

\section{A2. Group 2 - Expanding Stem Arrow Points (54 specimens)}

A2:1. Form 1 - Edwards (23 specimens; Fig. 17.g-n)

Description: Blade outline is triangular; edges are usually straight but occasionally concave or convex. Shoulders are well developed, ranging from right angled to downturned with prominent barbs. The stems expand rapidiy, forming flaring bases. The stem always has symmetrical barblike downturned projections forming a concave base. The base varies from wide, shallow, and slightly concave to deep, narrow, and $V$-shaped. Slight serration is present on several blade edges. Workmanship is good to exceptional. Heat treatment is present on many specimens.

Commerts: Sollberger (1967) believes Edwards points were modeled on a variety of central Texas dart points including Martindale, Fairland, Ensors Frio, and others. Edwards points are considered to be the 1 argest central Texas arrow point type (ibid.), although the 41 BX 228 specimens are in general not much larger than most Scallorn points. Shallow. concave-based Edwards and the widembased Scallorn specimens appear very similar. See Highley et a1. (1978:150) for an excellent discussion of the Edwards point.

Chronological Placement: Sollberger (1967), Hester (1970), and others have suggested that Edwards points were the earl iest arrow point in the southcentral Texas area. Radiocarbon dates indicate the type appeared by A.D. 900-1000 (Hester 1971; Gerstle, Kelly, and Assad 1978). Local

Period 10(?).

Coding Sequence Numbers: 400-413, 415-419.

Uncoded Lot Numbers: $46,62,63$, and 257.

A2:2. Form 2 - Scallorn (24 specimens; Fig. 17,0-u)

Description: Blade outlines are triangular--some very narrow and others comparatively wide. B 1 ade edges are very straight. Shoulders are we 11 developed, usually forming a right angle, but occasionally slightly downturned, forming barbs. Distinct side and corner notching form strongly expanding stems. Stems are usually as wide or wider than the blade. Bases are generally very straight; occasional specimens have a slight concavity or convexity. Slight blade serration is present on several specimens. Workmanship is good to excel 1ent. Heat treatment is present on approximately one-half of the specimens. 
Comments: These points fit Je1ks (1962:30) Scallorn sattler variety. A similarity to Edwards points is obvious.

Chronological Placement: Jelks (1962) associates Scallorn points with the Austin phase, which is dated at approximately $A_{0} D$. 1000-1300, although Prewitt (n.d.) believes the Austin focus begins around $A_{0} D .700$. While Scallorn points have been frequently found below Perdiz points, the stratigraphic relationship with Edwards points is unclear. Loca 7 Period 10.

Coding Sequence Numbers: 420-435.

Uncoded Lot Numbers: 44, 58, 92 (two specimens), 304, 311, 431, 436.

A2:3. Form 3 - Unnamed (6 specimens; Fig. 17, v-z)

Description: These specimens have triangular blades with straight to convex blade edges and distinct but not barbed shoulders. Shallow, wide side notches form wide expanding stems. Bases are straight to slight $7 y$ concave or convex.

Comments: Group 2. Form 3 arrow points resemble very smal1 Ensor points, but the smal1 size suggests that they are arrow points. A similar specimen is i17ustrated in Prewitt (1974:Fig. 16,dd).

Chronological Placement: Unknown; probably Late Prehistoric. Local Period 10(?).

Coding Sequence Numbers: 477-479.

Uncoded Lot Numbers: D-3, 162, 388 .

A2:4. Form 4 - Toyah (1 specimen; Fig. 17,aa)

Description: This specimen has a partially serrated small triangular blade and is side notched approximately one-third of the length from the base. The base is straight with a central deep notch. The side and basal notching leaves a bifurcated stem which has the appearance of two squared-off ears.

Comments: Toyah arrow points are rare in central Texas. They are more common in the Trans-Pecos region and numerous in northeastern Mexico (Heartfield 1980).

Chronological Placement: Late Prehistoric and Protohistoric. At Cueva de la Zona de Derrumbes in Nuevo Leon (MCClurkan 1980), Toyah points were placed in Pericd V (post-A.D. 800). Heartfield (1980:75) has suggested that Toyah and a number of other arrow point types may date to Protohistoric or Historic occupations in southwestern Coahuila.

Coding Sequence Number: 385. 
A3. Group 3-Miscellaneous Arrow Point Fragments $(59$ specimens; not illustrated)

A3:1. Form 1 - Distal Fragments (38 specimens)

Form 1 of Group 3 arrow points are sma 11, thin bifacially chipped pointed fragments. Most probably represent the distal portions of arrow points; some may also be Perdiz (Al) stem fragments or tips from exceptionaliy thin dart points.

A3:2. Form 2 - Midsections and Basal Fragments (21 specimens)

Form 2 of Group 3 arrow points are sma 11, thin fragments identifiable as arrow point sections. Most are blade sections missing lower stems and bases. A1 1 Form 2 specimens are probably fragments of arrow point Groups 1 and 2 (AI and $A 2)$.

\section{Dart Points (D)}

\section{D1. Group 1 - Side and Corner-Notched Triangular (102 specimens)}

Group I dart points include a number of forms which can be attributed to Local Period 9 (Transitional Archaic or Twin Sisters phase), dating to approximately A.D. 200-700. This form shares in common the following attributes: (1) relatively smal1 size in comparison to dart point Group 2 forms which immediately precede Group I chronologica $11 y$; (2) triangu 1 ar b 1 ade out lines; (3) all have side or corner notches forming expanding stems; and (4) a 11 occur at about the same time.

Group l, like other groups, varies considerably in all of the above attributes, resulting in typological problems since many types grade into each other. The Frio and Ensor point types have frequently caused prob lems, leading this writer to revise the Frio type to eliminate most of the confusion. Several of the forms have not been previously typed and cannot be considered we 11 dated; however, they appear to occur at or about the same time. Weir (1976a:118) believes that it was probab7y during the Twin Sisters phase that true arrow points were first introduced into the area. It has been suggested that certain Group I forms served as models for early arrow point styles (Sollberger 1967). Certainly some of the smaller Group 1 points approach arrow point size.

\section{D1:1. Form 1 - Frio (revised description) (37 specimens; Fig. 18,a-f)}

Description: Blade outline is triangular, usually narrow triangular; blade edges are straight or slightly convex or concave and sometimes serrated. The shoulders are prominent and either squared off or downturned, forming short barbs. A 17 points have U-shaped side or corner notches, giving the stem a widely flaring (expanded) appearance. A central basal indentation or notch varying from a deep U-shape to a broad shallow notch to a small very shallow 


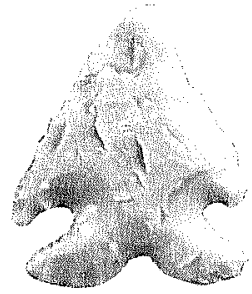

a

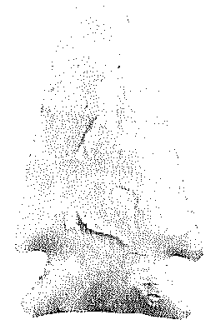

g

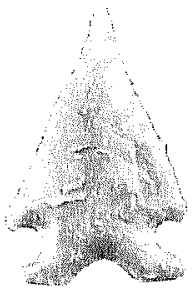

b

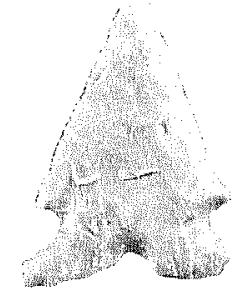

C

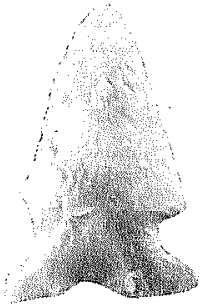

d

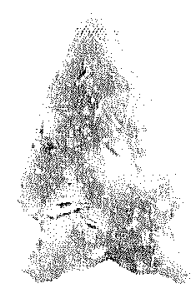

e

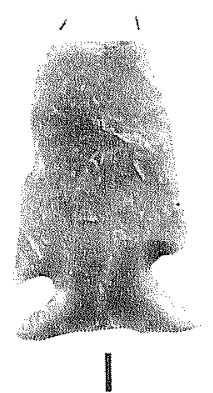

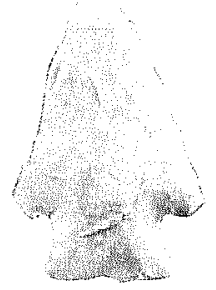

f

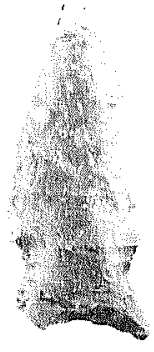

m

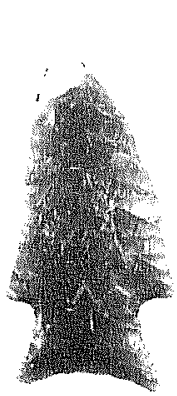

n

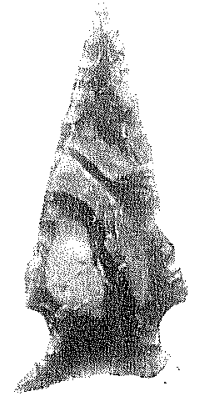

O

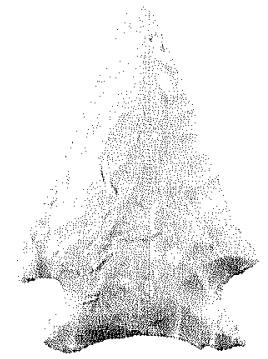

$p$

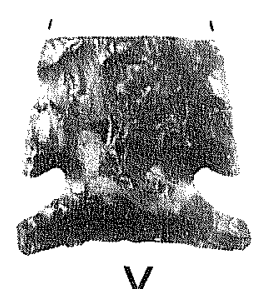

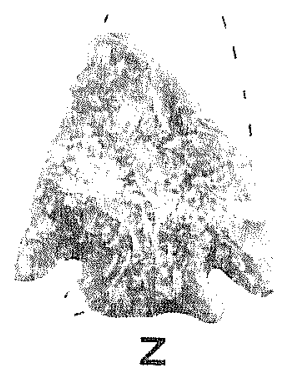

U
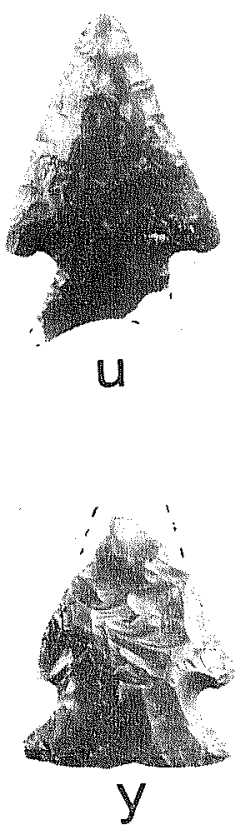

Figure 18

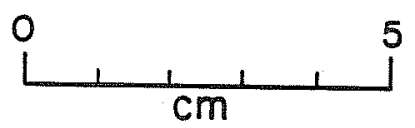

5

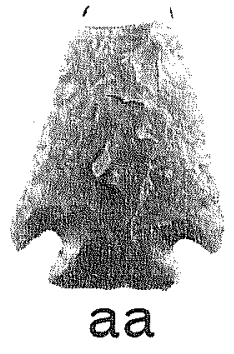

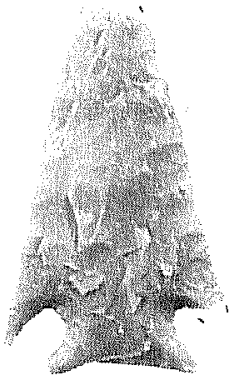

r

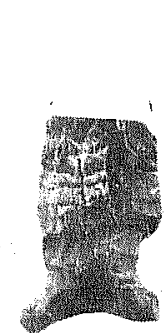

S

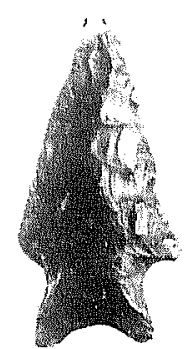

$t$

D1:3, Fair 1 and $P-r, 01.4,5-4,01.5, v$, Dl:9, Dar 1; cc,dd, DI:10, Edgewood. 
notch is always present. The combination of side or corner notching and basal notching gives the Frio point its distinctive bifurcated stem. The bifurcated stem is symmetrical, although some minor variation between the two halves usually occurs. The shape of the stem varies considerably, as discussed. The width of the base is usually equal to or wider than the blade: rarely, the base is slightly narrower than the blade. Workmanship is consistently good to excellent; Frlo points are invariably thin and symmetrical, with straight regular edges when viewed on edge. Heat treatment occurs on many specimens.

Comments: It has long been recognized that a number of variations of Frio and Ensor points exist in addition to those il lustrated in Suhm and Jelks (1962). These have been dealt with by dividing Ensor into variants as Johnson, Suhm, and Tunne11 (1962:21), Tunnel1 (1962:88-90), and others have done or by using hyphenated names 1 ike Ensor-Frio (Gerst1e, Kel1y, and Assad 1978) or Frio-Ensor or "Frensor" as they have often been informal 1y called. None of the many variations that have been described have been shown to have any chronological separation--in fact they are always attributed to the same period. To offer a solution to the confusion between the various contemporary side- and corner-notched expanding stem points, it is proposed that straight- or convex-based variants be called Ensor and indented base variants Frio. The author believes that the variations reflect idiosyncratic differences that cannot be temporally or even geographically separated.

Chronological Placement: Frio points, Ensor points, and variations thereof have been comparatively we 11 dated. They are diagnostic of the Transitional Archaic or the Twin Sisters phase (Weir 1976a; Prewitt n.do), dating to A.D. 200-700 in north-central Texas. In south-central Texas, the dates seem to run perhaps to A.D.950 (cf. La Jita [Hester 1971:121]). At 41 BX 228, a number of dates ranging from $A_{\circ} D .910-1020$ may be applicable to Local Period 9.

Coding Sequence Numbers: 146-149, 151-169, 171, 172, 192-195, 204, 209, and 559.

Uncoded Lot Numbers: $86,116,212,467$, and 481.

\section{D1:2. Form 2 - Ensor (30 specimens; Fig. 18, g-1)}

Description: Triangular blade outlines: narrow triangular are more common than broad triangular. Blade edges are most often straight, occasionally convex, or rarely concave and may be slightly serrated. Shoulders are prominent and usual1y squared off or occasional1y downturned with short barbs. A11 Ensor points are notched. The notches range from shallow side notches to deeper corner notches forming an expanding base. The neck is usually comparatively wide, although corner-notched specimens have narrower necks. The base is basically straight, although it may be slightly convex or concave. Most specimens appear heat treated. Workmanship is generally good to excollont. 
Comments: See Frio point discussion. The above description falls within the type definition of Suhm and Jelks (1962:189).

Chronological Placement: See Frio point discussion. Local Period 9.

Coding Sequence Numbers: $136,173-191,197,210,215,216,414,471,474$, 475,483 , and 539.

\section{D1:3. Form 3 - Fairland (8 specimens; Fig. 18, m-o)}

Description: Triangular blades with convex to straight edges, sometimes fairly serrated. Prominent shoulders formed by shallow side notches; stem flares widely, as wide as or wider than the blade. Bases are strongly concave. Stem tips are sharply pointed. Bases are always well thinned. Workmanship is good to exceptiona1. One specimen ( $F i g .18, n)$ has paralle 1 ob 1 ique $\mathrm{fl}$ laking. Most specimens appear heat treated.

Comments: Fairland points are a minor central Texas dart point type. They occur rarely if at a 11 in the Pecos area or in deep south Texas. Other points with concave bases and flaring stems such as D1:5 may be related but lack distinctive flaking on stem and base. Group 1, Form 3 fits within Suhm and Jelks' (1962:191) definition for Fairland points.

Chronological Placement: Local Period 9, A.D. 200-700. Fairland points may occur near the end of this periods as Weir (1976a:118) notes that "Fairland and Darl components commoniy precede components bearing arrow-points."

Coding Sequence Numbers: 196, 198, 199, 206-208, 211, and 217.

D1:4. Form 4 - Unnamed (7 specimens; Fig. 18,p-r)

Description: Comparatively short, broad triangular blade; edges are straight to slightly convex or concave. Shoulders are prominent, usually forming short downturned barbs. Small notches originating at or just above the corners form expanding stems. Stems are short and very broad, usual1y a 7 most as wide as the blade. Bases are shallow concave. Workmanship is fair to excellent. Several specimens appear heat treated.

Comments: Form 4 dart points do not fit any previously defined type. They resemble Edgewood points but for the most part are larger, broader, and more strongly barbed. They also resemble Frio points but 1 ack a distinct basal indentation. Similar specimens at the Wunderlich site (Johnson, Suhm, and Tunnel 1 1962:30 and Fig. 8,D-F) were termed Provisional Type II.

Chronological Placement: Uncertain, Local Period 9(?).

Coding Sequence Numbers: 202, 481, 484, and 496 .

Uncoded Lot Numbers: 52 and 444. 
D1:5. Form 5 - Unnamed ( 6 specimens; Fig. 18, s-u)

Description: Small triangular blades; edges straight to convex. Shoulders slight to prominent with short barbs. Side notching varies from shallow notches to deeper notches angled toward corner. Stems flare as wide as or wider than blades. Bases are concave.

Comments: Group 1, Form 5 specimens are similar to Fairland, but do not have the distinctive flaking on the stem and base. They may be poorly made variants of the Fairland point.

Chronological Placement: Unknown; possibly the same as DI:3 (Fairland). Coding Sequence Numbers: $200,201,203,205$, and 465 .

Uncoded Lot Number: 303.

D1:6. Form 6 - Unnamed (3 specimens; Fig. 18, $v, w$ )

Description: Broad triangular blade with straight to slightly convex edges. Deep 7 y side notched with angles toward base. Short barbs. Wide neck with short, widely flaring stem. Base is shallow concave.

Comments: Similar specimens were termed Ensor Variety $E$ at the Oblate site by Tunne 11 (1962:90). Similar specimens were also found at 41 BX I (P.D. Lukowski, personal communication). Dl:6 points are quite distinct from $\mathrm{Dl}: 2$ (Ensor) points.

Chronological Placement: Uncertain, Local Period 9(?).

Coding Sequence Numbers: 213-215.

D1:7. Form 7 - Unnamed (2 specimens; Fig. 18,x,y)

Description: Short, broad triangular blade with convex edges. Side notched. Very wide expanding base that is straight to slightly convex.

Comments: Similar to specimens from the Oblate site termed Ensor Variety D (Tunne11 1962:90).

Chronological Placement: Uncertain, Local Period 9(?).

Coding Sequence Numbers: 472 and 489.

$\mathrm{Dl}: 8$. Form 8 ( 6 specimens; Fig。 $18, z, a a)$

Description: Short, broad triangular blade with straight to convex edges. Prominent barbed shou 1 ders. Narrow corner notches form a short expanding stem. Bases are slightly concave to straight. Most appear heat treated. 
Comments: $D 1: 8$ points resemble smal1 Marcos points.

Chronological Placement: Uncertain. Local Period 9(?).

Coding Sequence Numbers: $273,461,488,490,492$, and 495.

D1:9. Form 9 - Darl (1 specimen; Fig. 18,bb)

Description: Narrow triangular blade with straight edges. Squared-off shoulders. Short expanding stem. Slightly convex base. Excellent workmanship.

Comments: Fits Prewitt's (1974:87) Darl Variety IV except slight beveling only on left edge of one face of blade.

Chronological Placement: Darl points were we 11 dated at the Loeve-Fox site (Prewitt 1974) where they occur with Ensor points in the Twin Sisters phase or Transitional Archaic contexts. Local Period 9.

Coding Sequence Number: 57.

Dl:10. Form 10 - Edgewood (2 specimens; Fig. 18,cc,dd)

Description: Short triangular blade with convex edges. Prominent shoulders and expanding stem formed by smal1 notches from corner or side. Base is concave.

Comments: Fits Edgewood type (Suhm and Jelks 1962:163).

Chronological Placement: Uncertain: possibly Local Period 9.

Coding Sequence Numbers: 491 and 493.

D2. Group 2 - Broad Iriangular With Expanding Stems (134 specimens)

Dart point Group 2 specimens date to Local Period 8 (San Marcos phase or Late Archaic). The following point types are included: Castroville, Marshal1. Lange, Mil1 iams. Marcos, and Monte11. A11 are relatively broad and general1y have triangular outlines with prominent shoulders and expanding stems. Notching and basal modification account for most of the variation. Monte 11 points are readily distinctive and seldom confused with other types. Marcos, Wi11 iams, Castrovil1e, and Lange seem distinct when one compares classic or idealized examples, but when viewing the variants one finds considerable overlap. An excellent example of this overlap is Bone Bed 3 at Bonfire Shelter. Dibble (in Dibble and Lorrain 1968:51-54) classified 19 points as Castroville points, dividing the 19 points into five groups for descriptive purposes. His comments (ibid.:51) deserve repeating: 
As a group they are quite similar to the defined Castroville type (Suhm, Krieger, and Jelks 1954:408). However, some of those 7 umped together here vary in significant respects from the range stated for this category. Variants might we 11 have been compared with other described dart points such as Marcos. Marsha11. Shumla and williams.. . but it was felt that such a strict typological breakdown would too strongly imply cultural or chronological distinctions not apparent in this tightly associated collection.

Group 2 dart points were sorted into the defined type (form) which most clearly matches in definition. Due to the overall similarity of many of the forms as noted above, other archaeologists would no doubt sort them somewhat different1y. A11 appear to be roughly contemporaneous.

\section{D2:1. Form 1 - Montell (50 specimens; Fig. 19,a-c)}

Description: Blade outlines are triangular; blade edges are usually very straight, sometimes slightly convex. Shoulders are well developed and vary from squared off (occasional) to barbed; barbs are usually short and pointed. Stem expands slightly; a deep $U$ - or $V$-shaped basal notch forms a bifurcated stem. The base is strongly convex prior to notching. Heat treating is present on most specimens. Workmanship is excellent on most specimens.

Comments: Montel 1 points are a very distinct point type. The combination of the bifurcated stem, excel lent workmanship, and very thin appearance is easily recognizable. Group 2. Form 1 dart points fit wel1 within the definition of Montel 1 points in Suhm and Jelks (1962:219).

Chronological Placement: Montel 1 points are consistently attributed to the Late Archaic or San Marcos phase (Local Period 8) along with Castrovil le and Marcos points (Johnson, Suhm, and Tunnel1 1962:121). Montel1 points were found at Bonfire She ter (Dibble and Lorrain 1968) along with Castroville points in Bone Bed 3, $695 \pm 75$ B.C. (average uncorrected radiocarbon dates).

Coding Sequence Numbers: 001-032, 551, and 552.

Uncoded Lot Numbers: J2, 46, 65, 82, 85, 122, 131, 150, 191, 212, 240, 387 , $390,395,397$, and 450 .

\section{D2:2. Form 2 - Castroville (48 specimens; Fig. 19,d,f,g)}

Description: Broad, 1arge triangular blades; blade edges are usual1y extremely straight, occasionally slightly convex or concave. Strong, we 11developed barbs are formed by deep, narrow U- or V-shaped basal notches. Barbs are usually in 1 ine with the base but may be slightly above or below. Short broad stems expand s1ightly to marked1y; stem edges are usually straight. Bases are usually convex, occasionally straight, and rarely concave (two specimens). Distal blade portions often have blade angle changes and rounded tips resulting from resharpening. Workmanship is good to excellent. Smoothing often occurs on base and occasionally on stems. Broad, 


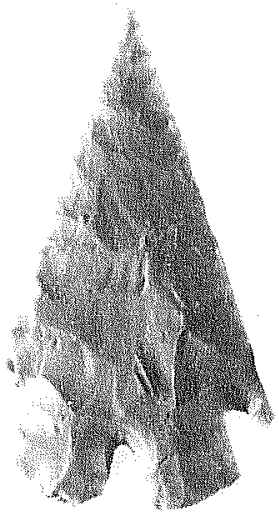

a
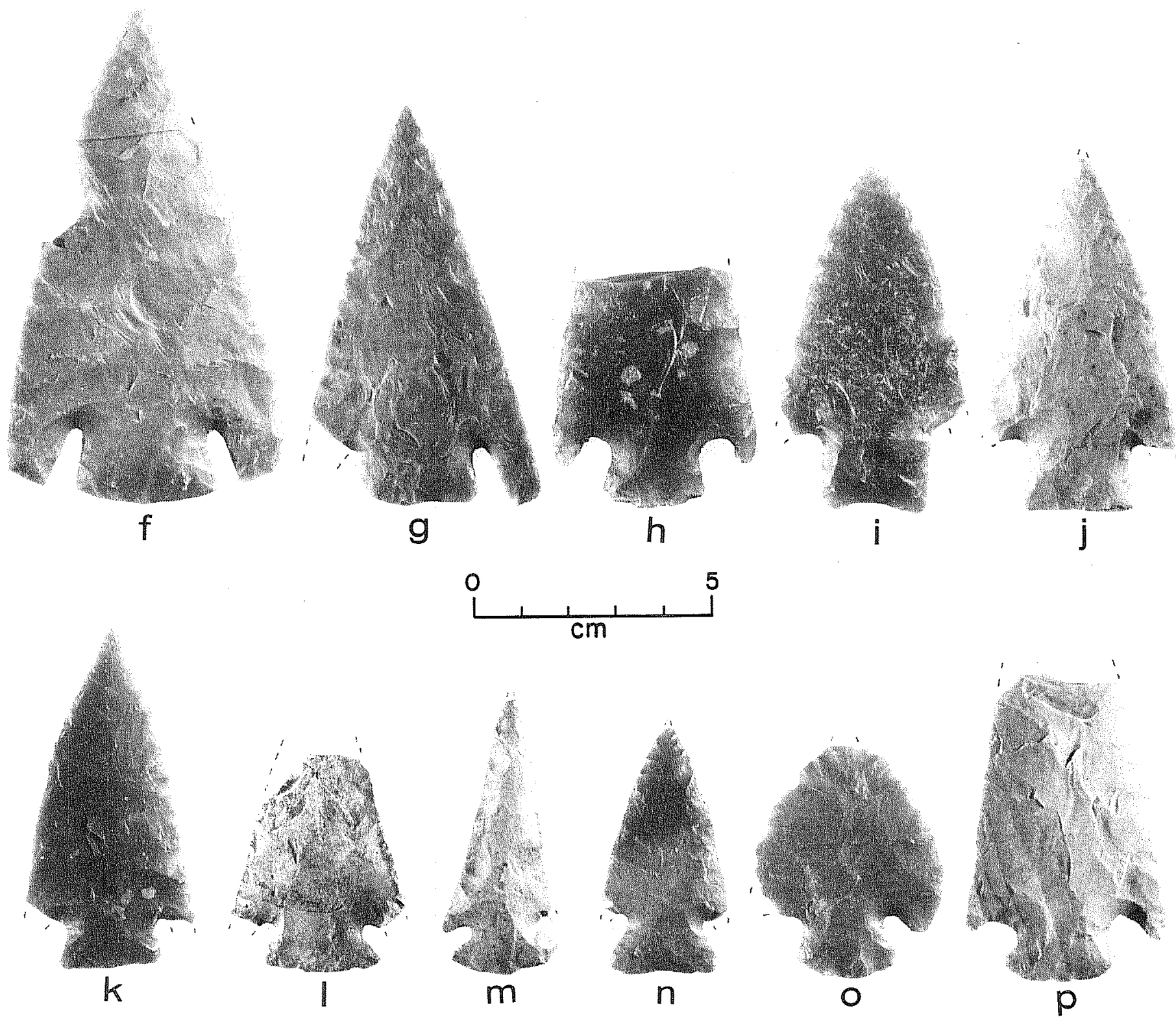

Figure 19. Dart Points, Group 2. a-c, D2:1, Monte11; d,f,g, D2:2, Castrovil1 le; $e, h, D 2: 3$, Marsha $11 ; i, j, D 2: 4$, Lange; $k-n, D 2: 5$, Marcos; $0, p$, D2:6, Wi11iams。 
shallow, random flake scars (soft hammer percussion) cover most of the blade faces; marginal trimming (pressure flaking) occurs along blade edges and along base and notches. Over half of the specimens have definitely been heat treated.

Comments: Most specimens appear to be blocked out first into triangular preforms with convex bases which were then basally notched as Suhm and Jelks (1962:173) note. Some Castrovil1e points are massive, suggesting to this author that they may have served as other than dart points (knives?). Affinity to Montel 1 points seems obvious; both are relatively large triangular points with good workmanship, relative thinness, basal notching, and a high degree of heat treatment, and they are chronologically contemporaneous.

Chronological Placement: Same as Montel1.

Coding Sequence Numbers: 033-056, 058-072.

Uncoded Lot Numbers: $X X, 10,44,103,330,380,391,395$, and 464 .

\section{D2:3. Form 3 - Marsha11 (14 specimens: Fig. 19,e,h)}

Description: Broad triangular blades; blade edges are convex to straight. Shoulders are prominent and always barbed. Barbs are usual 1 y short but large; occasionally barbs align with base; stems are relatively short, and are slightly expanded (rarely markedly) due to notches from the base or corners. Bases are straight or slightly convex or concave. Workmanship is good to excellent. Heat treatment is common.

Comments: Fits within Suhm and Jelks (1962:211) definition, which allows for considerable variation. Group 2, Form 3 dart points have some similarities to Castroville points, except stems are not as wide, blade edges are usual1y not as straight, and basal notches are wider and more rounded. Weir (1976a:135) speculates that Marshall points may have developed from Pedernales points $(D 3: 1)$ with stylistic influence from the Plains Archaic.

Chronological P1acement: Local Period 8. Marshal1 points may begin in the 1 ater part of Local Period 7 (Round Rock phase; ibid.), as they sometimes cooccur with Pedernales points (Keller 1976).

Coding Sequence Numbers: 264, 268, 278-284, and 436.

Uncoded Lot Numbers: G1, 142, 155, and 397.

D2:4. Form 4 - Lange (4 specimens; Fig. 19, $i, j$ )

Description: Large, broad triangular blades with convex blade edges. Shou 1 ders are prominent but 1 ack barbs. Stems expand with straight bases. One specimen has only a slightly expanding stem and a slightly convex base. 
Comments: Fits the type definition of Suhm and Jelks (1962:203). Similar specimens were termed "Castroville 2" by Sorrow (1969:16).

Chronological Placement: Local Period 8.

Coding Sequence Numbers: 263, 265, 267, and 473.

D2:5. Form 5 - Marcos (16 specimens; Fig. 19,k-n)

Description: Triangular blades, usually broad, occasionally narrow; blade edges are straight or s1ightly recurved or convex. Very prominent shoulders are always barbed due to deep corner notches. Stems expand markedly but are not as wide as the blade. Bases are usually convex, occasionally straight, or rarely slightly concave. Heat treatment is common. Workmanship is good to excellent.

Comments: Group 2, Form 5 dart points fit the type definition of Suhm and Jelks (1962:207), although the size varies somewhat.

Chronological Placement: Weir (1976a) attributes Marcos points to the San Marcos phase (Local Period 8).

Coding Sequence Numbers: 266, 269-272, 274-277, 466, 485-487, 499, and 558 .

Uncoded Lot Number: 380.

D2:6. Form 6 - Wi17iams (2 specimens; Fig. 19,0,p)

Description: Broad triangular or leaf-shaped blades with straight to strongly convex edges. Prominent barbed shoulders are formed by corner notches. Stems expand with a convex base. One specimen appears heat treated.

Comments: Group 2, Form 6 dart points fit the type description of Suhm and Jelks (1962:259).

Chronological Placement: Local Period 8.

Coding Sequence Numbers: 261 and 262.

D3. Group 3 - Miscellaneous Stemmed (258 specimens)

Dart point Group 3 is a catchall group of forms which do not share many attributes other than being stemmed. These forms can be attributed to Local Periods 5-7. 


\section{D3:1. Form 1 - Pedernates (114 specimens; Fig. 20,a-f)}

Description: Blade shape varies considerably from narrow triangular (most common) to broad triangular to leaf shaped. Blade edges are straight to convex to slightly recurved or concave. Shoulders are always present but vary from slight to prominent. Prominent shoulders vary from squared off to well barbed. The distinguishing feature of the Pedernales point is the stem. The stem is generally rectangular but also slightly expanding or contracting and usually has a distinctive U-shaped basal concavity. The base is thinned by removal of short longitudinal flakes from one or both faces. The base ranges from deep U-shaped to shal low concave. Workmanship varies from poor to excellent but is usually good. Heat treatment is common.

Comments: Pedernales points have been subdivided into three to five subgroups by various authors (cf. Sorrow, Shafer, and Ross 1967; Sorrow 1969; Johnson, Suhm, and Tunnel1 1962). To the best of this author's knowledge, no one has suggested that these subgroups or variations have chronological or geographic significance. Hence, Pedermales points are herein presented as a single group. Pedernales points are probably the most common point type in central Texas (Weir 1976a:110) and are frequently associated with burned rock middens.

Chronological Placement: Local Period 7, ca. 2000-600 B.C.

Coding Sequence Numbers: 073-135, 137-145, and 553.

Uncoded Lot Numbers: C5, D2 (two specimens), E7, P2, 15, 52, 53, 77, 127 , $138,143,149,151,166,169,180,184,223,244,279,289,302,331,386$ (two specimens), 387, 391 (two specimens), 394, 395 (two specimens), 396 (two specimens), $398,435,443,445$ (two specimens), and 446 .

\section{D3:2. Form 2 - Langtry (16 specimens; Fig. 20,g-i)}

Description: Blade outlines are broad triangular; blade edges are very straight, occasionally slight 1 y concave. Prominent shoulders are either right angled or slightly downturned, forming short barbs. Stems contract slightly to marked7y. Bases are narrow and straight, slightly concave, or slightly convex. Beveling occurs occasionally on blades or stems. Workmanship is good to excellent; most are very thin. Heat treatment is present.

Comments: Langtry points are very common in the lower Pecos River region where they have been divided by various researchers into four to six groups (Word 1970:28). While the exact combination of attributes varies considerab $7 y$, "the most sal ient characteristics of the Langtry points are (1) their triangular blade, (2) prominent shoulders, (3) long and generally contracting stems" (Johnson, Suhm, and Tunnel1 1962:23). Langtry points are similar to Shumla points, with which they are often found in association in the lower Pecos River region (Johnson 1964:38). Johnson (ibid.:42-43) al so notes that some varieties of Shumla have been classified as Gary points in Tamaul ipas (MacNeish 1958). The similarity between Langtry and Gary points, 


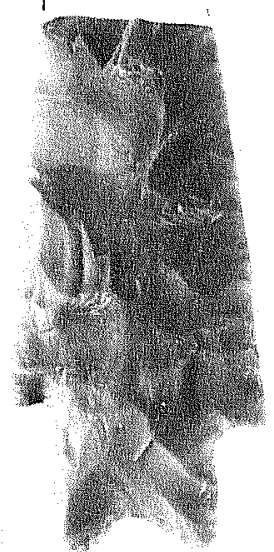

a

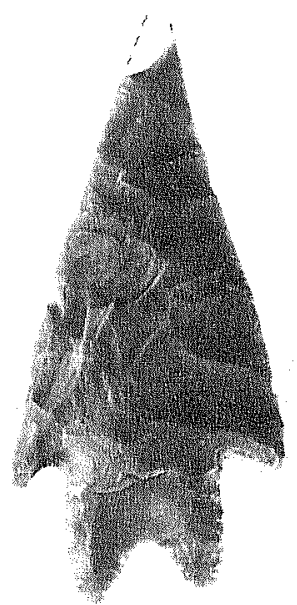

b

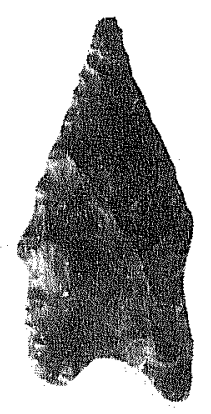

C

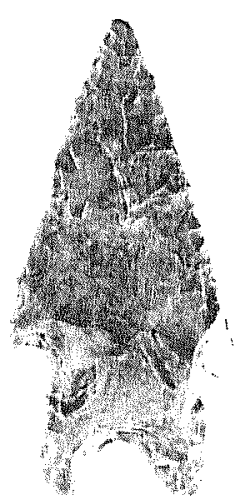

d

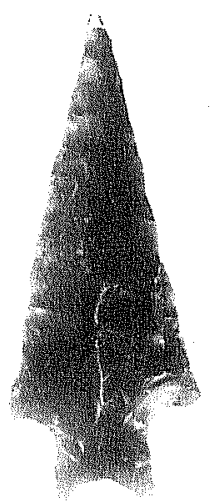

e

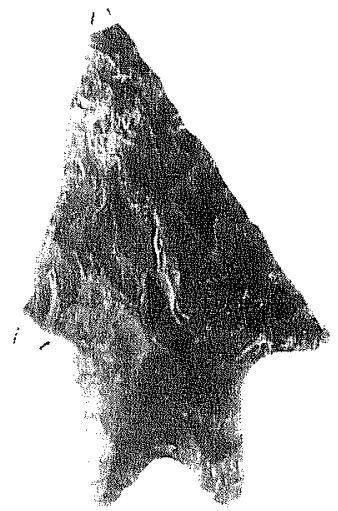

f

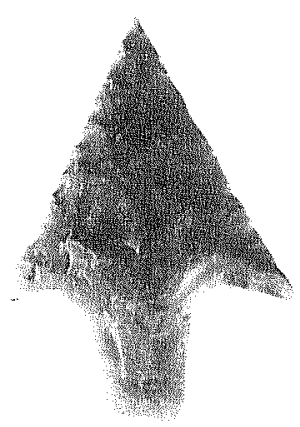

g

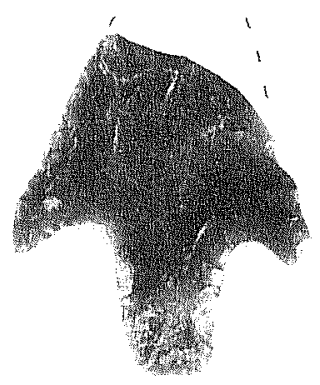

h
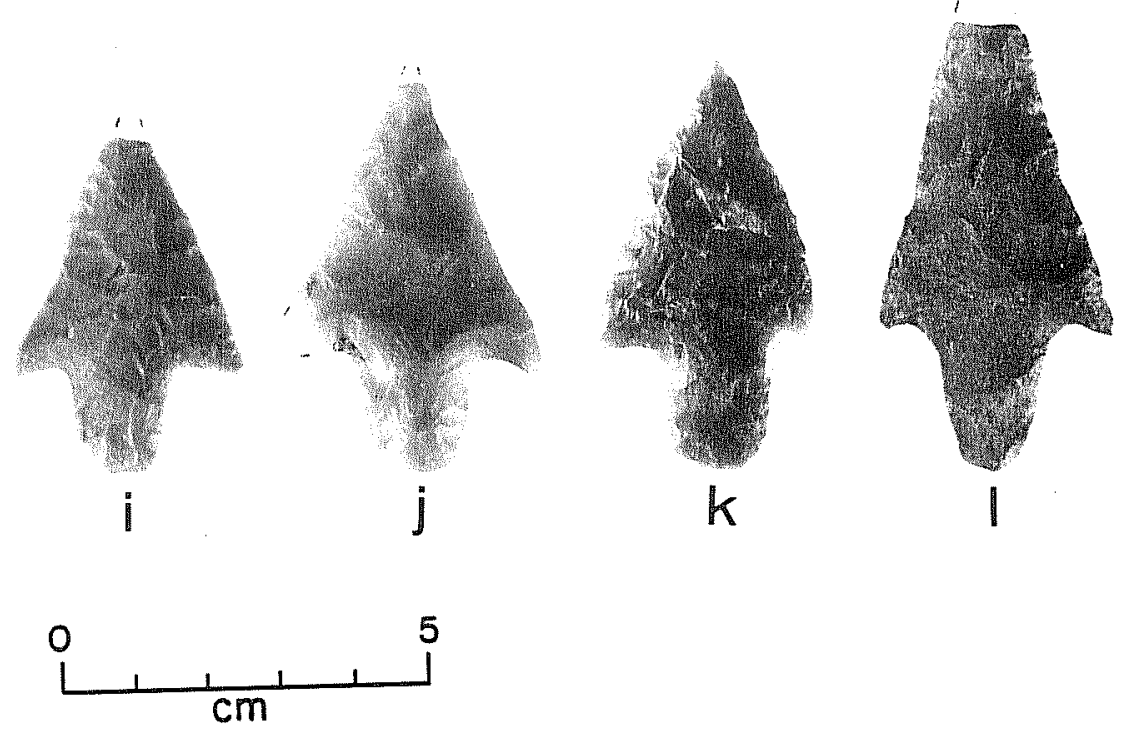

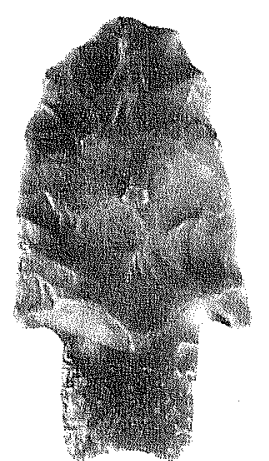

m

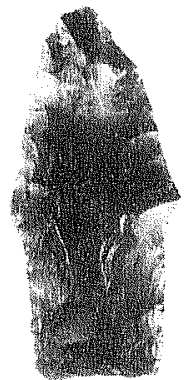

n

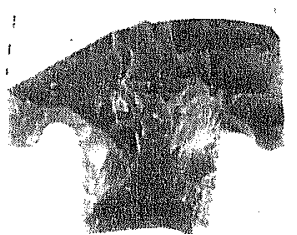

0

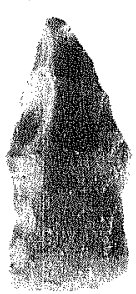

$p$

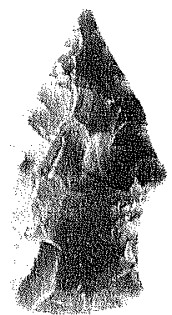

q

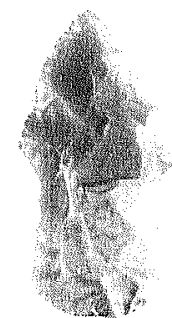

$r$

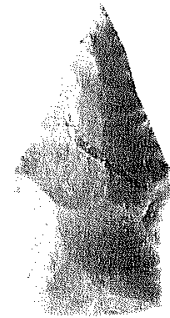

S

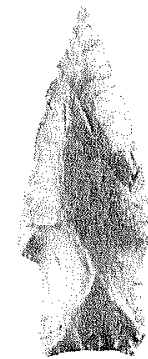

$t$

Figure 20. Dart Points, Group 3, Forms 1-5. a-f, D3:1, Pedernales; $g-i$, $D 3: 2$, Langtry; $j-1, D 3: 3 ; m-0, D 3: 4$, Bulverde; $p-t, D 3: 5$ 。 
Which are often found in east Texas, was noted by Suhm and Je1ks (1962:197, 205), who suggest that, while the two types are similar and may occur at a similar time period, a "historical connecting 1 ink" (ibid.) does not occur as an established type in central Texas. Nun ley (1971:56) has criticized the distinction between Langtry and Gary points.

Chronological Placement: Langtry points are considered by most researchers as Middle Archaic (Round Rock phase) artifacts (Johnson 1964:97; Johnson. Suhm, and Tunne 11 1962:123). Word (1970:99-102) suggests that Langtry variants were used in the lower Pecos River area over a longer time span. The Langtry points from $41 \mathrm{BX} 228$ most closely resemb le the variants Word dates to his Period 4 (2500-1000 $\left.B_{0} C_{0}\right)$. Johnson (1964:101, 1967:37) suggests that Langtry and Shumla points in the lower Pecos River area were coeval with Pedernales points in central Texas. Langtry and Pedernales points have been found in association at the Wunderlich site in south-central Texas (Johnson, Suhm, and Tunnel1 1962:45). Local Period 7.

Coding Sequence Numbers: 219-224, 226-230, and 233 .

Uncoded Lot Numbers: 249,293 , and 380.

D3:3. Form 3 - Unnamed (5 specimens; Fig, $20, j-1$ )

Description: Same as Langtry (D3:2) with the following exceptions: (1) slightly convex blade edges on some specimens; (2) distinctly convex bases; and ( 3 ) somewhat cruder workmanship.

Comments: Group 3, Form 3 dart points are somewhat problematic, because they are similar to Langtry, Gary, and Shum 1 a points. No type name is given due to this uncertainty. These points resemble Specimen F called Langtry by Johnson, Suhm, and Tunnel1 (1962:Fig. 6). The stems do not contract as marked 1 y as the Gary points 171 ustrated by Suhm and Jelks (1962:P 1 ate 99). This group also resembles Johnson's (1964:43) Shumla Variety III, although most D3:3 specimens are somewhat longer.

Chronological Placement: Local Period 7.

Coding Sequence Numbers: $232,234-237$.

D3:4. Form 4 - Butverde (24 specimens; Fig. 20,m-o)

Description: Triangular blades with convex to straight edges. Prominent shoulders usually form smal1 barbs or are occasionally squared off. Stems are parallel or occasionaliy slightly contracting. All stems have a characteristic wedge shape formed by the basal thinning of one or both faces. Stem edges are carefully trimmed. Bases are straight to convex. Workmanship is good to excellent. Heat treatment is present. Blades are frequently reworked either by beveling or bifacial trimming of an impact-fractured distal end. 
Comments: Bulverde points are recognized by the stem attributes: parallel sides, wedge-shaped longitudinal cross section created by basal thinning, and careful trimming of 1 ateral stem edges. Considerable variation occurs, resulting in various authors describing up to six variations of Bulverde-like points, (for an example, see Sorrow, Shafer, and Ross 1967:74). Suhm and Jelks (1962:169) note that concave-based Bulverde specimens approach Pedernales points. Stem characteristics of Bulverde points are similar to Bel1 points. Hence, Bell points with broken or reworked barbs may be misclassified. Group 3, Form 5 dart points may be reworked Bulverde points.

Chronological Placement: Bulverde points have been considered diagnostic of both the Clear Fork phase (Local Period 6) and the Round Rock phase (Local Period 7) by various authors. At Stillhouse Hollow, Bulverde points occur with Travis and Nol an and are hypothetically dated at 3500-2000 B.C. (Sorrow, Shafer, and Ross 1967). Prewitt ( $n_{0} d_{e}$ ) attributes Bu lverde to the Round Rock phase along with Pedernales points. At Canyon Reservoir, Bulverde points were found in both Early (Clear Fork phase) and Middle (Round Rock phase) Archaic contexts. Gerstle, Kel1y, and Assad (1978:65) assign Bulverde points to the Early Archaic (Clear Fork phase). Perhaps Bulverde points are comparatively long 1 ived.

Coding Sequence Numbers: 241, 242, 244-250, 252-260, 521, and 523 .

Uncoded Lot Numbers: $83,142,188$, and 394.

D3:5. Form 5 astubby" (5 specimens: Fig. 20, p-t)

Description: Blade outlines are triangular, with straight to convex to recurved edges. Blades are extremely small, usual 1y beveled, and a 7 was reworked. Shoulders are small but distinct. forming a point. Stems are wide in comparison to blade and always slightly expanded. Basal thinning forms a wedge-shaped stem similar to Bulverde, although not as well worked. Bases are slightly convex except one, which is slightly concave. Workmanship is good to fair, but the extremely small size and reworking of the blade gives a relatively thick appearance.

Comments: This group is not intended as a new type. They most closely resemble reworked Bulverde points. which they may be, but the uniformity in morphology and vertical distribution at $41 \mathrm{BX} 228$ distinguished this group. Shafer (1963:Fig。6,C,D) illustrates two nearly identical points. Assad and Potter (1979:Fig. 10, C) illustrate a similar point.

Chronological Placement: A11 specimens from $41 \mathrm{BX} 228$ were found in comparatively early contexts. Three specimens ( $F$ ig. 20,p,s,t) were found almost side by side in apparent Local Period 6 context at the bottom of Midden 2 in Area $M$. The two similar specimens at Youngsport (Shafer 1963) were found in a distinct zone below Travis and Nollan and above Gower. At $41 \mathrm{LL}$ 254, Assad and Potter (1979) found a similar point with Bulverde points above Nolan points. The chronological placement is somewhat confused, but it is a relatively early point form which can probably be attributed to Local Period 6. 
Coding Sequence Numbers: $374-378$.

D3:6. Form 6 - Travis (17 specimens; Fig. 21,a-d)

Description: Blade outlines are narrow triangular to leaf shaped; blade edges are convex to straight. B 7 ade edges are occasional 1 y beveled and sometimes form a point. Shoulders are usually very slight; occasionally they are distinct but are always rounded. Stems are parallel to slightly expanding or contracting. Bases are straight to slightly concave or convex. Heat treatment is possible on several specimens. Workmanship is generally somewhat crude. Most Travis points are relatively thick.

Comments: The Travis type is poorly defined. All attributes are variable, and the type grades into many others, as Suhm and Jelks (1962:251) note.

Chronological Placement: See Nolan point (D3:7) chronological placement. Travis and Nolan dart points are the time markers of Local Period 6.

Coding Sequence Numbers: 355-371.

\section{D3:7. Form 7 - Nolan (54 specimens; Fig. $21, e-h$ )}

Description: Blades have outlines varying from narrowing triangular to 1 anceolate; blade edges are usually convex, occasionally straight, rarely concave. Shoulders vary from weak to moderately developed; they are usually rounded but may be almost squared offo Stems expand slightly to markediy; stem edges are usually steeply beveled on alternate edges, most often on the left edge. Bases are usually convex, occasionally straight, and rarely concave. Workmanship varies from poor to good. Heat treatment is common. Blade edges are occasionally beveled.

Comments: Nolan points are characterized by the steep alternate beveling of the stems; however, degree of beveling varies on some Nolan points. Some specimens have beveling on both edges of one face; others have on $7 y$ slight beveling.

Chronological Placement: Nolan points, along with Travis points, are the period markers for Local Period 6 (Weir 1976a).

Coding Sequence Numbers: 225, 285-324, 554, 555, and 561.

Uncoded Lot Numbers: C9, 48, 152, 341, 361, 380, 387 (two specimens), and 467.

D3:8. Form 8 - La Jita ( 6 specimens; Fig. $21, i-1$ )

Description: Blade outlines are narrow triangular, with convex to straight blade edges. Shoulders are slight and rounded. Stems expand and are rounded and may have beveling on one or both edges but lack the steep beveling of 


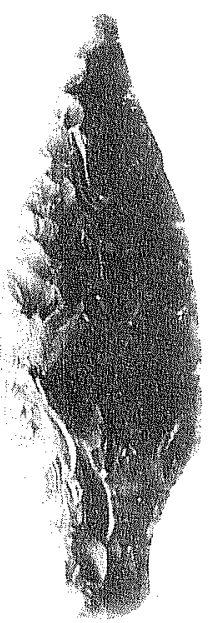

a

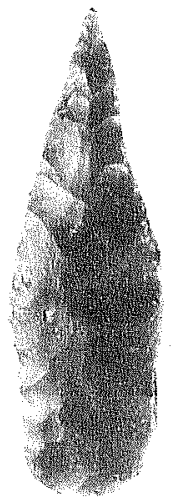

b

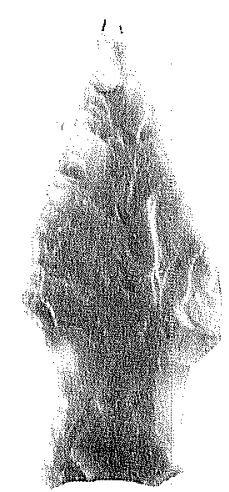

C

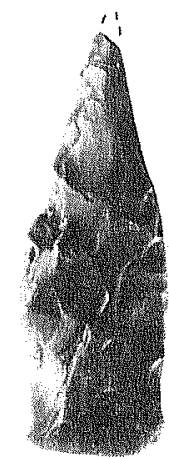

d

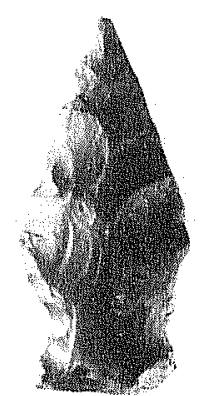

e

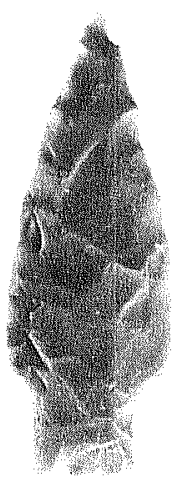

$f$

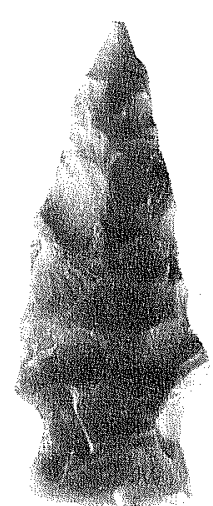

9

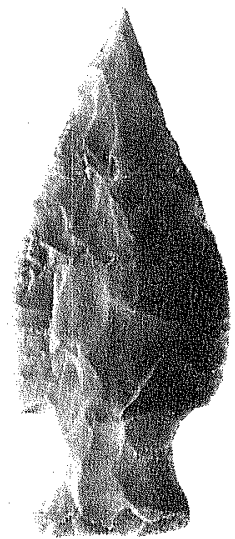

h
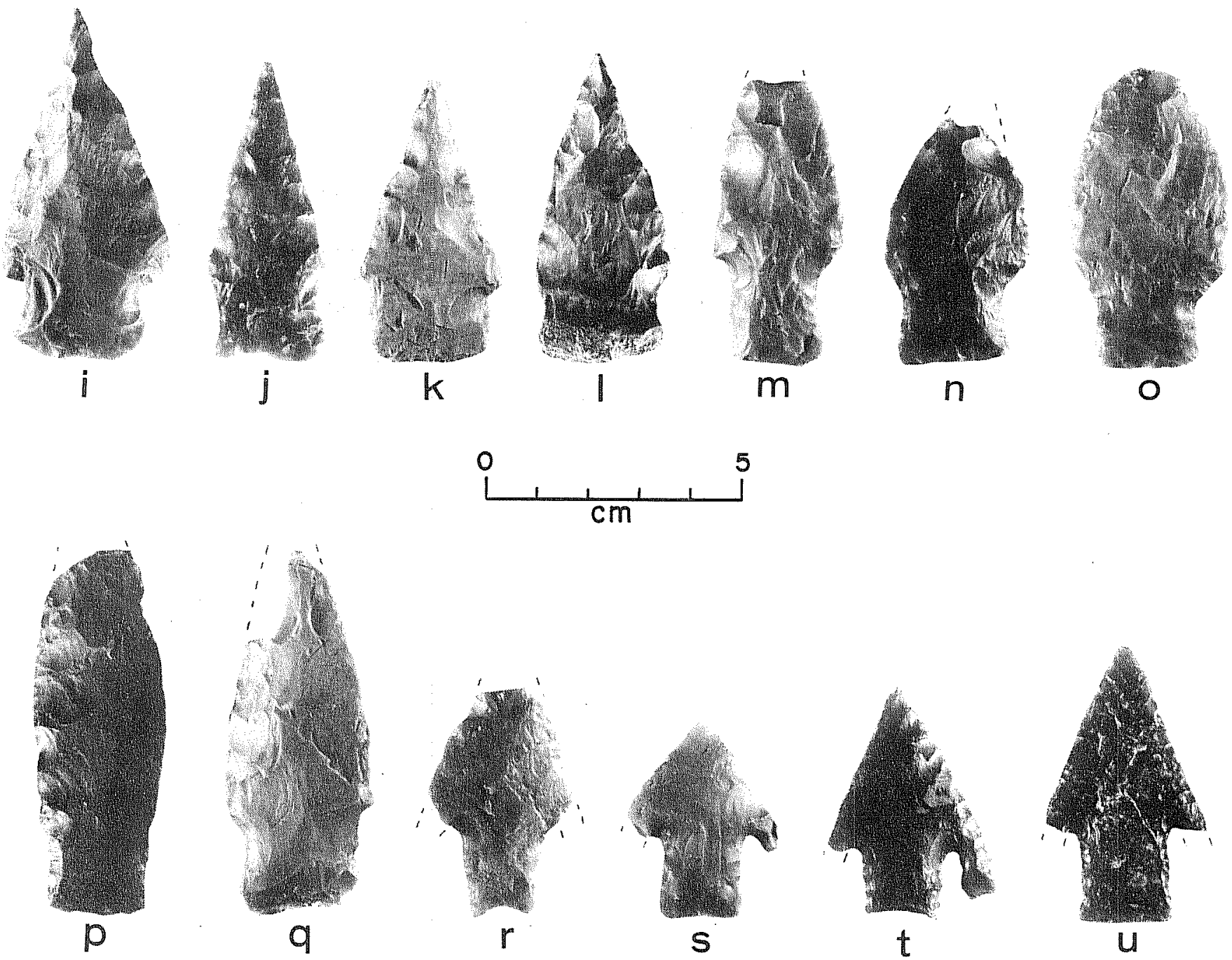

Figure 21. Dart Points, Group 3, Forms 6-11. a-d, D3:6, Travis; e-h, D3:7, Nolan; $j-1, D 3: 8$, La Jita; $m, n, D 3: 9 ; p, q, D 3: 10$, Pandale; $-u, D 3: 11$, Bel1. 
Nolan points. Bases are straight to slightly convex or concave. Patination occurs on most specimens. Workmanship is crude to fair.

Comments: Hester (1971:74) proposed La Jita as a tentative type; they have since been found at other south-central Texas sites. The most distinctive attribute is the expanding rounded stem. Hester (ibid.) and Gestle, Kelly, and Assad (1978) note alternate beveling on many La Jita points. The 41 BX 228 specimens are not alternately beveled. This type seems to grade into Molan points. Hester (personal communication) has recently suggested that the La Jita type may be unfinished Nolan points. Carrol 1 (1983) has recently described a "new dart point type, the Medina point, that appears very similar if not identical to the La Jita type.

Chronological Placement: La Jita points from the type site (Hester 1971:118119) were found in mixed Round Rock and Clear Fork contexts. At 41 KE 49 (Kelly and Hester 1976), La Jita points were found with Clear Fork phase points.

Chronological 1 lacement is questionable, but as Nolan points are usually found in the same context, it is suggested that they are contemporaneous. Local Period 6.

Coding Sequence Numbers: $379-384$.

D3:9. Form 9 - Unnamed ( 9 specimens; Fig. $21, m, n$ )

Description: Triangular to leaf-shaped blades are usually rather broad and long; blade edges are convex. Shoulders are distinct but never barbed. Stems expand slightly. Bases are straight to 51 ightly convex or concave. Stem beveling frequently occurs on one edge only or on both edges of one face. Workmanship is rather crude to good.

Comments: Group 3, Form 9 dart points resemble Nolan points but 1 ack alternate stem beveling; in addition, they resemble Travis points, but do not have beveled blades. The occurrence of similar points which share attributes of Nolan, Travis, and Pandale points is well documented. Kelly (1961:254, Fig. 8,H-J) illustrates similar points which he termed "Trolan." Weir (1979:31) terms similar unifacially beveled stem points Zorra; however, Weir's Zorra points differ somewhat from Johnson's $(1964: 45)$ original definition of Zorra points.

Chronological Placement: While the typology may be confused, this form seems to be clearly associated in time and space with the types it resembles. Local Period 6.

Coding Sequence Numbers: 500-505 and 507-509. 
D3:10. Form 10 - Pandale (3 specimens; Fig. $21, p, q$ )

Description: Narrow leaf-shaped blades with convex edges. Blades have a distinct twisted appearance due to beveling of the blade on alternate faces. The beveling actualiy extends to the longitudinal axis. Shoulders are slight and rounded. Stems slightiy expand and are more or less beveled on opposite sides of the blade edge. Bases are slightly convex to straight.

Comments: This form is quite common in the lower Pecos River region but rare in central Texas. Pandale points are similar in outline to Nolan and Travis points and are probably contemporaneous. The unique twisted blade is not actually beveled in the usual sense of the word, as Word $(1970: 33)$ notes.

Chronological Placement: Word (1970) places Pandale with Nolan in Period 3 (4000-2500 B.C.) at Baker Cave. At Devil's Mouth (Johnson 1964), Pandale points were found stratigraphically between "Early Barbed" and Langtry. Local Period 6.

\section{D3:11. Form 11 - Be11 (5 specimens; Fig. 21,r-u)}

Description: Blade outlines are triangular with straight to slightly convex edges. Very prominent shoulders with long barbs formed by narrow basal notches cut in deeply from the base. The stems are straight to very slightly expanding or contracting. Bases are straight or concave. Workmanship is excel lent. Some specimens appear heat treated.

Comments: Bell points are distinguished by their deep basal notches. The barbs formed by the notching are comparatively long and wide. Many Be11 points have the barbs broken and are often reworked, resemb 1 ing Bulverde points ( $F i g, 21,5, U$ ). The deep notching leaves an unusual $U$-shaped flake scar at the top of the notch which can usually be observed on specimens with broken barbs. Bell points were obviously made from triangular preforms.

Chronological Placement: The Bell point has been found in Early Archaic contexts at several central Texas sites. Shafer (in Sorrow, Shafer, and Ross 1967:12) first defined Be 11 points at the Landslide site. Shafer placed Bel1 points and Untyped III, a triangular form similar to Group 6, Form 3, in Still house Hol low Phase IV, which dated to approximately 4500-3500 B.C. Weir (1976a:124) states that Be11 points occur later than Gower, Uvalde, and Martindale in the Early Archaic. At 41 BX 271, the Granberg II site, a radiocarbon date of 3600-3400 B.C. (MASCA calibration) was associated with Be11. Bell points have been found in several additional sites in stratigraphic contexts which clearly suggest they appear prior to the Clear Fork phase (cf. Hester 1979b). Local Period 5.

Coding Sequence Numbers: 238-240, and 251 .

Uncoded Lot Numbers: 350. 
D4. Group 4 - Early Expanding Stem (30 specimens)

Considerable controversy has arisen over the projectile point typology and the regional naming of Local Period 5 (Early Archaic/Pre-Archaic/San Geronimo phase/Jarre 17 and Oaka1 1a phases) in central and southern Texas (cf. Hester 1979b). There is 1 ittle doubt that a variety of expanding stem dart points occur in Early Holocene contexts between approximately 6000-3000 B.C. over a wide area of Texas from at least far north-central Texas to the lower Pecos River area to south-central Texas. Similar point styles occur at about the same period across much of North America (Sol 1 berger and Hester 1972:338340). These expanding stem points have been given various type names in Texas, including Bandy. Baker, and Early Barbed (Word 1970); Early Corner Notched (Hester 1971): Martindale and Uvalde (Weir 1976a): and possib7y Early Side Notched (Gerstle, Kel1y, and Assad 1978). These groups are not mutually exclusive. For an excellent discussion of this confusion, see Hester (1979b). Hester (Ibido:5, and personal communication) believes that many of these points do not neatly fit into defined types but rather form a continuum of points which "grade from one extreme to the other."

At 41 BX 228 a number of early expanding stem projectile points were excavated in clear Local Period 5 contexts. Hester's observation seems to most accurately describe the 41 BX 228 points--they form a continuum of variations on the theme of expanding stems. They are referred to herein as "early expanding stem" points because they a 11 come from comparatively early contexts, and they a 17 have expanding stems. Rather than describing 30 miscellaneous forms, the early expanding stem points have been sorted into three forms that appear to be mutually distinctive.

D4:1. Form 1 - Unnamed (14 specimens: Fig. 22,a-f)

Description: Broad triangular blades are most common, but short triangular with reworked blades (Fig. 22, a, C) are also present. S1ightly irregular collateral parallel flaking gives some blades a slight serration (Fig. $22, f$ ). Blade edges are usually slightly convex, but occasionally may be straight or recurved (Fig. 22,b,d). Prominent shoulders are always barbed. Barbs are formed by corner notches. Barbs are usually short and never reach the base. Stems are short and markedly expanded. Bases are shallow concave, with some slight ly recurved. Workmanship is always good to excellent, except on reworked specimens. Several specimens appear heat treated.

Comments: Group 4, Form 1 dart points do not fit into any previously described type. Similar specimens include those illustrated by Sorrow. Shafer, and Ross (1967:Fig. 14, C); Wesolowsky, Hester, and Brown (1976:Fig. $15, \mathrm{~d})$; and Hester (1971:Fig. 10, h). This group is similar to Martindale points except that they do not have the distinctive recurved "fishtail" base.

Chronological Placement: Local Period 5.

Coding Sequence Numbers: $438-440,444-449,455-458$, and 464 .

Uncoded Lot Number: 345. 


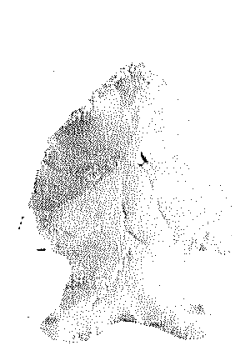

a
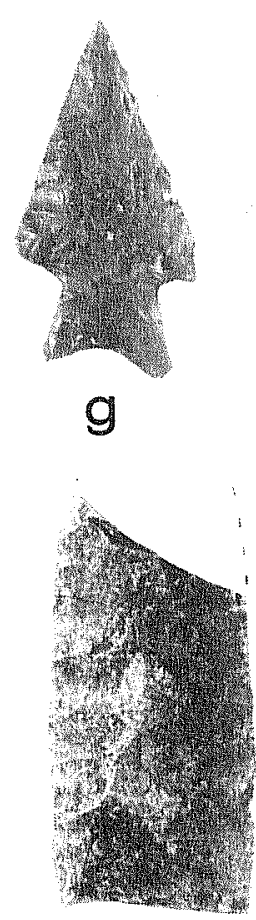

$\mathrm{m}$

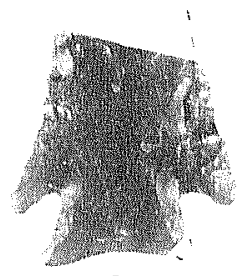

b

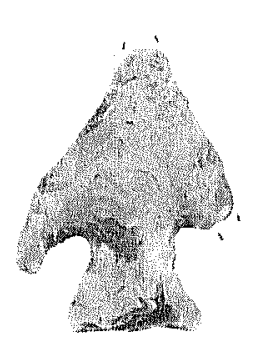

C

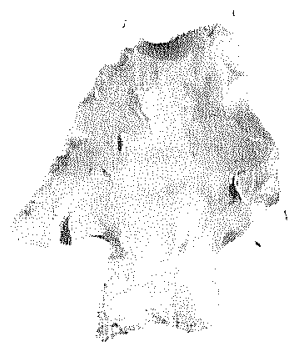

d
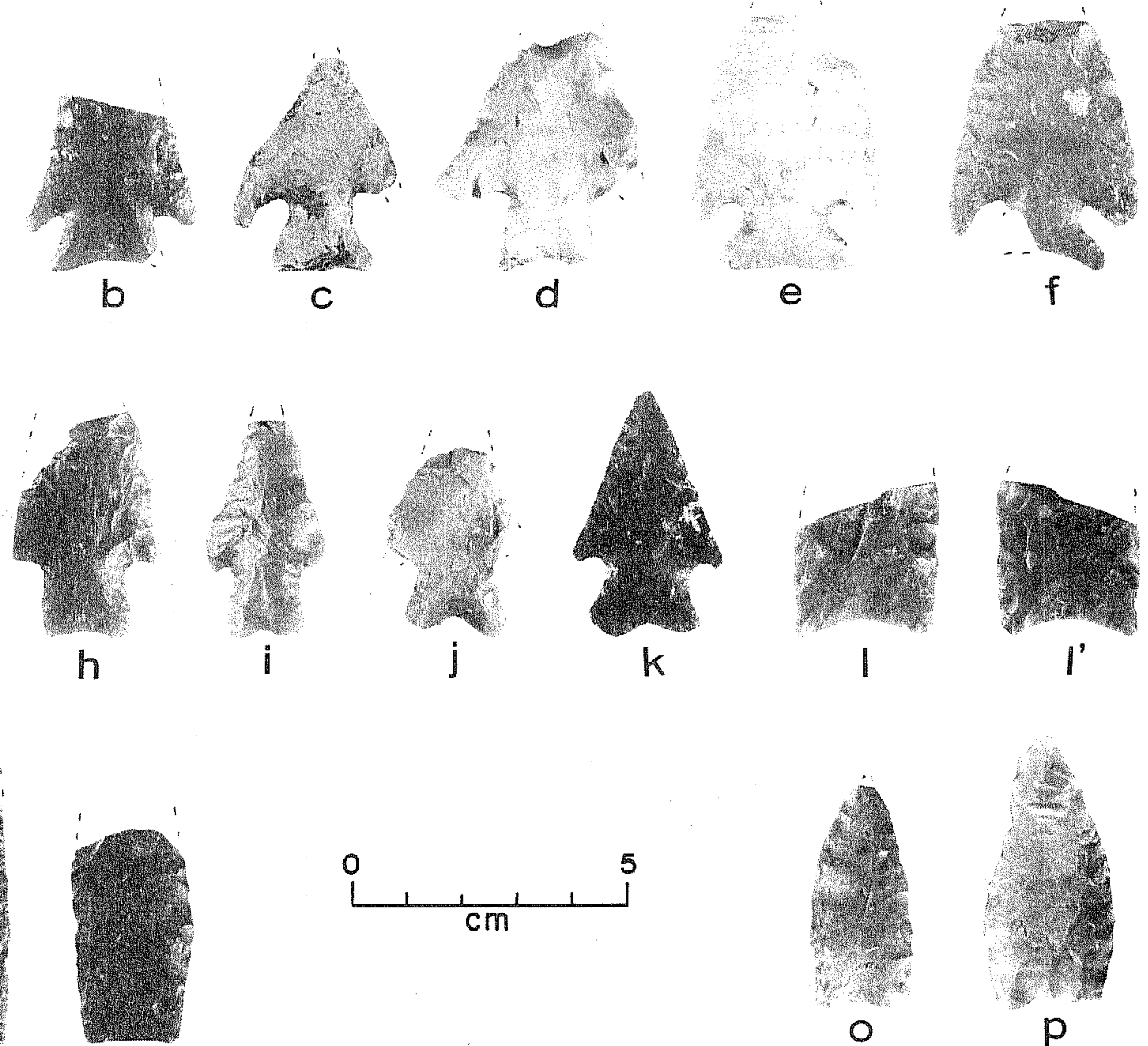

n
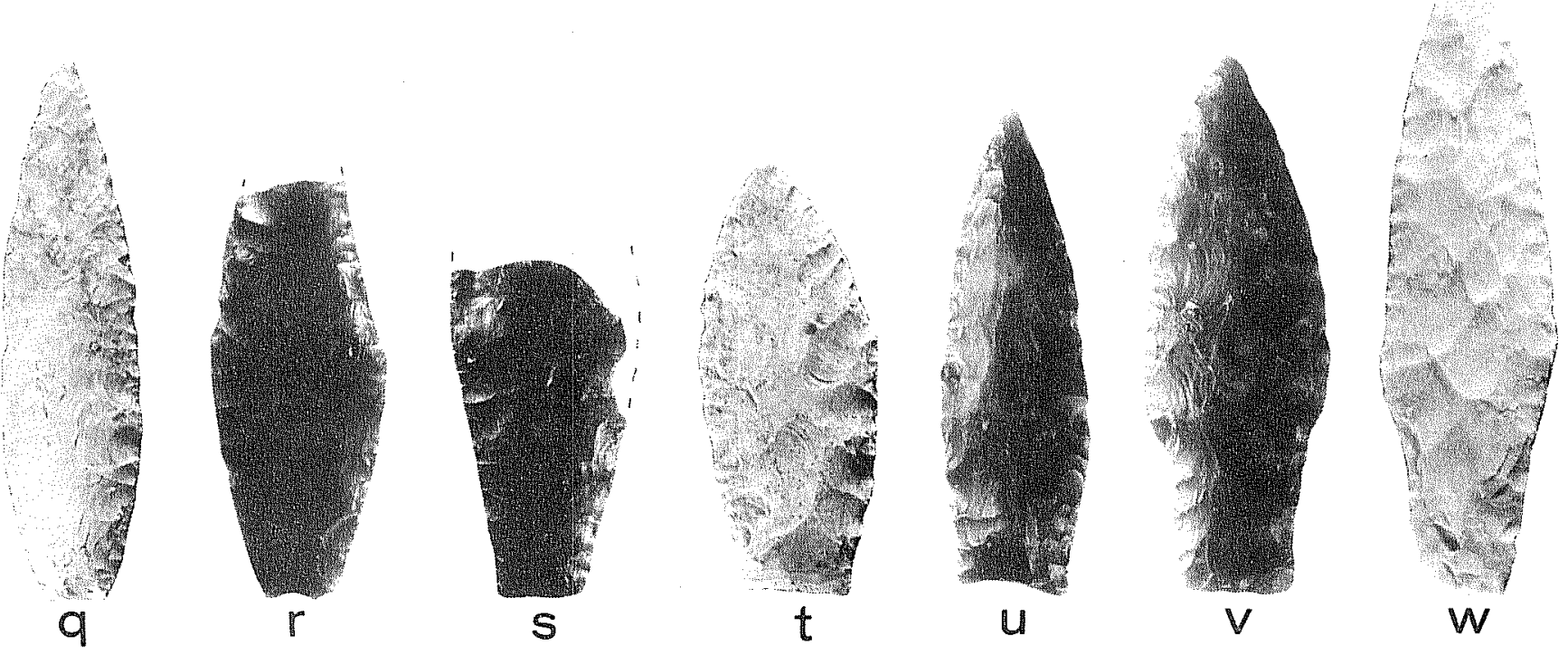

Figure 22. Dart Points, Groups 4 and 5. a-f, D4:1; g-i, D4:2; j,k, D4:3, Martindale; $m, n, D 5: 2 ; 0, D 5: 3 ; p, D 5: 2 ; q-s, D 5: 1$, Angostura; $t-w, D 5: 3$. 


\section{D4:2. Form 2 - Unnamed (9 specimens; Fig. 22,g-i)}

Description: Triangular blades; most are narrow triangular and some almost parallel sided (Fig. 22,h). Blade edges are straight to convex to concave. Shoulders are distinct and usually squared off or occasionally slightly downturned. Barbs are either very smal1 or not present. Stems expand but not widely. Bases are shallow concave. A wide, shallow notch angled from the corner or base forms the slightly expanding stem. Workmanship is fair to good. Several points have been reworked. Heat treatment is present on several specimens.

Comments: As a group, $04: 2$ points are smal1er, have 1 onger and narrower stems, and 1 ack the distinctive barbs of $D 4: 1$. These points fit Hester's (1971:73) Early Corner Notched Variety 2 reasonably we 11, especially Figure 10,n-s; they are also similar to Figure 10,v, which Hester terms Edgewood. Weir (1976a:Fig。9,D) 117ustrates a similar point which he terms Uvalde; however, Uvalde points as per the original definition (Suhm and Jelks 1962:255) have a "deep U-shaped concavity" which the 117 ustrated specimen and D4:2 clearly do not have. To the best of the author's knowledge, no one has redefined the Uvalde type; it remains a broadly defined type which serves little purpose. Kel1y (1961:Fig. $8, N, P, R)$ illustrates similar points he referred to as "unidentified concave base."

Chronological Placement: Local Period 5.

Coded Sequence Numbers: 451, 453, 459, 460, 462-464, and 557.

Uncoded Lot Number: 427.

D4:3. Form 3 - Martindale ( 7 specimens; Fig. $22, j, k$ )

Description: Triangular blades; blade edges are straight to convex. Shoulders are prominent. Corner notches form short barbs. Stems expand marked 1 y. Bases are recurved giving the point its distinctive "fishtail" appearance. Workmanship is fair to good.

Comments: Group 4, Form 3 specimens are similar to $D 4: 1$, but they have the distinct base which conforms closely to Suhm and Jelks (1962:213) type definition. Similar specimens include those illustrated by Gerstle, Kelly, and Assad (1978:Fig. 19,f-h,j,k), Hester (1971:Fig. 10,i-k, termed Early Corner Notched Variety 1), and Weir (1976a:Fig.9,F,G). Hester (1979a:5) objects to the use of the Martindale type as temporally defined by Suhm and Jelks (1962); however, D4:3 points do closely fit the type definition, and no one has conclusively associated Martindale points with 1 ater phases or periods to this author's knowledge.

Chronological Placement: Local Period 5. In view of the above cited references which conclusively associate Martindale points within the Early Archaic, the type definition presented in Suhm and Jelks (1962:213) should be modified to include the correct chronological placement. 
Coding Sequence Numbers: $441=443,450,452$, and 556.

Uncoded Lot Numbers: 344 and 371.

D5. Group 5 - Lanceolate/Leaf Shaped (13 specimens)

Group 5 dart points include a number of 1 anceolate to leaf-shaped thin bifaces, most of which share similarities with Paleo-Indian projectile points. No evidence of an intact Paleo-Indian component was found at $41 \mathrm{BX} 228$, although several of the Group 5 specimens were found in the lowest levels of occupation. Many central Texas sites contain small quantities of Angostura points, which Weir (1976a:115) says "seem to be out of place." The fact that most of the Angostura points found at 41 BX 228 are reworked and occur in contexts much 1 ater in time than the Late Paleo-Indian period supports Weir's (ibid.) observation.

Group 5 points are described in three forms, a 1 though most specimens are distinct enough to merit individual description.

D5:1. Form 1 - Angostura (3 specimens)

Description: Blade outlines are narrow leaf shaped or lanceolate; maximum width and thickness usually occur near the midpoint or distal half of point. Shoulders are absent. The base is narrow and slightly concave or straight. Lower one-third or one-half of blade edges (stem) are smoothed. Workmanship is exceptiona 1; col1ateral paral1e1 flaking is present on a 11 specimens. Each specimen is identified by a coding sequence number.

547 (Fig. 22,r): Heavily smoothed; upper b1ade is reworked; fire fractured.

548 (Fig. 22,s): Heavily smoothed; impact fractured; fracture shows possible use-wear: heavily burned.

549 (Fig. 22,q): Very light smoothing: complete, heavily patinated. Similar specimens are called Angostura-Plainview (Alexander 1963:Fig. 2,a).

Comments: The Angostura type definitions are often inconsistent. See Alexander (1963:513) for a discussion. D5:l specimens fit Suhm and Jelks (1962:167) type definition.

Chronological Placement: The Angostura point is clearly a Late Paleo-Indian type, although central Texas sites with Angostura components are very rare. Levi Rockshelter (Alexander 1963) is one of the few. Weir (1976a) attributes Angostura to the Early Archaic. However, it is not clear whether these points were actually being made during the Early Archaic or were "curated" specimens. Two of the three 41 BX 228 specimens were found in clearly 1 ater contexts: both are fire fractured and reworked or show use-wear on a broken edge. The other specimen was found in backdirt from Area $M$ in transition zone soil. 
Recent excavations at the Wilson-Leonard site in Williamson County have uncovered dozens of Angostura points along with other lanceolate and stemmed points in wel1-stratified contexts (Bob Stiba, personal communication). The analysis of the Wilson-Leonard site by Texas Department of Highways and Public Transportation personnel should provide a much clearer understanding of the chronological position of Angostura points.

\section{D5:2. Form 2 - "Longitudinally Thinned" (4 specimens)}

Description: Form 2 specimens vary in many important attributes, but a 11 have some degree of basal thinning by longitudinal flaking. Each specimen is identified by a coding sequence number and are described individualiy.

545 (Fig. 22,p): The smal1 1 anceolate impact-fractured b 1 ade has been reworked by beveling on one face. The base is slightly concave. On one face a small longitudinal thinning flake has been removed; on the opposite face two smal1 longitudinal flakes have been removed. The artifact is made of gray chert with tan impurities which caused step fractures along one edge.

562 (Fig. 22,m): This specimen has a large lanceolate blade and is missing one-fourth or less of the distal end. Blade edges are parallel and very slightly convex. The specimen is heavily burned and patinated. Both faces have indications that a longitudinal flake or "flute" has been removed. Additional basal and edge trimming occurred after "flutes" were removed. A basal "nipple" is present which suggests that the base was being prepared for removal of another flake. Base and lower stem edges are slightly smoothed. This point strongly resembles Clovis points in size, shape, and flaking. It was found in the "sterile" gravels underlying the cultural deposits. The point shows no indication of stream transport. Severe burning unfortunately obscures some of the details, hence, identification is inconclusive. Curtis Tunnel1 (personal communication) examined this specimen and suggested that it is morphological1y consistent with Early Paleo-Indian projectile points.

563 (Fig. 22,n): Lanceolate basal fragment. The blade expands from the base. The blade edges are slightly beveled. It has been fire fractured. The base is straight and smoothed. An irregular longitudinal thinning flake extends $2.7 \mathrm{~cm}$ from the base on one face. A smal1er scar is present on the opposite face. Flaking is not particularly good.

564 (Fig. 22, 1, 1\%): Lanceolate basal fragment. Paral1e1 blade edges are lightly smoothed. It has a concave base. One face has a distinct longitudinal thinning flake; the opposite face has two flakes. This point has a distinct "fluted" appearance. The chert is a mottled brown and gray with a grainy inclusion at the break. This point was found in situ in Area $M$ along with the 545 specimen (Fig. 22,p) and a variety of Local Period 5 diagnostics. Several experienced colleagues expressed the opinion that this point bears strong resemblance to the Clovis type and would not, except for the fresh unpatinated 1ook, appear out of place in Early Paleo-Indian contexts. Similar longitudinal thinning occurs on triangular specimens $(D 6: 3)$ found in the same zone. 
D5:3. Form 3 - "Miscellaneous Lanceolate to Leaf-Shaped" (6 specimens)

Group 5, Form 3 dart points vary widely and merit individual description. Each specimen is identified by a coding sequence number or lot number (number 438).

543 (Fig. 22,0): Smal1 1 anceolate, complete. F Taking is col1ateral and paral 1e1, but is somewhat irregular. Base is slightly concave and has been thinned with smali U-shaped flakes. The chert is brown and pink banded and is probably heat treated.

352 (Fig. 22,v): Large, Teaf-shaped point, Blade edges are convex. A faint shoulder is present about one-third of the length from the base. Stem and base are heavily smoothed; one edge of the stem is beveled. The base is straight. This point is somewhat thick. Shape and stem smoothing suggest Angostura, but it lacks flaking characteristics of that type.

353 (Fig. 22,u): Narrow, leaf-shaped point. Blade edges are convex. There is no discernible shoulder, but the lower portion of the stem 51 ightly flares at the base. The base is convex. This specimen is relatively thick on one face, giving much of the point a beveled appearance. Blade edges are slightly serrated.

354 (Fig. 22,w): Large, narrow, leaf-shaped point. Blade edges are convex. Faint shoulders are present. The stem tapers to the base, and stem edges are almost straight. The base is very slightly convex and narrow. The material is a patinated gray chert. Workmanship is excellent.

565 (Fig. 22,t): Leaf-shaped point, s1 ightly asymmetrical. Convex b 1 ade edges converge toward base. Faint shoulders are present above the midpoint. The base is straight. The point is heavily patinated and somewhat thick. It is probably unfinished, but the outline resembles an Angostura point.

438 (not illustrated): Midsection of a 1 anceolate point. Collateral parallel flaking is present on both faces. It is made of a gray chert which is possibly heat treated.

\section{D6. Group 6 - Unstemmed Triangular (31 specimens)}

Group 6 includes three thin triangular biface forms which are commonly referred to as projectile points. This author believes all of these artifacts probably functioned primarily as knives, rather than as projectile points. They are reluctantly included within the projectile point category for comparative purposes, as most regional archaeological reports describe them as such. Fiscal limitations precluded the detailed microwear studies and replicative experiments necessary to substantiate the interpretation that most Form 3 specimens functioned as knives.

The reasons that led this author to bel ieve that most triangular forms functioned as knives are as follows: (1) unstemmed triangular forms always occur with stemmed forms (dart points); (2) the unstemmed triangular forms 
are almost always unbroken and lack impact fractures, while the stemmed forms have a very high breakage frequency and a relatively high frequency of impact fractures; (3) the unstemmed triangular forms have a very high frequency of b lade edge resharpening by beveling and bifacial resharpening: (4) some unstemmed triangular specimens lacking fresh resharpening appear very heavily worn or dulled from apparent use-wear: and (5) possible use-polish remnants are present on the biade faces.

\section{D6:1. Form 1 - Kinney ( 6 specimens; Fig, 23,a-d)}

Description: Triangular blades with convex edges; one specimen has slight alternate beveling on the left blade edges. No shoulders or stems are present, although the lower blade portion is usually parallel or contracts slightly. The base is always strongly concave, either by a single broad arc or slightly recurved. Workmanship is good to excellent. Several specimens appear heat treated.

Comments: Group 6, Form 1 dart points fit the type description of Suhm and Jelks (1962:210), who note that larger asymmetrical specimens are probably knives. The 41 BX 228 specimens are all approximately the same size and are consistently symmetrical, except for one specimen which may be unfinished. Kinney points or knives are a minor type that occurs most often from the south central to the central coast to the lower Pecos River region of Texas.

Chronological Placement: Somewhat unclear. Weir (1976a:Fig. 13) illustrates Kinney points as Twin Sisters phase artifacts, yet Weir and Doran (1980:18) state that Kinney points are associated with the Round Rock phase. At the Wunderlich site (Johnson, Suhm, and Tunnel1 1962), a single Kinney specimen was found associated with Local Periods 6 and 7 artifacts. At the La Jita site (Hester 1971), Kinney points were found in Loca 1 Period 7 contexts. A Local Period 7 placement seems most 7 ikely.

D6:2. Form 2 - Carrizo (1 specimen; Fig. 23,e)

Description: Triangular blade with straight edges. Unstemmed convex base with a rounded $V$-shaped notch cut into the center. Excellent workmanship, very thin.

Comments: Carrizo points occur mainly in southwest Texas in the Dimmit, Zavala, and Real Counties area. The type was first described by House and Hester (1967), who noted their rather isolated distribution. It is possible that the 41 BX 228 specimen is a Montel 1 preform; however, in most cases the two types do not co-occur (T. R. Hester, personal communication). If the Carrizo point from 41 BX 228 is a Monte 11 preform, one wonders why it was not completed, as there are no material flaws, and it is unbroken.

Chronological P1acement: Unknown. The specimen from 41 BX 228 is from mixed Archaic contexts, probably Local Period 7 or earlier. Other reported specimens are from surface collections from predominant1y Archaic assemb 1 ages (House and Hester 1967). 


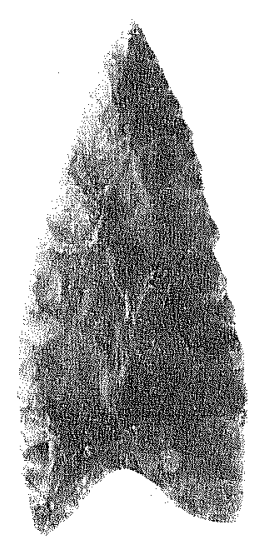

a

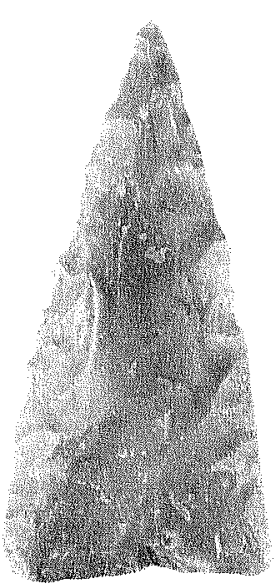

f

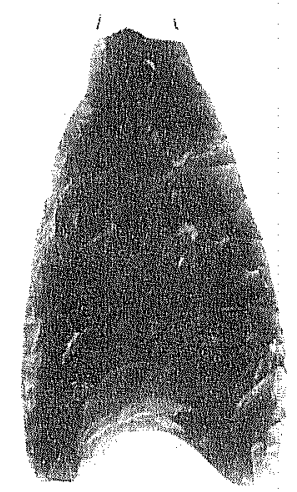

b

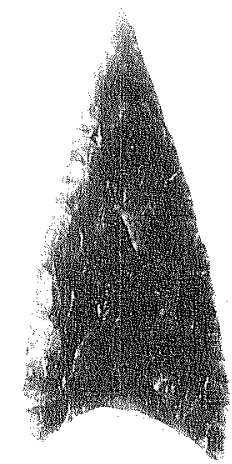

c

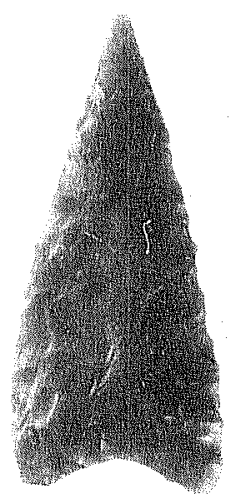

d

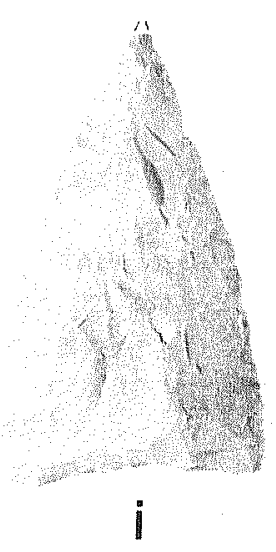

h

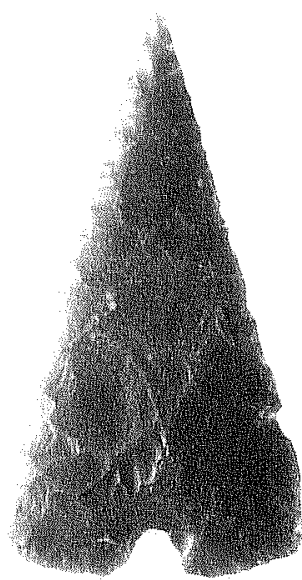

e

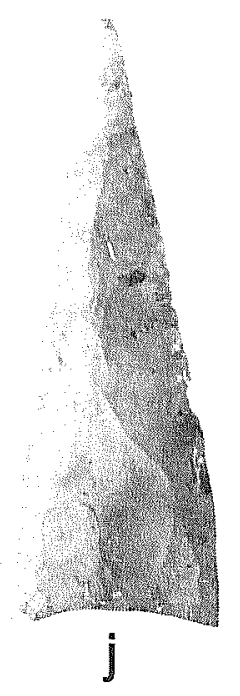

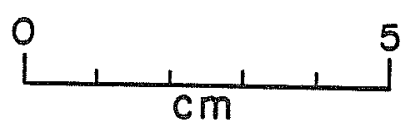

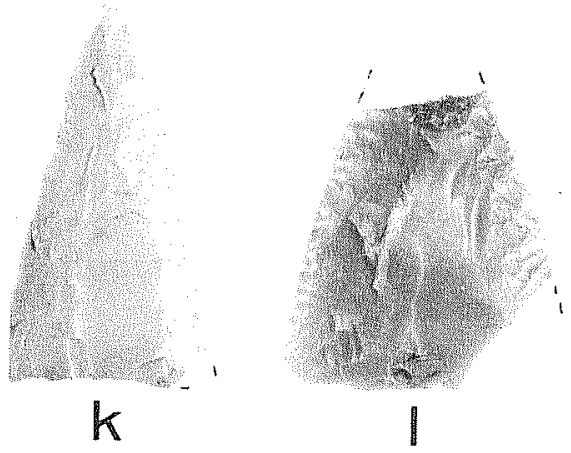

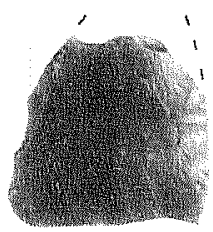

m

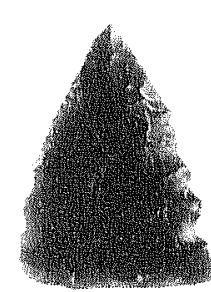

$\mathrm{n}$

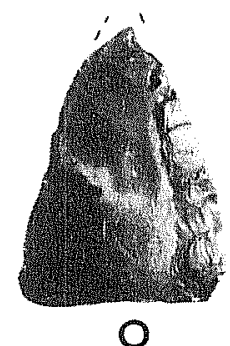

O

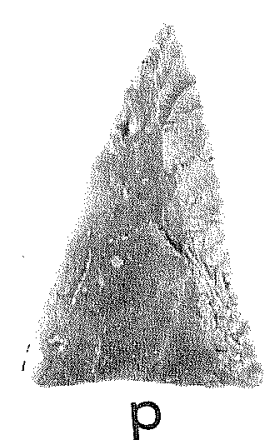

Figure 23. Dart Points (Knives?), Group 6. a-d, D6:1, Kinney; e, D6:2, Carrizo; f-p, D6:3, "Thinned-Base Early Triangular." 
Coding Sequence Number: 325.

[6:3. Form 3 - "Thinned-Base Early Triangutar" (24 specimens; Fig. 23,f-p)

Description: The triangular blade is usually narrow triangular or occasionally broad (equilateral) triangular. Blade edges are often straight or convex but rarely recurved. Blade edges vary in degree of beveling; alternate beveling is most frequent, followed by partial beveling (one edge on 1 y) on both edges of one face, or rarely unbeveled. The base is well thinned to irregularly thinned by removal of large longitudinal flakes ("flutes"), smaller longitudinal flakes, marginal edge trimming, or a combination of techniques. The base is usually slightly concave but may be straight. Distinct stems are not present, but on most specimens the 1 ower one-fourth to one-sixth of the blade edges are unbeveled, smoothed, and/or paral1el sided. Occasional specimens have slightly smoothed bases. Most specimens are symmetrical or s1ightly asymmetrical, but occasionally are very asymmetrical. Maximum thickness usually occurs in the midsection slightly toward the distal end. Edge angles vary considerably but most often fa 11 with in the $40-60^{\circ}$ range. Workmanship is good to exceptiona 1 ; some specimens (Fig. 23,g, 1) have parallel flaking. Form 3 specimens frequently appear heat treated. Two specimens are made from non 1 ocal yel low chert. Nonmetric attribute data is presented in Table 12.

Comments: This form has been the subject of considerable typological confusion. The following type names may be applicable to these specimens: Baird Beveled Blade and Tay Ior Thinned Base (Kel ley 1947a), Tortugas (Suhm, Krieger, and Jelks 1954), Taylor and Baird (Sorrow 1969), and Early Triangular (Hester 1971). A chronological history of this typological jumble begins in 1947. Kel ley (1947a) briefly described what he apparently felt were three discrete forms with differences in morphology and/or geographical distribution. Suhm, Krieger, and Jelks (1954) could not distinguish between the three types, so they 1 umped them together under Tortugas. Shafer (in Sorrow, Shafer, and Ross 1967) at the Landslide site and Sorrow (1969) at the John Ischy site found differences in triangular bifaces which they believed were masked by the single term Tortugas. Shafer (in Sorrow, Shafer, and Ross 1967) described an "Untyped III" group in addition to Tortugas. Sorrow (1969) found two of Kel ley"s (1947a) original types useful so he proposed that Taylor and Baird types be used. Hester (1971) noted the above confusion and used the term "Early Triangular" to describe triangular forms he found in early contexts and "Late Triangular" to describe triangular forms he found in later contexts.

The causes of the above confusion apparently stem from the overlapping geographical and chronological distribution of triangular forms and the presence or absence of blade beveling and basal thinning. It is clear that basally thinned triangular forms that are sometimes beveled occur in Early Archaic and $\mathrm{Clear}$ Fork phase contexts in south-central to north-central Texas. Triangular forms which may or may not have basal thinning and alternate beveling are very widespread in south and southwest Texas and were probably used over a longer time span. 


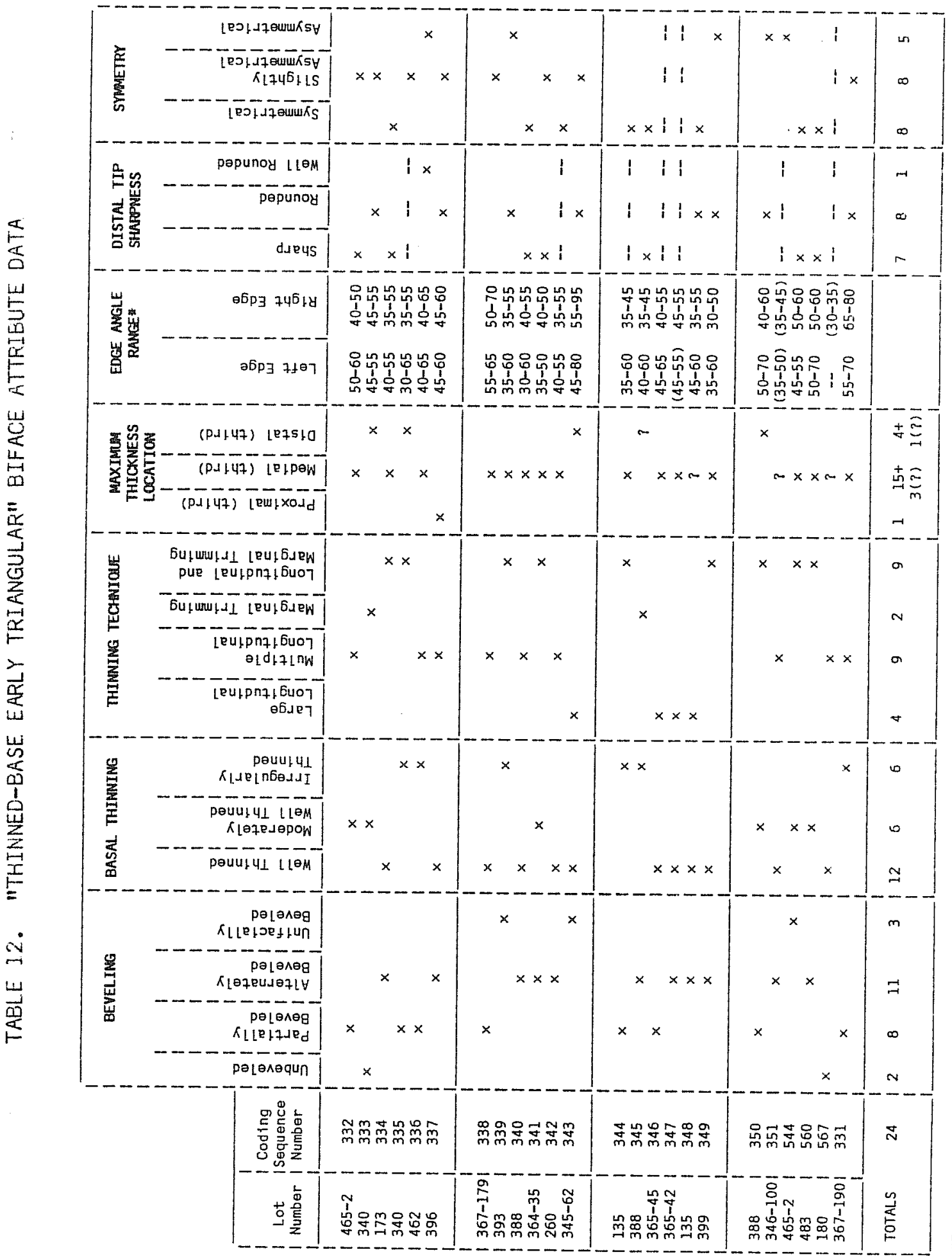


The 41 BX 228 triangular specimens that fit into these groups are clearly from the lowest occupation levels of the site, occurring with Local Periods 5 and 6 diagnostics. They are virtually absent in Local Period 7 contexts or later. Much of the confusion could be explained if these triangular "projectile points" are actually knives. All specimens have some degree of basal thinning. which probably facilitated hafting. Alternate beveling occurs most often and is most pronounced on the smalier specimens. This author believes alternate beveling is a sharpening technique which is utilized when the hafted knife becomes too small or too thick to resharpen using other bifacial resharpening techniques. Sol 1 berger (1971) discusses three types of knife resharpening techniques from a flintknapper's ferspective. He believes that edge beveling was a conservation measure used when flint was too scarce to biface. He notes that resharpening by edge beveling reduces the tool size considerably less than edge bifacing. At 41 BX 228 the availability of raw material was obviously not a factor. It is suggested that the knife, once hafted, was beveled as an attempt to maintain the sharp edge to avoid rehafting another knife.

Assuming these arguments are correct, then the typological problem is simp 1e--these are not distinct "types" but rather a continuum of triangular forms. The degree of basal thinning and flaking techniques was probably more dependent on the quality of chert and the knapper's skill than on stylistic considerations. The size and edge beveling reflects the amount of use, resharpening techniques, and the desire to maintain a hafted tool. After careful examination of Form 3 specimens, this author was unable to satisfactorily sort them into discrete types, either those previously defined or undefined. It is believed that al 1 these artifacts served a similar function, occurred during the same time span, and were products of a similar mental template, hence they are included in one form. The metric and nonmetric attribute data should be sufficient to allow others to attempt to subdivide this form into as many categories as they see fit. The term "thinned-base early triangular" is a descriptive name, not a type name.

A model of the manufacturing and resharpening sequence of the "thinned-base early triangularl biface is proposed based on artifacts recovered from $41 \mathrm{BX} 228$ (Fig. 24). The 111 ustrated portion of the sequence begins with a thin triangular biface (initial preform). The initial preform is then further thinned, and the base is beveled from one face to set up a platform for removal of basal thinning flakes (final preform). The final preform is sharpened by pressure flaking along the blade edges and basal1y thinned. Some specimens have skillfully executed parallel pressure flaking along the blade edges. Basal thinning is achieved by the removal of a single "flute" or more commonly, several smaller thinning flakes. The resulting finished tool is then hafted and used as a cutting implement, probably a butchering knife. The distal end and blade edges become heavily worn and damaged during use. The dulled tools are resharpened while hafted to avoid the time consuming job of rehafting a new tool. Resharpening is accomplished by alternate beveling, bifacial retouch, or unifacial beveling. Finally, after several resharpenirgs, the smal1 triangular biface is discarded.

Chronological Placement: Weir (1976a) places Tortugas points into the San Geronimo and Clear Fork phases. Shafer (in Sorrow, Shafer, and Ross 1967) 


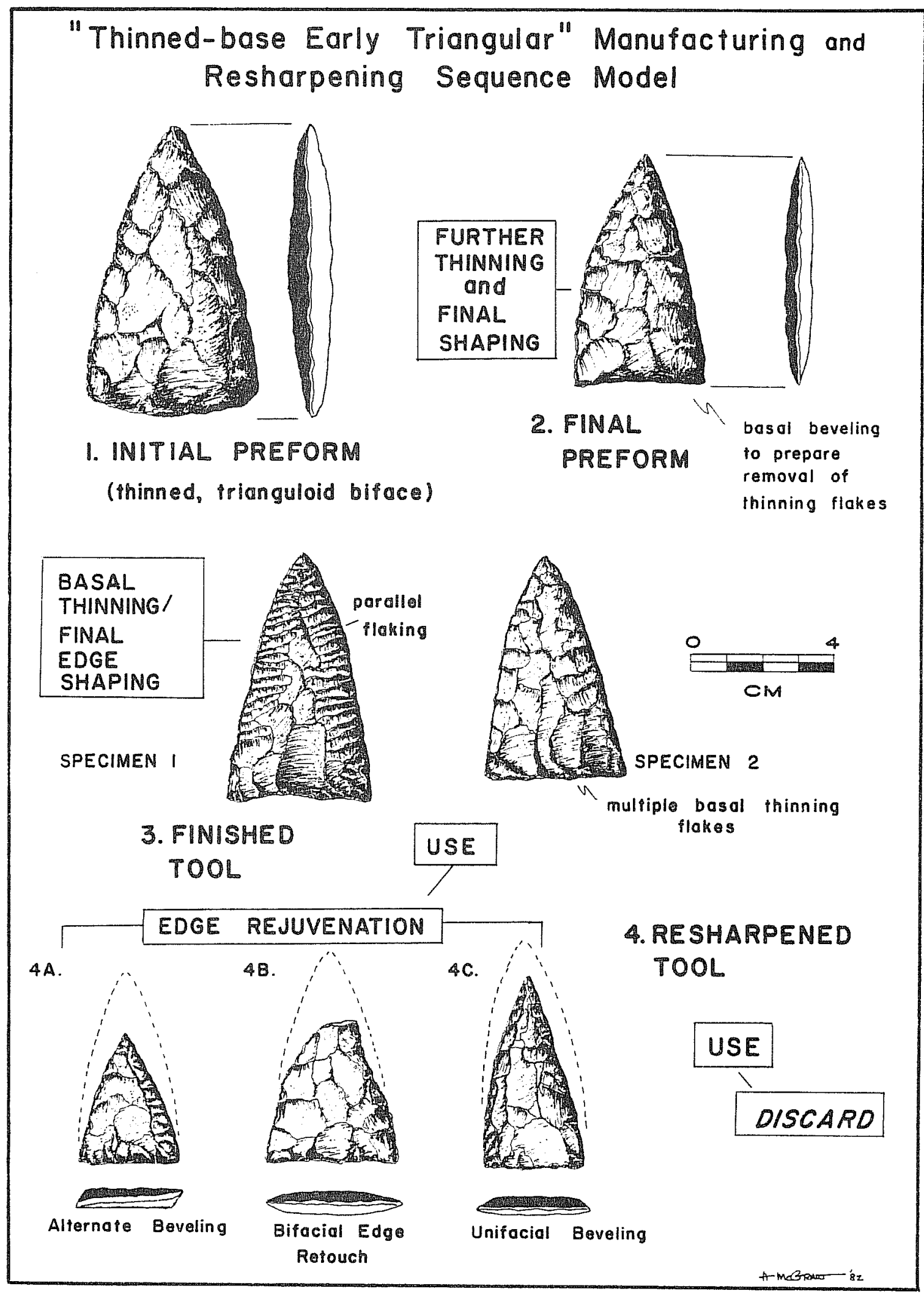
Sequence Model. 
found thinned-base triangular points with Be11 points below Local Period 6 diagnostics at the Lands 1 ide site. Sorrow (1969) found Taylor and Baird points underlying the Local Period 6 occupation at the John Ischy site. Hester (1971) included "Early Triangular" in the "Early Archaic" at the La Jita site, although this period clearly includes Local Periods 5 and 6 materials as defined in this report. At 41 BX 228, D6:3 specimens clearly occur in Local Period 5 contexts and possibly in the lower levels containing Local Period 6 materials. A chronological placement of 4000-2500 B.C. is suggested for $06: 3$.

\section{Q7. Group 7 - Miscellaneous Forms (44 specimens; Figs. 25 and 26)}

A number of specimens were found which do not fit into the above described groups and forms. Overall these miscellaneous forms tend to be unique and are often rather crudely made. Some are perhaps nothing more than reworked specimens which no longer represent their original form. These miscel laneous forms have little value as chronological indicators or for intrasite distributional studies as they occur in small numbers. Most specimens are illustrated in hope that some significance may one day be found by future researchers. Chronological placement is unknown for al1 specimens.

D8. Group 8 - Misce] laneous Unidentifiable Eragments (197 specimens; not illustrated)

D8:1. Form 1 - Midsections, Barbs, and Lateral Fragments (128 specimens)

Group 8, Form 1 includes a 1 arge number of probable dart point fragments, most of which are midsections with some indication of notching. A few may be arrow point fragments or thin biface fragments. No definite identifications can be made, although some fragments strongly resemble certain types. Many are fire fractured.

D8:2. Form 2 - Basal Fragments (69 specimens)

Group 8. Form 2 dart points are represented by a variety of apparent basa 1 fragments. Fragments that could be confidently identified were put in appropriate categories. Form 2 represents basal fragments that could not be identified and were not complete enough to al low reconstruction.

Coding Sequence Numbers: $152,170,218,437,467-470,480,482,497,498$, $510-519,520,522,524-538$, and 540-542.

Uncoded Lot Numbers: $84,99,138,171,380,390,395,397,446,453$, and 458. 


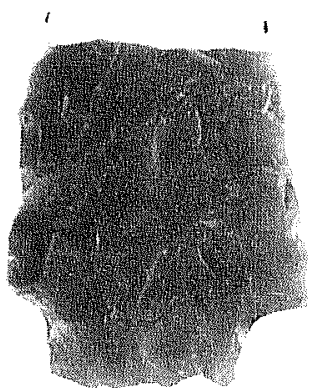

a

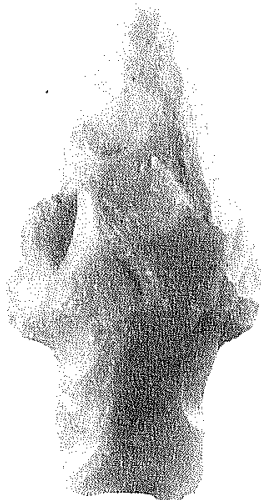

f

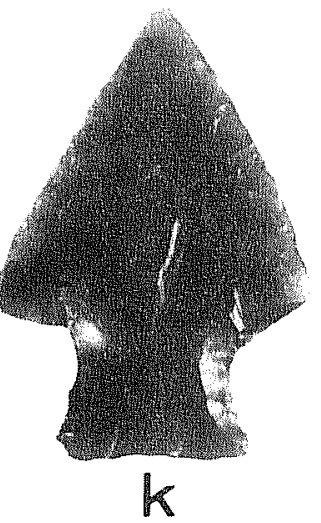

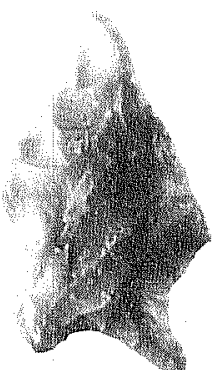

b

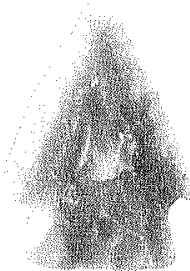

c

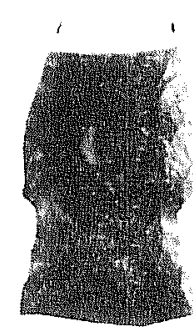

d

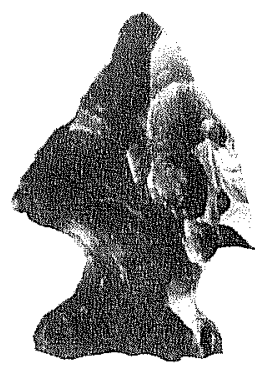

e
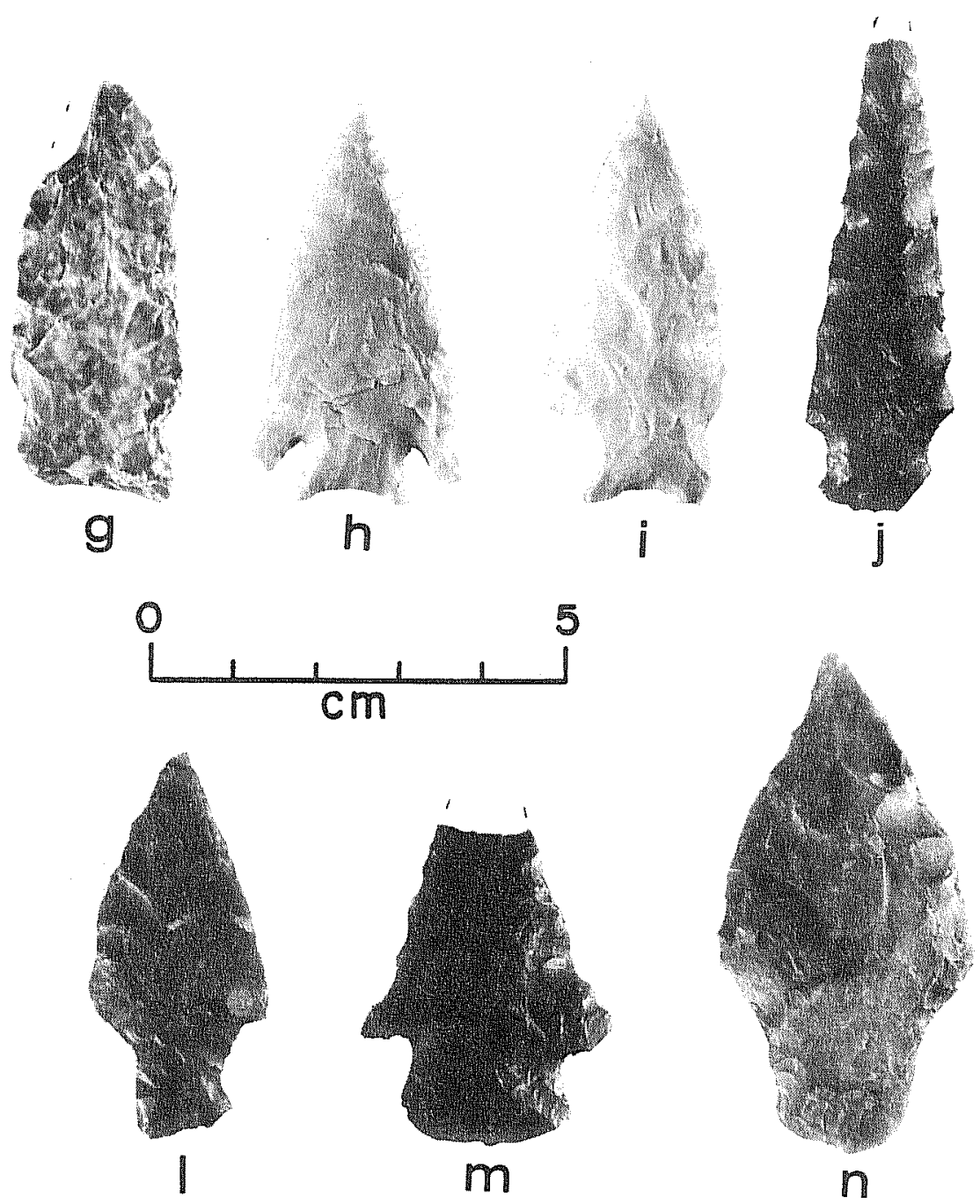

Figure 25. Dart Points, Group 7. a-n, D7, miscellaneous forms. 


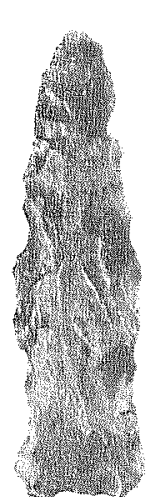

$a$

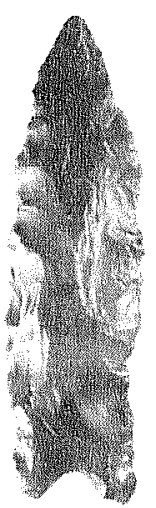

b

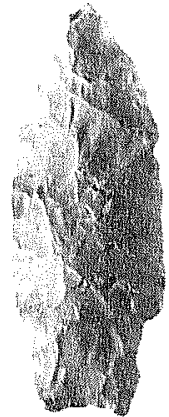

C

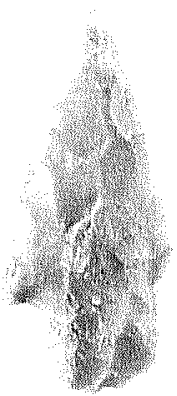

d

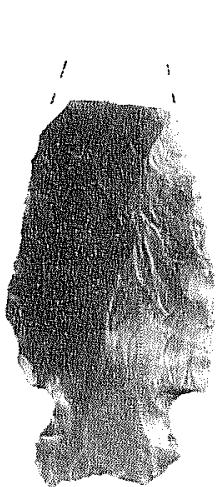

e
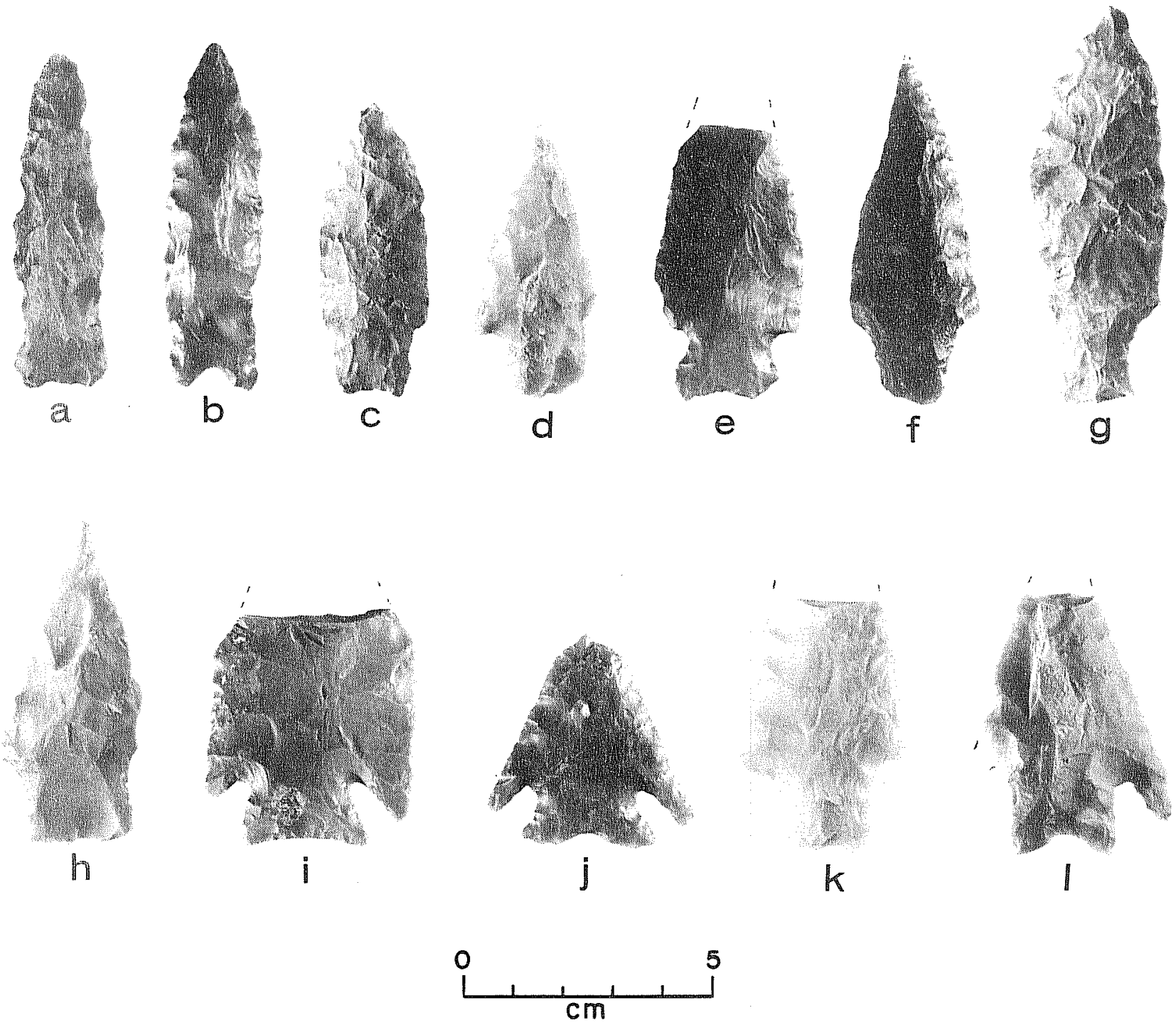

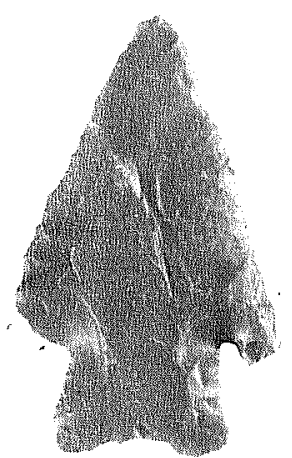

$m$

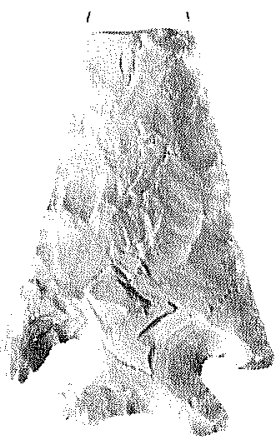

$\mathrm{n}$

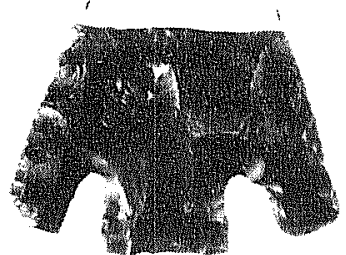

0
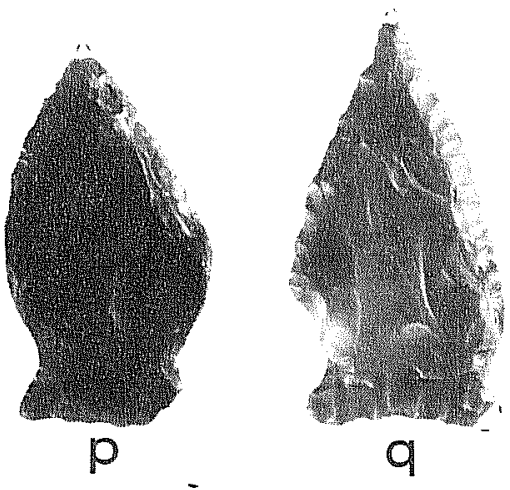

Figure 26. Dart Points, Group 7. a-q, D7, miscellaneous forms. 


\section{Distally Beveled Tools (DB) (Stephen L. B1ack and Lynn Highley)}

A number of distinctive bifacial and unifacial tools and tool fragments, which are commonly referred to as "gouges" or "adzes" in the literature, were recovered from 41 BX 228. Due to the continued uncertainty of the actua 1 function of these so called "gouges" or "adzes," they are herein referred to as "distally beveled tools" following Hall, Black, and Graves (1982). The distally beveled tool collection from 41 BX 228 includes both unifacial and bifacial forms which the authors consider members of the same general tool category. Clear Fork and Guadalupe tools are previously defined formal tool types included within the distally beveled lithic class. A7so included are several forms that are untyped and rarely reported in the archaeological 1 iterature. Project 1 imitations did not al low an equally thorough analysis of each distally beveled tool group. Emphasis was placed on the comparatively poorly known Guadalupe too 1, which is the most numerous distally beveled tool form at the site.

The somewhat unusual configuration of distally beveled tools necessitates the careful definition of certain terms used in describing them. The distal end is the apparent working end or bit of the tool. On a 11 tools the distal end has a beveled or abruptly truncated bit. The distal end is usually wider, thicker, and more carefuliy shaped than the proximal end. The proximal end is usually somewhat pointed and considerably narrower than the distal end. Presumably the proximal end was hafted onto or into a wooden or bone shaft or socket. Howard (1973) has experimented with possible hafting methods of Clear Fork tools. The dorsal side of a distally beveled tool is usually more pronouncedly convex than the ventral side. Cortex, if present, occurs on the dorsal side. A flat unmodified remnant $f l$ ake plane, if present, occurs on the ventral side. The location of the presumed working edge varies according to group or form, occurring along both ventral and dorsal surfaces at the distal end. Lateral edges can be distinguished into left and right edges by orienting the distal end away from the observer with the ventral side down. See Figure 27 for a graphic presentation of these morphological terms.

Metric attribute data are provided for most distal 1 y beveled tool forms. However, these include on $7 y$ the most basic metric attributes (length, width, thickness, and weight). Numerous other attributes, such as wear pattern and edge angle (attribute classes), may be more important in interpreting function. Project 1 imitations did not al low a complete analysis. A careful wear pattern study of the distally beveled tools from 41 . BX 228 would probably require hundreds of man hours. As noted below, a few microscopic wear pattern studies have been applied to several distally beveled tool forms. A11 of these studies have been restricted in scope and have rarely resulted in firm conclusions. The functional interpretations of these artifacts cannot be confidently made until researchers apply thorough and tightly controlled analyses using replicative experiments, as Keeley (1974, 1980 ) and Ode11 (1975) have advocated.

The following groups and forms of distally beveled tools are described based on morphology: 

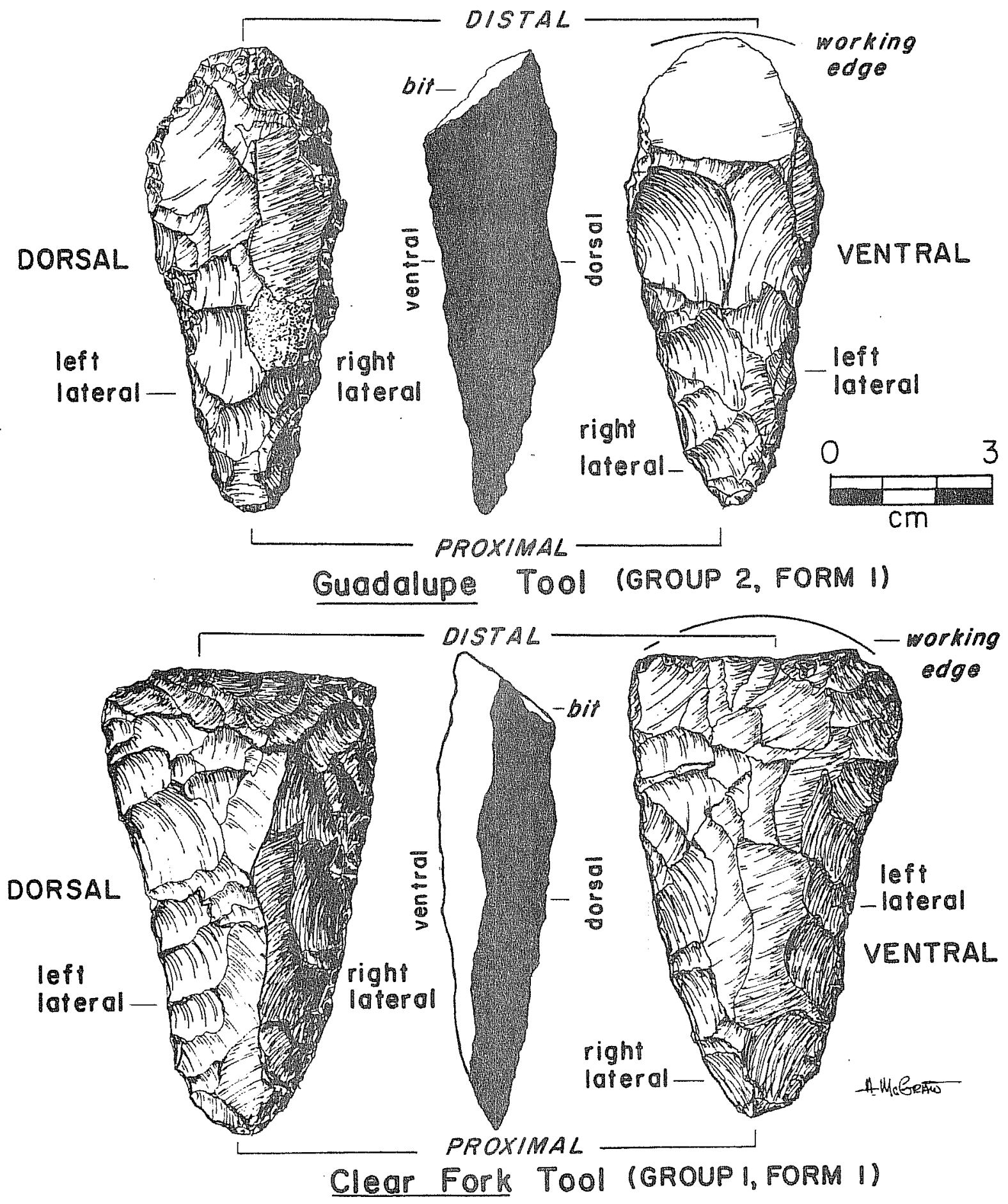

Figure 27. Guadalupe Tool (Group 2. Form 1) and Clear Fork Tool (Group 1. Form 1). 
DB1. Group 1 - Clear Fork Tools

$\mathrm{DBl}: 1$. Form 1 - "Classic" Bifacial

$\mathrm{DBl}: 2$. Form 2 - "Classic" Unifacial

$\mathrm{DBl}$ 3. Form 3 - Miscell laneous

DB2. Group 2 - Guadalupe Tools

DB2:1. Form 1 - Steep Wide Bit

DB2:2. Form 2 - Narrow Bit

DB3. Group 3 - Miscellaneous

$\mathrm{DB} 3: 1$. Form 1 - "Convex-Beveled"

DB3:2. Form 2 - "Shovel-Bit"

$D B 3: 3$. Form 3 - "Rectangular"

DB4. Group 4 - Preforms and Proximal Fragments

$\mathrm{DB} 4: 1$. Form 1 - Preforms

$\mathrm{DB} 4: 2$. Form 2 - Proximal Fragments

\section{DB1. Group 1 - Clear Fork Tools (19 specimens)}

Clear Fork tools have long been recognized as a distinctive tool type. Cyrus Ray (1929, 1930, 1934) first called attention to these artifacts, which he found in the Abilene area. Ray (1941) 1ater described six morphological categories for the tools, which he called clear Fork gouges. Since that time this tool type has been recognized as having widespread spatial distribution in Texas (Hester, Gilbow, and Albee 1973:90; Shiner 1975:186) and northeastern Mexico (Taylor and Rul 1960; Epstein 1969). Comparative studies reveal very similar tool types in Oklahoma (Be 11 1958; Hofman 1977; Hughes 1980), Missouri (Benfer 1972), and New Mexico, Colorado, Nebraska, and South Dakota (Hughes 1980).

A number of studies have been devoted to the functional analys is of Clear Fork tools. However, their function has never been resolved. Ray (1941) postulated that they were used as digging, woodworking, or hide working tools. Later Ray (1959) discounted their use as hide scrapers and added atlatl weights to his list of possible uses. Later researchers have examined clear Fork tools microscopically to answer functional questions by identifying wear patterns. Benfer (1972), in her 1971 study of Clear Fork tools from Missouri, concluded that they functioned as digging and vegetal processing tools. After examining tools from southern Texas, Hester, Gilbow, and Albee (1973) suggested that Clear Fork tools were woodwork ing implements. Chandler (1974) examined specimens from the Falcon Reservoir area of southwestern Texas and suggested that they were used for woodwork ing in a push/plane fashion. Shiner (1975) also suggested that certain morphological forms (triangular with a straight bit) were used in a push/plane fashion, while other forms (ovate with a convex bit) had "scraper wear" and were probably used to thin bison hides.

Temporal control for Clear Fork tools is generally poor. Epstein (1969) found Clear Fork tools associated with Late Paleo-Indian projectile points (Golondrina). Hester (1979a) obtained radiocarbon dates of $70 \%$ B.C. and 
7230 B.C. at Eaker Cave associated with Golondrina points and a Clear Fork tool. Hester (1980:12) suggests that long paral 1el-edged bifacial Clear Fork tools date to Paleo-Indian times, while unifacial forms are more common during the Archaic in south Texas. Hall (in Hall, Black, and Graves 1982) has studied distally beveled tools (principally Clear Fork tools) in the Choke Canyon Reservoir area of south Texas. Hall (ibid.) found that larger forms usually identified as Clear Fork tools dominate earlier Archaic occupations, while smaller untyped tool forms are common in the Late Archaic. Weir (1976a) assigns Clear Fork tools to the San Geronimo and Clear Fork phases in his central Texas cultural sequences.

The extreme $7 y$ wide spatial distribution, the variation in morphology, the variation in inferred function, and the long temporal span would suggest that the Clear Fork tool is not a single tool type. Perhaps the Clear Fork tool as defined represents a general tool form used in various $p l a c e s$ over a long time period for a variety of purposes. The sample from $41 \mathrm{BX} 228$ is relatively smal1, and many of the specimens are from poorly controlled contexts. Hence, it is unlikely that we can answer any of the questions which have been posed concerning the clear Fork tool.

Three morphological forms are defined for the 41 BX 228 Clear Fork tool group. Forms 1 and 2 contain bifacial and unifacial specimens readily identifiable as $\mathrm{Clear}$ Fork tools. The excavated tools in Form 1 and Form 2 come from relatively early contexts and are associated with Local Periods 5 and 6 occupations. Form 3 tools are smaller and less typical of clear Fork tools found in early and later contexts. Metric data for Clear Fork tools from 41 BX 228 are presented in Table 13.

DB1:1. Form 1 - "Classic" Bjfacial (7 specimens; Fig. 28,a-c)

Form 1 specimens are bifacial artifacts readily recognizable as clear Fork tools and, thus, termed "c.1assic." Out 1 ines are triangular to subtriangular; a 11 edges are slightly convex. The cross section of al1 specimens when viewed from the distal end is biconvex. Two specimens become plano-convex toward the proximal end--both have only marginal trimming and retain relatively flat flake surfaces along the centerline of the ventral side. Cortex was present on on $1 y$ one specimen (on the dorsal surface). Three specimens are patinated.

\section{DEl_2. Eorm 2 - "Classic" Unifacial (5 specimens; Fig. 28,d-f)}

Form 2 specimens are unifacial artifacts readily recognizable as Clear Fork tools and, thus, termed "classic." Outlines are triangular to subtriangular; edges are slightly convex to straight. The two smaller specimens (Specimens 1 and 2) have noticeably steeper bits than the larger specimens. This may be due to repeated resharpening. All Form 2 specimens have a flat, unmodified ventral surface. Two specimens retain original flake platforms at the proximal ends. Three specimens have pointed proximal ends, one has a reworked proximal end, and one has a broken or snapped proximal end. One 


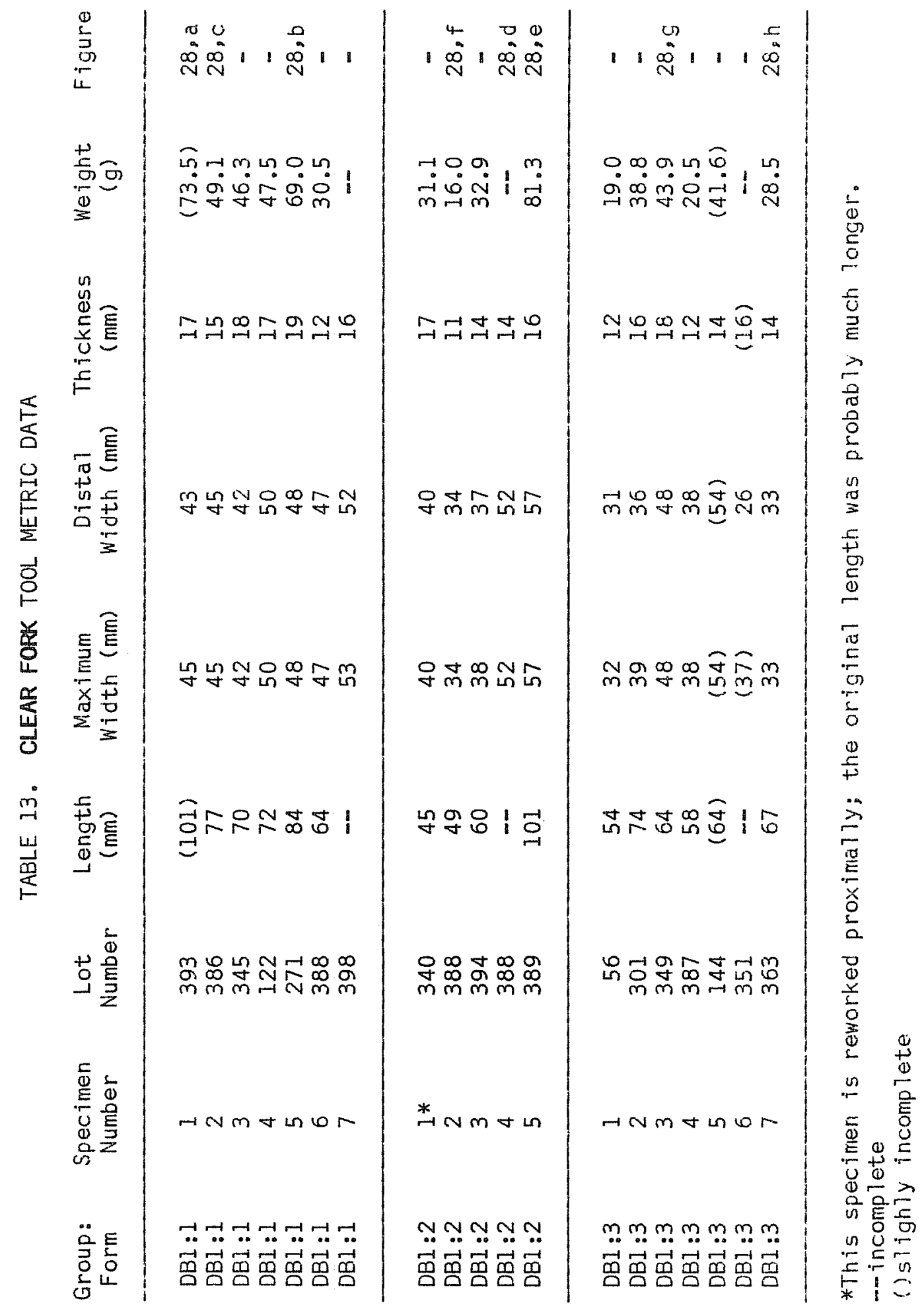




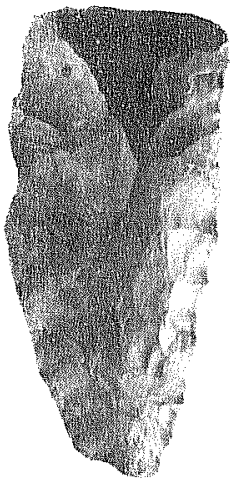

a

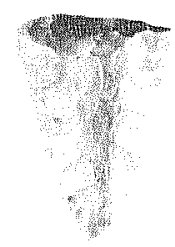

f

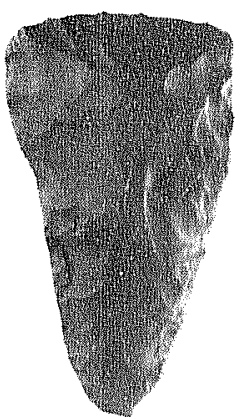

b
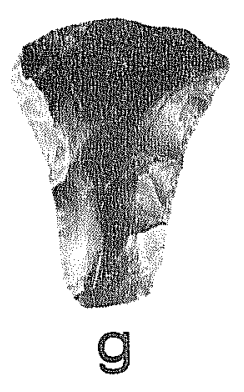

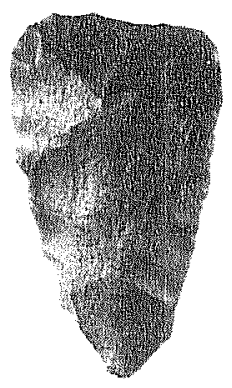

c

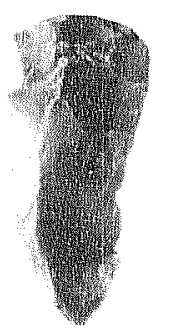

h
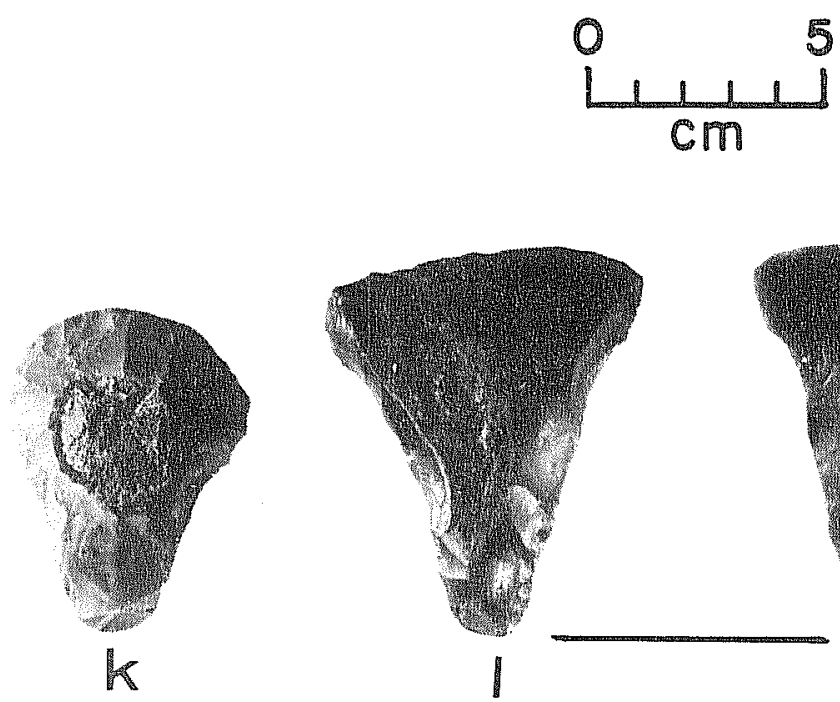

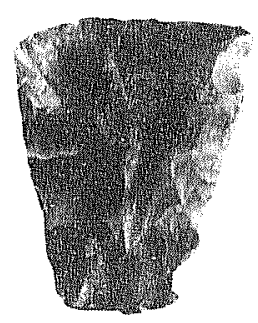

d

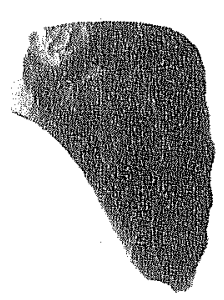

i

\section{5}
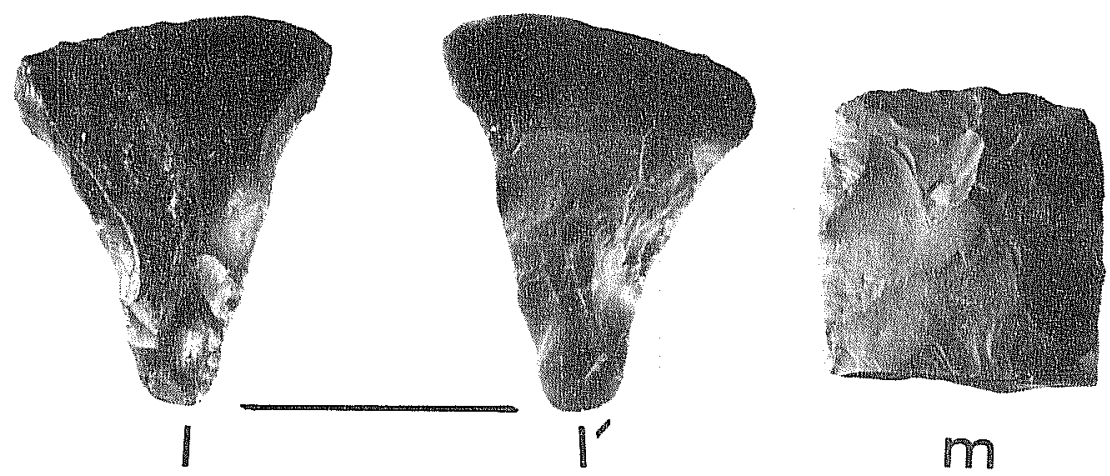

Figure 28. Distaliy Beveled Tools, am $c, D B 1: 1 ; d-f, D B: 2 ; g, h, D B l: 3 ; i, j$, DB3:1; $k-1^{\circ}, \mathrm{DB} 3: 2 ; \mathrm{m}, \mathrm{DB} 3: 3$. 
specimen retains small cortex patches along the dorsal ridge. A11 specimens have plano-convex cross sections.

DBd:3. Form 3 - Miscellaneous (7 specimens; Fig. 28,g,h)

Group 1. Form 3 distally beveled tools fall within the range of norphological forms previously defined as Clear Fork tools. They vary in morphology and are briefly described by specimen number individual ly.

Specimen 1: This tool is a smal1 bifacial artifact with a subtriangular outl ine and convex edges. The cross section is biconvex. The distal surface is completely flaked, while the proximal surface has several large flake facets. The proximal end is bluntiy rounded.

Specimen 2: This specimen has sinuous irregular edges and was probably never completed. The outline is irregular. The cross section is biconvex.

Specimen 3: This artifact has an unusual outline. The lateral edges are concave, the distal edge is strongly convex, and the proximal edge is squared off. The cross section is biconvex. Most of the flaking is on the dorsal surface. The chert is glossy and tinted red--a probable indication of heat treatment.

Specimen 4: This sma11, triangular tool appears to have been a unifacial tool which has been resharpened and battered. The cross section is planoconvex. Patination is heavy.

Specimen 5: This specimen is rather short and wide--almost equilatera1. The out 1 ine is subtriangular with convex edges. The cross section is biconvex. Two corners of the artifact are battered.

Specimen 6: This specimen is a distal fragment of a long narrow bifacial tool. The bit is relatively small and narrow.

Specimen 7: This tool is irregularly shaped and flaked. It may represent a resharpened and battered tool rather than an unfinished tool. The cross section is $\mathrm{p} 7$ ano-convex, and the outline is subtriangular with convex edges.

\section{DB2. Group 2 - Guadalupe Tools (16 specimens)}

The Guadalupe tool, although long recognized as a unique tool form, has never been formally defined. This discussion will summarize published and unpubl ished data available on the Guadalupe tool and offer new data based on a study of the 41 BX 228 specimens; thus, it can be considered a formal definition.

The Guadalupe tool is a thick percussion-flaked artifact with a very abruptiy truncated distal end. It is the truncated distal end or bit which gives the Guadalupe tool its unique appearance. Unlike most other distally beveled tools, such as the Clear Fork tool (Group 1), the Guadalupe tool has a 
truncated bit that angles from the dorsal rather than the ventral edge toward the proximal end and ventral surface. The bit morphology varies considerably but usually has a single-faceted, almost flat appearance. The presumed working edge generally occurs as a semicircular arc along the dorsal surface/distal surface interface. The working edge is usually unifacially worked on the dorsal surface, where use-damage or scarring is commonly $v$ isible to the unaided eye. Cross sections vary from biconvex to p 1 anoconvex to keel shaped or almost triangular. The diversity of Guadalupe tool morphology may be attributed to functional and technological differences. Known Guada 1 upe tool occurrences strongly suggest a 1 imited temporal and spatial distribution.

Previous Designations: The term "Guadalupe adz" or "gouge" was first applied to these artifacts by T. N. Campbell (personal communication) in the early 1950 s in conversations with colleagues and students at The University of Texas at Austin. Campbe 11 borrowed the "Guadalupe" designation from E. B. Sayles' (1935) classic publication. Archaeological Survey of Texas. Sayles (ibid.:134d) illustrated a Guadalupe tool, which he called a "core scraper, with plane base," and considered it diagnostic of his Guadalupe River Phase. A contemporary monograph on archaeological sites in Bexar County mentions "the so-called 'Buffalo scraper', named by Attwater" (Wool ford 1935:5-6). Wool ford described the "Buffalo scraper" as "a triangular length of flint with a bevel face, flaked into a scraper edge, with signs of use at the sides and the other end unfinished." Unfortunately, no illustration is included, although the description does seem to fit the Guadalupe tool. This may we 11 be a clue to the source of the term "Attwater adz" (Hester and Kohnitz 1975:22), which has also been applied to the Guadalupe tool. H. P. Attwater was a late 19 th-century promoter who worked for the railroads in Texas. Attwater collected a 11 things Texan and displayed his collection at fairs all across the country to encourage people to move to Texas and buy 1 and. His collection, which contained (among many other things) over 800 prehistoric artifacts, was the beginning of San Antonio's Witte Museum in the $1920 \mathrm{~s}$ (Woolford and Quil 1 in 1966). The Attwater collection must have included Guadalupe tools and given rise to the terms "Buffalo scraper" and "Attwater adz." The authors, fol lowing Hester and Kohnitz (1975), suggest the use of the term Guadal upe tool rather than "adz" or "gouge" in recognition of the continued functional uncertainty.

Geographis Distribution: Previous researchers have suggested that the Guadalupe tool occurs most frequently along the San Antonio and Guadalupe Rivers (Campbe11 1962; Fox et a 1. 1974:40; Hester and Kohnitz 1975:22; Hester 1980:114). In an effort to examine the distributional pattern more carefully, the authors located as many published and unpublished references to Guadalupe tool occurrences as possible. This information is presented county by county in Table 14. Figure 29 shows the approximate known geographical extent of the Guadalupe tool. Based on this study, the geographical extent is far beyond the Guadalupe and San Antonio Rivers drainages across most of the south Texas Gulf Coastal Plain. To the north and northwest, the Balcones Escarpment forms the boundary, al though a few occurrences have been reported on the eastern edge of the Edwards Plateau (Footbridge site [Suhm and Jelks 1962]). To the west and southwest, they are found in small numbers along the Rio Grande Valley as far south as the Falcon 
TABLE 14. GUADALUPE TOOL OCCURRENCE REFERENCES BY COUNTY

\begin{tabular}{|c|c|}
\hline County & Reference \\
\hline Atascosa & Hester 1968 \\
\hline Bastrop & Duke $1977 *$ \\
\hline Bexar & $\begin{array}{l}\text { Hester and Kohnitz 1975; Chadderdon 1975; McGraw 1977; Erown } \\
\text { et a 1. 1977; Gerst1e, Ke11y, and Assad 1978; Va1dez 1979; } \\
\text { McGraw and Marsha11 1982 }\end{array}$ \\
\hline Coma 1 & Suhm and Jelks 1962; Gerstle, Kelly, and Assad 1978 \\
\hline Dewitt & Fox et al. 1974 \\
\hline Dimmit & T. R. Hester, personal communication \\
\hline Fayette & F. A. Weirs personal communication \\
\hline Frio & Hester 1968 \\
\hline Goliad & Fox, Black, and James 1979 \\
\hline Gonzales & Fox et a1. 1974 \\
\hline Jackson & S. Schmiedlin, personal communication \\
\hline Karnes & 41 KA 46 survey records on file at TARL and CAR-UTSA* \\
\hline Live Oak & Ha11, Black, and Graves 1982 \\
\hline McMullen & $\begin{array}{l}\text { Hester 1968; Lynn, Fox, and O'Ma11ey 1977; Ha11, B } 1 \text { ack, and } \\
\text { Graves } 1982\end{array}$ \\
\hline Uvalde & Evans and Campbell ms. \\
\hline Victoria & $\begin{array}{l}\text { Campbe } 11 \text { 1962; Fox and Hester 1976; Birmingham and Hester } \\
\text { 1976; Calhoun 1965 }\end{array}$ \\
\hline Webb & Saunders and Saunders 1978* \\
\hline Zapata & Kotter 1980 \\
\hline Zavala & $\begin{array}{l}\text { L. Highley, personal communication; T. C. Kelly, personal } \\
\text { communication }\end{array}$ \\
\hline
\end{tabular}

*possible or unconfirmed occurrences 


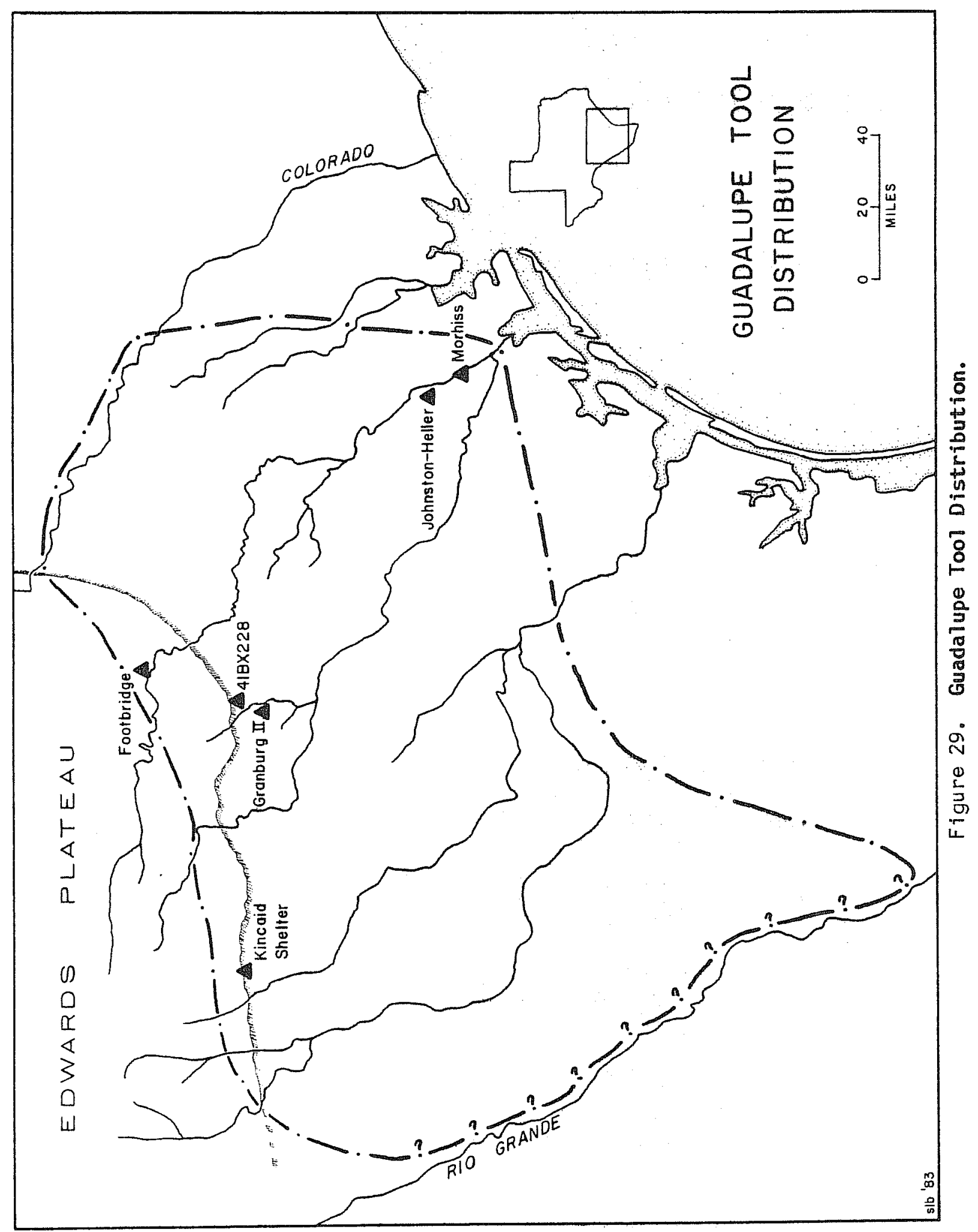


Reservoir area (Kotter 1980). From there the reported extent runs north to just south of the confluence of the Nueces and Frio Rivers. To the southeast they are found down the San Antonio River and the Guadalupe River almost to the coast. Occasional occurrences have been reported east of the Guadalupe River as far as the Colorado River valley. They have not been reported across most of central Texas, in east Texas, along the Gulf Coast, in extreme south Texas, or in the Pecos area.

The distribution pattern appears to be closely 1 inked with the drainage systems flowing toward the Gulf Coast off the Edwards Plateau. The heaviest concentrations occur in two areas, the lower and middle Guadalupe River and the upper drainage system of the San Antonio River. The frequent occurrence of Guadalupe tools in the 1 ower Guadalupe area has been noted by Campe 11 (1962) at the Morhiss site and by Calhoun (1965), who commented in reference to Morhiss focus (Archaic) sites that "The Guadalupe Adz is common to all sites." Other references to Guadalupe tools from the middle and lower Guadalupe River and associated secondary drainages include Fox et a 1. (1974); Fox, Black, and James (1979); Fox and Hester (1976); and Birmingham and Hester (1976).

Guadalupe tools are especially common in Bexar County within the upper drainage system of the San Antonio River. Woolford (1935:5) specifically states: "Here [in reference to the stream valleys in north Bexar County] is found in its greatest profusion the so-called 'Buffalo scraper'. . ." fissuming that the "Buffalo scraper" is indeed the Guadalupe tool, Woolford's comment is especially significant because he was an amateur archaeologist (and newspaperman) who roamed much of Bexar County before encroaching urbanism destroyed many sites. Guadalupe tools are common in undocumented artifact collections from the upper Salado Creek watershed which have been shown to CAR staff members. Additional Bexar County references are 1 isted in Table 14.

The above-noted concentrations probably reflect the intensity of archaeological work as well as actual concentrations of the tool. As more work is done in the fringe areas of the Guadalupe tool's distribution, the boundaries wi1 1 probably be expanded.

Chronelegical Considerations: Hester and Kohnitz (1975) reported the occurrence of Guadalupe tools at the Granberg II site in stratigraphic contexts clearly 1 inked to Early Archaic or Pre-Archaic occupations. Later, a radiocarbon date of 3600-3400 B.C. (MASCA calibration) was obtained for the upper portion of this zone which contained Guadalupe tools (Hester 1979a). A similar date of $3380 \pm 170$ B.C. (MASCA calibration) was obtained from 41 BX 228 (see An Overview of the Prehistory of the Upper Salado Creek Watershed section) for the zone containing Guadalupe tools and other Local Period 5 diagnostic artifacts. Elsewhere Guadalupe tools have not been reported in datable contexts, although they are generally recognized as Archaic artifacts. Weir (1976a) includes Guadalupe tools with in his rather long-1 ived San Geronimo phase (6000t to 2500 B.C.).

It is not possible to conclusively date the occurrence of Guadalupe tools based on only two radiocarbon dates and 1 imited stratigraphic information. 
However, it is suggested that the Guadalupe tool is definitely an Early Archaic artifact form 1 imited perhaps to a relatively brief portion of the Early Archaic, ca. 3500 B.C. (Local Period 5).

Iechnological Considerations: The morphological characteristics of the distinctive bit or distal surface of the Guadalupe tool indicate that at least two different methods of manufacturing were employed. Evans and Campbel1 (ms.), in their unpublished report on the Kincaid site, suggest that the Guadalupe tool bit".. Was formed by removal of a single transverse flake, the blow being struck against the dorsal face of the tool... " Fox (Fox et a 1. 1974:40) suggested that specimens from the proposed Cuero Reservoir had bits".. formed initial 1 y by percussion removals from the dorsal or convex surface, and then by shaping the end into a blunt though pointed shape by percussion-flaking from the ventral surface..." Both of the above outlined bit formation schemes result in distal surfaces which display single or multiple negative flake scars.

Many of the Guadalupe tools from 41 BX 228 and other San Antonio area sites such as Granberg II (4I BX 271) have a curiously flat distal surface which notably 1 acks any indication of a negative flake scar(s). A number of colleagues at the CAR offered the opinion that a single flake removal could result in these flat surfaces without noticeable negative flake scar indications. The senior author and one such colleague were, however, unable to remove such a flake from experimental thick bifaces without leaving the characteristic negative flake scar. The senior author remained perplexed until another colleague, Kenneth M. Brown, carefully examined the 41 BX 228 specimens and offered an alternative explanation. Armed with a split cobble and a small hammerstone, Brown demonstrated his explanation by quick ly (1ess than 10 minutes) producing a Guadalupe tool replica virtually identical to the Form 1 specimens from 41 BX 228.

Model No. I (Fig. 30) il 1 ustrates the manufacturing sequence Brown used to reproduce a Guadalupe too1. The most important aspect of this model is that the tool is formed from a core trimming flake rather than a thick biface. The $f l a t p l a n e$ or bit is formed before the $f l$ ake is removed from the core. During the process of flake removal from a single-faceted core platform (for examp 1e, a split cobble), the angle of removal eventually becomes too acute $\left(90^{\circ}\right.$ is idea 1 ), resulting in undesirably short $f 1$ akes (K. M. Brown, personal communication). The knapper is forced to "reset" the desired angle by striking the platform 4-6 cm away from the overhanging edge. The resulting core trimming $f 1$ ake is an ideal preform for a Form 1 Guadalupe tool. The remaining manufacturing sequence involves percussion removal of flakes from both lateral edges on both the dorsal and ventral surfaces; thus, thinning and shaping the tool. This process usually removes any trace of a positive bulb of percussion on the ventral surface. The resulting tool usually has a subtriangular cross section, or a slightly convex ventral and marked ly convex dorsal. The last step in the sequence (not il1ustrated) involves minor trimming around the dorsal edge of the bit to create the desired semicircular shape of the working edge. Model No. I calls to mind Sayles' 1935 work in which he refers to the Guadalupe tool as a "core scraper, with plane base." 
GUADALUPE TOOL Manufacturing Soquence. Model No. I

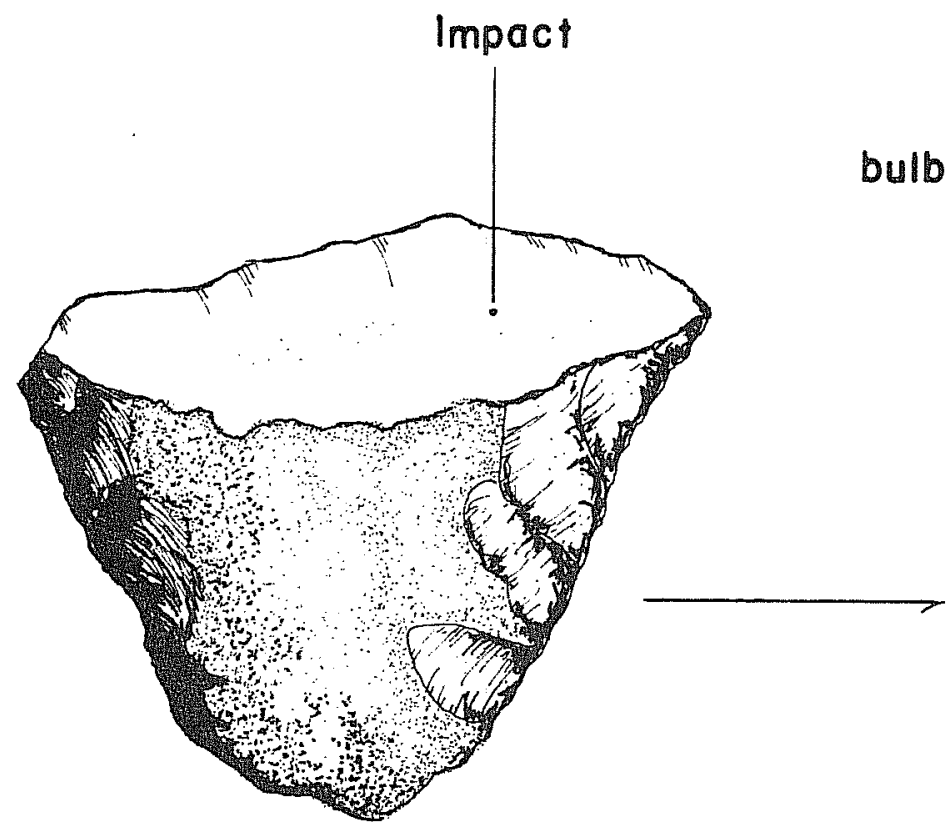

I. SPLIT COBBLE

ventral

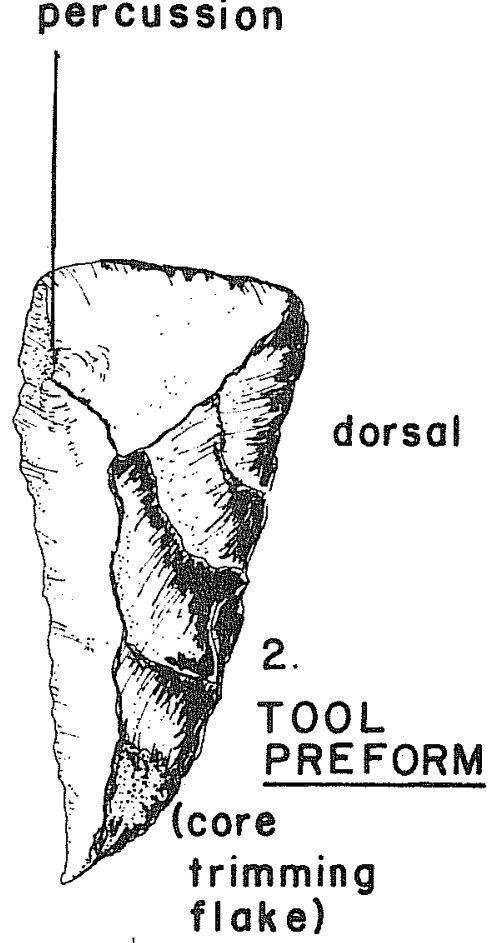

distal
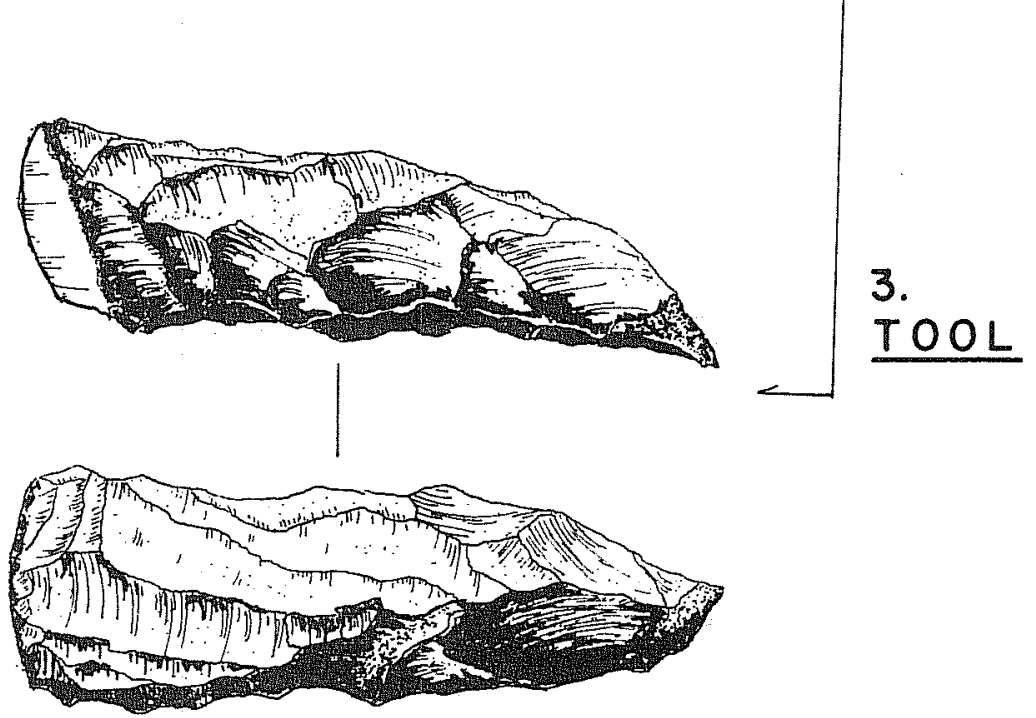

bulb of percussion removed, tool is bifacially thinned to size and

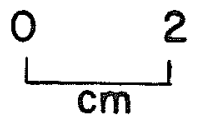

$$
\text { shape }
$$

Figure 30. Guadalupe Tool Manufacturing Sequence, Model No. 1. 
Model No. 1 does not explain how al1 Guadalupe tools were made, particularly the above-quoted examples from other sites. These Guadalupe tools exhibit biconvex or plano-convex cross sections and a negative flake scar(s) on the distal bit. Model No. 2 (Fig. 31) il lustrates the manufacturing sequence that the authors bel ieve explains these attributes. Model No. 2 follows previous researchers suggestions. The sequence begins with a percussionflaked thick elongated core biface which is then preformed into a bipointed thick biface. One end of the bipointed biface is removed with a single or multiple blows resulting in the distal bit, which bears negative flake scar(s). The final step involves marginal trimming of the bit and lateral edges until the desired shape is obtained.

Eunctional Considerations: Guadalupe tools are generally thought to have been hafted woodworking tools. Evans and Campbel1 (ms.) suggested "... that these tools were hafted transversely and used for wood-cutting purposes. The bits sometimes show battered edges, suggesting heavy usage, and a 11 fragments (six specimens) show transverse breaks. . " As Hester and Kohnitz (1975) note, no systematic wear pattern studies or replicative experiments have ever been pub 1 ished to confirm these suggestions. One unpublished study (Jaquier 1976) of Clear Fork and Guadalupe tools involved limited microwear examination. However, the results were inconclusive.

An alternative to the woodworking hypothesis was suggested by $J$. $B$. Sol lberger (personal communication 1982). Sollberger argues that "the edge type and character [of Guada]upe tools] is unsuitable for working wood" and that "few if any were hafted." Sollberger's alternative ideas on the Guadalupe tool are discussed in an unfinished manuscript that he graciously provided a copy of (Sol1berger and Carrol $1 \mathrm{~ms}$.). Sol 1 berger and Carrol 1 bel ieve that the Guadalupe tool is a specialized tool form used with other chert and/or bore tools that make up a "hide defleshing kit." Specifically, they hypothesize that the Guada 1 upe tool was used as a "membrane cutter1 ifter." Sollberger and Carroll discuss in some depth the steps necessary to preserve an animal hide. One necessary step is to remove the tough tissue membrane that traps fatty oils against the animal hide. They argue that the Guadalupe tool is ideally suited as a hand-held tool used with the bit placed flat against the hide and the proximal end pointing up to cut and 1 ift off membrane without damaging the hide. Once the membrane has been removed then a gougel ike tool such as the Clear Fork tool can be used to remove the "freed fatty oils."

The final functional interpretation of the Guadalupe tool awaits a detailed study involving microwear analysis and experimental replications to test the various hypothesized functions. A macroscopic examination of Guadalupe tools from 41 BX 228 reveals the same observations that others have made about this artifact which may relate to function:

(1) the Guadalupe tool is relatively heavy in comparison to most other chipped stone tools;

(2) the distal surface shows little or no sign of obvious edge damage or resharpening; 
GUADALUPE TOOL Manufacturing Sequence Model No. 2
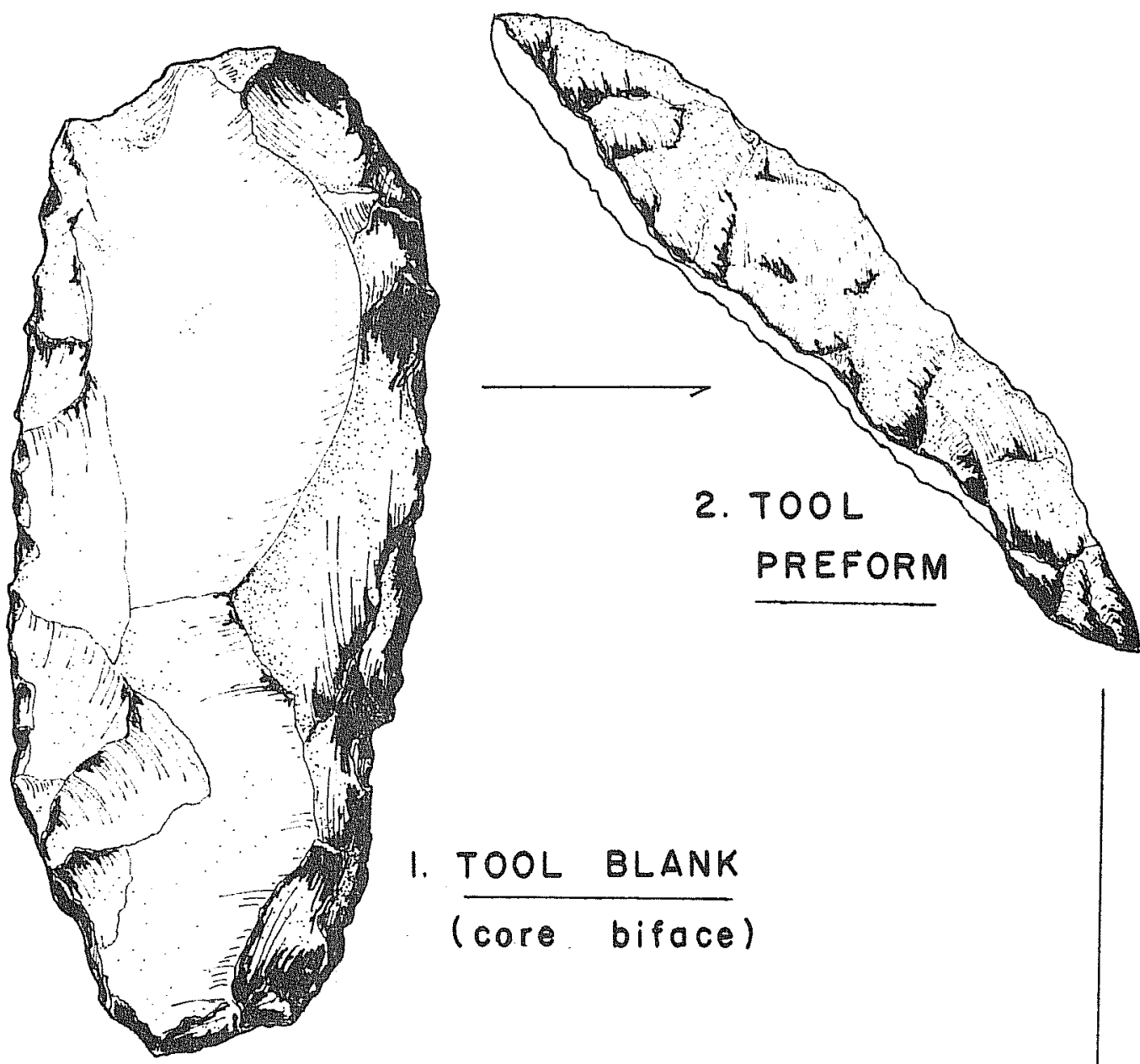

I. TOOL BLANK

(core biface)

impace

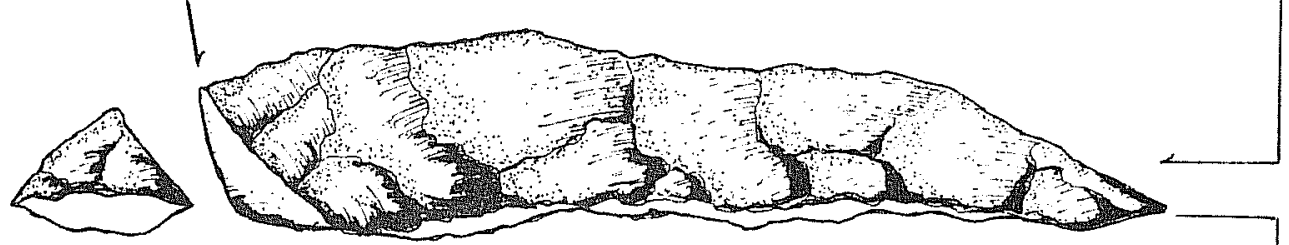

3. distal working edge produced

TOOL

0

3
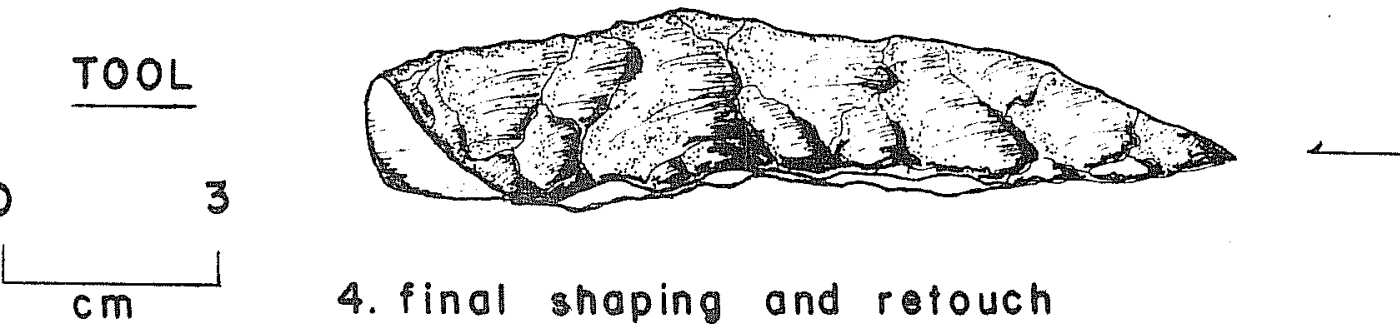

4. final shoping and refouch

Figure 31. Guadalupe Tool Manufacturing Sequence, Model No. 2. 
(3) the dorsal surface along the curved distal bit does show obvious edge damage, and frequently shows resharpening;

(4) broken specimens have transverse breaks that may have resulted from a snap fracture caused by extreme pressure against the working edge while the tool was hafted or from overshot resharpening flakes detached while the tool was hafted; and

(5) the working edge angles are generally steep. roughty ranging from $55-85^{\circ}$.

DB2:1. Form 1 - Steep Wide Bit (13 specimens; Fig. 32,a-d)

Group 2, Form 1 includes eight finished tools, three unfinished or rejected tools, and two finished distal fragments. The following description is based on the finished tools or tool fragments. Formal specimens have a truncated distal end with a tapered, generally pointed proximal end. Form 1 specimens are comparatively thick (thickness $>2 / 3$ width), percussion-chipped artifacts. The maximum width usually occurs within the distal one-third of the artifact but never at the bit. Cross sections are usually $\mathrm{p} 7$ ano-convex (keel shaped), common $7 y$ irregular, and very rarely (one specimen) biconvex. The dorsal surface usualiy has an irregular central ridge which on one specimen is so pronounced that it has been used as a flaking platform, thus, creating a truly trifacial artifact. Cortex is present on five specimens, three along the dorsal ridge and two on the proximal end. All specimens are made from typical Edwards chert (tan, gray, or brown) and do not appear heat treated.

The distal surface or bit is flat or slightly concave on a 11 specimens. Most specimens appear to fit the Model No. 1 manufacturing sequence. The exceptions are those with negative flake scar ripple marks visible on the distal surface which appear in most other aspects to resemble the other specimens. It is suggested that these were originally made via Model No. I and 1 ater resurfaced with a single blow to the dorsal ridge. The working edge along the distal/dorsal edge is carefully shaped into a semicircular or convex unifacial edge. Obvious use-damage and resharpening appears to originate along the working edge but only on the dorsal surface. This almost certainly results from use-pressure or billet flaking applied to the working edge from the distal end toward the proximal end.

Metric attribute data are summarized in Table 15. Specimens considered unfinished were not used for this summary. Fragmentary specimens were used only to measure intact attributes. The resulting data are based on a small sample (eight to nine cases) and, thus, must be used with caution. Width and thickness attributes are noticeably more consistent than length and weight.

Lot Numbers: E7, 344 (four specimens), 345 (two specimens), 351, 389 (three specimens), 394, and 479. 

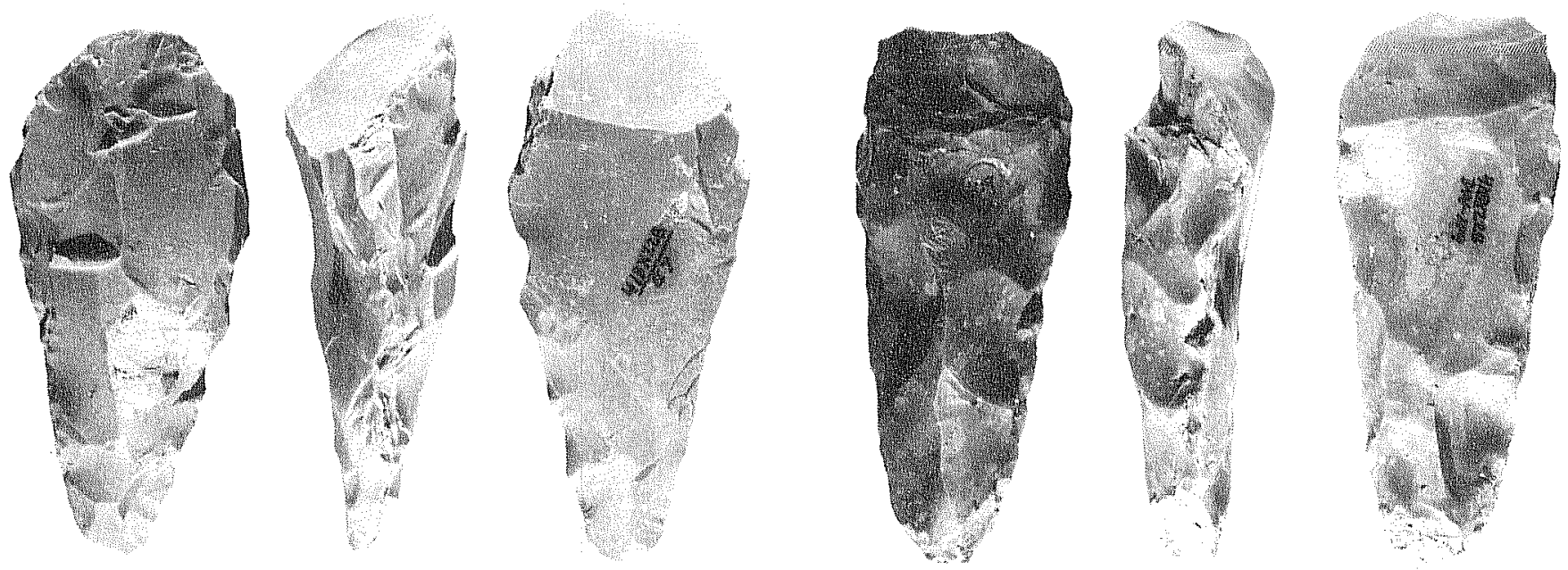

a
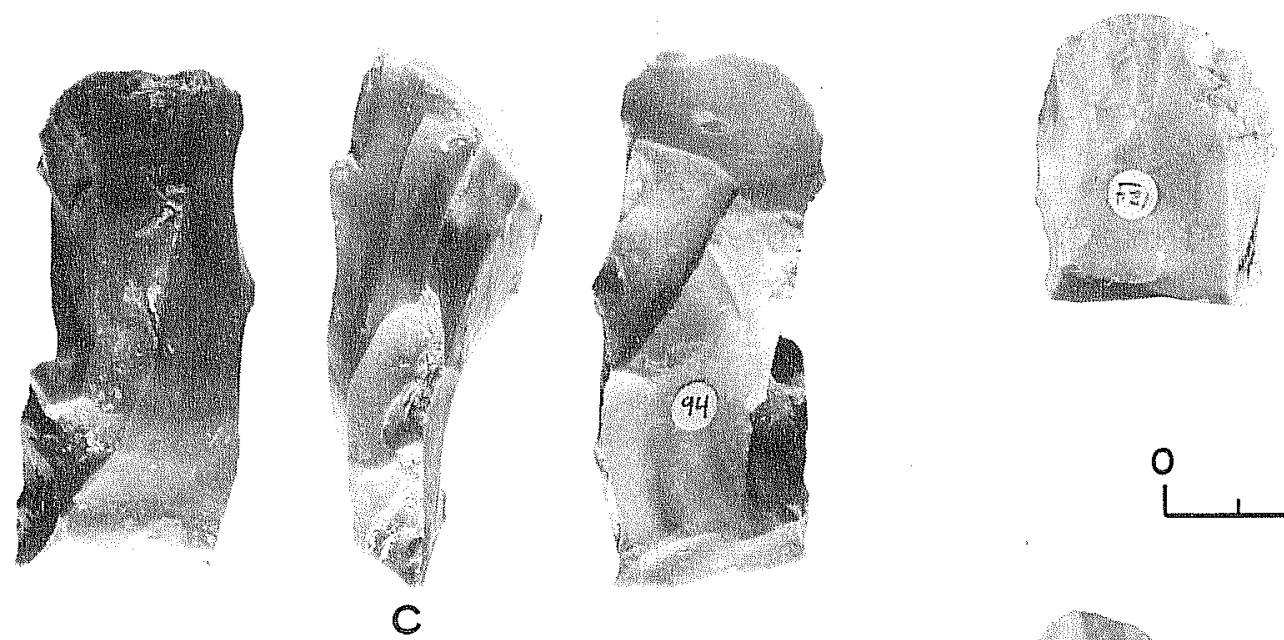

b
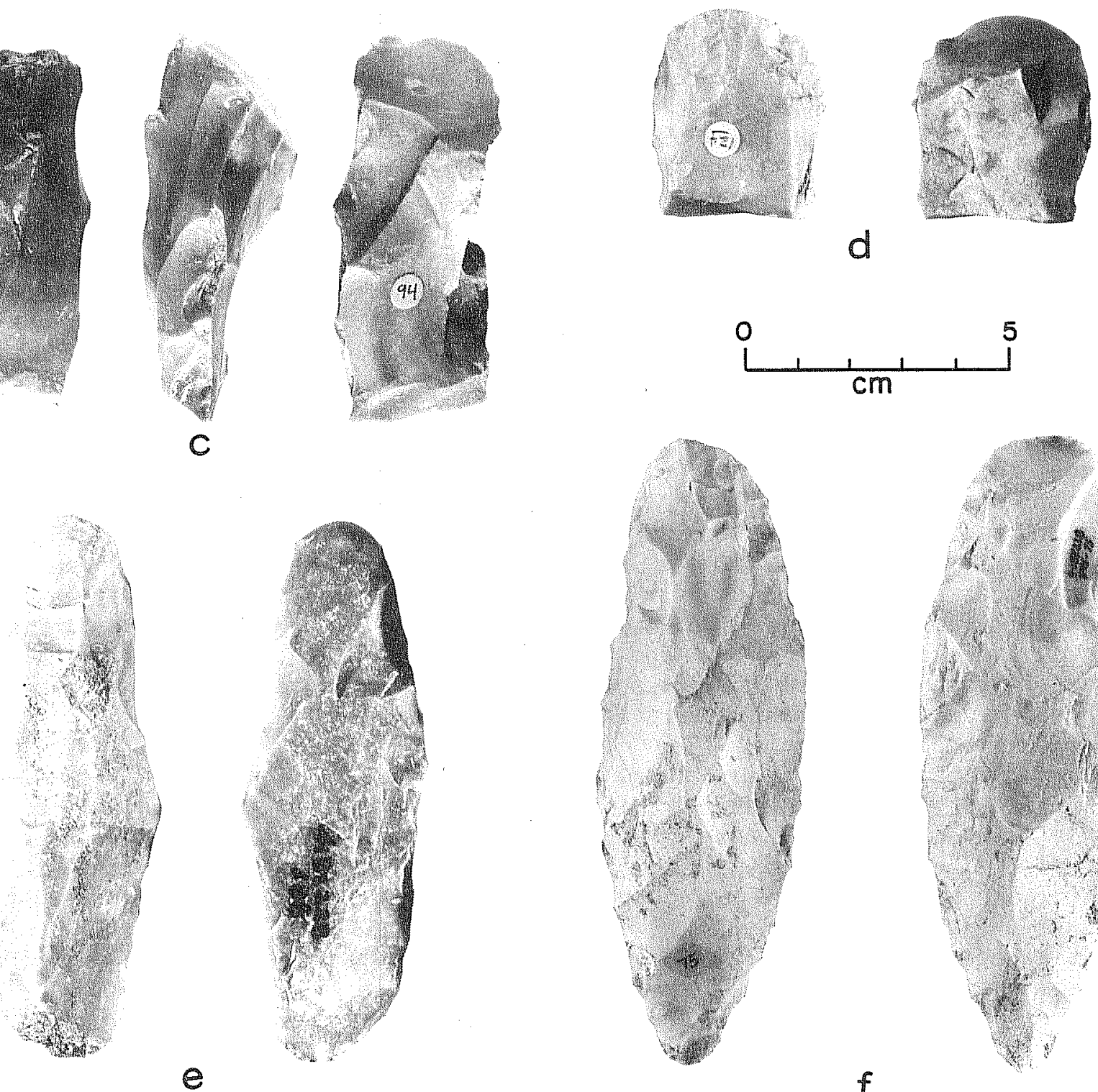

Figure 32. Distally Beveled Tools, Group 2, Guadalupe Tools. a-d, DB2:1; $e, f D B 2: 2$. 
TABLE 15. GUADALUPE TOOL FORM 1, METRIC ATTRIBUTE DATA 1

Number

of Cases

\begin{tabular}{|c|c|c|c|c|c|c|}
\hline Attribute & $\begin{array}{l}\text { of Cases } \\
(N)\end{array}$ & Maximum & Minimum & Mean & Variance ${ }^{2}$ & $\begin{array}{l}\text { Standard } \\
\text { Deviation } 3\end{array}$ \\
\hline Length & 8 & 95.0 & 74.0 & 82.6 & 37.2 & 6.5 \\
\hline Maximum Width & 9 & 38.0 & 30.0 & 34.1 & 6.1 & 2.6 \\
\hline Distal Width & 9 & 35.0 & 26.0 & 30.1 & 12.5 & 3.8 \\
\hline Thickness & 9 & 30.0 & 19.0 & 23.8 & 14.2 & 4.0 \\
\hline Weight & 8 & 77.5 & 53.6 & 65.6 & 59.2 & 8.2 \\
\hline
\end{tabular}

\section{DB2:2. Form 2 - Narrow Bit (3 specimens)}

Group 2, Form 2 specimens are morphological1y distinct from Form 1 specimens, but do constitute a homogeneous category. They share the common distinction of having a narrower bit than Form 1 specimens. Due to the small sample size and diversity among these specimens, they are described individual1y. Table 16 provides metric attribute data for Form 2.

Specimen 1 (Fig. 32,e): This artifact has a lenticular out1ine with a narrower, more pointed proximal end. The cross section is biconvex, although the ventral side is noticeably less convex. Specimen 1 is noticeably bifacial and appears to be an excellent example of a Guadalupe tool manufactured $v i a$ Mode 1 No. 2. This specimen is the most careful 1 y shaped Guadalupe tool from 41 BX 228. The bit, formed by a single blow originating at the dorsal ridge, is comparatively small, narrow, and triangular.

Specimen 2 (Fig. 32,f): This specimen has parallel edges with rounded ends. The cross section is plano-convex. The dorsal side has a high dorsal ridge. Cortex covers the proximal end and extends along the dorsal ridge for several centimeters. The distal bit is longer, narrower, and much less steeply angled than form 1 specimens. Specimen 2 does not readily fit either manufacturing sequence model, although it appears more closely related to Model No. 1 specimens. The bit has been carefully shaped by flaking on the dorsal surface along the working edge. Edge damage is not apparent. 
TABLE 16. GUADALUPE TOOL FORM 2, METRIC ATTRIBUTE DATA

\begin{tabular}{ccccccc}
$\begin{array}{c}\text { Specimen } \\
\text { Number }\end{array}$ & $\begin{array}{c}\text { Lot } \\
\text { Number }\end{array}$ & $\begin{array}{c}\text { Length } \\
(\mathrm{mm})\end{array}$ & $\begin{array}{c}\text { Maximum } \\
\text { Width }(\mathrm{mm})\end{array}$ & $\begin{array}{c}\text { Distal } \\
\text { Width }(\mathrm{mm})\end{array}$ & $\begin{array}{c}\text { Thickness } \\
(\mathrm{mm})\end{array}$ & $\begin{array}{c}\text { Weight } \\
(\mathrm{g})\end{array}$ \\
\hline 1 & 345 & 115 & 38 & 22 & 23 & 95.8 \\
2 & 388 & 89 & 25 & 24 & 21 & 45.0 \\
3 & 483 & 100 & 33 & 25 & 20 & 62.4 \\
\hline
\end{tabular}

Specimen 3: This tool has an irregular outline; the distal end is rounded and narrower than the blunt, cortex-covered proximal end. The cross section is biconvex, although the ventral surface is noticeably less convex. Unlike a 11 other Guadalupe tools from 41 BX 228, the distal bit of Specimen 3 has been shaped by multiple flake scars. The bit is noticeably smaller and less steep than Form 1 specimens.

DB3. Group 3 - Miscellaneous Distally Beveled Tools (11 specimens)

Group 3 includes a variety of chipped stone tools which have apparent beveled working ends. Some Group 3 artifacts probably represent functional tools, while others are probably beveled only as a step during bifacial thinning. The smal 1 sample size makes it difficult to distinguish between finished tools and fortuitously beveled tools.

DB3:1. Form 1 - "Convex Beveled" (4 specimens; Fig. $28, i, j$ )

Group 3. Form 1 contains four fragmentary bifaces that have a beveled end. When viewed from the end, these bifaces have a slightly curved, convex (ventral surface down) beveled edge. Two specimens are thick bifaces, and two are thin bifaces. This category was initial1y set up during artifact distribution coding. A final reexamination of the category reveals that these otherwise dissimilar artifacts were probably beveled to set up flake platforms during bifacial thinning. A 11 specimens appear to be bifacial fragments broken during the reduction process.

DB3:2. Form 2 - "Shovel-Bit" (2 specimens)

Form 2 specimens, in contrast to Form 1, appear to be functional tools. Both artifacts have narrows rounded proximal ends and widely expanding distal ends that have flat, unmodified planar facets on the ventral surface adjacent to the distal end. Both specimens appear to have been made from large secondary or primary flakes; the above-mentioned flat facets appear to be the distal part of the ventral surface of the original flake. Both specimens have cortex patches which cover the central portion of the dorsal surface. In 
other morphological aspects these two specimens differ and deserve individual description. Table 17 provides metric data for Group 3, Form 2 specimens.

Specimen 1 (Fig. 28, $1,1^{\circ}$ ): Specimen 1 has a roughly triangular out 1 ine; the lateral edges are 51 ightly concave, and the distal edge is slightly convex. The wide distal end is modified on $7 y$ by a narrow band of marginal trimming on the ventral surface. The proximal two-thirds of the artifact is bifacially flaked; if it were broken off, the remaining distal one-third would be classified as a trimmed flake. A smal1, heavily patinated patch is present on the proximal end. The function of this unusual artifact is unknown. No comparable specimens could be located in regional 1 iterature. Two very similar (one virtually identical) specimens were observed in the former 1 andowner's collection (Ganahl Walker, J r.). He did not remember picking them up but had collected many artifacts eroding from along the bluff at $41 \mathrm{BX} 228$. Based strictly on morphological appearance, it is tentatively suggested that this specimen may represent a hafted scraping tool.

Specimen 2 (Fig. 28,k): This artifact has a wide, convex distal end and slightly concave 1 ateral edges which converge to form a bluntly pointed proximal end. The convex distal end has been evenly shaped by unifacial flaking on the ventral surface. The distal edge has an edge angle of approximately $50^{\circ}$. The proximal half of the tool is bifacially flaked. A cortex patch covers the proximal end and may represent the platform of the original flake. Once again, comparable specimens could not be found, and the function of this specimen is unknown. The distal end of the tool strongly resembles a wide end scraper. Perhaps this artifact did function as a hafted scraper.

DB3:3. Form 3 - "Rectangular" (5 specimens; Fig. 28,m)

The five Group 3. Form 3 artifacts are broken bifaces with a squared-off beveled end and parallel lateral edges. One specimen is a thick biface; the remaining four are thin bifaces. Form 3 artifacts, 1 ike Form 1 , are most likely beveled as a step during bifacial thinning and, thus, should not be considered "distally beveled tools." The reader is again cautioned that end beveling can indicate a manufacturing technique as we 11 as a functional tool type.

\section{DB4. Group 4 - Preforms and Proximal Fragments (10 specimens)}

DB4:1. Form 1 - Preforms (4 specimens)

Group 4, Form 1 artifacts are thick bifaces with morphological characteristics suggestive of distally beveled tool preforms or unfinished tools. Upon final examination, two specimens appear to be unfinished Group 1 tools. The remaining two artifacts are probably just broken thick bifaces that bear a fortuitous resemb 1 ance to distally beveled tool morphologies. Since neither of the first two specimens were found in association with finished Group I specimens or any other distally beveled tool, this category is of little research value. 
TABLE 17. DISTALLY BEVELED TOOLS, GROUP 3, FOPM 2, METRIC ATTRIEUTE DATA

\begin{tabular}{ccccccc}
$\begin{array}{c}\text { Specimen } \\
\text { Number }\end{array}$ & $\begin{array}{c}\text { Lot } \\
\text { Number }\end{array}$ & $\begin{array}{c}\text { Length } \\
(\mathrm{mm})\end{array}$ & $\begin{array}{c}\text { Width* } \\
(\mathrm{mm})\end{array}$ & $\begin{array}{c}\text { Thickness } \\
(\mathrm{mm})\end{array}$ & $\begin{array}{c}\text { Weight } \\
(\mathrm{g})\end{array}$ & Figure \\
\hline 1 & 367 & 8.1 & 6.8 & 1.9 & 74.8 & $28,1,1^{\prime}$ \\
2 & 388 & 6.9 & 5.2 & 1.5 & 47.5 & $28, \mathrm{k}$
\end{tabular}

* Width = maximum width = distal width.

\section{DB4:2. Form 2 - Proximal Eragments (6 specimens)}

Group 4, Form 2 specimens are pointed thick biface fragments similar to the proximal ends of $D B 2: 1$ tools. The stratigraphic position of several of these fragments suggests that this interpretation could be correct. These specimens could also be various thick biface distal fragments. Hence, this category is also of 1 ittle research value.

\section{Perforators (P) (35 specimens)}

The bifacially worked artifacts in this grouping are recognized morphologically as perforators. They characteristically have long slender projections forming the distal end and noticeably wider proximal ends or bases. They have also been referred to in the regional 1 iterature as drills, aw $1 \mathrm{~s}$, borers, etc. They apparently functioned to pierce, punch, or bore holes, a though without careful wear pattern studies the exact use cannot be determined. Perforators at 41 BX 228 appear to be most often made on dart points or other bifaces.

The distal projection or bit varies considerably in size and shape. Many specimens have a relatively long, narrow, thick bit ( $F i g, 33, a)$, while others have a relatively short, wide, thin bit (Fig. 33,b). This may indicate functional differences, such as borers versus piercers. While most perforators appear finely worked, some are massive and crudely chipped (Fig. 33,g). Approximately 50\% of the perforators appear heat treated. No microscopic wear study of these artifacts was attempted, however, macroscopic examination suggests some specimens have heavily worn or dulled bit edges that appear related to use.

Metric measurements of perforators present somewhat of a problem. Standard measurements are provided for the overall artifact. Separate measurements are given for the bit. Bit length is defined as that measurement between the distal tip and the approximate point on the tool where a noticeable increase in width occurs as the base flares outward. The bitwidth is also taken at this point. The bit thickness is the maximum thickness anywhere between this 